PROGRAMA DE PÓS-GRADUAÇÃO EM INTEGRAÇÃO DA AMÉRICA LATINA DA UNIVERSIDADE DE SÃO PAULO - PROLAM/USP

\title{
KARINA FORTETE
}

De trabalhador a empreendedor: uma análise das formas de produção e reprodução da força de trabalho no Brasil e no Equador.

Dissertação de Mestrado apresentada para obtenção do titulo de Mestre no Programa de Pós-Graduacão em Integração da América Latina da Universidade São Paulo - PROLAM/USP.

Orientadora: Profa. Dra. Lúcia Emília Nuevo Barreto Bruno

São Paulo

2012 


\section{FOLHA DE APROVAÇÃO}

"De trabalhador a empreendedor: uma análise das formas de produção e reprodução da força de trabalho no Brasil e no Equador".

Dissertação de Mestrado apresentada para obtenção do titulo de Mestre no Programa de Pós-Graduacão em Integração da América Latina da Universidade São Paulo - PROLAM/USP.

Orientadora: Profa. Dra. Lúcia Emília Nuevo Barreto Bruno

APROVADO EM:

\section{BANCA EXAMINADORA}

Profa. Dra. Lúcia Emília Nuevo Barreto Bruno.

Faculdade de Educação . Universidade de São Paulo

Profa. Dra. Doris Accioly e Silva.

Faculdade de Educação.

Universidade de São Paulo
Prof. Dr. Henrique Tahan Novaes.

Faculdade de Filosofia e Ciências. Universidade Estadual Paulista Júlio de Mesquita Filho - UNESP- Marília. 


\section{AGRADECIMENTOS}

Em primeiro lugar, gostaria de agradecer à Lúcia Bruno, pelas orientações assertivas e pela cota de entusiasmo colocada sempre que eu surgia com novas ideias. Obrigada por me acompanhar nessa caminhada!

Agradeço à CAPES, pelo apoio financeiro para a realização desta pesquisa e especialmente, aos leitores e aos revisores deste trabalho, pela disposição e colaboração.

Finalmente, dedico este trabalho aos latino-americanos que, como eu, acreditam na unidade de uma América que é diferente por natureza, mas que pode ser semelhante por opção. 


\section{RESUMO}

FORTETE, K. De trabalhador a empreendedor: uma análise das formas de produção e reprodução da força de trabalho no Brasil e no Equador. 2012. 192f. Dissertação (Mestrado) - Programa de Pós-Graduação em Integração da América Latina, Universidade de São Paulo, São Paulo, 2012.

O presente trabalho tem como objetivo analisar duas práticas de economia solidárias que ocorrem na América Latina e sua vinculação com as atuais estratégias de produção e reprodução da força de trabalho. As experiências escolhidas foram o "Banco Palmas", localizado na cidade de Fortaleza, no estado do Ceará, Brasil, e a organização da sociedade civil CEPESIU, com seu programa "Sociedades Populares de Inversión", localizada em Quito, no Equador. Para isso, foi realizada uma retrospectiva histórica das diferentes formas de produção e reprodução da força de trabalho, assim como das formas de governo que sustentaram cada uma delas, desde o período imediatamente seguinte à Revolução Industrial até a atualidade. Este percurso oferece elementos que constatam a hipótese inicial de que as práticas chamadas, genericamente, de "economia solidária" representam a mais nova (e aceita) forma de produção e reprodução da força de trabalho no cenário neoliberal. No decorrer do trabalho, analisam-se os papeis que assumem os diversos agentes envolvidos em cada momento histórico estudado, dando destaque para a atuação do Estado e suas estratégias de intervenção em ambos os países observados.

Palavras-chave: produção e reprodução da força de trabalho; economia solidária, bancos comunitários de desenvolvimento. 


\section{RESUMEN}

FORTETE, K. "De trabajador a emprendedor: un análisis de las formas de producción y reproducción de la fuerza de trabajo en Brasil y Ecuador". 2012. 192f. Disertación (Maestría) - Posgrado en el Programa Integración de América Latina, Universidad de São Paulo, São Paulo, 2012

El presente trabajo tiene como objetivo analizar dos prácticas de economía solidaria realizadas en América Latina y su vinculación con las actuales estrategias de producción y reproducción de la fuerza de trabajo. Las prácticas elegidas fueran el "Banco Palmas" localizado en la ciudad de Fortaleza, en el estado de Ceará, Brasil y la organización de la sociedad civil CEPESIU, con su programa "Sociedades Populares de Inversión", localizada en Quito, en Ecuador. Para eso, fue realizada una retrospectiva histórica de las diferentes formas de producción y reproducción de la fuerza de trabajo así como de las formas de gobierno que sustentan cada una de ellas, desde el período inmediatamente siguiente a la Revolución Industrial hasta la actualidad. El camino realizado ofrece elementos que constatan la hipótesis inicial, de que las prácticas llamadas, genéricamente, de "economía solidaria" representan la más nueva (y aceptada) forma de producción y reproducción de la fuerza de trabajo, en el escenarios neoliberal. En el transcurso del trabajo, se analiza el papel que asumen los diversos agentes involucrados, de acuerdo al momento histórico identificado, dando destaque para el papel del Estado y sus estrategias de intervención en ambos países seleccionados para el estudio.

Palabras claves: producción y reproducción de la fuerza de trabajo, economía solidaria, bancos comunitarios de desarrollo. 


\section{SUMÁRIO}

Introdução 10

CAPÍTULO I PRODUÇÃO E REPRODUÇÃO DA FORÇA DE TRABALHO A PARTIR DA REVOLUÇÃO INDUSTRIAL: UMA VISÃO HISTÓRICA.

1. AS ESTRATÉGIAS DO CAPITAL: A REVOLUÇÃO INDUSTRIAL E OS RITOS DE PASSAGEM................................................................................ 13

2 AS ESTRATÉGIAS DOS TRABALHADORES: O MOVIMENTO OPERÁRIO EUROPEU E SUAS MANIFESTAÇÕES …….......................................... 17

2.1 As Associações de ajuda mútua .......................................................... 19

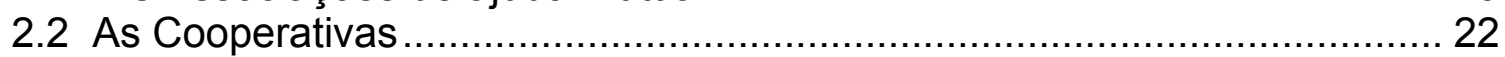

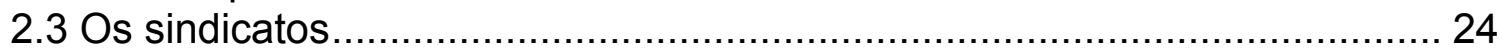

3. O SURGIMENTO DO MOVIMENTO OPERÁRIO NO CONTEXTO LATINOAMERICANO E SUAS MANIFESTAÇÕES NO BRASIL E NO EQUADOR .......... 28 4. O PAPEL CENTRAL DO ESTADO NA PRODUÇÃO E REPRODUÇÃO DA

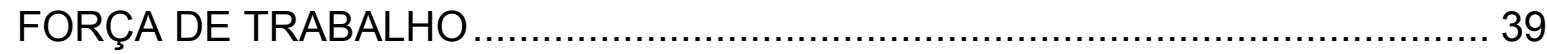

4.2 Na América Latina: Sistema de proteção social baseado no trabalho......... 45

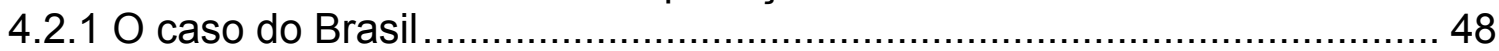

4.2.2 O caso do Equador .................................................................... 52

CAPITULO II PRODUÇÃO E REPRODUÇÃO DA FORÇA DE TRABALHO NA ERA NEOLIBERAL: O QUE PERMANECE E O QUE MUDA.

1.AS NOVAS DETERMINAÇÕES DO MUNDO DO TRABALHO .... 60

2. A INTERVENÇÃO DO ESTADO E O NOVO ENFOQUE DAS POLÍTICAS PÚBLICAS NA AMÉRICA LATINA

2.1 A focalização e o sentido público do ser social.......................................... 64

2.2 Da responsabilidade estatal à responsabilidade partilhada .........................6 68

2.2.1 O papel das organizações internacionais ............................................... 68

2.2.2 O papel das corporações empresariais ................................................ 71

2.2.3 O papel das organizações da sociedade civil ...................................... 73

2.2.4 O papel da Comunidade local......................................................... 78

3. A INTERVENÇÃO DO ESTADO E O NOVO ENFOQUE DAS POLÍTICAS

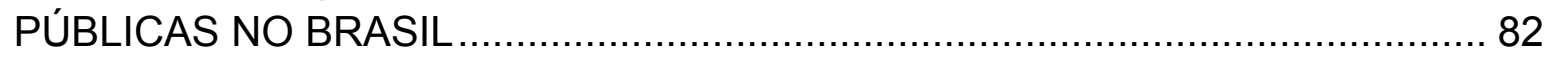

4.A INTERVENÇÃO DO ESTADO E O NOVO ENFOQUE DAS POLÍTICAS PÚBLICAS NO EQUADOR

CAPITULO III AMÉRICA LATINA ECONOMICAMENTE SOLIDÁRIA: NOVAS FORMAS DE PRODUÇÃO E REPRODUÇÃO DA FORÇA DE TRABALHO? ....... 93

1.ECONOMIA SOLIDÁRIA: PARA UMA GENEALOGIA DO CONCEITO .93

2. POLÍTICAS PÚBLICAS DE ECONOMIA SOLIDÁRIA: METAMORFOSE DA RELAÇÃO CAPITAL - TRABALHO?.

2.1 A Economia Solidária No Brasil 
2.2 A Economia Solidária No Equador.

3. FINANÇAS SOLIDÁRIAS E BANCOS COMUNITÁRIOS DE

DESENVOLVIMENTO NA AMÉRICA LATINA ........................................... 114

3.1 Influência que vem da Ásia

3.2 Influência que vem dos Estados Unidos

CAPÍTULO IV EXPERIÊNCIAS DE FINANÇAS SOLIDÁRIAS NO BRASIL E NO EQUADOR: A REPRODUÇÃO NA PRÁTICA

1.“SOMOS POBRES PORQUE NÃO TEMOS DINHEIRO”: A HISTÓRIA DO BANCO PALMAS

1.1 Os gestores do Banco Palmas............................................................ 129

1.1.1 Para um banco, um banqueiro ................................................. 129

1.1.2 Uma andorinha só não faz verão ................................................... 130

1.2 Principais linhas de atuação do Banco Palmas ....................................... 131

1.2.1 Sistema integrado de microcréditos ............................................... 132

1.2.2 Empreendimentos produtivos solidários .......................................... 135

1.2.3 Microsseguro Palmas................................................................... 136

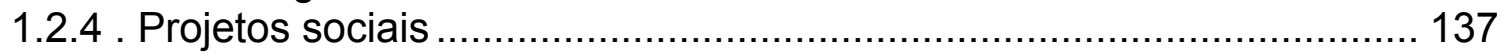

1.3. Pagar com outra moeda............................................................ 138

1.4 A experiência que transcendeu o Conjunto Palmeira: o Instituto Palmas 141

2. NO EQUADOR: A CEPESIU E AS SOCIEDADES POPULARES DE

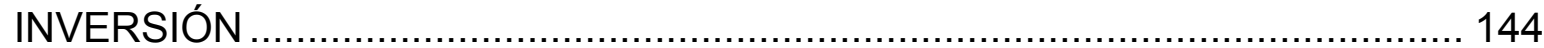

2.1 Principais programas desenvolvidos pelo CEPESIU ............................ 146

2.2 A gestão do CEPESIU ............................................................. 152

2.3. As sociedades populares de inversión................................................ 152

2.3.1 Consórcios de SPI ...................................................................... 155

3. O QUE APROXIMA E O QUE DISTANCIA AS EXPERIENNCIAS ANALISADAS

4. ECONOMIA SOLIDÁRIA, ECONOMIA DOS GESTORES? .......................... 160

5. SER SOLIDÁRIO: COISA DO DESTINO? ................................................ 163

6. SER EMPREENDEDOR: OPÇÃO OU IMPOSIÇÃO? .................................. 165 


\section{LISTA DE ABREVIATURAS}

ADS - Agencia de Desenvolvimento Solidário.

ANTEAG - Associação Nacional de Trabalhadores em Empresas de Auto-gestão e Co-gestão.

ASMOCONP - Associação dos Moradores do Conjunto Palmeira.

BB - Banco do Brasil.

BCD - Bancos Comunitários de Desenvolvimento.

BID - Banco Interamericano de Desenvolvimento.

BPB - Banco Popular do Brasil.

CESPROE - Centro de Servicios Productivos para la Ebanistería.

CIRE - Coordenação e Iniciativas para Refugiados e Estrangeiros da Bélgica.

COB - Congresso Operário Brasileiro.

COG - Confederación Obrera del Guayas.

CTE - Confederación de Trabajadores del Ecuador.

CEOSL - Confederación Ecuatoriana de Organizaciones Sindicales Libres.

CEDOC - Confederación Ecuatoriana de Obreros Católicos.

CGT - Central Geral dos Trabalhadores.

CUT - Central Única dos trabalhadores.

DEL - Programa de Fomento do Desenvolvimento Econômico Local.

ECOSOL - Cooperativa Central de Crédito e Economia Solidária.

FAPAG - Fundo de Apoio a Projetos de Autogestão.

FBES - Fórum Brasileiro de Economia Solidária.

FINCA - Fundação para a Assistência Comunitária internacional.

GTZ - Sociedade Alemã de Cooperação Técnica.

FOGAL - Fondo de Garantía Latinoamericana.

HIAS - Hebrean Inmigrant Aid Society.

IEPS - Instituto Nacional de Economia Popular y Solidária.

MIES - Ministério de Inclusión Económica y Social.

MTE - Ministério de Trabalho e Emprego.

OEP - Organizações econômicas populares.

OIT - Organização Internacional do Trabalho. 
ONG - Organização não governamental.

ONU - Organização das Nações Unidas.

OSC - Organização da Sociedade Civil.

PCA - Programa de Crédito Autoadministrado.

PCD - Programa de Crédito Direto.

$\mathrm{PCl}$ - Programa de Crédito Individual.

PGS - Programa de Grupos Solidários.

PNMPO - Programa Nacional de Microcrédito Produtivo Orientado.

PNUMA - Programa das Nações Unidas para o Meio Ambiente.

PROGER - Programa de Geração de Emprego e Renda.

SACC- Sistemas autogestionados de crédito comunal.

SDTS - Secretaria do Desenvolvimento, Trabalho e Solidariedade.

SEDAI - Secretaria do Desenvolvimento e dos Assuntos Institucionais.

SENAES - Secretaria Nacional de Economia Solidária.

SINE - Sistema Nacional de Emprego.

SPI - Sociedades Populares de Inversión.

UEPE - Unidades Econômicas de Pequena Escala.

UNDOC - United Nations Office on Drugs and Crime.

UNESCO - Organização das Nações Unidas para a educação.

UNICEF - United Nations Children's Fund.

UNISOL - Central de Cooperativas e Empreendimentos Solidários.

USAID- United States Agency for International Development. 


\section{INTRODUÇÃO}

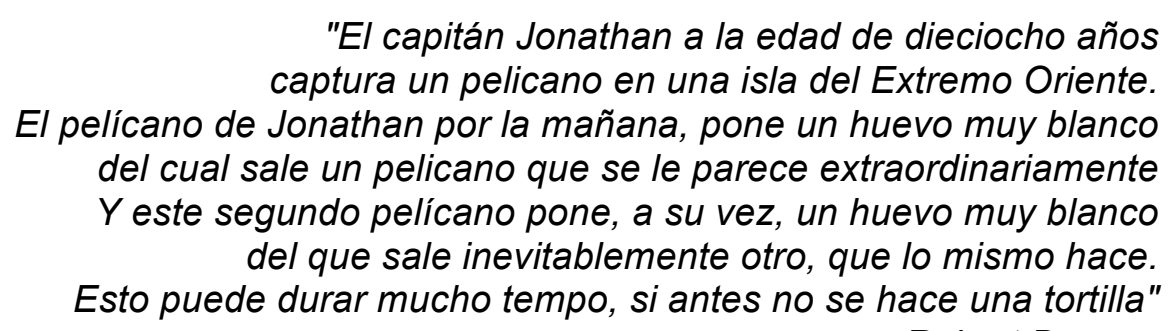

Robert Desnos

A Dissertação de Mestrado intitulada "De trabalhador a empreendedor: uma análise das formas de produção e reprodução da força de trabalho no Brasil e no Equador" se enquadra no Programa de Integração da América Latina da Universidade de São Paulo (PROLAM-USP) durante o período de março de 2010 até fevereiro de 2011. Tem como objetivo analisar duas experiências de economia solidária que ocorrem na América Latina e sua vinculação com as atuais estratégias de produção e reprodução da força de trabalho. As práticas escolhidas foram o "Banco Palmas" de Fortaleza, no Brasil, e a organização da sociedade civil CEPESIU, com seu programa "Sociedades Populares de Inversión", localizada em Quito, no Equador.

A pesquisa está orientada na hipótese de que as práticas genericamente chamadas de economia solidária constituem novas estratégias do capital para garantir a produção e reprodução da classe trabalhadora e para isso, serão necessárias novas formas de governo, no sentido que Foucault confere a esse termino nos seus últimos trabalhos publicados ${ }^{1}$.

A metodologia utilizada foi a pesquisa exploratória bibliográfica de dados secundários, tais como teses, artigos, entrevistas e livros que abordam o tema, especialmente as que dão ênfase às experiências latino-americanas e as que internacionalmente trouxeram elementos para a reflexão. Além disto, foram utilizados trabalhos elaborados pelas próprias organizações escolhidas, já que mesmo sendo um assunto novo e de pouca difusão, os gestores têm investido na sistematização de suas práticas, o que permitiu acesso a esse tipo de material.

Elaborados o objetivo e a hipótese, e definida a metodologia da pesquisa, buscou-se fazer uma retrospectiva histórica que oferecesse elementos para identificar

\footnotetext{
${ }^{1}$ Faz-se referência aos livros "Nascimento da biopolítica" (2008) e "Segurança, território e população (2008)"
} 
se há conexão entre as novas e as antigas formas de produção e reprodução da força de trabalho e, em casso positivo, como esses fatos se relacionam.

Para tanto, o trabalho foi dividido em quatro capítulos, além da introdução e das considerações finais. No primeiro, analisam-se as mudanças na organização da produção desde a Revolução Industrial e as formas que adquirem à medida que o capitalismo avança. Assim, abordam-se as estratégias empregadas pelo capital e as que são levadas a cabo pelo movimento operário em nome dos trabalhadores para sobreviver no novo sistema. São abordados neste caso o papel das organizações de ajuda mútua, as cooperativas e os sindicatos na Europa e na América Latina, destinando principal atenção para o caso do Brasil e do Equador.

Em seguida, busca-se mostrar como o Estado, a partir da década de 1930, adota um papel central no processo de produção e reprodução da força de trabalho. Na Europa, por meio de implementação do Estado de Bem-Estar Social e na América Latina, através de um processo repleto de incongruências, associando diretamente o bem-estar com a condição laboral dos trabalhadores.

No segundo capítulo, são descritas e analisadas as novas manifestações da questão social frente ao surgimento e desenvolvimento do neoliberalismo. Destacamse as principais mudanças referentes ao mundo do trabalho e às suas manifestações decorrentes da transição de uma sociedade industrial para uma sociedade moderna. Para isso, são mencionadas as principais características adotadas pelas políticas sociais na América Latina dos últimos 20 anos, assim como os agentes envolvidos e os diversos fatores que influenciaram o tipo de intervenção adotada pelos Estados latino-americanos. Também este capítulo aprofunda-se nas particularidades dos casos brasileiro e equatoriano.

Com o embasamento oferecido pelos dois capítulos anteriores, no terceiro é analisada a vinculação entre as novas formas que o neoliberalismo adquire para (des)atender a questão social e a emergência da economia solidária neste contexto. Um contexto de crise das relações de trabalho e ao mesmo tempo de ressurgimento de formas associativas e colaborativas, já existentes no século XVIII, porém guardadas no baú por dois séculos. Mostra-se também o contexto sócio-político da América Latina, em especial referentes ao Brasil e ao Equador, no qual as práticas escolhidas surgem e se desenvolvem.

No quarto capítulo, faz-se uma análise das duas iniciativas de Economia Solidária, objeto deste estudo, os Bancos Comunitários de Desenvolvimento de 
ambos os países pesquisados. Além de sua descrição e caracterização, são comparadas em suas principais dimensões, destacando elementos que aproximam e outros que diferenciam ambas as experiências.

No mesmo sentido, três perguntas contribuirão para sintetizar a análise: "Economia solidária, economia dos gestores?", "Ser solidário: coisa do destino?”; e por último: "Ser empreendedor: opção ou imposição?"

Finalmente, poderão ser lidas as considerações finais feitas a partir da apreciação minuciosa e crítica, que apoiada nos elementos que a história oferece, convidam o leitor a pensar no que há por trás dessas novas e sedutoras formas de gerar emprego e renda, quando estas, muitas vezes, se tornaram meras estratégias de cooptação e controle, que despolitizam e aplacam os trabalhadores, suas lutas e reivindicações.

Com esta consciência, quem sabe não possam se utilizar os ovos do pelicano para, finalmente, fazer uma "tortilla". 


\section{CAPÍTULO I}

\section{PRODUÇÃO E REPRODUÇÃO DA FORÇA DE TRABALHO A PARTIR DA REVOLUÇÃO INDUSTRIAL: UMA VISÃO HISTÓRICA}

No decorrer do capítulo, atenta-se para as principais mudanças relacionadas às formas de organização da produção, a divisão do trabalho e as relações de trabalho, à medida que o capitalismo avança, bem como a influência destes processos no desenvolvimento da força de trabalho.

Para isso, abordam-se alguns fatos que ocorreram no período de 1800 a 1990, os quais marcam a passagem de uma fase primitiva na qual o capital crescia subordinado à pequena produção mercantil, para uma fase em que o capitalismo cria uma nova forma de produção que separa definitivamente o operário dos meios de produção.

Com isto, os mecanismos de produção e reprodução da força de trabalho sofreram mudanças significativas no decorrer da história, segundo os modelos econômicos imperantes em cada época. Aos efeitos deste trabalho, destacam-se as transformações que apareceram a partir da Revolução Industrial, iniciada na Inglaterra, por entender que foi o momento em que se alteraram drasticamente as condições de existência da população humana, impondo, ao dizer de Coggiola "um ritmo geométrico de crescimento, que superou o ritmo aritmético que tinha seguido em toda a história precedente" convertendo-se na "grande ruptura da história humana" (2007, p. 2)

\section{AS ESTRATÉGIAS DO CAPITAL: A REVOLUÇÃO INDUSTRIAL E OS RITOS DE PASSAGEM}

A Revolução Industrial teve seu ápice e sua manifestação mais aperfeiçoada na Inglaterra, e foi difundida pelo resto do mundo durante as décadas posteriores. No século XIX, foi disseminada pela Europa Ocidental e a América do Norte, e mais tarde, progredindo lentamente nos países da Europa Central e Meridional, China e América Latina, fazendo com que a constante revolução dos meios de produção se 
transformara na norma geral do desenvolvimento histórico e econômico (MARX, 1952; COGGIOLA, 2010).

Assim, com o advento da vida moderna, nasce uma nova concepção de trabalho. Segundo Hanna Arendt, a modernidade trouxe a glorificação teórica do trabalho, transformando toda a sociedade em uma sociedade do trabalho (ARENDT, 1993).

De acordo com Marx, esta nova forma de conceber o trabalho iniciou-se a partir do momento que a produção é feita predominantemente para o mercado, convertendo o trabalho em valor de troca. Com o desenvolvimento do capitalismo, a força de trabalho assume - desde uma perspectiva marxista - caráter de mercadoria, forçando as pessoas a venderem parte de suas vidas, como a mercadoria força de trabalho, a fim de sobreviver e ter certo acesso à riqueza social, sendo forçadas a trabalhar para não passar fome (CLEAVER, 1981).

A introdução de máquinas multiplicou o rendimento do trabalho e aumentou espetacularmente a produção global, onde a renda adquire um valor fundamental. Como afirma Coggiola, na década de 1780

pela primeira vez na história da humanidade, foram retirados os grilhões do poder produtivo das sociedades humanas, que daí em diante se tornaram capazes da multiplicação rápida, constante, e ilimitada, de homens, mercadorias e serviços (COGGIOLA, 2007, p. 2).

Com estas mudanças ocupando a cena econômica, o papel da força de trabalho também muda, pois, o capitalismo só existe e perdura no tempo porque há uma classe que tem o controle total dos meios de produção e outra que é controlada por eles, que sobrevive em troca de disponibilizar sua força de trabalho, eixo amplamente desenvolvido inicialmente por Marx e por diversos pensadores que lhe seguiram.

Segundo essa lógica, a reprodução do capital envolve a reprodução da força de trabalho e engendra relações de poder altamente desiguais, pois enquanto o capitalista procura estratégias para obter mais-valia, o trabalhador faz o mesmo esforço para valorizar sua força de trabalho de forma que possa cobrir suas necessidades humanas, necessidades estas que são criadas pelo próprio sistema. De acordo com Cleaver, "O poder que tem o capital de impor a forma de mercadoria é o poder de manter o próprio sistema - um sistema no qual a vida para a maioria das pessoas é transformada em força de trabalho" (CLEAVER, 1981, p. 90). Assim, 
a produção da força de trabalho consiste basicamente na satisfação das necessidades essenciais por parte do operário, sem a qual não poderia se apresentar cada dia para trabalhar.

Desde a ótica capitalista, ao reproduzir a si mesmo, o operário se reproduz para o capital. Segundo Marx, todo processo social de produção é, ao mesmo tempo, um processo de reprodução. "La producción capitalista [...] produce no sólo mercancías, no sólo plusvalor, sino que también produce y reproduce la relación capitalista: por un lado el capitalista, por el otro, el trabajador asalariado"2 (MARX, 1952, p. 531-532).

Trata-se de um trabalhador que deve necessariamente existir para produzir riqueza, de forma em que para aumentar o capital, deve haver aumento da força de trabalho. Assim, nasce o que Coggiola chama de 'nova classe de escravos', o proletariado, explicando em uma passagem que:

A mecanização da produção criou o proletariado rural e urbano,
composto de homens, mulheres e crianças, submetido a um trabalho
diário exaustivo, no campo ou nas fábricas. Surgiam, como figuras
dominantes da vida econômica (produção) o capital industrial e o
trabalho assalariado. A Revolução Industrial encerrou a transição
entre feudalismo e capitalismo, a fase de acumulação primitiva de
capitais e de preponderância do capital mercantil sobre a produção.
Completou ainda o movimento da revolução burguesa iniciada na
Inglaterra no século XVII (COGGIOLA, 2010).

Nesse sentido, o capitalismo traz uma nova forma de "ser operário", ou seja, traz um proletariado assalariado, que por meio do seu salário pode formar parte não só do grupo que produz, mas também do grupo que consome, contribuindo duplamente, para o enriquecimento da classe dona dos meios de produção.

A classe operária se define historicamente pela sua relação com a matéria (LOJKINE, 1990) de forma em que ao aumentar o capital, aumenta também a massa de trabalhadores pobres e disciplinados, "cuya fuerza de trabajo se convierte en creciente fuerza de explotación al servicio del creciente capital, lo que les obliga a eternizar su supeditación al propio producto de su trabajo, personificado en el capitalista"3 (MARX, 1952, p. 519- 520). Desta forma, os capitalistas não adquirem

\footnotetext{
${ }^{2}$ Tradução livre da pesquisadora - A produção capitalista produz não só mercadorias, não só mais-valia, senão também produz e reproduz a relação capitalista: por um lado o capitalista, por outro, o trabalhador assalariado.

${ }^{3}$ Tradução livre da pesquisadora - Cuja força de trabalho se converte em crescente força de exploração ao serviço do crescente capital, o que lhe obriga a eternizar sua subordinação ao próprio produto de seu trabalho, personificado no capitalista.
} 
apenas o resultado do trabalho, mas fundamentalmente o direito ao uso da força do trabalho, administrando o processo produtivo (BERNARDO, 1991).

Com o avanço do capitalismo, isto é possível porque existe um número de trabalhadores disponíveis, ao qual Marx chamou de exército industrial de reserva, que permite a utilização (e também a exploração) da força de trabalho. De acordo com Marx, a acumulação capitalista "produce constantemente, en proporción a su intensidad y a su extensión, una población obrera excesiva para las necesidades medias de explotación del capital, es decir, una población obrera remanente y sobrante" ${ }^{4}$ (MARX, 1952, p. 533). Conforme cresce a força produtiva do trabalho, o capital faz crescer sua oferta de trabalho mais rapidamente que sua demanda de operários, e desta forma tem condições de criar um grupo de inativos que aguardam para fazer parte do 'exército dos ativos'. Diante disto, é possível compreender que "la producción de una población sobrante relativa (...) sobrante con relación a las necesidades medias de explotación del capital, es condición de vida de la industria moderna" ${ }^{5}$ (Ibidem, p. 536).

É importante mencionar que, após superado o primeiro período do capitalismo, nenhum período histórico seguinte prescindiu deste exército industrial de reserva; pelo contrário, o número de operários que engrossavam as filas de desempregados não fez mais que crescer, seguida de uma acumulação cada vez mais acelerada do capital. O mercado laboral funciona no quadro de um exército industrial de reserva cujo tamanho aumenta ou diminui segundo as necessidades da acumulação capitalista, porém nunca será absorvido completamente. Isto pode ser observado claramente quando analisada a década de 1950, com o aumento do desemprego, produto da grande depressão e das recessões, mas também - e principalmente - a partir da década de 1980, onde o desemprego estrutural alcançou seus níveis mais elevados.

As transformações técnicas dos processos de produção influenciaram diretamente o regime dos salários do setor operário, respondendo à lei de oferta e demanda: quanto maior a oferta, menor o preço. No caso dos trabalhadores, funciona da mesma forma, quanto maior o número de trabalhadores disponíveis,

\footnotetext{
${ }^{4}$ Tradução livre da pesquisadora - Produz constantemente em proporção à sua intensidade e à sua extensão uma população operária excessiva para as necessidades médias de exploração do capital, isto é, uma população operária remanescente e excedente.

${ }^{5}$ Tradução livre da pesquisadora - A produção da população excedente relativa (...) excedente com relação às necessidades médias de exploração do capital, é condição de vida da indústria moderna
} 
menor o preço pago pelo seu trabalho e maior deve ser seu esforço para se manter nessa condição, submetidos às imposições do capital. Havendo um exército de reserva, os operários podem ser pagos apenas segundo conveniência dos donos do capital e o resultado no início não será a revolta, e sim a submissão, através de um sistema no qual o capitalista poderá explorar as forças de trabalho individuais, comprando mais força de trabalho com o mesmo capital. De acordo com Marx:

De una parte, conforme progresa la acumulación, a mayor capital variable se pone en juego más trabajo, sin necesidad de adquirir más obreros; de otra parte, el mismo volumen de capital variable hace que la misma fuerza de trabajo despliegue mayor trabajo $\mathrm{y}$, finalmente moviliza una cantidad mayor de fuerzas de trabajo inferiores, eliminado las más perfectas ${ }^{6}$ (MARX, 1952, p. 538)

Desta forma, o exército industrial de reserva possibilita a grande vitória da indústria: a disponibilidade imediata de uma enorme quantidade de mão-de-obra, a qual, em princípio, poderia ser utilizada como os donos dos meios de produção bem entenderem.

Por fim, é importante ressaltar que o capitalismo teve distintas manifestações na Europa e na América Latina. Os processos de industrialização aconteceram em períodos diferentes, porém na América Latina foram absolutamente influenciados pelos países centrais. Levando em conta esta diferenciação, mas também - e principalmente - esta relação, o texto aborda as estratégias utilizadas pelos trabalhadores no processo de produção e reprodução da força de trabalho primeiro na Europa, e logo no Brasil e Equador. Do mesmo modo, abordam-se as estratégias utilizadas pelo Estado nas três regiões, fundamentalmente na segunda metade do século XX, até a década de 1990, quando se observam as novas grandes mutações da questão estudada.

\section{AS ESTRATÉGIAS DOS TRABALHADORES: O MOVIMENTO OPERÁRIO EUROPEU E SUAS MANIFESTAÇÕES}

As mudanças radicais nos modos de produção trouxeram uma também radical mudança da vida humana, criando um trabalhador 'livre', os camponeses

\footnotetext{
${ }^{6}$ Tradução livre da pesquisadora - Por um lado, conforme avança a acumulação, maior o capital variável que está em jogo, mais trabalho, sem necessidade de adquirir mais operários, por outro lado, a mesma quantidade de capital variável faz que a mesma força de trabalho desenvolva maior trabalho e finalmente mobiliza uma quantidade maior de forças de trabalho inferiores, eliminando as mais perfeitas.
} 
expropriados, que saem do campo para se radicar na cidade, sem propriedade e desligados da autoridade de um senhor; prontos para se tornarem mão de obra industrial (COGGIOLA, 2010). Possuíam uma única riqueza: sua força de trabalho, que seria trocada por baixos salários e logo não distinguiria entre homens, mulheres e crianças, pois todos formavam parte do exército industrial de reserva, antes mencionado. Desta forma, a força de trabalho garante a sua sobrevivência e também a sua reprodução. Exemplo disto é o aumento da população na Inglaterra, a que passou de 8,5 milhões em 1780 para 36 milhões no período de 100 anos (HOBSBAWM, 1983; COGGIOLA, 2010).

O ritmo de trabalho da fábrica era muito diferente do ritmo que os artesãos e pequenos produtores agrários possuíam, pelo qual o processo de industrialização (e a disciplina fabril) exigiu uma nova forma de viver, desta vez, de acordo com as novas necessidades da produção. Isto significou extensas jornadas de trabalho, horários de entrada e saída, sem feriados ou férias, e curtos períodos de descanso.

Segundo Bertaux,

Durante toda a primeira Revolução Industrial, a exploração da população operária foi feita de forma inteiramente selvagem. As condições de reprodução (da população operária) eram aleatórias. $O$ fluxo constante de camponeses desenraizados vinha substituir uma mão-de-obra que definhava (...) no começo da Revolução Industrial, os filhos dos operários morriam em massa (BERTAUX, 1979, p. 89).

Estas estratégias de dominação utilizadas pelo capital impulsionaram a organização da classe operária que, a partir da metade do século XIX, se agrupou em organizações de classe, com o objetivo de melhorar suas condições laborais e salariais.

A primeira grande influência veio do anarquismo, ideologia que surge na Europa da primeira metade do século XIX, fundamentalmente na França, com Proudhon, mas também com Godwin, na Inglaterra, e Stirner, na Alemanha. Assim, na década de 50 , se relaciona com os movimentos de ajuda mútua, como será visto a continuação e, posteriormente, na década de 1860, vincula sua atividade principalmente durante a Primeira Internacional, a qual domina por muito tempo, já que a maior parte dos operários europeus, eram anarquistas (RAMA E CAPPELLETTI, 1990).

Com estas influências, na década de 1870, o movimento operário francês se destaca pela audácia e inovação nas suas formas de atuar. No dia 18 de março de 
1971, o povo parisiense derruba o poder central criando a Comuna de Paris. Esta pode ser considerada a máxima expressão adquirida pela luta de classes, convertendo-se na primeira experiência de um governo proletário, com o objetivo de formar um poder democrático e popular. Lutou por benefícios tais como a abolição do trabalho noturno, a redução da jornada de trabalho, a concessão de pensão a viúvas e órfãos, a substituição dos antigos ministérios por comissões eletivas e a separação entre Igreja e Estado. Embora derrotada dois meses depois que assumiu o poder, a Comuna de Paris foi o pontapé inicial para revoluções futuras, e pelas ideias que lançou tornou-se a precursora de todas as revoluções sociais que viriam. Um exemplo é o governo proletário que se formaria em 1917, na Rússia.

Assim, fatos como a criação, em 1864, da Associação Internacional dos Trabalhadores com sede em Londres e o a própria Comuna de Paris deram origem aos primeiros partidos operários que logo de desenvolveram por toda Europa, Estados Unidos e Austrália (BRUNO, 1990) sendo a primeira vez que a classe trabalhadora propõe-se à conquista do poder político.

Com estes antecedentes, o movimento operário gesta novas formas de produção e reprodução da força de trabalho, que respondem ao contexto histórico, no qual nasce e se desenvolve.

Em 1889, cria-se a Segunda Internacional dos Trabalhadores, dissolvida em vésperas da Primeira Guerra Mundial, em 1914, porém, já havendo engendrado o Partido Social Democrata Alemão, o qual influenciou a criação dos posteriores partidos políticos de esquerda.

Entre os movimentos que a classe operária desenvolve frente à inconformidade com as irregulares formas de trabalho, destacam-se: a constituição de associações de ajuda mútua, as cooperativas e os sindicatos.

\subsection{As Associações de ajuda mútua}

Na década de 1820 foram criadas as primeiras associações de ajuda mútua tendo como base as associações integradas, fundamentalmente, por artesãos que trabalhavam sob o Domestic System, no fim do século XVIII, na Inglaterra. Na década de 1830, foi a vez de a França criar estes tipos de associações, procurando atender os casos de acidentes de trabalho, doenças e desemprego, aos quais os operários estavam expostos. Estas iniciativas influenciaram os movimentos que 
deram lugar à Revolução de 1848, a qual alcança sua máxima expressão ao reivindicar a liberdade de associação e a redução da jornada laboral para dez horas, depois de um longo período de luta que se iniciou com a primeira onda grevista, após a abolição da proibição do direito de associação em 1825 (COGGIOLA, 2010).

Foi também em 1948 que Proudhon disseminou suas ideias relativas ao que chamou de "sistema mutual", entendendo que tinha de haver um meio de permitir aos trabalhadores obter crédito monetário sem que para isso tivesse que pagar juros (LICHTHEIM, 1968). Expressava: "Lo que necesitamos, lo que reclamo en nombre de los trabajadores, es la reciprocidad, la equidad en el intercambio, la organización del crédito" (Proudhon, apud LICHTHEIM, 1968, p. 101). Dessa maneira, é possível observar a influência do anarquismo no que diz respeito à autogestão e ao associativismo mediados pelo que eles entendem por princípio de justiça. Na visão de Lichtheim, para Proudhon,

El orden social ideal es aquel en que los productores individuales intercambian libremente sus productos de acuerdo con el principio de que el trabajo crea el valor. La producción se encamina al uso y no a la ganancia, solo se intercambian excedentes y los intermediarios no cobran gravamen alguno. Esta reciprocidad es la manifestación concreta del principio cósmico de justicia. (...) El crédito gratuito e ilimitado es el fundamento del "mutualismo" pues, una vez que los productores se han liberado de la tiranía de los bancos y del pago de intereses, la única palanca de la producción es su propia capacidad para satisfacer los unos las necesidades de los otros ${ }^{7}$ (LICHTHEIM, 1968, p. 94 e 101).

Desde esta perspectiva, a função do governo devia se limitar ao seu papel político sem influir na economia, mesmo colocando em dúvida a necessidade de um governo. Em palavras de Proudhon: "La tarea del Estado es únicamente el pronunciarse sobre la justicia de las relaciones económicas, no el determinar las manifestaciones de la libertad"8 (LICHTHEIM, 1968, p. 102) e nesse sentido: "La revolución social consiste precisamente en la disolución del Estado y la inauguración de un orden social conservado a través del contrato libre"9 (ibidem, p. 102).

\footnotetext{
${ }^{7}$ Tradução livre da pesquisadora - A ordem social ideal é aquela na qual os produtores individuais trocam livremente seus produtos de acordo com o principio de que o trabalho cria o valor. A produção encaminha-se ao uso e não ao lucro, só se trocam excedentes e os intermediários não recebem. Esta reciprocidade é a manifestação concreta do princípio cósmico de justiça. (...) O crédito gratuito e ilimitado é o fundamento do "mutualismo" já que uma vez que os produtores tem se livrado da tirania dos bancos e do pagamento dos juros, o único motor da produção é sua própria capacidade para satisfazer uns as necessidades dos outros.

${ }^{8}$ Tradução livre da pesquisadora - A tarefa do Estado é unicamente se pronunciar sobre a justiça das relações econômicas, não determinar as manifestações da liberdade.

${ }^{9}$ Tradução livre da pesquisadora - A revolução social consiste na dissolução do Estado e na inauguração de uma ordem social conservada através do contrato libre.
} 
Isto vai influenciar a Comuna de Paris, a qual, segundo Meltzer e Christie, "señaló el punto más alto de la descentralización proudhonista, que en la práctica comenzó a fusionarse con el socialismo no estatal que defendía el ala bakuninista de la Internacional”10 (1970, p. 55). Assim, iniciou um processo de criação de uma sociedade organizada de baixo para cima, de acordo com os princípios que pregava o anarquismo, segundo o qual "La revolución debe ser espontánea, debe venir de abajo e debe proponerse el objetivo de prescindir del estado institución contrarrevolucionaria por su naturaleza misma"11 (LICHTHEIM, 1968, p. 102)

Mesmo que a forma de organização que adotou a Comuna de Paris não tenha prosperado, é eminente o legado que deixa em relação às possíveis formas de organização dos trabalhadores e da sociedade em geral e é nela que podem ser vistas as primeiras grandes manifestações do mutualismo, associativismo e a autogestão.

Na América Latina, as associações de ajuda mútua surgiram na década de 1850, e teriam sido influenciadas no início pelo movimento migratório proveniente da Europa, que possuía experiência associativa prévia.

A associação em grupos de ajuda mútua seria uma forma de socialização dos imigrantes, levando-os a criar vínculos de solidariedade, além de ser uma forma de garantir proteção em casos de desemprego e invalidez, assim como assistência em matéria de saúde e educação (KROPOTKIN, 1970).

Uma década depois, chegam à América Latina as ideias anarquistas, que irão contribuir com o aprofundamento das práticas associativas e de autogestão. No México, contribuíram com a formação das primeiras organizações operárias, campesinas e estudantis. Dez anos depois, na Argentina e no Uruguai, as ideias anarquistas conseguiram a adesão da maior parte da classe operária, e nos casos do Peru e Chile, influenciaram significativamente as lutas da classe operária (RAMA E CAPPELLETTI, 1990). Assim, na maioria dos países latinoamericanos, em maior ou menor medida "las primeras organizaciones obreras que trascendieron el significado de meras sociedades de socorros mutuos y encararon la lucha de clases, fueron anarquistas"12 (RAMA E CAPPELLETTI, 1990, p. 10).

\footnotetext{
${ }^{10}$ Tradução livre da pesquisadora - Assinalou o ponto mais alto da descentralização proudhonista, que na prática começou a se fusionar com o socialismo não estatal que defendia a ala bakuninista da Internacional.

${ }^{11}$ Tradução livre da pesquisadora - A revolução deve ser espontânea, deve vir de baixo e deve se propôr o objetivo de prescindir do Estado instituição contrarrevolucionária pela sua natureza mesma.

12 Tradução livre da pesquisadora - As primeiras organizações operárias que transcenderam o significado de meras sociedades de socorros mútuos e encararam a luta de classes, foram anarquistas.
} 
Desta forma, os novos tipos de conflitos sociais que emergiram contribuíram para constituir uma classe trabalhadora que começava a se mobilizar e a adotar novas formas de cooperar entre si.

\subsection{As Cooperativas}

O cooperativismo, impulsado no século XIX no continente europeu e baseado nos princípios da ajuda mútua, surge como resposta à convulsão econômica e social produzida e reforçada pelo capitalismo. Segundo Di Stefano e outros:

La actividad asociativa funcionaba como un tejido conectivo a través del cual la población podía satisfacer necesidades concretas surgidas de las nuevas relaciones económicas y sociales; construir lazos de pertenencia y solidaridad; representar y defender intereses sectoriales; desarrollar actividades recreativas, festivas, y culturales; actuar colectivamente en el espacio público ${ }^{13}$ (DI STEFANO E OUTROS, 2002, p. 106).

As origens do cooperativismo, em sua forma moderna, podem ser encontradas entre as décadas de 20 e 40 do século XIX. Em 1827, com a formação da primeira cooperativa de consumo em Grã Bretanha, com o Dr. William King, e em 1832, sob influência do Dr. Buchez, cria-se a primeira cooperativa de produção da França, porém é com os ingleses Owen e Rochdale que o movimento se torna mais conhecido (GUERRA, 1997).

O industrial Owen inova ao aplicar na suas unidades produtivas uma série de regulamentações laborais e reformas sociais. Ele desenvolve uma experiência na sua indústria de tecelagem na vila de New Lanark, que visava harmonizar as condições de trabalho, abolindo os maus tratos, educando as crianças, restringindo o trabalho infantil, incorporando subsídios médicos e promovendo a economia doméstica (PODMORE, 2004). Essas mudanças vieram acompanhadas de sistemas severos de controle, que acompanhavam o desenvolvimento de ações filantrópicas e paternalistas, e contribuíam com o bom desempenho dos trabalhadores. No fim, as experiências de Owen, que tentaram também ser replicadas nos Estados Unidos e no México, ganharam adeptos apenas da classe média, sem conquistar a simpatia

\footnotetext{
13 Tradução livre da pesquisadora - A atividade associativa funcionava como um tecido conectivo através do qual a população podia satisfazer necessidades concretas surgidas das novas relações econômicas e sociais, a construir laços de pertencimento e solidariedade, representar e defender interesses setoriais, desenvolver atividades recreativas, festivas e culturais, atuar coletivamente no espaço público.
} 
dos movimentos operários, já que as decisões continuavam vindas de cima para baixo, e não deixavam de lado os interesses capitalistas, mantendo-se as relações de propriedade privada. As cooperativas são vistas como a melhor forma de organização das unidades produtivas porque dentro delas o incentivo para 0 trabalho é maior do que apenas o salário.

Segundo Engels, este tipo de iniciativa projetava apenas um futuro harmonioso dentro do sistema capitalista, não buscando se distanciar dele, (THOMPSON, 1987; MARX E ENGELS, 1887) como ilustra a seguinte passagem:

Continúan soñando con la experimentación de sus utopías sociales; con establecer falansterios aislados, crear colonias interiores en sus países o fundar una pequeña Icaria, edición en dozavo de la nueva Jerusalén. Y para la construcción de todos estos castillos en el aire se ven forzados a apelar a la filantropía de los corazones y de los bolsillos burgueses. Poco a poco van cayendo en la categoría de los socialistas reaccionarios o conservadores descritos más arriba y sólo se distinguen de ellos por una pedantería más sistemática y una fe supersticiosa y fanática en la eficacia milagrosa de su ciencia social14 (MARX E ENGELS, 1987, p. 35).

No entanto, mesmo reconhecendo e estando de acordo com ditas críticas, as iniciativas de Owen representam uma primeira aproximação ao trabalho associativo, inaugurando o que logo foi chamado pela ala marxista, de socialismo utópico.

Outro antecedente que se reconhece no cooperativismo é o do Rochdale com o desenvolvimento da cooperativa de consumo. No ano de 1844, um grupo de tecelões ingleses fundaram a "Rochdale Society of Equitable Pioneers" com três grandes metas: a organização imediata de uma cooperativa de consumo; a organização no médio prazo de uma cooperativa de produção e moradia e a constituição de uma colônia (GUERRA, 1997). Esta experiência representa o início das cooperativas no seu estado mais puro, sentando as bases do que dois séculos depois ainda entende-se por cooperativa.

Marx defendia a "associação dos produtores livres e iguais", declarando-se favorável às cooperativas de produção, organizadas em escala nacional, e defendendo que a libertação dos trabalhadores será obra dos próprios trabalhadores

\footnotetext{
${ }^{14}$ Tradução livre da pesquisadora - Continuam sonhando com a experimentação de suas utopias sociais, com estabelecer falansterios isolados, criar colônias interiores em seus países ou fundar uma pequena lcária, edição em duodécimo da nova Jerusalém. E para a construção de todos estes castelos no ar se vêm forçados a apelar à filantropia dos corações e dos bolsos burgueses. Pouco a pouco vão caindo as categorias dos socialistas reacionários ou conservadores descritos mais acima e só se distinguem de eles por uma pedantearia mais sistemática e uma fé supersticiosa e fanática na eficácia milagrosa de sua ciência social.
} 
ou não será. No Manifesto Inaugural da Associação Internacional dos Trabalhadores, ele mesmo adverte:

A experiência do período de 1848 a 1864 provou fora de qualquer dúvida que o trabalho cooperativo - por mais excelente que em princípio [seja] e por mais útil que na prática [seja] —, se mantido no círculo estreito dos esforços casuais de operários privados, nunca será capaz de parar o crescimento em progressão geométrica do monopólio, de libertar as massas, nem sequer de aliviar perceptivelmente a carga das suas misérias. É talvez por esta precisa razão que nobres bem-falantes, filantrópicos declamadores da classe média e mesmo agudos economistas políticos, imediatamente se voltaram todos com cumprimentos nauseabundos para o preciso sistema de trabalho cooperativo que em vão tinham tentado matar a nascença, ridicularizando-o como Utopia do sonhador ou estigmatizando-o como sacrilégio do Socialista. Para salvar as massas industriosas, o trabalho cooperativo deveria ser desenvolvido a dimensões nacionais e, consequentemente, ser alimentado por meios nacionais. Contudo, os senhores da terra e os senhores do capital sempre usarão os seus privilégios políticos para defesa e perpetuação dos seus monopólios econômicos. Muito longe de promover, continuarão a colocar todo o impedimento possível no caminho da emancipação do trabalho ${ }^{15}$.

A formação destas novas estratégias de sobrevivência é entendida, antes de tudo, como novas formas de produção e reprodução da força de trabalho, que evidenciam um movimento que se impõe frente às estratégias utilizadas pelo capitalismo e que exige o envolvimento dos trabalhadores em uma luta que não é apenas econômica, é social e é também política.

\subsection{Os sindicatos}

As formas associativas que surgiram no início do século XIX também influenciaram a formação de sindicatos, uma vez derrotadas pelos operários, as leis antissindicais, promulgadas durante a Revolução Industrial, tendo seu ápice no ano de 1825 com a revogação das Combination Acts de 1799.

$\mathrm{Na}$ década de 1830, os trabalhadores ingleses formaram os sindicatos de ofício, Trade Unions; em 1830 surgiu o sindicato dos operários da construção e em 1834 criou-se a Grand National Consolidated Trade Unions, sendo a primeira central de trabalhadores.

\footnotetext{
${ }^{15}$ Texto do Manifesto Inaugural da Associação Internacional dos Trabalhadores escrito por Marx em 1864.
} 
Para Marx, os sindicatos nasceram:

dos esforços espontâneos dos operários ao lutarem contra as ordens despóticas do capital, para impedir ou ao menos atenuar os efeitos dessa concorrência, modificando os termos dos contratos, de forma a se colocarem acima da condição de simples escravos (COGGIOLA, 2010, p.13)

Nesse sentido, Marx chamava a atenção para o fato de que:

Ainda não são suficientemente conscientes de tudo o que podem fazer contra o sistema da escravidão assalariada, e mantêm-se bastante separados dos movimentos mais gerais e das lutas políticas. Ao se considerarem e atuarem como pioneiros e representantes de toda a classe operária, conseguirão reagrupar em seu seio todos aqueles que ainda não estão organizados. Ao se ocuparem das atividades mais miseravelmente remuneradas, farão nascer, nas grandes massas operárias, a convicção de que, em lugar de se circunscreverem a limites estreitos e egoístas, seu objetivo tende à emancipação de milhões de proletários subjugados" (MARX apud COGGIOLA, 2010, p. 13).

Formados primeiramente para obter melhores condições de trabalho, logo passaram a assumir caráter reivindicativo. Assim, o movimento sindical, que nasce no seio das lutas operárias inglesas, revela-se como uma das primeiras formas de organização capaz de confrontar o modo de produção capitalista. Nesse sentido, o Luddismo, iniciado no século XVIII, porém recobrando forças na primeira década do século XIX, foi um dos movimentos que demonstrou que era possível desestabilizar esta forma de produção. Com atuações também na Bélgica, Suíça e Alemanha, os "destruidores de máquinas", como ficaram conhecidos, eram um grupo de operários contrários à industrialização intensa, ao maquinismo e à inserção de novas tecnologias.

É possível identificar que, em paralelo à incipiente formação dos sindicatos que preconizavam melhorias salariais, tomava corpo um movimento que ia além dessas reivindicações, questionando as relações sociais de produção.

É o exemplo do Cartismo inglês, que liderado por um grupo de artesãos Iondrinos pediam uma reforma política ao Parlamento, reivindicando mudanças efetivas, que foram promulgadas gradualmente durante a primeira metade do século XIX, embora incluídas na legislação inglesa só em 1860. Entre elas, a Lei de Proteção ao Trabalho Infantil, limitando a jornada de trabalho a 8 horas (1833), a Lei de Imprensa (1836), a reforma do Código Penal (1837), a regulamentação do trabalho feminino e infantil, a Lei de Supressão dos Direitos sobre os Cereais, a lei 
permitindo as associações políticas e o que foi considerado como a grande conquista: a Lei da Jornada de Trabalho de 10 horas em 1847 (COGGIOLA, 2010).

Segundo Bert Andréas:

Existia na Inglaterra uma classe operária nascida da fábrica que fazia valer suas reivindicações através do poderoso movimento cartista; havia liberdade de reunião e de associação; havia, além dos numerosos operários e artesãos de todos os países europeus, exilados políticos franceses, alemães, italianos e poloneses de todas as opiniões (ANDRÉAS apud COGGIOLA, 2010, p. 9).

Na Franca, uma onda grevista mobilizou os setores operários, até os tecelões da cidade industrial de Lion promoveram a revolta de 1839-42 e a greve geral, sob o lema "viver trabalhando ou morrer combatendo" (RUDE, 1982; MOISSONNIER, 1988; DEMOUSTIER, 2006). Líderes foram mortos, operários foram detidos e o exército mobilizado para esmagar qualquer movimento revolucionário. No entanto, a organização operária continuou de forma clandestina, (já que a legislação antigreve só foi derrubada em 1864) e estimulou a mobilização em outros países, como é o caso dos tecelões alemães da Silésia, que também se levantaram, no ano de 1844.

Coggiola resume este período na seguinte passagem:

O movimento operário retomou as formas de luta características dos movimentos e classes populares que o precederam: escravos, plebeus, artesãos, camponeses. Mas não se limitou a retomá-las: também as reformulou, de acordo com as novas condições de produção (contrato "livre" de trabalho, e não mais trabalho compulsório), criando formas específicas de organização: os sindicatos. Na luta do movimento operário, porém, não houve duas fases em sequência cronológica, primeiro sindical (em defesa do valor da força de trabalho) e, só depois, política (luta pelo poder na sociedade, e pela abolição da exploração capitalista). Toda luta de classes é, ou tende a ser, uma luta política. No berço histórico do movimento operário (a Inglaterra), os sindicatos e as organizações e reivindicações politicas (sufrágio universal, Parlamento aberto aos representantes dos trabalhadores) surgiram paralelamente no tempo (COGGIOLA, 2010, p. 10).

O caráter político que foram assumindo os sindicatos deu origem às mudanças que se sucederam no decorrer da segunda parte do século XIX, principalmente a partir das revoluções europeias de 1848, cujo fracasso e as posteriores tentativas da classe proletária de se integrar ao parlamento, originando o movimento operário moderno.

Na mesma época, Marx e Engels proclamam o Manifesto Comunista convocando aos proletários do mundo a se unirem, em um momento em que "(...) 
ainda os Estados Nacionais se encontravam em formação, e o capitalismo lutava para conquistar o mundo" (COGGIOLA, 2010, p. 11). Mas foi com a Comuna de Paris que as possibilidades efetivas de luta de classe foram enxergadas pela sociedade, sendo a demonstração mais clara de que o povo é capaz de fazer uma revolução social, tomar o poder e soltar as cadeias que os aprisionam.

Assim, enquanto o socialismo se "democratizava", uma facção se agrupava no que se denominou Sindicalismo Revolucionário, como movimento que proclamava a ação direta, sem vinculação ideológico-política, oficializando-se em 1906 no Congresso de Amiens.

A Carta de Amiens, declaração realizada pela Confederação Geral do Trabalho francesa, criada em 1895, expressa em um dos trechos que se considera de máxima significância:

No trabalho reivindicativo quotidiano, o sindicato procura a coordenação dos esforços operários e a melhoria do bem-estar dos trabalhadores através da consecução de melhorias imediatas tais como diminuição das horas de trabalho, aumento dos salários, etc. Mas este labor é apenas um dos aspectos da tarefa do sindicalismo: ele prepara a emancipação integral que só pode realizar-se pela expropriação capitalista; preconiza como meio de ação a greve geral e considera que o sindicato, hoje agrupamento de resistência, será no futuro, o agrupamento de produção e de repartição, base da reorganização social. O Congresso declara que esta dupla tarefa, quotidiana e futura, decorre da situação de assalariados que pesa sobre a classe operária e que faz com que todos os trabalhadores, quaisquer que sejam as suas opiniões ou as suas tendências políticas ou filosóficas, tenham por dever pertencer ao agrupamento essencial que é o sindicato (CARTA DE AMIENS, 1906).

O sindicalismo revolucionário, que surge como uma doutrina de reação à parlamentarização dos supostos representantes da classe operária, se impulsa novamente com a Revolução Russa, após ter perdido no início do século XX, sua capacidade aglutinadora. Utilizando-se de instrumentos como a greve e a propaganda da greve geral, o operariado luta contra a burguesia, nas suas formas de Estado e Patronato, negando o poder e a lei e aniquilando qualquer possibilidade de colaboração de classes. Sendo assim, o sindicalismo revolucionário também não se aliou ao atuante partido socialista. Ao dizer de Lúcia Bruno,

É preciso que sejam os próprios trabalhadores a lutar e não que as direções (sindicais, partidárias, comissões burocratizadas) façam isso em seu nome. Quando isto acontece, as relações igualitárias 
não se constituem praticamente e são as relações capitalistas que se reforçam (1990, p. 27).

Entretanto, encontrará seu fim ao assistir à assunção dos governos autoritários, trinta anos depois, primeiro com o triunfo do Fascismo na Itália e logo com a ascensão do Nazismo na Alemanha, limitando qualquer possibilidade de luta por parte da classe trabalhadora.

O Estado cobra centralidade e toma para si as formas de produção e reprodução da força de trabalho, com mecanismos que, após a Crise de 1929, se consolidarão no que se chamou de Estado de Bem-Estar Social europeu, assunto sobre o qual se tratará no decorrer do texto.

\section{O SURGIMENTO DO MOVIMENTO OPERÁRIO NO CONTEXTO LATINO- AMERICANO E SUAS MANIFESTAÇÕES NO BRASIL E NO EQUADOR}

Quando se aborda a questão da produção e reprodução da força de trabalho, é fundamental atentar-se para as estratégias que os próprios trabalhadores adotaram, seja para melhorar suas condições de trabalho e de vida, seja para lutar contra a forma em que era concebida essa reprodução. É interessante, nesta parte do texto, analisar como os acontecimentos que primeiramente tiveram lugar na Europa se manifestaram na América Latina, especialmente no Brasil e no Equador, países estudados durante a pesquisa.

No decorrer do século XIX, os países latino-americanos assumiram um papel determinado na divisão internacional do trabalho com base na especialização, na produção de mercadorias para as quais tivessem maiores vantagens competitivas, determinadas estas, por fatores naturais, culturais, sociais e históricos. Assim, 0 Chile exportava o salitre; o Brasil produzia e exportava o café, o açúcar e os metais preciosos; o México fazia a exportação mista de minerais e produtos agrícolas; a América Central, as bananas; o Peru e a Bolívia, os metais preciosos; a Argentina e o Uruguai, os cereais e depois a carne (BETHELL, 1991).

Neste contexto, Brasil e Equador possuem, desde sua conformação, características dissimiles quanto a sua estrutura geográfica, demográfica e populacional, assim como a respeito do processo de industrialização e de sua economia. No entanto, no período pré-capitalista, nos dois prevaleciam as atividades 
primárias, as quais levaram a coincidirem nas formas que a força de trabalhado se organizou.

A exportação de produtos primários torna-se, no século XVIII e começo do século XIX, a maior fonte de renda dos países que conformaram o bloco dos primário-exportadores e, por outro lado, a maior parte dos produtos manufaturados consumidos nos países latino-americanos era adquirido via importações. Dessa forma, a atividade econômica interna encontrava-se diretamente relacionada com a demanda externa, produzindo instabilidade constante no sistema econômico, pois os preços e as condições de compra-venda dependiam fortemente dessa conjuntura.

O ambiente propício que apresentava a América Latina para a produção e a posterior exportação dos produtos para o mercado global resultou eminentemente atrativo para os países centrais. Muitos imigrantes se aventuraram a ocupar as terras dos países periféricos. Países como Argentina, Brasil e Uruguai atraiam pelas condições da terra, que permitia o cultivo de café, cereais, algodão, cana-de-açúcar, e também a criação de gado. No entanto, as terras se dividiram em grandes latifúndios e poucos donos, geralmente crioulos, tomaram conta das propriedades, resultando em uma estendida classe média e setores populares absolutamente transformados pela influência migratória. No caso das regiões andinas, o atrativo eram os minerais, entre os quais o cobre e o salitre, de precioso valor.

O desenvolvimento tecnológico do século XIX diminuiu as distâncias facilitando as comunicações entre um país e outro e entre continentes por meio de avanços na navegação. A criação e extensão das vias férreas e incremento dos trens, assim como a construção de caminhos e pontes, contribuíram com o modelo de industrialização. No entanto, a natureza de produtos homogêneos e exportação destes países e a exclusiva atenção na produção e/ou extração de matéria-prima podia predizer o iminente fracasso.

No início do século $\mathrm{XX}$, o modelo primário-exportador apresentou sinais de esgotamento, e nos anos 30, após diversas crises e guerras que atingiram especialmente os países europeus, deu-se início ao que ficou conhecido como modelo de substituição de importações.

Este modelo, na sua primeira fase, consistiu na instalação de um conjunto de indústrias de bens de consumo corrente, tais como tecidos e confecções, produtos de couro e alimentos manufaturados. O consumo destes produtos viabilizava-se por meio do crescimento das exportações que continuava a gerar renda, e a diminuição 
de importações que fazia com que boa parte dessa renda fosse investida localmente. Os materiais de construção que substituíram em grande parte os produtos artesanais também experimentaram seu auge no começo do século $X X$, devido ao processo de urbanização. Assim, sem experimentar grandes diferenças com o modelo anterior (primário-exportador) não se observaram nesta primeira fase uma mudança substantiva entre a expansão industrial e o crescimento da agricultura de exportação, de forma tal que o setor industrial se comportava apenas como um multiplicador de emprego do setor exportador (FURTADO, 1969).

Após a crise de 29, viu-se altamente afetada a capacidade de desenvolvimento dos países periféricos, dada a diminuição da disponibilidade de créditos internacionais e as flutuações nos processos de importação e exportação. De acordo com Furtado, até 1929, o desenvolvimento do setor industrial "fora um reflexo da expansão das exportações, a partir desse momento a industrialização seria principalmente induzida pelas tensões estruturais provocadas pelo declínio ou crescimento insuficiente do setor exportador" (1969, p. 131). Peru, Venezuela e os países da América Central foram exceções, pois obtiveram um importante acréscimo nas suas exportações no período subsequente.

Duas décadas se passaram após o período pós-guerra até os países da América Latina retomarem seu curso, com diferentes matizes, no processo de substituição de importações. Os casos argentino, mexicano e brasileiro foram os que melhor exemplificaram o processo. Retomando a Furtado, além da elasticidade da oferta, era essencial para que se realizasse a substituição de importações a expansão da renda monetária capaz de anular o efeito depressivo no nível de emprego da contratação das atividades de exportação (ibidem).

Nesse sentido, a superação da primeira fase da industrialização exigiu medidas econômicas que modificassem as estruturas do núcleo industrial, e os processos inflacionários apresentaram novas demandas para o Estado.

Além disto, se fazia necessária a adequação de infraestrutura que aprimorasse a que fora construída em face do modelo primário-exportador, assim como a adequação das estruturas fiscais e aumento dos encargos financeiros. De acordo com Furtado: "a elevação dos custos monetários provocada pelos processos inflacionários repercute, no setor exportador reduzindo a sua capacidade competitiva no exterior" (ibidem, p. 154). 
Desta forma, o crescimento volta-se para o mercado interno e os Estados iniciam um projeto de desenvolvimento baseado, fundamentalmente, nos princípios de autoritarismo e centralismo.

Da mesma forma que no Equador, onde a industrialização teve início no fim do século XIX apenas em duas cidades (Guayaquil e Quito), no Brasil, na mesma época, foi Rio de Janeiro e São Paulo que concentravam a maior parte das indústrias; Em ambos os países, a industrialização conviveu com a resistência dos camponeses de abandonar o campo, processo que se estendeu ao longo do século $\mathrm{XX}$.

Com o modelo de substituição de importações nasce uma nova classe: os trabalhadores industriais, operários do setor industrial que percorrerão pelo século $X X$, que pouco teve de linear e muito de lutas e transformações.

$\mathrm{Na}$ continuação, se descrevem os principais fatos que constituíram o movimento operário no Brasil e no Equador, impulsionados pelos efeitos da Revolução Industrial até a primeira metade do século XX.

\subsection{A atuação do movimento operário no Brasil}

As primeiras indústrias surgiram no Brasil somente no fim do século XIX. Tratava-se de uma região na qual havia terra para cultivo e escravos suficientes para assegurar a produção, razão pela qual a indústria não atraía e o país continuou sendo principalmente agrícola voltado para a exportação de produtos primários (GIANNOTTI, 2007).

Com esse atraso na aparição das indústrias, a classe operária foi constituída primeira e principalmente por imigrantes europeus que chegaram à região, incentivados pela possibilidade de explorar a indústria cafeteira. Eram majoritariamente portugueses, espanhóis e italianos, países nos quais a ideologia predominante dos campesinos e operários era o anarquismo, influenciando claramente, o movimento operário brasileiro até pelo menos 1920. Segundo Viñas:

Las ideas de Proudhon, Bakunin y Kropotkin lanzaron raíces en Brasil, mientras la social-democracia jamás consiguió transmitir su mensaje a las masas obreras, quedando restringida a pequeños 
grupos, en su mayoría constituidos por intelectuales y obreros de origen italiano ${ }^{16}$ (VIÑAS, 1983, p. 87).

Desta maneira, os operários que chegavam para buscar fontes de trabalho, também vinham cientes de que poderiam intervir nas formas de organização da produção à qual a América estava se adaptando. Assim, junto com o incipiente desenvolvimento da indústria, vieram também as greves. Em 1897, acontece a primeira greve que durou 15 dias e parou a cidade de Santos, o principal porto nessa época (GIANNOTTI, 2007). Mas vai ser só na primeira década do século XX que o movimento operário irá iniciar seu desenvolvimento, principalmente quando utiliza as greves (que como foi mencionado acima, já aconteciam na Europa desde o século passado) para lutar pela redução das horas de trabalho e o aumento salarial.

Frente a estas lutas, os proprietários das indústrias respondiam com repressão procurando garantir o triunfo do modelo capitalista que na América Latina estava apenas começando.

Em 1906 foi realizado o $1^{\circ}$ Congresso Operário Brasileiro (COB) influenciado fundamentalmente por ideias anarquistas. O segundo e o terceiro congresso aconteceram em 1913 e 1920, respectivamente, reunindo os operários brasileiros e organizados pela Confederação Operária Brasileira, que foi formalizada em 1908 e extinta em 1920.

Com o decorrer dos anos, a intenção de converter o movimento operário em um movimento também político foi tomando corpo, inspirados nos princípios socialistas da II Internacional, porém as ideias anarquistas continuavam sendo as mais influentes, até as primeiras décadas do século XX (GIANNOTTI, 1987).

De qualquer forma, é importante destacar que mesmo quando as ideias anarquistas perderam espaço para os princípios socialistas da Segunda Internacional, estes deixaram estabelecidos os princípios de associativismo e autogestão, que foram retomados sempre que se pensou em desenhar novas formas de criar um sistema mais igualitário e menos explorador. Foi a partir das práticas de ajuda mútua que foi possível pensar as cooperativas e que surgiram os sindicatos, é olhando para elas que se enxerga a possibilidade do movimento operário, criar formas que o emancipem e não apenas que o reproduzam.

\footnotetext{
16 Tradução livre da pesquisadora - As ideia de Proudhon, Bakunin e Kropotkin lançaram raízes no Brasil, enquanto a social democracia jamais conseguiu transmitir sua mensagem às massas operárias, ficando restringida a pequenos grupos, em sua maioria constituídos por intelectuais e operários de origem italiana.
} 
As paralizações, por exemplo, demonstram como a classe operária utiliza as armas que possui em busca de melhores condições de trabalho e de vida. Algumas de menor porte aconteceram durante os primeiros vinte anos do século $X X$, porém em 1917, ocorreu a maior greve e foi a partir dali que, influenciados agora pelo comunismo, o movimento operário se organiza por direitos mínimos, redução da jornada de trabalho e exigência do direito à livre associação. A Revolução Russa motivou os operários brasileiros e mais tarde cria-se o Partido Comunista do Brasil, em 1922, que institucionaliza os sindicatos constituídos pelos trabalhadores industriais.

No fim da década de 1920, os sindicatos iniciam um período de burocratização e foram perdendo autonomia. Segundo Giannotti, "os comitês de fábrica perderam sua autonomia e passaram a ser uma correia de transmissão dos sindicatos. O sindicato era o "motor" que decidia o movimento e os comitês seguiam automaticamente suas decisões" (GIANNOTTI, 2007, p. 90).

Os efeitos da crise de 1929 não demoraram em aparecer, a economia brasileira sustentada pela exportação de café requeria a diversificação dos produtos, iniciando pouco a pouco a era da substituição das importações, com a intervenção do Estado.

Paralelamente, surge o Movimento de Unificação dos Trabalhadores (1930), a Confederação dos Trabalhadores do Brasil (1940), o Comando Geral dos Trabalhadores (1950) e, finalmente, a Central Única dos Trabalhadores, em 1980 (BOSI DE PÁDUA, 2005). Esta, já sob certo controle do Estado, que em 1930 assume um papel regulador e interventor que irá desde o primeiro governo Vargas até a década de 1980.

Assim sendo, torna-se, segundo Giannotti, "um sindicalismo castrado, algemado, que nada tinha a ver com o antigo sindicalismo livre do começo de século. Um sindicalismo que deveria deixar de ser um touro bravo para se tornar um boi manso, pacífico" (GIANNOTTI, 2007, p.135).

É por isto que as lutas que aconteceram, mesmo sob forte repressão, foram realizadas por organizações não sindicais, tais como Comissão de Fábricas e Comitês de Greves que precisavam apenas da adesão dos operários, sem pretender ser legitimados pelo Estado (BRUNO, 1990).

Pode-se constatar na história brasileira que as características do movimento operário de início de século pareciam constituir bases fortes para o seu posterior 
desenvolvimento. No entanto, a organização em sindicatos, se bem contribuiu para iniciar processos de mudança, lutas e conquistas, também foi alvo fácil de cooptação. Assim, o processo de institucionalização pelo qual passou, limitou a sua atuação, refletindo no futuro, já que de acordo ao que Lúcia Bruno expressava em 1990, o sindicato desse momento, passou a ser nada mais do que a grande instituição de enquadramento dos trabalhadores na dinâmica do capitalismo (BRUNO, 1990), limitando toda e qualquer forma de emancipação da força de trabalho.

\subsection{As manifestações do movimento operário no Equador}

Com base em estudos de Richard Milk, de Paredes e de outros autores equatorianos mencionados no decorrer do texto, abordar-se-ão os principais fatos que envolveram a classe operária, em suas diversas fases, com mais ou menos protagonismo, de acordo com o contexto em que se deram as lutas.

O Equador é um país agrícola, que só iniciou sua industrialização no fim do século XIX, após as primeiras experiências de produção de tecidos e tapetes de forma primitiva. Esta característica influenciou fortemente no desenvolvimento de uma classe operária equatoriana, que aconteceu nas únicas três cidades industriais do país, em especial em Quito e Guayaquil que constituíram, anos mais tarde, o centro do movimento revolucionário mais intenso.

Os conflitos que caracterizavam a América espanhola no período pósindependência se agravaram pelas rivalidades regionais que havia no país. A Igreja, as elites e o governo, em estreita vinculação eram fortes controladores. Desde a década de 1880 até 1895, o "Progressismo" representou uma aliança de liberais neo-positivistas, conservadores e independentes, os quais se esforçaram para manter o controle político e introduzir os primeiros signos do modernismo, até a Revolução de 1895 (MILK, 1997). Iniciada a Revolução Liberal, houve reformas sociais, anticlericalismo, modernização, infraestruturas e, sobretudo, forte poder estatal. Os trabalhadores artesãos passaram a ser assalariados, porém essa passagem foi lenta e nunca se sucedeu completamente.

Mesmo com estes movimentos provenientes da classe operária e de alguns intelectuais, o período subsequente foi desenhado para fortalecer o controle do Estado sobre a economia e fomentar a industrialização, que incluía um projeto de 
sistema nacional de previsão social, e uma legislação que regulava as organizações laborais. O golpe de Estado de 1925 coroou este processo. Porém os anos gloriosos foram poucos, e a crise de 1929 pôs fim ao breve período de estabilidade.

As primeiras formas de associação que surgiram foram as associações de ajuda mútua, primeiramente entre grupos de artesãos possuindo uma função social adjunta à econômica. Houve um grande número de Associações que cuidavam, principalmente, dos enterros ou ofereciam apoio em casos de acidentes de trabalho. Assim, foram adquirindo diversos status, porém seu maior crescimento data de 1895, após a Revolução, com a influência de Ayala, o principal caudilho liberal. O Estado, representado agora por uma colisão de idealistas, elites agrícolas e homens de negócios que defendiam o livre comércio, apoiaram sua formação, com o fim de mobilizar a adesão ao novo regime. Segundo Milk:

Este apoyo gubernamental condujo no solamente a la formación de organizaciones asociadas con el Partido Liberal, sino que también impulsó a la Iglesia a establecer agrupaciones obreras: los Centros y Círculos Católicos de Obreros. También fue durante este período que los anarquistas establecieron sus primeros grupos ${ }^{17}$ (1997, p. 32).

Como é possível observar, as duas primeiras décadas do século XX contaram com dois movimentos de ajuda mútua que refletiam a cisão que havia no país. Por um lado, o gremialismo católico serrano com ampla ingerência da igreja católica, com escassa mobilidade social e uma marcada hierarquia no interior das oficinas artesanais de grandes proprietários de terra da região procuravam manter as crenças religiosas e conservar seus associados por meio de prestações sociais. Por outro, as sociedades gremiais liberais eram contestatórias e de resistência; estavam organizadas principalmente por sociedades comerciais, de instrução e serviços, respondendo a uma estrutura menos hierarquizada, integrada por sócios ativos e honorários (MILK, 1997).

O apoio às sociedades de ajuda mútua formou parte do programa de governo. Em 1896, influenciadas também pelo cubano Miguel Albuquerque Vives, procedente do partido Revolucionário Cubano, cria-se a Sociedad de Socorros Mutuos, Instrucción y Recreo "Hijos del Trabajo". No mesmo ano surge o Club

\footnotetext{
17 Tradução livre da pesquisadora - Este apoio governamental conduziu não somente à formação de organizações associadas com o Partido Liberal, senão que também impulsionou a lgreja a estabelecer agrupações operárias: os centros e círculos católicos de operários. Também foi durante este período que os anarquistas estabeleceram seus primeiros grupos.
} 
Guayas com um cooperativa de crédito e educação para os filhos das famílias operárias; em 1898 a Sociedad Unión de Panaderos e a Confederación Obrera del Guayas (COG), em 1905, levando as sociedades de ajuda mútua a serem a principal forma de organização laboral do país, principalmente após a Primeira Guerra Mundial, quando estas associações tinham crescido e se desenvolvido (CHAVEZ MATA, 1983).

O período compreendido entre 1909 e 1920, contando com um crescimento econômico que possibilitou o aumento do número de trabalhadores assalariados, testemunhou as mutações das associações operárias equatorianas. Surgiram os sindicatos industriais, e, em 1906 e 1907, e iniciaram-se as primeiras greves dos trabalhadores ferroviários, que lutavam por melhores salários, seguidas dez anos depois por muitas outras, quando começaram a ser sentidos os efeitos negativos da Primeira Guerra Mundial sobre a economia equatoriana. Ano a ano, em 1917, os Sartres de Quito, um ano depois, os mineiros de ouro em Portovelo, em 1919, os membros da Sociedad Tipográfica de Pichincha e em 1920 os farmacêuticos em Guayaquil, todos procuravam melhorias salariais e benefícios (VALLEJO, 1967).

Segundo Milk:

Al llegar el año 1920, acontecimientos nacionales e internacionales dieron lugar a un marco muy diferente al Segundo Congreso Obrero, del que disfrutaron los delegados a la asamblea de 1909. Los obreros habían demostrado su deseo de hacerse sentir y había terminado la Primera Guerra Mundial; además, según la forma de mucha gente de ver las cosas, la Revolución Rusa y, más cerca a casa, la Mexicana, parecían ser triunfos de los pobres sobre los ricos, engendrando un movimiento operario más militante y agresivo $^{18}$ (MILK, 1997, p.70).

Os anos que se seguiram foram marcados, por um lado, pela decadência deixada pelo pós-guerra, que incluiu queda das exportações, desemprego, subemprego e pobreza crescente; e, por outro, as associações laborais com influência cada vez maior, haviam desenvolvido uma base sólida de sociedade de ajuda mútua, formação de sociedades regionais e organização de dois congressos operários nacionais. A combinação desses elementos deu vida à greve que causou a paralização completa da cidade de Guayaquil e o posterior massacre de operários

\footnotetext{
${ }^{18}$ Tradução livre da pesquisadora - Ao chegar o ano de 1920, acontecimentos nacionais e internacionais trouxeram um contexto diferente ao Segundo Congresso Operário do que desfrutaram os delegados que participaram da assembleia de 1909. Os operários haviam demonstrado seu desejo de se fazer sentir e havia terminado a Primeira Guerra Mundial. Além disso, segundo a forma de muita gente ver as coisas, a Revolução russa é mais próxima, a mexicana pareciam ser triunfos dos pobres sobre os ricos, gerando um movimento operário mais militante e agressivo.
} 
na cidade, sob o discurso das autoridades locais e governamentais que declararam que haviam "controlado la subversión y salvado a la ciudad de un levantamiento bolchevique"19. Mesmo assim, - e talvez apenas por isso - o governo decretou o controle parcial sobre giros estrangeiros e o aumento salarial para os trabalhadores ferroviários (MILK, 1997; PAREDES, 1928).

Em 1923, foi escolhido presidente o candidato liberal Córdova, mesmo com intensas campanhas de outros candidatos com perfil de esquerda. Prevendo futuras revoltas, o Partido emitiu uma plataforma invocando reformas sociais, tais como: regulamentação laboral, principalmente para mulheres e crianças, segurança especialmente nas minas e organização laboral relativa a greves, moradia e seguro contra acidentes (MILK,1997). No entanto, os esforços dos liberais para manterem a força de trabalho aliada não foram suficientes e, três anos depois, frente ao deterioro da economia e das condições de trabalho, o proletariado organizado deu início à revolução militar e socialista de 1925. O fortalecimento dos vínculos com instituições e lideranças internacionais, a participação em eventos, a maior consciência dos acontecimentos além das fronteiras e a posse de alguns meios de comunicação contribuíram neste processo.

Conforme Milk, esta Revolução é considerada "el punto de partida de la legislación social progresista del Ecuador. Con sus logros en el campo económico y social, la revolución hizo un aporte importante al desarrollo global del sector laboral y sus instituciones"20 (1997, p. 103).

Em 1926, um novo presidente liberal, Isidro Ayora, retoma o poder, porém não desconsiderou os avanços alcançados e a Revolução de 1925 haveria influenciado a criação da Constituição de 1929 que garantia uma série de direitos, antes reclamados, inclusive garantindo uma base legal para que os operários pudessem se organizar.

O início da década de 1930 trouxe os efeitos da Crise de 1929, e além da decadência econômica, também a instabilidade política. Foi um período de diversos governos provisórios e o nascimento de uma esquerda maior e mais forte, porém foi o populismo que conquistou o governo, seguido da concessão de uma série de

\footnotetext{
19 Tradução livre da pesquisadora - Controlando a subversão e salvando a cidade de um levantamento bolchevique.

${ }^{20}$ Tradução livre da pesquisadora - O ponto de partida da legislação social progressista do Equador. Com suas conquistas nos campo econômico e social, a revolução fez um aporte importante ao desenvolvimento global do setor laboral e suas instituições.
} 
solicitações do setor operário, que depois de um amplo período de luta, já se enxergava como classe, organizando-se em assembleias.

Em 1934 e 1935, a militância continuou aumentando, dando lugar à criação dos primeiros sindicatos industriais que realizaram reivindicações permanentes em procura de melhores condições de trabalho e melhores salários. No entanto, a aparente aceitação do governo dessas novas formas de organização influenciou na forma de operar dos sindicatos, sendo mais que oponentes e aliados; ou como expressa Milk "En vez de oponerse directamente al sindicato, la gerencia intentó dividir a los trabajadores para luego aprovecharse de su debilidad"21 (1997, p.116).

Depois de 1934, os trabalhadores assalariados resolveram desenvolver seus próprios sindicatos, em vez de operar por meio das sociedades de ajuda mútua. Isto Ihes aproximou mais dos seus ideais e menos dos industriais, fazendo com que no fim da década muitos passassem por períodos de repressão e persuasão.

A luta entre o movimento operário e as diferentes facções do governo se manteve até 1944 , data em que triunfou Velasco Ibarra ${ }^{22}$, quem permitiu a criação da Confederación de Trabajadores del Ecuador (CTE). De acordo com Milk,

Con el establecimiento de la CTE, el movimiento obrero ecuatoriano logró, por fin, consolidarse a nivel nacional y prepararse para enfrentar los retos de una economía cada vez más industrializada (...) Los artesanos y sus organizaciones seguirían siendo un elemento importante en la sociedad ecuatoriana, pero los obreros asalariados Ilegarían a apoderarse del liderazgo del movimiento laboral $^{23}$ (MILK, 1997, p. 151).

Como foi observado, a maioria das associações laborais equatorianas eram de natureza artesanal, e os sindicatos industriais não tiveram grande repercussão até 1944, quando lideraram o movimento laboral. Nas décadas posteriores, houve a queda da CTE e seu posterior ressurgimento, e uma tendência da CEDOC a se tornar a Central operária mais militante do país. Porém, em 1962, surge a Confederación Ecuatoriana de Organizaciones Sindicales Libres (CEOSL) e no começo da década de 1970, o movimento operário estava constituído por três

\footnotetext{
${ }^{21}$ Tradução livre da pesquisadora - Em vez de se opor diretamente ao sindicato, a gerência tentou dividir os trabalhadores para em seguida se aproveitar de seu enfraquecimento.

${ }^{22}$ Velasco Ibarra foi presidente do Equador em cinco períodos.

23 Tradução livre da pesquisadora - Com o estabelecimento da CTE, o movimento operário equatoriano conseguiu, finalmente, se consolidar nacionalmente e se preparar para enfrentar os desafios de uma economia cada vez mais industrializada (...). Os artesãos e suas organizações seguiram sendo um elemento importante na sociedade equatoriana, mas os operários assalariados chegariam a se apoderar da liderança do movimento laboral.
} 
confederações nacionais que competiam entre si até 1976 e depois formaram o Frente Unitário de Trabalhadores (MUÑOZ E VICUÑA, 1985).

Assim, pode-se observar que primeiro as associações de ajuda mútua e depois as associações de trabalhadores se mantiveram durante pelo menos um século na luta pela melhoria das condições de vida da força de trabalho. Trata-se de movimentos que nascem no seio da classe trabalhadora, porém mediados, em diversas ocasiões pelos interesses da burguesia, seja desde as fábricas ou governo. Estes elementos influenciam diretamente as negociações entre o Estado e os trabalhadores, que acabam correndo o risco da aliança, diluindo as lutas.

Da mesma forma que no Brasil, a necessidade de sobrevivência dos operários equatorianos no sistema faz com que os sindicatos atualmente sejam atraídos a se tornarem apenas interlocutores e mediadores de conflitos, mais do que instâncias de luta e reivindicação.

\section{O PAPEL CENTRAL DO ESTADO NA PRODUÇÃO E REPRODUÇÃO DA FORÇA DE TRABALHO}

Partindo das contribuições de Marx e Engels desde uma perspectiva marxista clássica, entende-se que a natureza do Estado é ser um órgão de classe e as suas ações podem ser explicadas através da estrutura da classe capitalista, incluindo a burguesia como principal ator político que influencia na definição das ações do Estado ou beneficia-se majoritariamente delas.

Até o advento do capitalismo, os trabalhadores se dividiam em artesãos e camponeses, e as formas de atender as demandas sociais que surgiam eram de responsabilidade de grupos filantrópicos, fundamentalmente ligados à Igreja, até as primeiras associações de ajuda mútua que dependiam de agrupamentos dos próprios artesãos moradores das pequenas cidades. Até então, o Estado não tinha influência na vida social dos indivíduos.

Com a introdução do capitalismo e, principalmente, depois deste se constituir como o novo e único modo de produção, o Estado assume uma nova função: a de regular as relações de produção que se davam no interior das fábricas, principalmente em relação à legislação, após os operários se organizarem e iniciarem um longo caminho de lutas. 
Com isto, o Estado inicia um processo contínuo de "tomar para si" as estratégias criadas e desenvolvidas pelos trabalhadores industriais europeus e latino-americanos. No entanto, deu-se de forma diferente nos dois continentes. $\mathrm{Na}$ Europa, iniciou-se o Estado de Bem-Estar Social; na América Latina, que recentemente iniciava seu período de industrialização, incluía um sistema de proteção social que continha uma série de políticas desconexas e insuficientes, amplamente tutelado, que por sobre todas as coisas, buscava evitar o conflito entre capital e trabalho.

Nesse sentido, pode se observar que o Estado se serve de políticas públicas para desenvolver seu papel social. Para os efeitos deste trabalho, e sem pretender abarcar os diversos debates em torno do conceito de política social, considera-se a definição de Herrera e Boyer, segundo a qual "a política social consiste no conjunto mais ou menos coerente de princípios e ações que determinam a distribuição e o controle social do bem-estar de uma população por via política" (2003, p. 35).

Marx e Engels atentam para o fato de que as políticas públicas que expressam os interesses do capital, velando exclusivamente por eles, mesmo quando desenvolvem ações que poderão beneficiar as classes dominadas, ao dizer de Marx e Engels, "se, por vezes, os operários se unem para agir em massa compacta, isto não é ainda o resultado de sua própria união, mas da união da burguesia que, para atender seus fins políticos, é levada a pôr em movimento todo o proletariado" (1987, p.20).

Neste sentido, as políticas públicas são concebidas apenas como instrumentos funcionais para o desenvolvimento do sistema capitalista já que, como os mencionados autores expressavam no Manifesto, "para oprimir uma classe é preciso poder garantir-lhe condições tais que lhe permitam pelo menos uma existência de escravo" (MARX E ENGELS, 1987, p.26). Nesse contexto, pode se observar que as primeiras políticas elaboradas pelo Estado nasceram juntamente com o processo de industrialização e, no início, responderam apenas pela questão salarial dos operários, em um contexto de luta onde o descontentamento do proletariado ameaçava a produção e o desenvolvimento do capitalismo.

O livre mercado e a livre concorrência requerem uma organização social e política que garanta a supremacia econômica e política da classe burguesa (MARX E ENGELS, 1987). Assim, a análise marxista parte da tripla relação entre economia, classes sociais e Estado, mostrando que as relações de classe são essencialmente 
relações de poder; constituindo o instrumento analítico para a interpretação das transformações sociais e políticas que coloca a priori o Estado como um ator resultado das lutas de classes.

De acordo com Marx:

Todo interesse comum (gemeinsame) era imediatamente cortado da sociedade, contraposto a ela como um interesse superior, geral (allgemeins), retirado da atividade dos próprios membros da sociedade e transformado em objeto da atividade do governo, desde a ponte, o edifício da escola e a propriedade comunal de uma aldeia, até as estradas de ferro, a riqueza nacional e as universidades da França. [...] Os partidos que disputavam o poder encaravam a posse dessa imensa estrutura do Estado como o principal espólio do vencedor (MARX, 1982, p. 134).

Neste sentido, cabe incluir na discussão as considerações de Bernardo que, aderindo ao pensamento marxista, faz uma diferenciação entre Estado Restrito e Estado Amplo, envolvendo um novo ator: as empresas, e colocando-as em um lugar central nas estruturas de poder. Segundo ele, o Estado Restrito está constituído pelo aparelho político reconhecido juridicamente pelas Constituições dos países, envolvendo governo, parlamento e tribunais e o Estado Amplo inclui todas as formas organizadas do poder das classes dominantes. Nesse sentido, afirma que, mundialmente, o capitalismo combina o Estado Restrito com o Estado Amplo, porém chama a atenção para a predominância contemporânea deste último (BERNARDO, 1998, p.41-42).

As condições que adquiriu o capitalismo, principalmente na era neoliberal com a ampla transnacionalização e globalização em torno do comércio mundial, motivaram a predominância do Estado Amplo, reforçando a concepção marxista de que com o capitalismo, o Estado divide sua centralidade com a hegemonia das grandes corporações empresariais. Elas contam com recursos suficientes para prescindir do poder estatal, já que "elas mesmas são um poder, o mais importante na época atual" (BERNARDO, 1998, p. 47).

Em consonância com Bernardo, encontra-se o pensamento de Lúcia Bruno, que, apoiada na análise que o primeiro faz, chama a atenção para o claro boicote que o discurso neoliberal realizou ao Estado Nacional, principalmente a partir dos anos 60, enquanto buscava argumentar a eficiência do que seria um Estado Mínimo.

A autora amplia a concepção de Bernardo, considerando que há também outros atores, além das corporações empresariais, que influenciam a atual estrutura 
de poder. Ela considera uma estrutura que inclui a intervenção de agências internacionais e poderes locais, tais como organizações da sociedade civil, que conformam a estrutura, fazendo cada vez mais difuso o poder e as competências do Estado. Segundo Bruno, o Estado Nacional das ultimas décadas, "al retraerse ante este capitalismo financiero transnacional, se vuelve incapaz de definir políticas de desarrollo y de establecer líneas de acción autónomas, disimulando su impotencia bajo el mando de la neutralidad de los análisis técnicos ${ }^{24}$ ( 2006, p. 102).

A diversificação da estrutura produtiva e o crescimento econômico, a passagem de uma economia agrária para uma economia do tipo industrial, o controle dos trabalhadores com o fim de conformar uma classe empresarial nativa e a consequente acumulação de capital, assim como os efeitos da globalização que se podem observar a partir do período final do século XIX na Europa e mais tarde na América, são traços que influenciam o tipo de intervenção social adotada pelos Estados latino-americanos.

Desde a formação dos estados independentes, as políticas sociais operaram como um importante coadjuvante do desenvolvimento econômico das nações, adotando diversas formas de acordo com os diferentes períodos históricos que refletem determinada condição econômica, política e social, sendo no fim, um instrumento legitimador de ações estatais.

\subsection{Na Europa: Estado de Bem-Estar Social}

No período posterior à Segunda Guerra Mundial, o papel estatal na Europa muda significativamente, deixando de ser um agente apenas regulador, oligárquico para ser um agente interventor. Trata-se de um Estado que busca incorporar as grandes massas modificando as condições de existência da classe trabalhadora. Nesse sentido, o Estado de Bem-Estar representou um esforço de reconstrução econômica, moral e política (BARBA, 2003; ESPING-ANDERSEN, 1994).

Essa nova forma que adquire o Estado implica na sua absoluta responsabilização de assegurar condições mínimas de subsistência a todos os indivíduos da sociedade, independentemente do lugar que estes ocupem no

\footnotetext{
${ }^{24}$ Tradução livre da pesquisadora - Ao se retrair frente ao capitalismo financeiro transnacional, se torna incapaz de definir políticas de desenvolvimento e de estabelecer linhas de ação autônomas, dissimulando sua impotência sob o mando da neutralidade das análises técnicas.
} 
mercado. Neste caso, condições mínimas incluem: educação, saúde, moradia, previdência social, entre outros.

A Inglaterra foi a primeira a aprovar, no ano de 1942, uma série de providências relativas à saúde e à educação, e mais tarde outros países lhe seguiram e ampliaram a nova função, também passaram a intervir fortemente na economia, regulamentando as atividades produtivas a fim de gerar riqueza que permitiria manter o novo sistema.

Assim, pode-se observar que se tratou de um período de reforma, que buscou a construção de um consenso político entre bem-estar social, emprego e crescimento econômico. A respeito, Pereira (2000) afirma que:

La formación de una nueva clase de asalariados industriales, en el siglo XIX, en gran medida determinó el surgimiento de la legislación social y de un conjunto de medidas de protección social que pasaron a constituir, entre los años 40 y 70, los pilares del Welfare State, a saber: políticas de pleno empleo, servicios sociales universales, extensión de la ciudadanía y el establecimiento de un umbral socioeconómico, considerado merecido por la sociedad, debajo del cual nadie podría vivir' ${ }^{25}$ (PEREIRA, 2000, p.150).

Desta forma, é possível perceber uma aproximação deste novo Estado com a teoria keynesiana, a qual defende a necessidades de que o Estado participe procurando um bom nível de atividade econômica que não exclua o pleno emprego.

Este modelo de Estado não se deu da mesma forma em todos os países, nem sequer, em todas as regiões. Estudos comparativos de alguns autores, entre os quais interessa destacar Titmuss e Esping-Andersen, permitiram a classificação por tipos de Estados de Bem-Estar, segundo diferentes categorias, sempre se referindo aos países centrais.

Em 1958, Titmuss classifica os Estados de Bem-Estar em três tipos ${ }^{26}$ : residual, onde a política social intervém ex-post e possui o caráter temporalmente limitado; maritocrático-particularista, no qual a política social intervém apenas para corrigir a ação do mercado e institucional-redistributivo, voltado para a produção e distribuição de bens e serviços sociais 'extra-mercado' os quais são garantidos a todos os cidadãos universalmente cobertos e protegidos (AURELIANO E DRAIBE, 1989;

\footnotetext{
${ }^{25}$ Tradução livre da pesquisadora - A formação de uma nova classe de assalariados industriais, no século XIX, em grande parte determinou o surgimento da legislação social e de um conjunto de medidas de proteção social que passaram a constituir, entre os anos 40 e 70, os pilares do Welfare State, a saber: políticas de pleno emprego, serviços sociais universais, extensão da cidadania e o estabelecimento de um limiar socioeconómico, considerado merecido pela sociedade, abaixo do qual ninguém poderia viver.

${ }^{26} \mathrm{Na}$ versão original, os nomes são: Residual Welfare Model of Society, Industrial Achievement Performance Model of Social Policy e Redistributive Model of Social Policy.
} 
FIORI, 1995).

Mais tarde, Esping-Andersen, sem desconhecer a categorização feita por Titmuss, cria outra classificação, relacionando-a à matriz de poder que torna esses modelos viáveis, chamados de Liberal, Corporativo e Socialdemocrata, sendo que, segundo o autor, são as determinações de sua trajetória política que os diferenciam. "Cada uno de ellos está organizado con su propia y diferente lógica de organización, estratificación e integración social. Los orígenes de cada uno se deben a distintas fuerzas históricas y siguen unas trayectorias de desarrollo cualitativamente diferentes $^{27 ”}$ (ESPING- ANDERSEN, 1993, p.19).

O tipo de Estado Liberal representa o caso dos Estados Unidos, Canadá e Austrália. Existe um mínimo universal sob o qual não é permitido à população viver, independentemente do mundo do trabalho. Os subsídios que existem são apenas para a população de baixa renda, dualizando a população entre pobres e não pobres. Por outra parte, o Estado intervém minimamente no mercado, deixando que este seja o máximo regulador.

O Estado de Bem-Estar Corporativo é fortemente conservador. Áustria, França, Alemanha e Itália podem ser colocadas nesta classificação. É importante para este Estado que se mantenham as desigualdades entre o status dos indivíduos, sendo que as políticas sociais estão diretamente relacionadas com as classes sociais. Neste caso, os subsídios dependem quase totalmente dos aportes que os indivíduos façam, e por tanto, do nível de inserção no mercado do trabalho.

O tipo Socialdemocrata, como os países escandinavos, baseia-se no principio de assegurar um mínimo universal elevado, que garanta os mesmos direitos para todas as classes sociais. Procura a promoção da igualdade e a elevação das classes mais baixas, e coloca o pleno emprego como estratégia para elevar a qualidade de vida.

Ambas as classificações feitas pelos autores mencionados chamam a atenção para as diferenças que os modelos de Estado de Bem-Estar Social adotaram nas diferentes regiões. Mas, principalmente, advertem para a questão da incorporação na cena social e econômica do ator chamado Estado, em um papel protagonista, diferente do como vinha se apresentando no decorrer da história.

\footnotetext{
${ }^{27}$ Tradução livre da pesquisadora - Cada um deles está organizado com sua lógica própria e diferente de organização, estratificação e integração social. As origens de cada um se devem a distintas forças históricas e seguem trajetórias de desenvolvimento qualitativamente diferentes.
} 
Por outro lado, não se pode deixar de observar que as raízes originárias deste processo encontram-se, basicamente, na conjunção de diversos elementos, com destaque para as lutas efetuadas pela própria força de trabalho, que enquanto buscava sua sobrevivência, encontrava sua reprodução.

Dessa forma, o Estado de bem-estar é o resultado da combinação do reformismo socialdemocrata, o socialismo cristão, as elites políticas e econômicas conservadores e os grandes sindicatos industriais. Estes atores outorgaram esquemas amplos de seguro obrigatório, leis sobre proteção do trabalho, salário mínimo, expansão dos serviços sanitários, educativos e moradia subvencionada, assim como o reconhecimento dos sindicatos como representantes econômicos e políticos legítimos do trabalho (OFFE, 1990).

Este modelo desenvolveu-se até a década de 1970, onde inicia sua decadência, em um momento em que aparecem uma série de problemas econômicos ou como expressou Hobshawn: "La historia de los veinte años que siguieron a 1973 es la historia de un mundo que perdió su rumbo y se deslizó hacia la inestabilidad y la crisis"28 (HOBSBAWN, 1995, p. 404).

O capitalismo pedia agora uma reestruturação. O Estado ofereceu um novo modelo: o neoliberalismo, sobre o qual se explanará no próximo capítulo.

\subsection{Na América Latina: Sistema de proteção social baseado no trabalho}

As transformações operadas em matéria social, econômica e ideológica nos países mais desenvolvidos repercutiram na América Latina. Embora não se possa dizer que houve nesta região um Estado de Bem-Estar Social, os diferentes países desenvolveram políticas de proteção social que, em todos os casos, colocaram o Estado em cena. Segundo Filgueira, as políticas adotadas na América Latina "apresentaram um desenvolvimento limitado, fortemente orientado para os setores urbanos e com cobertura preferencial, senão única, para os setores integrados ao mercado de trabalho formal, excluindo os trabalhadores rurais e/ou informais (FILGUEIRA, 1998, p. 79).

Durante o modelo primário exportador, o papel político e o poder econômico não se diferenciavam. Os donos do capital eram os mesmos que tomavam as

${ }^{28}$ Tradução livre da pesquisadora - A história dos vinte anos que seguiram a 1973 é a de um mundo que perdeu seu rumo e se inclinou para a instabilidade e a crise. 
decisões políticas em função dos seus interesses, herdando da colônia, figuras como os caudilhos que se tornariam potenciais lideranças. Estes são elementos provenientes das oligarquias regionais que se consolidam como novos líderes, em substituição ao poder da metrópole, oferecendo proteção para aqueles que se colocam sob a sua tutela. Esses oligarcas são a pedra fundamental dos nascentes Estados latino-americanos que, como primeira função, recebem a tarefa de garantir a independência política e as fronteiras delimitadoras dos territórios recém-libertados contra as oligarquias vizinhas (ROUQUIÉ, 1994).

Neste cenário, o papel do Estado limitava-se a oferecer garantias das condições de trabalho tanto aos imigrantes como ao restante da população, os quais eram atores indispensáveis para mobilizar e colocar em funcionamento o incipiente sistema econômico. Além disto, a grande heterogeneidade populacional, que combinava imigrantes com população rural e urbana, fez necessária a homogeneização de valores e comportamentos que propiciaram sentimentos de pertencimento com a região e entre seus habitantes, tornando-se mais uma função que o Estado adotaria.

Em toda a América Latina no século XIX, o Estado, preocupado com o grande fluxo migratório internacional e com as tênues fronteiras deixadas pelo processo de independência, orientava suas ações com base na homogeneização de símbolos. Por meio de políticas de educação básica, patrocinava o idioma comum e a formação de valores nacionais (PINHEIRO, 1995, p. 69).

O papel das políticas sociais durante a vigência do modelo primárioexportador foi assegurar condições básicas de subsistência, assim como de empregabilidade tanto para os habitantes locais quanto para os imigrantes, que garantiram o funcionamento adequado dos sistemas produtivos regionais (PINHEIRO, 1995).

Ao se iniciar o modelo de substituição de importações, o Estado se direciona no sentido de proteger a atividade econômica nacional, promover a acumulação inicial de capital, fornecer melhor infraestrutura e planejando o novo modelo. Do mesmo modo, os governos populistas que apareciam na cena política, criam novas formas de se relacionar com as classes trabalhadoras, no intuito de assegurar o bom andamento do sistema de produção, novo e auspicioso.

São exemplos muito ilustrativos os governos populistas de Getúlio Vargas no Brasil, no período de 1930 a 1945, e o governo de Juan Domingo Perón, na 
Argentina, durante os anos 1946 a 1955, e um segundo e curto período que foi desde o ano 1973 até sua morte, em 1974. Outro exemplo ilustrativo deste processo foi o governo de Lázaro Cárdenas del Rio, no México, que ocupou a presidência nos anos 1930-1940 e se destacou pela incorporação das grandes centrais operárias, consolidando as bases do Partido Nacional Revolucionário e a instauração do governo populista, encabeçado por José María Velazco Ibarra, no Equador.

Nesse sentido, Pinheiro traz para a reflexão a concepção de que as políticas sociais são a expressão instrumental do populismo, tendo dois objetivos: "proteger o trabalhador assalariado, cooptando-o para conferir sustentação ao regime autoritário, e apoiar a consolidação de grupos sociais com capacidade de demandar os novos bens manufaturados nacionais" (PINHEIRO, 1995, p. 73).

\section{De acordo com Bruno,}

As politicas públicas que emanam do Estado, desde que surgiram de forma mais estruturada no conjunto de ações-fins, no início do século $\mathrm{XX}$, nunca implicaram gestão democrática das mesmas. Ao contrário, sua gestão sempre foi um atributo dos gestores desse aparelho de poder e sempre serviram aos interesses do Estado e da classe que o controla, ainda que em determinados momentos esse aparelho de poder tenha sido obrigado a incorporar exigências da classe trabalhadora, para evitar rupturas revolucionárias. Mas, no âmbito das políticas e dos serviços destinado à classe trabalhadora, esta jamais foi sequer consultada acerca da pertinência das mesmas (2002, p. 30).

Com o desenvolvimento do novo modelo econômico, as políticas de normatização salarial ficaram insuficientes, sendo sucedidas por uma série de medidas que fazendo parte das agendas públicas, influíram no desenvolvimento da força de trabalho.

Neste cenário, surge uma nova classe política, constituída principalmente pela classe média, a qual legitimaria as decisões por vezes autoritárias e sempre centralistas dos governos em pauta. A Seguridade Social veio para favorecer a consolidação do mercado interno, por meio de políticas sociais diretamente ligadas à condição laboral. Os trabalhadores industriais ganharam legislações trabalhistas mais avançadas que no período anterior, entre as quais se destacam o seguro desemprego, salário mínimo, jornada de trabalho de oito horas, o direito à negociação coletiva e à associação em sindicatos, entre outras, dependendo de cada país analisado. Desta forma, o Estado, através de incentivos dirigidos à classe 
urbana, garantia a participação ativa da força de trabalho nas atividades industriais, pactuando com ambas as esferas.

No final dos anos 60 e na década de 70, novos atores fizeram parte da cena governamental e econômica. Grupos empresariais corporativos e grupos de trabalhadores provenientes do setor industrial se incorporaram ao aparelho estatal, com voz e voto, no qual por meio de pressão política, influenciaram no desenho de políticas públicas e econômicas de acordo com os seus interesses. Da mesma forma, os grupos mais envolvidos na luta política, acessaram com maior facilidade aos benefícios públicos.

Diferente da Europa, onde as políticas públicas tiveram um papel central, a América Latina experimenta diferentes modelos e resultados, passando da estatização à privatização dos serviços públicos e da tentativa de universalização à efetivação da focalização dos programas e benefícios sociais, assuntos ampliados no próximo capítulo. Assim, segundo Barba,

En términos generales no se puede hablar de la existencia y continuidad de estados del bienestar en América Latina, donde con muy escasas excepciones no ha prevalecido de manera duradera la democracia, ni se han garantizado todos los derechos civiles o políticos 0 se han desarrollado significativamente los derechos sociales para toda la población, ni la clase obrera ha sido un factor crucial en la evolución de la política social, por lo contrario, estas ausencias han sido bastante comunes en la región ${ }^{29}$ (BARBA, 2004, p. 13).

Nesse sentido, é importante destacar que no interior da América Latina também se observam importantes diferenças. Algumas delas serão colocadas a seguir para os casos do Brasil e do Equador.

\subsubsection{O caso do Brasil}

É importante destacar que no Brasil não se configurou um Estado de BemEstar semelhante ao dos países centrais. Não obstante, a partir dos anos 30, ampliou-se o grau de intervenção estatal na economia nacional, tendo seu maior auge durante o período da ditadura militar (1964-1985). No entanto, quem se

\footnotetext{
${ }^{29}$ Tradução livre da pesquisadora - Em termos gerais não se pode falar da existência e da continuidade de Estados de Bem-Estar na América Latina, onde com poucas exceções não prevaleceu de maneira duradoura a democracia, nem foram garantidos todos os direitos sociais ou políticos para toda a população, nem a classe operária foi um fator crucial na evolução da política social, pelo contrário, estas ausências foram bastante comuns na região.
} 
beneficiou com o investimento do gasto público e com as transformações que vieram no decorrer desses anos, em infraestrutura e construção de grandes empresas públicas, foram os empresários brasileiros e estrangeiros e não os operários.

De acordo com Filgueira ${ }^{30}$, o Brasil faz parte do que ele chama de Modelo de Estado Social Dual que se caracteriza por desenvolver um modelo de substituição de importações apoiado nas rendas que se derivam das economias primárias, com alta intensidade de mão de obra e com uma grande heterogeneidade regional nos níveis de desenvolvimento econômico e social, reproduzindo uma estrutura altamente federalista, incluindo o mecanismo de clientelismo e paternalismo no acesso aos benefícios por parte da população de baixa renda (FILGUEIRA, 1998).

No mesmo sentido, George Kornis, em sua tese de doutoramento, sintetiza as principais características do sistema de proteção social brasileiro, ressaltando que se trata de "um financiamento regressivo do gasto social e uma hipertrofia burocrática que eleva em muito o custo operacional e favorece a manipulação clientelística". E continua expondo que se trata de um Welfare State particularista "fundado na capacidade contributiva do trabalhador e num gasto público residual financiado por um sistema tributário regressivo. Um sistema não-redistributivo e montado sobre um quadro de grandes desigualdades e de misérias absolutas" (KORNIS, 1994, p.58-59).

Nesse sentido, em seus primeiros discursos, Vargas, quem assumia a presidência do país em 1930, expressava:

\begin{abstract}
Não se pode negar a existência da questão social no Brasil, como um dos problemas que terão de ser encarados com seriedade pelos poderes públicos. Se o nosso protecionismo favorece os industriais, em proveito da fortuna privada, corre-nos, também, o dever de acudir ao proletário com medidas que Ihe assegurem relativo conforto e estabilidade e o amparem nas doenças como na velhice. A atividade das mulheres e dos menores, nas fábricas e em estabelecimentos comerciais, está em todos as nações cultas subordinada a condições especiais que, entre nós, até agora, infelizmente se desconhecem.
\end{abstract}

Tanto o proletário urbano como o rural necessitam de dispositivos tutelares, aplicáveis a ambos, ressalvadas as respectivas peculiaridades.

Tais medidas devem compreender a instrução, educação, higiene, alimentação, habitação, a proteção às mulheres, às crianças, à invalidez e à velhice; o crédito, o salário, e, até, o recreio, como os desportos e a cultura artística. É tempo de se cogitar da criação de escolas agrárias e técnico-

\footnotetext{
${ }^{30}$ Para saber mais sobre a classificação dos Estados de Bem-estar na América Latina ver FILGUEIRA, Fernando (1998): "El nuevo modelo de prestaciones sociales en América Latina. Eficiencia, residualismo y ciudadanía estratificada". Em: "Ciudadanía y Política Social". Robert, B. (editor). Editorial FLACSO. San José, Uruguay.
} 
industriais, da higienização das fábricas e usinas, saneamento dos campos, construção de vilas operárias, aplicação da lei de férias, lei do salário mínimo, cooperativa de consumo, etc (VARGAS, 1930, apud OLIVEIRA, 1985, p. 137).

Desta forma, novas medidas surgiram com a assunção de Vargas na presidência que buscaram regular a relação entre o capital e a força de trabalho, de forma em que a industrialização finalmente acontecesse.

Nesse sentido, podem ser identificados dois momentos: um período de conquistas de leis trabalhistas, mesmo com perdas em relação às lutas dos movimentos operários, pois estes foram "captados" e institucionalizados pelo populismo de Vargas, que ofereceu melhores condições em troca de maior produção; e um segundo momento caraterizado, principalmente, pelo caráter regressivo dos mecanismos de financiamento do gasto social.

Durante o primeiro período, conhecido como "Era Vargas", uma das primeiras medidas tomadas foi a criação do Ministério dos Negócios do Trabalho, Indústria e Comércio, e a Lei $n^{\circ} 19.770$ de Sindicalização, buscando colocar os sindicatos e a classe operária sob o controle da burguesia nacionalista. Seguiram-Ihe um conjunto de novas leis trabalhistas e sociais, entre as que se encontram a jornada de trabalho de 8 horas e o descanso semanal remunerado (1932), lei de férias (1933), lei sobre acidentes de trabalho e assistência e previdência social (1934), salário mínimo (1940), entre outras.

Com essas reformas em pauta, a partir de 1945, incorpora-se o padrão produtivo e tecnológico dominante nos países mais industrializados, facilitando a acumulação capitalista no país pelo controle e a integração limitada da classe operária, onde os sindicatos passam a ser moderados e restritos na sua ação. Foi uma época em que o número de assalariados aumentou significativamente, principalmente no fim da década de 1950, por causa do desenvolvimento da indústria de base, de bens de consumo duráveis e de bens de capital, com forte presença da atividade produtiva estatal e do capital multinacional (COSTA, 2005).

É importante destacar que durante os primeiros anos da década de 1930, a relação entre governo e sindicatos se deu principalmente por meio de negociações e concessões. Porém, desde o golpe de 1937, a ação dos sindicatos foi claramente delimitada e definida no decreto-lei de 1939 onde se "estabelece que os sindicatos só teriam poder de representação se fossem reconhecidos pelo Estado, cabendo a este o completo controle administrativo e político de suas atividades" (COSTA, 2005, 
p.113). Desta forma, amplia-se a intervenção do Estado no mercado de trabalho, ao mesmo tempo em que o sistema de proteção social se ocupa unicamente dos trabalhadores formais, deixando por fora o resto da população. Ou seja, as políticas sociais se destinavam unicamente para o setor de trabalhadores assalariados, aqueles que se submetiam à gestão totalitária da empresa, enquanto se formava um amplo grupo paralelo de trabalhadores informais e autônomos em condições absolutamente precárias à margem de todos e qualquer direito trabalhista.

Nesse sentido, a organização sindical foi uma concessão do governo varguista em conformidade com seu projeto populista, que incluía cooptar e disciplinar as mobilizações operárias daquele momento (MORAES FILHO, 1978).

Em um segundo momento, encontram-se as ditaduras militares que duraram mais de vinte anos, aprofundando um modelo no qual as melhorias das condições de vida da população se encontravam em absoluta e estreita relação com o desenvolvimento econômico, e mais, aquelas se tornaram funcionais a este. A Reforma do Sistema Financeiro Nacional e a Reforma Tributária, adotadas pelo regime militar entre 1964 e 1967, são alguns dos exemplos que se encontram na história brasileira.

Os movimentos operários que tinham reiniciado suas atuações foram, desta vez cruelmente contidos nas suas ações em nome da segurança nacional. Sem greves nem manifestações políticas, os trabalhadores tiveram de se submeter ao regime imposto pelo Estado interventor, que incluía novas medidas na legislação trabalhista, limitando cada vez mais o direito do trabalhador. Assim, os sindicatos passam ao controle do Estado, quem exige por meio de decretos, a obrigatoriedade "dos serviços assistenciais, como cooperativas de consumo e de crédito, assistência jurídica, hospitalar, escolas profissionais, etc.” (GIANNOTTI, 2007, p. 120).

Diferente ao período liderado por Vargas, em que havia uma intenção clara de cooptação dos trabalhadores, no período da ditadura militar, essa preocupação era inexistente, valendo-se do poder repressivo para ampliar o grau de exploração da força de trabalho. A disciplina e o controle sobre os trabalhadores eram suficientes para conter qualquer manifestação (NORONHA, 1998; HUMPHREY, 1982).

No entanto, no fim da década de 1970, "a gestão despótica sobre a força de trabalho no interior das empresas e o controle oficial rígido sobre os salários fomentavam terreno fértil para a manifestação das insatisfações operárias 
reprimidas pelo regime militar" (COSTA, 2005, p.117). Iniciou-se uma onda de greves e um movimento que promovia a desvinculação dos sindicatos da tutela estatal e exigia a volta de um sistema democrático, que retomara os direitos anulados pelo regime militar.

Com a redemocratização, os sindicatos são permitidos a atuar novamente, ocupando-se principalmente da defesa dos salários, criando duas centrais de trabalhadores, a CUT e a CGT e com elas a retomada das negociações entre os trabalhadores e o patronato, que trouxe novas conquistas, incluídas na Constituição de 1988, que representou um avanço importante na legislação, ampliando os direitos sociais e trabalhistas. No entanto, nos anos 90 , inicia-se um período de "política de negociação e cooperação entre capital e trabalho em torno de projetos mútuos e específicos de autopreservação" (COSTA, 2005, p. 120), de acordo com a nova conjuntura econômica, assunto abordado no capítulo seguinte.

Foi por esses trilhos que andou o trem do sistema de proteção social que como foi colocado, não alcançou o caráter de Estado de Bem-Estar, pelo menos não como ele é entendido nos países centrais. Tratou-se apenas de um leque de políticas que inteiramente relacionadas com a condição laboral da população, contribuíram para atenuar as tensões sociais e ao mesmo tempo, garantir o controle das condições de vida da força de trabalho, necessária para dar andamento ao tardio processo de industrialização.

\subsubsection{O caso do Equador}

Igual ao caso brasileiro, não se pode falar de um Estado de Bem-Estar Social no Equador, mesmo identificando algumas reformas sociais, a partir da década de 1950. Ambos os países coincidem em que o que houve foi um modelo de proteções estatais baseadas no trabalho.

Este modelo de proteção pode-se observar no período que vai dos anos 50 até o início da década de 80 , e se caracteriza pelo paradigma da industrialização substitutiva de importação, reformas agrárias, e pela presença de um Estado articulador da política e da economia e impulsor de processos organizativos e corporativos a nível social (VÁSCONEZ, CÓRDOBA E MUÑOZ, 2005). 
Segundo Filgueira, o Equador corresponde dentro de sua classificação ao regime excludente, pois os sistemas de proteção e seguridade social consistem:

En su mayor parte de políticas elitistas que agregan a población en situaciones privilegiadas, privilegios adicionales. Profesionales, un muy reducido número de trabajadores formales y los funcionarios públicos son quienes típicamente se ven favorecidos en estos modelos. La mayor parte de la población representada en el sector informal, la agricultura y la mano de obra secundaria se encuentran excluidos $^{31}$ (FILGUEIRA, 1998, p. 91-93).

Segundo Barba, tanto no regime dual, onde se localiza o Brasil, e no regime excludente, onde se inclui o Equador (segundo a classificação de Filgueira), se encontram países que possuem alta heterogeneidade étnica e informalização dos mercados laborais (BARBA, 2003). Neste tipo de regime, a população se integra de forma lenta nos serviços educativos e de saúde, havendo nula distribuição de renda, o que aprofunda a desigualdade entre as diferentes classes sociais.

Nas páginas anteriores foi relatado como as associações de ajuda mútua foram fundamentais para atender a questão social equatoriana no meio de lutas operárias pela defesa dos direitos sociais e trabalhistas, no início do século XX. No entanto, essas organizações beneficentes foram cedendo passo para organizações assistenciais que vieram de mãos dadas com a intervenção do Estado. O Estado utiliza o modelo de Junta de Beneficência de Guayaquil, que foi desenvolvido por um grupo de filantropos, e durante o governo de Eloy Alfaro se criam instituições individuais e desarticuladas chamadas Juntas de Beneficência (DE LA TORRE, 2001). Foi uma primeira tentativa de reproduzir um modelo iniciado pela sociedade civil, em um instrumento de Estado.

Após a Revolução Juliana, em 1925, cria-se o Ministerio de Previsión Social y Trabajo e a Asistencia Pública, visualizando à elaboração de políticas sociais como um dever do Estado moderno. Essa passagem da beneficência para a assistência pública provoca a descentralização administrativa e coloca o Estado como instância de controle que vai se estender desde a década de 1930 até o fim dos anos 1970. Neste período, desenvolveram-se políticas sociais homogêneas com tendência à universalização, porém, não conseguiram ultrapassar o status de

\footnotetext{
${ }^{31}$ Tradução livre da pesquisadora - Em sua maior parte de políticas elitistas que agregam à população em situações privilegiadas, privilégios adicionais. Profissionais, um reduzido número de trabalhadores formais e os funcionários públicos são quem tipicamente se veem favorecidos nestes modelos. A maior parte da população representada no setor informal, a agricultura e a mão de obra secundária se encontram excluídos.
} 
ações desconexas que se reproduzem em cada administração e também dentro da gestão de um mesmo governo (MARCHÁN, 1992).

No período de 1948 a 1960, são focalizados os problemas do país em termos de produção, e as questões sociais passam a ser atendidas por programas financiados e assistidos com ajuda externa, gerando grandes dívidas que aumentaram a condicionalidade sobre as linhas de crédito internacional e diminuíram a margem de manobra dos governos (VÁSCONEZ, CÓRDOBA E MUÑOZ, 2005).

$\mathrm{Na}$ década de 60, começa uma onda de "Planos de desenvolvimento" que, baseados na reforma agrária, tributária e administrativa, buscavam acelerar o crescimento econômico e melhorar as condições de vida da população por meio da implementação de reformas no investimento e na poupança, com financiamento externo, atendendo o setor dos recursos humanos, a saúde e a educação. Estas propostas foram facilitadas com a incorporação do petróleo que ampliou o capital disponível e aumentou a facilidade dos créditos externos. A época de bonança permitiu a formulação de diversos programas sociais, além de subsídios e estímulos ao setor privado, aumentando em extremo o gasto público, de forma a provocar o grande endividamento externo do qual nenhum dos países latinoamericanos escapou (SIERRA, 1994; VÁSCONEZ, CÓRDOBA E MUÑOZ, 2005).

Neste cenário, segundo Vásconez, Córdoba e Muñoz (2005), desde os anos 70 e 80 , as políticas públicas tentam responder basicamente a quatro objetivos: (1) coesão social que busca atenuar os conflitos e pressões sociais, (2) cumprimento das condições, requerimentos e receitas impostas pelos organismos internacionais, (3) manutenção de condições mínimas de bem-estar, e (4) manter e gerar lealdades político-eleitorais com lideranças políticas.

Foi só em 1979, ano em que se restaura a democracia no país, que se criou - Ministerio de Bienestar Social, o qual pretende unificar e articular as ações estatais da área social, buscando "establecer un eje articulador y ordenador de una serie de acciones disgregadas"32 (MARCHÁN 1992, p. 41).

Desta forma, a passagem para a democracia trouxe também o incremento da cobertura e o acesso a serviços sociais básicos, focando-se principalmente para o setor da saúde e da educação. No entanto, a partir de 1983, iniciaram-se

32 Tradução livre da pesquisadora - Estabelecer um eixo articulador e ordenador de uma série de ações desconexas. 
os recortes orçamentários e a redução dos gastos sociais, os quais se agravaram no fim da década, quando começa o período de abertura econômica, e com isto, a eliminação do controle dos preços, a flexibilização dos impostos para as elites, a liberalização do controle das importações e exportações entre outras medidas tomadas.

Durante esse período, o movimento operário se desenvolvia a passos lentos, primeiro vinculado ao clero e depois de forma independente. Com o decorrer do tempo, foi aumentando a adesão de organizações industriais e rurais e criando novas centrais sindicais que no começo se opunham e competiam entre si, até 1975 onde iniciaram um processo de ação conjunta (MILK, 1997).

Uma dessas ações, foi a greve nacional de 1982, organizada pelo Frente Unitario de Trabajadores (FUT), que reunia as principais centrais de trabalhadores do momento. Este surgiu em resposta às medidas impostas pelo governo, relacionadas às primeiras imposições de ajuste do FMI, ao fim dos subsídios, aumento do preço da gasolina, entre outras que afetavam a população. A negociação entre o governo e o sindicato, e as concessões de ambos, resultante deste processo de paralização trouxe novas alianças entre os setores, minimizando o processo de luta e o que era previsto como uma greve sem data para acabar, chegou prontamente ao seu fim.

Outras paralizações aconteceram, mas sem grandes impactos, até a posse do Presidente León Febres Cordero, em 1984, o qual suprimiu a ação de operários e dirigentes sindicais. No fim da década, com a presidência de Borja, abriram-se novas possibilidades de diálogo com os sindicatos, porém estes não chegaram a adquirir a força necessária para influir no desenrolar dos acontecimentos. Assim, com as transformações advindas a partir da década de 1980, os movimentos organizados em sindicatos têm recortados os recursos e veem limitadas suas capacidades de mobilização. Durante os últimos governos, tanto os sindicatos quanto os grêmios têm se limitado a fazer reclamações salariais e de cumprimento de gasto público, e não se ocupam da luta pela melhoria das condições de vida dos operários, sem significar grandes pressões para os Estados. As centrais sindicais, por sua vez, passam por um processo de burocratização, deixando de representar os interesses da classe que lhes dera origem.

Neste cenário, o Estado equatoriano, que teve diversas interrupções no processo democrático, desenvolveu um modelo de proteção social que baseado 
em uma economia orientada para o exterior, executou políticas sociais desconexas, estandardizadas e com mínimas cargas de proteção social (VÁSCONEZ, 2003), que permitiram o desenvolvimento e a continuidade dos processos de flexibilização laboral.

A partir do exposto, pode-se observar que tanto a Europa como a América Latina tiveram, historicamente, de criar e recriar formas e estratégias para desenvolver e manter a força de trabalho, já que desde a Revolução Industrial esta se tornou o eixo que possibilita ou não, o funcionamento do sistema capitalista. Diversos atores interviram em momentos específicos, com maior ou menor influência, às vezes na forma de resistência, às vezes cedendo às investidas do capital.

De qualquer forma, trata-se de um período de fundamental importância para compreender as manifestações que deles decorrem, no século XXI, quando há novos contextos, novos interesses, novos donos do capital e novos trabalhadores, que em conjunto, consolidam novas formas de garantir a produção e reprodução da força de trabalho.

Assim, este percurso histórico, mesmo que resumido, buscou caracterizar as bases históricas, institucionais e políticas do sistema de relações de trabalho no Brasil e no Equador, retomando antecedentes da Europa e da América Latina, procurando oferecer insumos para a análise posterior.

Com base no exposto, no próximo capítulo serão abordadas as transformações no mundo do trabalho no novo contexto: o neoliberalismo de mercado e de Estado. 


\section{CAPITULO II}

\section{PRODUÇÃO E REPRODUÇÃO DA FORÇA DE TRABALHO NA ERA NEOLIBERAL: O QUE PERMANECE E O QUE MUDA}

No capitulo anterior, foi possível observar as principais mudanças ocorridas a partir do século XIX em relação à produção e reprodução da força de trabalho, focalizando, principalmente, a função do movimento operário após a Revolução Industrial e , já no século XX, o protagonismo que adquire o Estado, conduzindo e garantindo o seu desenvolvimento. Os anos 90 do século passado apresentaram uma nova conjuntura, na qual ambos os papéis, assim como as estratégias utilizadas por eles, deveriam mudar.

O fim do Estado de Bem-Estar na Europa e as crises econômicas que afetam os países latino-americanos adubam o terreno para a total entrada e domínio das políticas neoliberais. Nesse sentido, primeiro Argentina e Chile (na década de 70), logo México, Equador e Bolívia nos anos 80, e posteriormente Brasil, Peru, Colômbia e Uruguai, começaram um significativo período de mudança, baseados em dois pilares principais: a liberalização da economia e a reforma do Estado. Trata-se de um processo que encontra sua gênese na Europa dos anos 50 - 60, e que irá influenciar diretamente o comportamento político, econômico e social dos países da América Latina.

O neoliberalismo rejeitará a noção de economia dirigida, planejamento e Estado intervencionista, para mitigar os efeitos adversos dos ciclos econômicos, apostando no livre arbítrio do mercado, formando o que Foucault analisou olhando para o neoliberalismo alemão e norte-americano, uma nova soberania política (FOUCAULT, 2008). Segundo ele:

Tratava-se de achar um paliativo jurídico para pedir a um regime econômico o que não se podia pedir diretamente nem ao direito constitucional, nem ao direito internacional, nem [...] aos parceiros políticos [...] Ela (a liberdade econômica) produz um consenso permanente de todos os que podem aparecer como agentes no interior, dentro desses processos econômicos. Agentes como investidores, agentes como operários, agentes como empresários, agentes como sindicato. Todos esses parceiros da economia, na medida mesma em que aceita esse jogo econômico da liberdade, produzem um consenso que é um consenso político. [...] Ou seja, a adesão a este sistema liberal produz como subproduto, além da legitimação jurídica, o consenso permanente e é o crescimento 
econômico, é a produção de bem-estar por esse crescimento que vai, simetricamente à genealogia "instituição econômica-Estado" produzir um circuito "instituição econômica-adesão global da população a seu regime e a seu sistema $(2008$, p.113, 114, 115).

$\mathrm{Na}$ América Latina, as mudanças aconteciam em um cenário no qual as economias se caracterizavam por ter níveis de inflação incontroláveis, grande endividamento externo e distribuição de renda altamente desigual. Frente a esta conjunção de fenômenos, a solução passaria por diminuir o gasto público e, com isto, reduzir os salários e controlar o crédito, implementar políticas de preços relativos e aplicar políticas de reforma financeira. A resultante foi a queda dos salários reais, pior distribuição de renda, maior desigualdade e elevados ritmos inflacionários (DI LORENZO; SUAREZ, 2010).

Desta forma, o modelo de acumulação keynesiano-fordista é substituído pelo modelo neoliberal, que implica em uma redefinição política das formas de intervenção do Estado referentes ao desenvolvimento e bem-estar social (BARAIBAR, 2009). Assim, nos anos 90, apresentaram-se indícios de uma reforma do Estado que obedecia a fundamentos macroeconômicos, motivados pela necessidade urgente de aplicar medidas que permitiram a estabilização da economia.

De acordo com Polanyi:

Los pioneros del absolutismo económico soñaron con una sociedad sin trabas para el comercio de modo que viviese al ritmo marcado por el desarrollo de un mercado autorregulador. Pero este pilar central del credo liberal [...] dejó a las sociedades a merced de los vaivenes imprevisibles provocados por la especulación, el afán de lucro y la libre competencia en los negocios. Por primera vez en la historia de la humanidad la sociedad se convertía en una simple función del sistema económico y flotaba sin rumbo en un mar agitado por las pasiones y los intereses, como un corcho en medio del océano $^{33}$ (POLANYI , 1989, p. 17).

Mesmo que cada país apresente características específicas, razão pela qual mais adiante se abordarão especificamente o caso brasileiro e o equatoriano, as transformações ocorridas a partir da inserção das novas políticas foram similares em todos os países latino-americanos. Trata-se de países que finalizam seus períodos

\footnotetext{
${ }^{33}$ Tradução livre da pesquisadora - Os pioneiros do absolutismo econômico sonharam com uma sociedade sem travas para o comércio, de modo que vivesse ao ritmo marcado pelo desenvolvimento de um mercado autoregulador. Porém, este pilar central do credo liberal deixou a sociedade à mercê dos vaivéns imprevisíveis provocados pela especulação, o desejo do lucro e a dupla competência nos negócios. Pela primeira vez na história da humanidade, a sociedade se convertia em uma simples função do sistema econômico e flutuava sem rumo em um mar agitado pelas paixões e pelos interesses, como uma cortiça no meio do oceano.
} 
ditatoriais e transitam pela nova democracia, com desequilíbrios econômicos e décadas perdidas, instabilidade e violação de direitos individuais, coletivos e sociais, desregulamentação da economia, liberalização comercial e reestruturação produtiva selvagem, subserviente, subterrânea e sem parâmetros de legalidades (CACCIAMALI E JOSÉ-SILVA, 2003).

Entre as principais semelhanças, encontra-se a adoção, pelo menos parcialmente, das recomendações estabelecidas em 1989 no Consenso de Washington e seus posteriores efeitos. Porta-vozes da ideologia neoliberal: o Fundo Monetário Internacional, o Banco Interamericano de Desenvolvimento e o Banco Mundial junto com o governo americano convocaram, em 1989, especialistas nas diversas áreas da economia para avaliar as reformas empreendidas na América Latina e construir novas orientações em prol de maior desenvolvimento.

As recomendações elaboradas sintetizam-se em dez itens principais: disciplina fiscal, redução dos gastos públicos, reforma tributária, taxas de juro, taxas de câmbio, abertura comercial, investimento estrangeiro direto, privatização, desregulamentação e direito da propriedade intelectual (WILLIAMSON, 1990). As medidas convergem para dois grandes resultados: por um lado, a drástica redução do Estado; e por outro, o máximo de abertura à importação de bens e serviços e à entrada de capitais de risco, sob os supostos de soberania absoluta do mercado autorregulável nas relações econômicas internas e externas.

A respeito disso, resulta relevante a reflexão de Nogueira Batista quando expressa:

\begin{abstract}
A presunção do Consenso de Washington pareceria ser a de que os países latino-americanos teriam condições de competir na exportação de produtos primários para os quais possuíssem uma vocação natural e/ou em produtos manufaturados sobre a base de mão-de-obra não qualificada de baixos salários. Como se fosse possível ou desejável perpetuar vantagens comparativas baseadas numa situação socialmente injusta e economicamente retrógrada e, ao mesmo tempo, enfrentar as visíveis nuvens negras do protecionismo que começam a se esboçar no horizonte dos mercados dos países desenvolvidos, em nome do que já classificam de "dumping social" (NOGUEIRA BATISTA; 1994).
\end{abstract}

No trânsito de uma sociedade tradicional a uma sociedade moderna, a década de 90 representou um período de teste, ensaio e erro. Foi a década em que América Latina escutou todas as recomendações vindas de fora e as testou. Momentos de expectativa e conflito entre os que defendiam as reformas e os que exigiam que elas 
fossem definitivamente retiradas das agendas públicas. Assim, ao longo de aproximadamente dez anos, se procurou aplicar com vigor o conjunto de políticas econômicas que constituíam o Consenso de Washington, porém os resultados estiveram abaixo das expectativas (MATHEWS E HAKIM, 2002), motivando a aquisição de novas estratégias para gerir a questão social.

Desta forma, a conjunção de fatores tais como: as recomendações provenientes das organizações internacionais, o desmonte do Estado de bem-estar social na Europa e seus efeitos na América Latina, e a conformação de novos grupos de poder (Estados Unidos, Europa e o Sudeste Asiático) fragilizaram a autonomia conquistada pelos Estados nacionais em relação às suas políticas econômicas, colocando-os em uma situação de dependência que predominará nos anos subsequentes. Neste sentido, é possível afirmar que se estava frente a um modelo híbrido, no qual convivem serviços semiprivatizados, com outros nos que se acentua a intervenção estatal, que requerem a participação mista de atores, públicos e privados (MIDAGLIA E ANTÍA, 2007).

Em ocasião da pesquisa em curso, interessa analisar os efeitos que o novo cenário traz para o mundo do trabalho, já que este constitui e explica grande parte da sociedade capitalista. De acordo com Cattani, as facetas essenciais do processo de socialização, da construção da identidade, das formas de dominação e resistência e, em geral, da dinâmica contraditória da economia de mercado, encontram sua origem nas situações laborais e nas relações sociais estruturadas no seio da atividade produtiva (CATTANI, 2000).

Entretanto, a relação entre capital e trabalho e destes com a força produtiva tomaram diferentes formas desde que o feudalismo é substituído pelo capitalismo. Na continuação, analisar-se-á o caso da América Latina e, em especial, do Brasil e do Equador.

\section{AS NOVAS DETERMINAÇÕES DO MUNDO DO TRABALHO}

Com o avanço do capitalismo, os Estados conseguiram, pelo menos parcialmente, a estabilidade monetária e a melhoria das condições gerais de competitividade internacional. Porém, acarretaram efeitos menos positivos tais como a permanência e aumento da desigualdade social, o desemprego e o subemprego, 
os quais alcançaram níveis altamente desalentadores, sendo este um dos principais efeitos deste novo período que coloca a América Latina em um quadro de desregulamentação, de informalização e de flexibilização do mercado de trabalho, que se estenderá pelos anos seguintes.

Entre as características mais conhecidas do mundo do trabalho do capitalismo atual, Meneleu Neto (1998) recolhe seis que dariam conta das principais mudanças. São elas: desemprego crescente, com desregulação do mercado de trabalho e aumento da incerteza; aumento das mulheres na PEA; aumento dos trabalhadores em tempo parcial, com contratos de trabalho não padronizados e/ou precários; queda da taxa de sindicalização e/ou não reconhecimento dos sindicatos; expansão do individualismo e declínio da ética da ação coletiva e desemprego juvenil crescente, informalidade e economia subterrânea marginal. Este conjunto de mudanças constitui um processo de maior heterogeneização, fragmentação e complexificação da classe trabalhadora, no qual, por um lado se reduz o operariado industrial e por outro, aumenta o subproletariado, o trabalho precário e o assalariamento no setor dos serviços (ANTUNES, 1995).

Somado a estas mudanças, e talvez produto delas, as taxas de desemprego aumentaram significativamente nos anos 90 , e se aprofundaram no fim da década, apresentando um crescente exército de desempregados no fim do século $X X$, mesmo que amortizado pelo mercado informal (MENELEU NETO, 1998). Argentina, Brasil, Chile, Colômbia e Equador elevaram seus índices de informalização no mercado de trabalho e reduziram a proporção de assalariados no emprego, obtendo como resultado uma taxa de desemprego na região que passou de 8,0\% em 1998 para $8,7 \%$ no ano seguinte, representando a maior taxa de desemprego da década de 90 .

Segundo a lógica capitalista, o desemprego faria parte de um processo de ajuste estrutural, que se deriva da introdução das novas tecnologias; ou seja, é visto como algo natural. No entanto, o desemprego na forma que adquiriu nas economias dos países periféricos excede os limites do "aceitável" até para o capitalismo, e se não se encontrar uma alternativa, pode afetar o ciclo virtuoso da produção e do lucro. Se a população não conta com salario, não poderá acessar aos bens e serviços que dão vida ao capitalismo.

Meneleu Neto explica que: 
Foi nessa tentativa de superar o impasse do lucro que a politica economia sofreu a "virada" neoliberal, tendo a perspectiva de criar as condições para a reestruturação capitalista global. Assim, podemos dizer que os condicionantes tecnológicos, tidos como inevitáveis e dotadas de uma objetividades pura e natural, são produzidos pelo sistema como tentativa do chão de fábrica. Trata-se de recolonizar a base material através da forma social capitalista, de reanimar o espirito vital do capital em busca de lucratividade. Essa recolonização encontrou nos poderoso sindicatos operários 0 principal obstáculo às suas pretensões. Portanto, no caso do trabalho organizado, a fragilização dos sindicatos passa a se constituir como um requisito para a reestruturação do poder do capital (MENELEU,1998, p. 79).

A palavra de ordem neste momento é desregulamentação. No nível macro, quando o Estado libera as fronteiras para o capital permitindo a implantação da modernização; no nível micro, o capital produtivo também exige um mercado de trabalho desregulamentado, de forma que a força de trabalho desprotegida pelo Estado e débil enquanto coletivo fosse absorvida pelo capital sob suas condições.

Nesse sentido, a existência de um exército industrial de reserva de grande porte enfraqueceu o poder de associação dos operários, fazendo com que decaia o poder de resistência. O medo de perder o emprego, a forma mais "digna" de sobreviver, reduz as flutuações e estimula maior disciplina do trabalho, maior atenção, maior esforço, significando também menor possibilidade de luta (MANDEL, 1982; CATTANI, 2000). A nova força de trabalho a ser empregada é mais simples de ser admitida e mais fácil de ser demitida.

Assim, é possível observar como o trabalho organizado se fragiliza, cedendo espaço para um mercado de trabalho flexível, "onde não parece haver lugar para conflitos coletivos ou posições ideológicas" (MENELEU NETO, 1998, p. 89). O trabalho parcial, precário, temporário, terceirizado, vinculado à economia informal representa a nova realidade da classe trabalhadora que, além de precarização das condições de emprego e diminuição do valor de sua força de trabalho, traz também regressão dos direitos sociais e ausência de proteção e expressão sindical, levando à individualização extrema da relação salarial (ANTUNES, 1995; BIHR, 1998).

No mesmo caminho, o não trabalho assume um papel fundamental, pois é o trabalho assalariado, que desde que foi concebido como elemento fundamental na vida das pessoas, coloca os cimentos para a reprodução social. Transformou-se em um fator básico de socialização, na atividade principal e em um elemento definidor do sentido da vida dos indivíduos e por tanto, se constitui em um elemento 
explicativo dos problemas e das tendências de transformação econômica e social (CATTANI, 2000).

Deixar de formar parte do grupo dos trabalhadores assalariados traz consequências que vão muito além da falta de salário, tem a ver com o status social de cada indivíduo e com a forma de se colocar na sociedade. Nestas condições, o capitalismo falha. A crença de que este sistema absorveria o número crescente de trabalhadores deslegitimou-se e a economia de livre mercado definitivamente não consegue proporcionar condições de trabalho e de vida digna para a população em condições de trabalhar. Assim, os indivíduos "têm a opção de se 'acomodarem à liberdade'. Os mais capazes e empreendedores sobreviverão; os incapazes e inadaptados serão eliminados pela lei da seleção da espécie" (CATTANI, 2000, p.63).

Nesse sentido, pode-se afirmar que a relação emprego/desemprego que se pode estabelecer no século XXI difere das que podiam se observar na segunda parte do século XX. A mudança no modelo de desenvolvimento alterou a forma de organização do trabalho, o valor do trabalho, a organização das relações laborais, internalizando os princípios estruturais da modernização neoliberal, isto é: a individualização não assistida e o mercado como mecanismo de coordenação social (FIGUEROA, 2003).

Com base nessas questões gerais, apresenta-se mais um grande desafio: para que o sistema siga funcionando, são necessárias certas condições de que o mercado não dispõe e dentre elas está a ação do Estado. O processo de acumulação capitalista em escala ampliada "requer certas condições sociais para manter a reprodução dos pressupostos do sistema: de um lado, a classe dos 'vendedores da força de trabalho', e de outro, a classe dos 'possuidores do capital'." (MENELEU NETO, 1998, p. 83).

Assim, as sociedades contemporâneas contam com um amplo "exército industrial de reserva", na concepção de Marx; uma "classe que vive do trabalho", na concepção de Antunes; ou um grande contingente de desafiliados e excluídos, na visão de Castel, que precisa ser atendido.

Frente a este cenário, o Estado intervém por meio de políticas públicas que adquirem características diferentes a adotadas a partir da década de 1940, quando o seu papel era principalmente o da tutela em suas diversas manifestações. $O$ fim do século $X X$ e a primeira década do século $X X I$ exigem uma nova função: a de não 
deixar morrer. Para isto, duas estratégias são utilizadas: por um lado, inicia um período de elaboração de políticas públicas focalizadas, descentralizadas e terceirizadas que garantem a sobrevivência da força de trabalho; e por outro e de forma simultânea, apela para a responsabilidade partilhada de diversos atores para concretizar essas políticas. Dentre estas, reaparece e sobressai a responsabilidade do trabalhador pela sua própria condição.

A combinação destes elementos apresenta um novo cenário: um estado social liberal que precisa criar novas estratégias de produção e reprodução da força de trabalho, assim como novas formas de governar. Neste contexto, após abordar as principais características das políticas emergentes na América Latina, no Brasil e no Equador, e analisar a constelação de agentes que fazem possível sua implementação, no capítulo 3 se estudará se a Economia Solidária resgatando experiências de cooperativismo, associativismo e autogestão, e agregando a intervenção técnica e financeira do Estado (para sua operacionalização) pode ser entendida como uma dessas estratégias.

\section{A INTERVENÇÃO DO ESTADO E O NOVO ENFOQUE DAS POLÍTICAS PÚBLICAS NA AMÉRICA LATINA}

\subsection{A focalização e o sentido público do ser social}

Das três estratégias principais que se observam no processo de mudança da política pública, a focalização foi a que ganhou maior centralidade. A pretensão universalista que cruzava as concepções de política pública desde seus primórdios, viu-se amplamente afetada no momento em que os governos tiveram de combinar o fenômeno da recessão econômica com o investimento social. Esta equação dificilmente daria certo, porém não se pouparam esforços para legitimá-la. Os defensores do neoliberalismo conheciam os impactos que esse tipo de política causaria e sabiam dos custos sociais que acarretariam. No entanto, manifestavam que recuperado o dinamismo do mercado, haveria um círculo virtuoso que traria consigo a melhora dos níveis de vida de toda a população. Os anos se passaram e a ingenuidade neoliberal ficou em evidência.

Finalmente, acabou resultando no esquecimento do ideal universalista, gratuito e igualitário dos serviços públicos, e no seu lugar, enfatizou-se a elaboração 
de programas sociais que, mesmo sem criar políticas que garantissem o pleno direito, compensassem os efeitos produzidos pelo Estado Mínimo.

As mudanças que podem ser observadas nas políticas sociais elaboradas e implementadas pelos países da América Latina parecem ser resultado da necessidade de operacionalização do novo Estado e do novo modelo econômico. Elas compatibilizam as necessidades de mudança na ordem econômica com a estrutura arcaica e conservadora das práticas políticas históricas das elites latinoamericanas (PINHEIRO, 1995).

Desta forma, as políticas sociais adquirem a forma descentralizada e focalizada, e sua administração deixa de ser centralmente comanda pelo Estado e passa a ser conduzida por uma constelação de agentes.

Dentre as grandes características mencionadas, a focalização é a que mais se destaca e gera apreciações diversas. Esta se realiza a partir da concentração de recursos disponíveis em uma população de beneficiários potenciais, e da elaboração de programas por meio dos quais se pretende atender um determinado problema ou necessidade insatisfeita, levando-se em conta as características dessa população, objetivando a elevação do impacto ou benefício per capita (CEPAL, 1995).

Os aspectos estritamente operativos desta concepção são os que apresentam mais aceitação, embora também possam ser criticados. No entanto, as maiores debilidades se encontram na análise da dimensão política que há por trás desta questão.

Operativamente, a focalização apresenta uma alternativa eficaz no que se refere à diminuição do gasto público, já que políticas especificamente dirigidas a um grupo têm custo menor que as que se pretendem universais. Ao focalizar a atenção nos grupos de baixa renda, pode-se presumir que haveria uma tendência a corrigir certas iniquidades distributivas, enquanto as políticas permitiriam a elevação do nível de vida das pessoas que se encontram em piores condições, atendendo de forma diferenciada as realidades diversas.

Entretanto, os mesmos aspectos que podem ser vistos como positivos, apresentam ressalvas. $O$ fato de pertencer a um grupo beneficiário pode estimular a manutenção do status de vulnerável, já que isto Ihe confere a possibilidade de permanecer com o benefício, e desta forma, a pobreza deixa de ter uma identidade transitória para ter uma identidade terminal, pois isto lhe garante a permanência na condição de credor do bem proporcionado (BARAIBAR, 2009). 
Como se pode constatar, na América Latina há um espectro de situações de pobreza, não existem apenas os extremadamente pobres. Existem também os pobres e os que em breve poderão estar nessa condição.

Um exemplo recorrente são os benefícios relativos à educação e à saúde. Programas que apresentam uma série de benefícios educativos, como o acesso a cursos de capacitação, a qualificação profissional, entre outros, se limitam a atender um grupo que, de tão específico, torna-se absolutamente homogêneo, eliminando as possibilidades de interagir e formar grupos diversos, primando o sucesso individual e aniquilando toda e qualquer possibilidade de integração. Além de muitas vezes se dirigir a grupos que não se interessam em participar, e deixa desamparados outros que apresentam maiores condições de aproveitar os recursos oferecidos.

Podem-se observar em muitos países da América Latina reformas da saúde que criam interação entre o setor público e o setor privado, reduzindo o acesso ao primeiro pelos grupos com renda mínima ou sem renda, sem contemplar os que ficam nas franjas intermediárias, havendo uma grande mercantilizando dos serviços de saúde. Exemplos como esses dão conta de uma grande fragilidade deste tipo de políticas que descuidam um amplo grupo de pessoas que facilmente reduzirão seus níveis de vida, se não lhes confere certo tipo de segurança relacionada a bens públicos.

Neste caso, pode-se observar a elaboração de políticas relacionadas ao acesso ao mercado de trabalho e à capacitação profissional, à saúde e educação pública, assim como a promoção e garantia de direito de grupos tais como crianças, jovens, idosos e mulheres, indígenas e negros, que também adquirem relevância neste fim de século $X X$ e começo do século XXI. Por outro lado, há uma visível tendência constatada nos países da América Latina de agrupar essas ações em programas mais amplos de renda condicionada, que geralmente implicam na obrigatoriedade de participação nos diversos programas sociais do governo. Estes surgem especialmente com o intuito de dar resposta a situações de emergência, porém, têm-se instalado como mecanismos estáveis de política pública, consolidando-se como programas que propõem a superação da pobreza (BARAIBAR, 2009), de forma também focalizada. Nesse sentido, segundo Baraibar, politicamente a focalização encontra sustento em duas ideias: a de gravidade e a de diferenciação. É necessário ser (pessoal, familiar, institucional ou comunitariamente) desigual e gravemente diferente dos outros para acessar e permanecer no benefício 
(ibidem, 2003). Esta condição não faz mais que acentuar a desigualdade, criando situações permanentes quando se supõe que a intenção é incidir no emergencial, enquanto o próprio sistema geraria mecanismos para diminuir a desigualdade por meio do livre comércio, embora esta parte da fábula ainda não tenha sido constatada.

Desta forma, os dispositivos integradores que funcionaram historicamente são substituídos por políticas focalizadas que vêm para compensar a falha de um sistema incapaz de articular os diferentes grupos populacionais desde seus mecanismos globais de regulação (DUSCHATZKY E REDONDO, 2000). Nesse sentido, a população de baixa renda é colocada em um círculo de permanência e dependência constante com os programas sociais. Baraibar faz uma colocação muito pertinente ao expressar:

O vazio de experiências plurais, a fragilidade dos vínculos institucionais, a precariedade das ofertas culturais, e principalmente a pobreza material na qual vivem amplos grupos sociais faz com que os sujeitos se adiram -em ocasiões como aderência e não como adesão- a qualquer oportunidade que se instala com tal de não ficar por fora de todo âmbito de reconhecimento (BARAIBAR, 2003, p. 22).

Assim, as dimensões em questão extrapolam os aspectos operativos e requerem atenção desde um ponto de vista mais abrangente. Atrás de políticas focalizadas, há também focalização do sentido público do ser social. Há uma fragmentação de direitos que não pode se desconhecer, envolvendo uma intencionalidade que vai além de ações pontuais, e que reflete um acionar limitado e uma tendência a manter a situação de precariedade e desigualdade. Não se está frente a alternativas, se está diante de estratégias de contenção. Contenção esta que reflete um tipo de gestão da pobreza própria da era neoliberal, contribuindo com a perda de conquistas alcançadas e colocando ao conjunto de atores envolvidos, uma sorte de inércia pactuada.

Neste cenário marcado pela fragmentação social, a focalização dos programas sociais se instala como uma das chaves mágicas para atender os efeitos crescentes de uma sociedade cada vez mais dualizada (DUSCHATZKY E REDONDO, 2000). 
2.2 Da responsabilidade estatal à responsabilidade partilhada

Pode-se observar que no último decênio é comum, entre os países da América Latina, assistir a um movimento do Estado que pactua com novos agentes, principalmente em dois níveis: um nível institucional e um nível comunitário.

No nível institucional, se distinguem três agentes principais: organizações internacionais como o Banco Mundial, Banco Interamericano de Desenvolvimento e Agências da $\mathrm{ONU}$; corporações empresariais e organizações da sociedade civil, principalmente OSC. No nível comunitário, se enfatiza no papel das comunidades locais. Esta nova constelação de agentes promove a organização em rede e coloca especial ênfase na articulação entre o âmbito local, regional e internacional, permitindo contínuos processos interativos de adaptação e "neo-desenvolvimento".

A interação destes agentes conforma uma nova estrutura de poder a qual Lucia Bruno faz referência, expandindo a noção de Estado Amplo abordada por Bernardo (1998). A autora expressa que no fim dos anos 90 ,

Existe uma fonte de definição de objetivos globais, de organização
de instituições em escala mundial, de difusão de valores, de hábitos
de consumo (superando tradições e culturas locais), de normas
sociais e de mecanismos de controle da ação coletiva, que não
decorrem do estado tradicional, mas de uma estrutura de poder
comandada pelos maiores grupos econômicos (BRUNO, 1999. p.
38).

Nesse sentido, segundo Bruno, depois do Estado Nacional, o que se desenvolveu foi "uma estrutura de poder muitíssimo mais ampla, totalitária e totalizante, do que tudo que se conheceu na história do capitalismo" (1999, p. 40)

Neste trabalho, será descrito, de forma sucinta, o papel de cada uma delas nas sociedades capitalistas modernas, buscando mostrar suas relações, quando existentes, com a produção e reprodução da força de trabalho.

\subsubsection{O papel das organizações internacionais}

As organizações internacionais, entendidas como "associações voluntárias de Estados constituídas através de um Tratado, com a finalidade de buscar interesses comuns por intermédio de uma permanente cooperação entre seus membros" (SEINTENFUS; VENTURA, 1999, p. 87), surgem no século XIX motivadas por diversos fatores. Entre eles, identificam-se a necessidade de intervir em conflitos 
entre nações, incentivar o desenvolvimento das regiões mais carentes, criar normas internacionais e proteger os direitos humanos recentemente conquistados. Segundo Medeiros:

[...] parece óbvia a interferência das organizações na estrutura e na dinâmica da sociedade internacional contemporânea. Nascidas para atender a certas necessidades comunitárias, as organizações, [...] ensejam a passagem de uma sociedade interestadual fechada para uma sociedade aberta. Isto não significa, porém, que o desenvolvimento das organizações internacionais deva ser interpretado como expressão de um processo acelerado rumo à integração terminantemente orgânica e unitária do gênero humano em um "Estado Mundial" mas apenas que, tanto em seus elementos componentes (estrutura) como em suas formas de relacionamento (dinâmica), a sociedade internacional, basicamente interestatal, precisou retificar seu perfil clássico e ajustar-se [...] a uma nova realidade (MEDEIROS, 1994, p. 273).

No entanto, a dinâmica das organizações internacionais tende a ser a do imperialismo e a conquista, em um cenário onde o sistema capitalista gera dependências que não se limitam ao âmbito local.

O Banco Mundial se torna um agente importante justificando sua intervenção na necessidade de implementar "redes de segurança" ${ }^{34}$ nas quais investe amplamente. Neste sentido, interfere de diferentes formas nas reformas adotadas pelos Estados latino-americanos, fazendo com que estes deem prioridade ao funcionamento do mercado; mesmo que para isso seja necessário mudar os padrões comerciais e amortizar as barreiras existentes, além de erradicar as grandes pressões fiscais. Junto com isto, se promove a diminuição do gasto social, sob o lema de racionalização de recursos, e se exorta a estabelecer alianças estratégias com o setor privado.

Neste sentido, as políticas públicas são consideradas pelo Banco Mundial como formas de garantir que o crescimento seja compartilhado por todos e contribua para reduzir a pobreza e a desigualdade, devendo os governos atribuir prioridade aos setores sociais fundamentais (Banco Mundial, 2007). Tal orientação nada mais é do que a acentuação dos princípios de focalização analisados acima.

No tocante ao Banco Interamericano de Desenvolvimento, fundado em 1959 por um acordo entre os países interamericanos, sua função é de "contribuir para

\footnotetext{
${ }^{34}$ As redes de segurança fazem referência a uma estratégia utilizada pelo Banco Mundial na qual junto ao dinheiro emprestado aos países, proporciona-se assistência técnica e assessoramento em matéria de política econômica.
} 
acelerar o processo de desenvolvimento econômico e social, individual e coletivamente, dos países membros regionais em vias de desenvolvimento" (BID). Sendo a maior fonte de financiamento para o desenvolvimento na América Latina e Caribe, dispõe de recursos financeiros e técnicos através dos quais intervém na formulação de políticas públicas. Com diretrizes claras, condiciona o financiamento à realização de práticas que muitas vezes resultam inadequadas para o país em questão, já que mesmo compartilhando histórias comuns a América Latina conserva sua diversidade. Neste sentido, cada nação se identifica com caraterísticas próprias que a fazem diferente e, por tanto, os problemas também requerem atenção diferenciada, invalidando as receitas prontas. Neste sentido, Behring (2002) considera que os empréstimos internacionais acabam sendo subsídios políticos voltados para a garantia da ordem capitalista mundial, contendo impulsos revolucionários alimentados pela crescente e trágica pauperização das populações dos países desenvolvidos.

Nesta mesma linha de análise, encontram-se as Agências da ONU que intervém diretamente na formulação de políticas sociais em diversas áreas. Organizações tais como UNICEF, OIT, UNESCO, UNDOC, PNUMA, entre outras, são responsáveis por pesquisar e diagnosticar a situação em suas áreas específicas de conhecimento e intervenção e têm o papel de definir ações concretas para contribuir com o desenvolvimento das nações, promovendo parcerias entre os Estados, as instituições, a comunidade e os indivíduos.

Segundo Baraibar, as organizações internacionais:

Actúan a nivel intelectual, ya que adquieren una posición de liderazgo, tanto en la producción de datos como de herramientas conceptuales. También operan a nivel de la acción directa, en tanto el acceso a la ayuda financiera queda condicionada por la toma de iniciativas de lucha contra la pobreza y no solo por la adopción de las reformas. En un contexto de crisis financiera, los gobiernos salen a la caza de estos fondos, adoptando el punto de vista de los proveedores $^{35}$ (BARAIBAR, 2009, p. 162).

Neste contexto, os organismos internacionais regulam as relações econômicas e políticas, e definem estratégias institucionais capazes de garantir o controle de decisões inter e intranacionais. As nações são levadas a aderir às regras

\footnotetext{
${ }^{35}$ Tradução livre da pesquisadora - Atuam em nível intelectual, já que adquirem uma posição de liderança, tanto na produção de dados como de ferramentas conceituais. Também operam em nível da ação direta, entretanto o acesso à ajuda financeira fica condicionada pela tomada de iniciativa de luta contra a pobreza e não só pela adoção das reformas. Em um contexto de crise financeira, os governos saem à caça destes fundos, adotando o ponto de vista dos provedores
} 
do jogo para ter acesso aos benefícios prometidos. No caso de não adesão, renuncia-se à "proteção" do sistema (FONSECA, 1998).

Desta forma, na nova conjuntura, os Estados Nacionais ficam com poucas possibilidades de se mobilizar, estabelecem alianças que nem sempre são estratégicas e se enfraquecem enquanto formuladores de políticas públicas.

\subsubsection{O papel das corporações empresariais}

As primeiras ações coletivas das empresas datam do século XVIII e XIX, relacionadas às ações de caridade para enfrentar os efeitos da pobreza, que despertava sentimentos de piedade mais do que questionamento sobre direitos sociais. O empresariado, neste caso, era motivado geralmente por preceitos morais e religiosos. No dizer de Geremek "a atividade filantrópica, traduzindo o desejo humanitário de socorrer outrem, permite que o benfeitor mostre a sua riqueza e afirme publicamente o seu prestígio social" (1986, p.16).

O panorama muda significativamente com o advento do neoliberalismo, quando aquelas estratégias remotas de algumas empresas se tornam uma prática comum entre o corporativismo. A responsabilidade que se desencadeava em ações pontuais de "ajuda" passa a ser ampliada em termos de responsabilidade social empresarial, onde o negócio é incluído na relação.

Segundo Boltanksi e Chiavello

O capitalismo não pode prescindir de uma orientação para o bem comum da qual extrai as razões pelas quais vale à pena aderir a ele. No entanto, sua indiferença normativa impede que o espírito do capitalismo seja gerado a partir dos seus próprios recursos. Deste modo, o capitalismo necessita da ajuda de seus inimigos, aqueles que se indignam e se opõem a ele, para encontrar os pontos de apoio morais que lhe faltam, e incorporar dispositivos de justiça, elemento sem os quais não disporia da menor propriedade (BOLTANSKI E CHIAVELLO, 2002 apud COSTA, 2006, p.100)

Neste sentido, seria natural pensar que se as reformas neoliberais vieram para acelerar o crescimento econômico, dinamizando o mercado, abrindo as economias ao comércio, liberalizando os sistemas financeiros e até privatizando empresas estatais, o setor corporativo se veria altamente beneficiado e deveria oferecer uma contrapartida. $O$ fato é que com ou sem essa consciência, paulatinamente o papel das empresas foi incorporado na gestão da questão social, 
fundamentalmente por meio de duas grandes estratégias: interna e externa. A primeira trata-se, grosso modo, de ações realizadas no interior das empresas que procuram oferecer melhores condições laborais e de vida para os funcionários e suas famílias, o que redundaria em melhor desempenho e produtividade do trabalho. Também se incluem nesta estratégia, os programas de voluntariado dos quais participam os funcionários, dirigidos especialmente a apoiar ações de OSC, escolas, postos de saúde, entre outros.

As estratégias externas geralmente apoiam iniciativas provenientes do governo ou de organizações e grupos não governamentais, em instâncias referentes à alocação de recursos para desenvolvimento de programas e projetos sociais. Desta forma surge o conceito e a prática da parceria público-privada que teve início na Europa na década de 1990 e se debruçou pelo território latino-americano com maior ênfase a partir do início do século XXI. A mencionada parceria envolve a utilização de recursos privados para que o Estado atinja seus objetivos e assim permite que o setor privado realize negócios em atividades que corresponderiam ao setor público. Desta forma, o mecanismo que assegura a parceria é a garantia prestada pelo setor público ao setor privado sob suas possibilidades de retorno (PASIN e BORGES, 2003).

É importante destacar que quando o apoio é diretamente para o setor não governamental, há uma tendência recorrente a apoiar práticas que apresentem consonância com as políticas públicas que são implementadas em nível local e nacional. Desta forma, o Estado e o mercado se complementam na execução de funções públicas, colocando seus princípios em exposição e suas regras a disposição.

Podem ser observados comportamentos comuns entre empresas do mesmo ramo de atividades. Exemplo disso são os bancos que em geral tendem a apoiar instituições educacionais e/ou culturais, criando Fundações e Institutos que se financiam com recursos das instituições financeiras que lhe deram origem. Exemplos disto são: a Fundação Bradesco, o Instituto Cultural Banco do Brasil, a Fundação Itaú Cultural, o Instituto HSBC, dentre outros que atuam na América Latina. Outras áreas que comumente são escolhidas para apoiar projetos são saúde, emprego (principalmente no que tem a ver com capacitação e profissionalização) e mais recentemente as referentes ao meio ambiente. Destacam-se fundações tais como: Coca-Cola, Volkswagen, Mitsubishi, Ford, Telefônica, Avina, Codespa, Rockefeller e 
Friedrich Ebert, entre outras. Esta atuação se dá também em consonância com as diretrizes das organizações internacionais assinaladas acima, já que Segundo o Banco Mundial: "El Estado es fundamental para el proceso de desarrollo económico y social, pero no en cuanto agente directo del crecimiento, sino como socio, elemento catalizador e impulsor de ese proceso" ${ }^{36}$ (Banco Mundial, 1997, p.1).

Segundo Bruno:

Devemos compreender a máxima neoliberal de que o mercado tudo conduz e organiza. Este mercado de que tanto se fala não é outra coisa senão 0 poder dos grandes grupos econômicos transcionalizados, de planejar e coordenar a economia em nível global, exercendo, por aí, as funções coercitivas e repressivas antes a cargo do Estado clássico. Neste novo quadro, o Estado Nacional, tal como existiu até os anos noventa, tornou-se supérfluo para as classes capitalistas (BRUNO, 1999, p. 40).

Neste sentido, independentemente de que algumas destas novas alianças possam dar certo e outras serem nitidamente inviáveis, é imprescindível ser cuidadoso na hora de difundir novas ideias sobre as funções do Estado e do mercado para não cair em simplificações. Segundo a visão do autor desta pesquisa, a função do mercado não é a do Estado, mesmo este desprovido e quebrantado, nem vice-versa.

\subsubsection{O papel das organizações da sociedade civil}

Quando se trata de prestação de serviços públicos, um agente que se apresenta impetuosamente, além dos já mencionados, são as organizações da sociedade civil, conglomeradas no chamado terceiro setor que inclui as mais diversas entidades privadas com fins públicos. Sem querer ignorar as múltiplas diferenças que existem entre estas instituições, para efeito deste trabalho serão todas entendidas como organizações da sociedade civil, doravante OSC, pois o conceito é abrangente o bastante para dar conta do grande espectro de particularidades que as caracteriza.

Feito este esclarecimento, cabe salientar que estas são um agente fundamental na administração da atual questão social, apresentando uma nova forma de se relacionar com o Estado. Mesmo que nesta metamorfose se haja

\footnotetext{
${ }^{36}$ Tradução livre da pesquisadora - O papel do Estado é fundamental para o processo de desenvolvimento econômico e social, porém não enquanto agente direto do crescimento senão como sócio, elemento catalisador e impulsionador desse processo.
} 
perdido parte daqueles princípios constituidores, vale dizer o seu caráter de politização e mobilização da população pobre, com um papel contestatório, inspirado na luta pela igualdade e pelo efetivo cumprimento dos direitos humanos, em suas diversas manifestações.

Na América Latina, as primeiras OSC surgiram sob a forma de Organização Não Governamental (ONG) na década de 50, principalmente a partir de grupos religiosos, empresariais e profissionais que realizavam ações filantrópicas, e de caráter principalmente assistencial, paralelamente às ações dos Estados, considerando que na época havia presença de políticas sociais estatais nestes territórios. Assim, foi se conformando o que seria um novo setor que velaria pelo bem-estar da população mais empobrecida. Posteriormente, nos anos 60 e 70, a motivação pela assistência aos mais necessitados começa a ser complementada (ainda não substituída) pelo ímpeto da organização popular, através de práticas educativas que já plantavam as sementes da participação comunitária, embora timidamente.

Os anos 70 e princípio dos 80 foram de mudanças radicais para os países latino-americanos, muitos dos quais atravessaram intensos processos ditatoriais que pretendiam limitar qualquer tipo de manifestação e ação pública não estatal. No entanto, foi nesse momento que as OSC tiveram seu auge. Já na década de 80 , passam por um processo de institucionalização intervindo em novas áreas de trabalho, entre as quais se destacam os direitos humanos e as vinculadas às relações de gênero. A análise realizada por Balbis mostra como essa passagem foi acontecendo no decorrer dos anos 80:

La etapa de redemocratización que arranca por entonces en toda la región creó nuevos espacios y oportunidades en el ámbito de la gestión local y en el planteamiento de políticas alternativas de desarrollo en medio de una gran crisis económica general asociada con la problemática del pago de la deuda externa latino-americana y con el paulatino avance de modelos de acción gubernamentales de corte neoliberal materializados en políticas de "ajuste estructural". Alejadas ya, en muchos casos, de prácticas asistenciales, desarrollistas o de esquemas teóricos dogmáticos, se crean por entonces instituciones que buscan alternativas de salida de la crisis desde la relación directa con los sectores populares, con mecanismos de funcionamiento más complejos, sistematizados y de menor grado de improvisación ${ }^{37}$ (BALBIS, 2001, p. 20).

\footnotetext{
${ }^{37}$ Tradução livre da pesquisadora - A etapa de redemocratização que começa naquele tempo em toda a região criou novos espaços e oportunidades no âmbito da gestão local e na projeção de políticas alternativas de desenvolvimento em meio de uma grande crise económica geral associada com a problemática do pagamento da dívida externa latino-americana e com o paulatino avanço de modelos de ação governamental de corte
} 
Nos anos 90, o mercado, que estava ganhando espaço em todos os âmbitos, também influenciou a prática deste tipo de organização, contribuindo para uma significativa perda do sentido ideológico que thes deu origem. Sendo enxergadas pelas cooperações internacionais e pelo governo como potenciais agentes para a implementação de políticas sociais, as organizações sociais iniciam a empreitada de receber, além de recursos, diretrizes claras de atuação. As áreas de intervenção começam a mudar, criando novos nichos de atuação, destacando-se o setor das microfinanças e o desenvolvimento de estratégias para a geração de emprego e renda.

As grandes corporações empresariais e as agências de cooperação internacionais deixam de considerar o Estado como o principal gestor do desenvolvimento e começam a focar seus investimentos no setor privado não estatal, procurando formas mais democráticas de boa governança (BALBIS, 2001). O Banco Mundial colocará que as OSC têm "una función vital en la promoción de gobiernos responsables, entre otros motivos, por su contribución a la construcción de sistemas institucionales más pluralistas" ${ }^{38}$ (BANCO MUNDIAL, 1993 apud BALBIS, 2001, p. 23).

Mesmo com estas considerações, nas últimas três décadas, se costuram fios que aproximam, mais do que dividem, o Estado e as OSC, apresentando novos comportamentos de ambos os setores. De acordo com Souza Medeiros:

As novas perspectivas que se abrem com essa aproximação das
ONGs com o poder público variam desde a criação de fundos ou
programas que, em muitos casos, financiam o trabalho desenvolvido
pelas ONGs até a criação de novos espaços de participação política
com o objetivo de incorporar estes grupos nos processos que
envolvem a formulação elou implementação de políticas públicas
(SOUZA MEDEIROS, 2007, p. 167).

Estes novos agentes se tornam coadjuvantes do desenvolvimento imposto pelo modelo neoliberal, e é através deles que se leva adiante uma das caraterísticas constitutivas do tripé do novo modelo de políticas: a terceirização. Trata-se de um deslocamento das funções do Estado para as organizações da sociedade civil, sob o

neoliberal materializados em políticas de "ajuste estrutural". Distanciadas, em muitos casos de práticas assistenciais, desenvolvimentistas e de esquemas teórico-dogmáticos, se criam instituições que procuram alternativas de saída da crise desde a relação direta com os setores populares, com mecanismos de funcionamento mais complexos, sistematizados e de menor grau de improvisação.

${ }^{38}$ Tradução livre da pesquisadora - Uma função vital na promoção de governos responsáveis, entre outros motivos, pela sua contribuição de sistemas institucionais mais pluralistas. 
acordo de que estas são mais aptas para abordar a população alvo das políticas. Entre essas competências encontram-se: a experiência e especialização para trabalhar com grupos em situação de vulnerabilidade, aproximação com o público beneficiário, flexibilização dos processos participativos, entre outros. Neste sentido, Bresser Pereira e Cunill (1998) colocam algumas das questões que justificariam a implementação de políticas sociais estatais por parte de instituições não estatais.

La razón más importante para recurrir a las entidades sin fines de lucro no es porque sean más eficientes en la provisión de servicios de lo que pudiera ser cualquiera otra entidad, sino porque permiten desplegar roles que ni el Estado ni el mercado pueden cumplir. Y así como la confianza, la dedicación, la solidaridad constituyen roles que les imprimen una especificidad respecto del sector lucrativo, la flexibilidad, la disposición de experiencia especializada y la habilidad para acceder a clientes difíciles de alcanzar son exhibidas como algunas de las mayores ventajas que el sector no lucrativo o público no estatal tendría respecto al sector público estatal"39 (BRESSER PEREIRA E CUNILL, 1998, p. 43).

Entre essas potencialidades que se pode atribuir a essa transferência de funções encontram-se, segundo os autores mencionados, três grandes vantagens dessa associação: (1) A pluralização da oferta de serviços sociais - isto implicaria na ampliação de serviços, programas, projetos, e o aumento da qualidade e eficiência dos mesmos, entretanto teriam que concorrer a outras organizações para usufruir do benefício financeiro; (2) Flexibilização e desburocratização da gestão social entende-se que as organizações do terceiro setor contam com serviços administrativos e financeiros menos burocratizados, permitindo serviços mais ativos e adaptáveis às necessidades da população alvo; (3) Responsabilidade dos dirigentes e participantes pela organização - presume-se que os gestores e equipes técnicas das organizações do terceiro setor tendem a ser mais responsáveis com a gestão dos serviços do que o seriam as equipes estatais (BRESSER PEREIRA E CUNILL, 1998).

No teoria, as etapas de desenho, planejamento, execução e avaliação das políticas sociais seriam, no atual modelo, realizadas de maneira compartilhada,

\footnotetext{
39 Tradução livre da pesquisadora - A razão mais importante para recorrer às organizações sem fins lucrativos não é porque sejam mais eficientes na provisão de serviços do que poderia ser qualquer outra organização, senão porque permitem desenvolver papeis que nem o Estado, nem o mercado podem cumprir. $E$ assim, a confiança, a dedicação, a solidariedade constituem papeis que lhes imprimem uma especificidade a respeito do setor lucrativo, a flexibilidade, a disposição de experiência especializada e a habilidade para acessar a clientes difíceis de atingir, são exibidas como algumas das maiores vantagens que o setor não lucrativo ou público não estatal teria respeito ao setor público estatal.
} 
principalmente entre as organizações governamentais e não governamentais, e também controladas por elas. Na prática, a dinâmica mostra que a fase na qual as organizações não governamentais majoritariamente intervêm é a etapa de execução, que se faz com recursos públicos e internacionais, aos quais se acede por meio de convênios e projetos. No entanto, na etapa de desenho, se bem que ainda é principalmente planejada em instâncias governamentais, vem sendo incorporada, cada vez com mais interesse, à atuação do setor não governamental, aumentando a participação em processos decisórios, embora ainda não tenha um papel fundamental na definição das agendas.

O processo de avaliação também sofreu modificações integrando as diferentes esferas. Nos últimos anos, incorporou-se uma ideia que concebe os usuários das políticas sociais como informantes qualificados em relação ao alcance e resultados das políticas e, nesse sentido, suas avaliações adquirem importância. Além disto, espera-se que as instituições públicas e privadas se controlem mutuamente. Trata-se de pôr em prática um sistema de accountability horizontal de acordo com a concepção do cientista político Guillermo O'Donnell, que consiste na:

Existencia de instituciones estatales que tienen el derecho y el poder legal de, y están fácticamente dispuestas y capacitadas para, emprender acciones que van desde el contralor rutinario hasta las sanciones legales o el impeachment, en relación con actuaciones u omisiones de otras instituciones del estado que pueden en principio o presuntamente ser calificadas como ilícitas ${ }^{40}$ (O'DONNELL, 1993, p. 130)

Estas instâncias de controle garantiriam que os processos participativos promovidos pelo Estado não lhe isentassem da responsabilidade de assegurar condições de vida digna para a sua população, como estabelecido nas constituições republicanas e federais dos países latino-americanos. No entanto, a tendência é a de, cada vez com maior intensidade, transferir funções em troca apenas de recursos que geralmente também são insuficientes para fazer mudanças significativas.

Desta forma, o novo modelo implica um Estado regulador - financiador e um grupo de OSC implementadoras (com tendência a diversificar seus âmbitos de participação), vendo-se absolutamente influenciado o papel de cada um dos atores. Se bem a atuação das OSCs pode potenciar a ação do Estado e até o seu alcance,

\footnotetext{
${ }^{40}$ Tradução livre da pesquisadora - Existência de instituições estatais que têm autoridade legal e estão dispostas e capacitadas para empreender ações que vão desde o controle rotineiro até sanções penais ou, inclusive, impugnação em relação a atos ou omissões de outros agentes ou instituições do Estado que possam, em princípio, ou presumidamente, ser qualificados como ilícitos.
} 
há uma perda de identidade e autonomia das instituições da sociedade civil, mediada pela transferência de recursos públicos em troca de premissas claras de atuação.

Explica Midaglia:

En este marco las asociaciones civiles adquieren un nuevo status público, puesto que son reconocidas y valoradas en términos de encargarse de la provisión de bienes sociales, en particular los dirigidos a poblaciones pobres y excluidas que carecen de posibilidades de satisfacer sus necesidades vía el mercado. Para asumir estas funciones el Estado les traspasaría servicios y recursos financieros, posibilitando la consolidación del llamado Tercer Sector - Público No Estatal, constituido por diversos tipos de entidades sociales $^{41}$ (MIDAGLIA, 2000, p. 21).

Nesse sentido, apresenta-se o risco de que "la participación de esas organizaciones se transforme en un instrumento de recorte presupuestario, en una estrategia asistencial apenas paliativa que refuerza bajo otras circunstancias históricas los bloqueos a la integración social”42 (MIDAGLIA, 2000, p. 22).

Cabe advertir que, mesmo com os diversos atributos que as organizações do terceiro setor possam desenvolver e tenham dado conta no decorrer destes anos todos, o Estado continua sendo o único agente que possui condições para gerar um sistema de proteção social coeso e, portanto, o seu empenho por descentralizar suas funções deve ser visto e tratado com especial atenção.

\subsubsection{O papel da Comunidade local}

Além da constelação de agentes mencionada acima, ao se analisar a América Latina, exemplos não faltam para ilustrar a forma em que o poder centralizador declina em detrimento de um poder local que se afirma e se legitima nas sociedades contemporâneas. Há nas últimas décadas um deslocamento dos centros de decisão, observando-se uma multiplicação de atores e interlocutores, dentre os quais se realçam as comunidades, além da adoção de uma gama variada de dispositivos

\footnotetext{
${ }^{41}$ Tradução livre da pesquisadora - Neste marco as associações civis adquirem um novo status público, já que são reconhecidas e valorizadas em termos de se responsabilizar pela provisão de bens sociais, em particular, os dirigidos à população pobre e excluída que carece de possibilidades de satisfazer suas necessidades via mercado. Para assumir estas funções o Estado Ihes transpassaria serviços e recursos financeiros, possibilitando a consolidação do chamado terceiro setor ou público não estatal, constituído por diversos tipos de organizações sociais.

${ }^{42}$ Tradução livre da pesquisadora - A participação dessas organizações se transforme em um instrumento de recorte orçamentário, em uma estratégia assistencial apenas paliativa que reforça baixo outras circunstâncias históricas, o bloqueio à integração social.
} 
administrativos, legais e interinstitucionais (PEREIRA, 2007). Desta forma, aumentase a capacidade do governo através da corresponsabilidade individual.

Isto traz à tona o último elemento do tripé das políticas sociais neoliberais mencionado acima: a descentralização. Trata-se, assim, de transferir aos níveis locais ou territoriais as decisões em matéria de políticas sociais, sobre o entendido de que é na comunidade onde se encontra o problema e, portanto, é dela que tem que surgir a solução.

Melo (1997) coloca que a descentralização determina a transferência de poder a níveis intergovernamentais em três esferas: administrativa, financeira e programática.

\begin{abstract}
Entendida enquanto transferência de poder decisório a municípios ou entidades e órgãos locais, a descentralização expressa, por um lado, tendências democratizantes, participativas, e de responsabilização; e, por outro, processos de modernização gerencial da gestão pública [...]. Essas duas dimensões complementares estão presentes nos processos de descentralização, mas a importância relativa assumida por esses dois vetores depende da natureza da coalizão política que dá suporte às reformas (MELO, 1997, p. 269).
\end{abstract}

Esta perspectiva tem conquistado adeptos de todas as vertentes. Para os neoliberais, a descentralização é útil, pois beneficia o livre desenvolvimento do mercado e garante o investimento de menor quantidade de recursos. Para os que não concordam com as estratégias neoliberais, a ideia de descentralização atrai pelo tom que este novo fenômeno daria à democracia a possibilidade de participação que outorgariam as políticas descentralizadas. Neste sentido, segundo Melo (1997), existem dois tipos de justificativa para a implementação de políticas descentralizadas: uma de ordem política e outra de ordem econômica. Entre as primeiras, encontra-se o fato de promover a democracia participativa ao mesmo tempo em que se preservariam as identidades territoriais, principalmente em regiões que mantêm fortes clivagens étnicas e culturais. A respeito das segundas, o fator positivo refere à eficiência que se alcança em termos financeiros, já que as políticas se ajustam às necessidades das populações locais, tendo um maior controle sobre as transferências dos gastos públicos. Este fator vem ao encontro com o que já se abordou sobre os paradoxos da focalização.

Por outro lado, mesmo com considerações que fazem da descentralização um elemento "bem visto", ela contém efeitos que colocam sua legitimidade em 
questão. Com base nos trabalhos de Filgueiras (1998) e Iribarren (2008) podem-se identificar os seguintes efeitos conflitantes:

(1) Transferência de funções sem que as estruturas locais tenham suficiente capacidade institucional para responder a tais exigências. Frequentemente se produz uma multiplicação local na prestação de serviços podendo haver superposição de recursos nos territórios melhor articulados, assim como excessiva presença de políticas sem conexão entre elas.

(2) Clientelismo. Segundo Filgueira, este risco depende em grande medida do tipo de relações preexistentes entre moradores de uma comunidade e as autoridades locais. Assim, há uma tendência a beneficiar os grupos que estão mais próximos dos centros de poder, mesmo que locais.

La promesa de la participación que generaría modalidades de descentralización política (esto es en la toma de decisiones) puede verse burlada en los casos en que las autoridades locales han estado históricamente conformadas por elites locales(o son muy porosas a ellas) que establecían relaciones neopatrimoniales con los habitantes locales ${ }^{43}$ (FILGUEIRA, 1998, p. 98).

(3) Iniquidade de distribuição no âmbito regional. É possível que as regiões melhor entrosadas com os âmbitos políticos contenham as maiores fontes de recursos. Para que isto não ocorra, devem existir mecanismos de participação democrática transparentes e efetivos, que nem sempre são observados nas administrações de turno. A respeito, Filgueira expressa:

Si la descentralización se realiza en naciones fuertemente heterogéneas y estratificadas a escala local y regional, sin ninguna institución o actor que habilite la redistribución de poder político interregional y los efectivice en instituciones "accountables" locales, el resultado será muy posiblemente el de agudizar las inequidades distributivas $^{44}$ (FIGUEIRA, 1998, p. 101).

(4) “Neolocalismo". Segundo Iribarren (2008), este fenômeno acontece quando as autoridades locais procuram atrair investimentos, diminuindo as cargas fiscais que permitem financiar os gastos sociais, e se diminuem as prestações sociais dos setores pobres para evitar o assentamento destas populações no

\footnotetext{
${ }^{43}$ Tradução livre da pesquisadora - A promessa da participação que geraria modalidades de descentralização política (isto é na tomada de decisões) pode se ver burlada nos casos em que as autoridades locais são historicamente formadas por elites locais (ou são muito porosas a elas) que estabeleceram relações neopatrimoniais com os habitantes locais.

${ }^{44}$ Tradução livre da pesquisadora - Se a descentralização se realiza em nações fortemente heterogêneas e estratificadas a escala local e regional, sem nenhuma instituição ou ator que habilite a redistribuição de poder político interregional e os efetive em instituições "accountables" locais, o resultado será muito possivelmente o de agudizar as inequidades distributivas.
} 
território, favorecendo a segregação territorial. Como expressa Filgueira na seguinte passagem:

El efecto agregado del incremento de las desigualdades regionales y las políticas de incentivos locales al capital y desincentivos al asentamiento $o$ permanencia de poblaciones vulnerables incrementaría la distancia entre localidades, agudizaría pautas de segmentación social y favorecería formatos de "apartheid social ${ }^{45}$ (FILGUEIRA, 1998, p. 101).

Colocadas, mesmo que rapidamente, as principais caraterísticas deste processo de descentralização que invoca o protagonismo da comunidade, interessa destacar que nos últimos anos, há uma clara intenção de envolver os grupos comunitários no seu próprio desenvolvimento. Tanto governos, quanto organizações internacionais, corporações empresariais, organizações da sociedade civil, colocam especial ênfase em apoiar iniciativas de desenvolvimento local, que incluam participação ativa da população e, principalmente, protagonismo de líderes comunitários, tornando a participação um requisito excludente na hora de escolher as áreas onde se implementarão as políticas e o público que se beneficiará delas. No entanto, esta participação não deixa de ser relativa, pois, frequentemente, faz parte apenas das etapas de operacionalização e não necessariamente se dá nas de desenho e elaboração.

No dizer de Kliksberg:

El discurso latino-americano es cada vez más unánime respecto a la participación. Tiene un "centimetraje" altísimo en las exposiciones públicas de líderes de todo orden de organizaciones públicas y privadas. Sin embargo, los avances en los hechos son limitados. Los indicadores muestran escasos progresos en cuanto al establecimiento de políticas concretas de participación, el apoyo sustantivo a las experiencias participativas en marcha, la búsqueda de nuevos instrumentos jurídicos, institucionales y financieros para apoyarla. ¿Qué está sucediendo en la realidad?. Pareciera que, por un lado, es tan fuerte la demanda pública por participación que resulta casi no viable darle la espalda. Por otro, como suele suceder las resistencias profundas que hay a la misma se refugian en el nivel de la gestión, que es aquel que da forma a las políticas reales. Allí la participación tiende a ser bloqueada ${ }^{46}(2002$, p. 35).

\footnotetext{
${ }^{45}$ Tradução livre da pesquisadora - O efeito agregado do incremento das desigualdades regionais e as políticas de incentivos locais ao capital e desincentivos ao assentamento ou permanência de populações vulneráveis incrementaria a distância entre localidades, agudizaria pautas de segmentação social e favoreceria formatos de "apartheid social".

${ }^{46}$ Tradução livre da pesquisadora - O discurso latino-americano é cada vez mais unânime com respeito à participação. Tem uma "centimetragem" altíssima nas exposições públicas de líderes de toda ordem de organizações públicas e privadas. No entanto, os avanços nos fatos são limitados. Os indicadores mostram escassos progressos quanto ao estabelecimento de políticas concretas de participação, o apoio substantivo às experiências participativas em marcha, a procura de novos instrumentos jurídicos, institucionais e financeiros para apoiá-las. O que está acontecendo na realidade? Pareceria que, por um lado, é tão forte a demanda pública
} 
Assim, o papel da comunidade local torna-se um recurso consignado. Se por um lado a sua participação é interessante porque se supõe que as necessidades seriam melhor identificadas e, por tanto, haveria políticas mais efetivas; por outro, a responsabilidade pelo sucesso ou fracasso de programas sociais deixa de ser assunto de Estado para ser estritamente responsabilidade da comunidade local. Frente ao discurso da promoção da democracia, se legitima o discurso da privatização, focalização, descentralização e terceirização. Novamente o Estado encontra formas de governar que the exime de compromissos e o distancia dos efeitos da pressão social.

\section{A INTERVENÇÃO DO ESTADO E O NOVO ENFOQUE DAS POLÍTICAS PÚBLICAS NO BRASIL}

O Brasil foi o último dos países da América Latina a abrir as portas para as políticas neoliberais, e elas surgiram em um momento em que se passava por um processo inflacionário devastador, que apresentava um saldo de miséria e concentração de renda inéditos no país. As primeiras reformas aconteceram com o governo Collor de Melo, o qual iniciou um período de desregulamentação econômica, com tentativas de abertura do mercado e estratégias que buscavam conter a inflação, principalmente ao que se relaciona com o Fundo Monetário Internacional. O resultado foi o bloqueio da poupança da população e a corrupção, fatos que contribuíram para a substituição do presidente pelo seu vice, Itamar Franco.

Dessa forma, o projeto neoliberal implanta-se no Brasil com um discurso liberal radical, que combinando a abertura da economia e o processo de privatizações, inaugura a 'era liberal' no país (FILGUEIRAS, 2006).

O modelo de substituição de importações vê assim o início de seu fim, enquanto assiste atento ao incerto que ocupará seu lugar. Iniciaram-se processos generalizados de reestruturação produtiva dentro das empresas. Houve fechamento de fábricas, enxugamento de plantas, redução de hierarquias, concentração da produção nas áreas ou produtos de maior retorno, terceirização, modernização 
tecnológica e redefinição organizacional dos processos produtivos e demissão em massa dos operários que davam vida às indústrias brasileiras. Em todos os casos os esforços se concentrariam primordialmente na racionalização de custos, principalmente os referentes ao trabalho (COSTA, 2005; MORAIS E SAAD-FILHO, 2005).

Pode-se afirmar que se tratava, principalmente, de um período de recessão no qual primava somente a proteção da inflação e da moeda por meio da elevação da taxa de juros e a flexibilização institucional do mercado de trabalho. As políticas públicas iniciadas nos períodos anteriores foram abandonadas e no seu lugar colocaram-se programas parciais de atenção às necessidades básicas. Muitos dos trabalhadores não encontraram mais lugar na fábrica e tiveram que migrar para o setor dos serviços que não exigia alta qualificação e admitia salários baixos, ou engrossaram as filas da informalidade (MEDEIROS, 1994; COSTA, 2005).

Estas primeiras medidas serão aprofundadas pelos governos seguintes, onde continua caindo o ritmo do desenvolvimento econômico, abandonam-se os ideais de crescimento industrial, que tardiamente haviam entrado no país, e muda significativamente o papel do Estado, visto já não mais como empresário e provedor de serviços.

No governo de Itamar Franco, e especialmente a partir do ano 1992, com a assunção de Fernando Henrique Cardoso no Ministério de Relações Exteriores, retomam-se os vínculos iniciados por Collor com o Banco Mundial e o FMI e mais tarde, com a sua assunção no Ministério da Fazenda e a elaboração do Plano Real, começa um período de reforma estatal que nada mais é do que a configuração de um sistema de políticas neoliberais, que se acentuam ainda mais quando o ministro assume a presidência da república. Este modelo servirá de base para os dois períodos da presidência de FHC e também, contrário ao que muitos imaginavam, para os dois períodos em que Lula ocupou a presidência.

Em 1997, Bresser Pereira anunciava:

Nossa previsão é a que o Estado do Século XXI será um Estado Social Liberal: social porque continuará a proteger os direitos sociais e a promover o desenvolvimento econômico; liberal porque o fará usando mais os controles de mercado e menos os controles administrativos, porque realizará seus serviços sociais e científicos principalmente através de organizações públicas não estatais competitivas, porque tornará os mercados de trabalho mais flexíveis, porque promoverá a capacitação dos seus recursos humanos e de 
suas empresas para a inovação e a competição internacional (BRESSER PEREIRA, 1997, p. 60).

Parte da profecia de Bresser Pereira efetivamente foi cumprida, porém no que refere à proteção dos direitos sociais, o prognóstico não condiz com a realidade. Nos primeiros anos da década de 1990, os direitos sociais e trabalhistas sofrem um processo de redução ainda maior do que aquele que sofreram durante a fase ditatorial-militar (BOITO JR, 2007). Houve reforma administrativa, reforma da previdência, privatizações e redefinição do papel do Estado na economia, causando recessão econômica, ingresso do capital externo, flexibilização dos direitos do trabalho, aumento da dívida externa e interna, desmonte dos sistemas de seguridade social, de saúde e de educação, aumento do trabalho informal e desemprego.

Com a reeleição de Fernando Henrique Cardoso, veio um novo pacote de medidas trabalhistas, que anularam em grande parte, as conquistas obtidas pelos operários organizados em sindicatos, principalmente no que diz respeito à estabilidade e à jornada de trabalho preestabelecida.

As novas medidas legislativas alteravam as regras trabalhistas básicas, como o vínculo contratual, a jornada e o salário, "vulgarizando o conceito de rigidez do direito e do mercado de trabalho e banalizando a negociação coletiva e o papel do estado" (SIQUEIRA NETO, 1996, p. 328).

Segundo Costa (2005),

O contrato de trabalho por tempo determinado, o trabalho em tempo parcial, a suspensão temporária do contrato de trabalho por motivos econômicos, o banco de horas, a participação nos lucros e resultados das empresas, a redução do salário com redução da jornada, entre outros, passaram a fazer parte do rol de possibilidades legais de mudança nos contratos de trabalho. Em seu conjunto, essas medidas representaram um verdadeiro desmonte dos direitos de proteção ao trabalho e um retrocesso no espaço recentemente conquistado pelo movimento sindical (COSTA, 2005, p. 121).

Frente a esta série de acontecimentos, o movimento sindical encontrava-se debilitado, não só pela sua captação no período Vargas e pela perda de forças derivada da limitação de sua intervenção no período ditatorial, senão também pela redução da quantidade e da importância dos operários na fábrica. Os trabalhadores não possuíam na década de 1990 um fator altamente aglutinador que lhes permitisse se organizar novamente de forma coesa e forte o suficiente para enfrentar a deslegitimação de suas ações. Foi assim que o neoliberalismo também se 
imbricou nos sindicatos, que se tornaram os novos aliados do capital, abandonando seu papel reivindicativo e de adversários. Passaram a atuar na cooperação e na parceria com o capital, característica que identificou também os oito anos do governo do presidente Lula, período no qual houve uma grande despolitização dos sindicatos. Ao dizer de Nogueira, "Os movimentos sociais voltaram-se mais para a gestão da política do que para a oposição a ela" (NOGUEIRA, 2004, p. 58), estabelecendo-se uma relação estreita entre governo, partido e sindicato, o que segundo Marques e Mendes:

Explica, em parte, porque foi tão fácil para o governo aprovar a reforma da previdência, não valorizar o salário mínimo e promover o aumento do desemprego em seu primeiro ano. As massas, mesmo descontentes, não tinham como se expressar: suas formas tradicionais de organização estavam, pela mão de suas direções, a serviço do governo. Somente os funcionários públicos, tendo em vista o significado da reforma encaminhada por Lula, tiveram força para se fazerem ouvir, mas mesmo assim ficaram isolados e foram derrotados (MARQUES E MENDES, 2006, p. 64).

Em 2003, Lula assume a presidência de um país endividado, o que lhe dava uma margem de manobra estreita e, talvez isso explique, pelo menos parcialmente, a continuidade de muitas das medidas econômicas do período anterior tais como ajuste fiscal, altas taxas de juros, acordos com o FMI, entre outras.

Nesse sentido, elementos tais como a desregulamentação e a "mercadorização" que reduziu os gastos sociais tradicionais do Estado, atendendo à pressão do grande capital para apropriar-se do orçamento público, foram mantidas pelo novo governo, preservando as reformas promovidas por $\mathrm{FHC}$, além de ter realizado outras que incluíam privatizações e novas flexibilizações. Essa nova conjuntura traz aquela que era uma característica do modelo capitalista vigente no período anterior a 1930: o mercado de trabalho desregulamentado e a ausência de direitos sociais (BOITO JR, 2007).

Desta forma, contrário ao que muitos esperavam, o governo Lula foi, principalmente, de concessão. Concessões estas que buscaram evitar o conflito e caminhar para um progressismo econômico que, sem descuidar dos interesses do capital, olhasse também para a classe trabalhadora, operária ou não. Foi um governo que utilizou as mais diversas armas de sedução através das quais conquistou aliados em todas as classes sociais. Utilizou uma postura conciliadora e não confrontacionista, que lhe permitiu avançar nos seus projetos sem ser 
amplamente questionado nos seus afazeres, pelo contrário, ganhou índices de popularidade nunca antes vistos na história do país.

A política social assumida pelo governo foi uma das grandes responsáveis por isso, mesmo que reproduzindo as teses defendidas pelo Banco Mundial nas últimas duas décadas, priorizando a focalização, a descentralização e a terceirização de serviços públicos, em consonância com a realidade latino-americana abordada acima. Tratou-se de estabelecer um sistema de política pública que redirecionava os recursos disponíveis, por meio de duas principais estratégias: redução de gastos com aposentadorias e pensões, e implementação de programas de renda mínima condicionada, dirigidos aos mais pobres. São políticas compensatórias, claramente exemplificadas com o programa Fome Zero que, posteriormente, foi aprimorado com a inauguração em 2004 do Ministério do Desenvolvimento Social e do Combate à Fome e a criação do programa "Bolsa Família", fruto da unificação de diversos programas pré-existentes, tais como o "Bolsa Escola", "Bolsa Alimentação", "Cartão Alimentação" e o “Auxílio Gás” (NAYME NOVELLI, 2010).

Desta maneira, pode-se observar que:

Em nome da estabilidade, do crescimento e do cumprimento dos "contratos" com os credores internacionais e nacionais, abandona-se a ideia de universalização das políticas sociais, adotando as antigas formas assistencialistas para os pobres e deixando para os demais (embora não-ricos), como única alternativa, o mercado (MARQUES E MENDES, 2006, p. 73).

A partir do exposto, nota-se que as políticas sociais, isto é, a intervenção do Estado na vida pública de sua população, não é mais atribulada à condição de trabalhador e sim à condição de pobre. Isto é evidente quando se constata que se fala de um mercado que não comporta a série de trabalhadores que ele mesmo expulsou em razão das novas medidas adotadas pelos Estados. Estudos realizados por Cacciamali mostram que, em 1991, a participação dos empregados formais na economia era de 53\%, e em 2000 ela cai para 45\%. No mesmo sentido, o grau de informalidade que era de $36,6 \%$ em 1986, aumentou para $37,6 \%$, em apenas 4 anos, passando para 50,8\% no ano de 2000 (CACCIAMALI, 2000).

Desta maneira, pode-se observar que o principal aspecto do neoliberalismo que afeta negativamente as classes trabalhadoras é a desregulamentação do mercado de trabalho e com isto, a supressão e redução dos direitos sociais.

De acordo com Filgueiras: 
Junto com o desemprego e como produto de uma ampla desregulação do mercado de trabalho - efetivada na prática pelas empresas e por diversos instrumentos jurídicos emanados dos sucessivos governos - veio um processo generalizado de precarização das condições de trabalho - formas de contratação instáveis que contornam ou burlam a legislação trabalhista, prolongamento da jornada de trabalho, redução de rendimentos e demais benefícios, flexibilização de direitos trabalhistas e ampliação da informalidade (FILGUEIRAS, 2006, p. 188).

Assim como o Estado criou estratégias para subsidiar as necessidades básicas por meio de programas de renda condicionada, mencionados anteriormente, também teve que criar estratégias que equilibrassem a crise da situação laboral que emergia. Para isto, retomou as bases existentes no Sistema Nacional de Emprego (SINE), criado em 1975 e construiu novos programas tais como o Programa de Geração de Emprego e Renda (PROGER), o Programa Nacional de Microcrédito Produtivo Orientado (PNMPO) e outros que buscavam amortizar os efeitos negativos do novo sistema. São estes bons exemplos de políticas focalizadas, com escassa articulação entre elas, que refletem o comportamento de um Estado mínimo, que busca conter a pobreza e a desigualdade por meio da atuação compartilhada entre diversos atores, fundamentalmente, a própria classe trabalhadora.

Com base nestes exemplos, é possível observar como a constelação de agentes mencionada para o caso da América Latina encontra eco também no caso brasileiro. É a somatória de ações de diversos agentes que permite o desenvolvimento e a permanência deste tipo de medidas adotadas pelos Estados modernos.

No caso dos organismos internacionais, as medidas adotadas por Estados modernos tiveram grande importância no desenvolvimento das novas políticas sociais, direcionando os campos de ação em troca de recursos e assistência técnica.

As corporações empresariais, por sua vez, assumem a cara da "filantropia empresarial", motivada pela percepção da agudização da pobreza e da desigualdade social e a necessidade e/ou conveniência de intervir para modificar, ou pelo menos atenuar, esta realidade. Não obstante, estas estratégias que nascem no setor privado não buscam estabelecer qualquer debate público acerca das causas que levam a esta desigualdade. Defende ações eficientes e privadas para minorar tal situação sem, entretanto, debater estratégias mais estruturantes e de longo prazo para extinguir suas causas (FERES FARIA, 2010). As estratégias inserem-se 
"menos em uma lógica da cidadania e mais na eficiência da integração social para limitar o perigo e o risco inerente à presença aumentada dos excluídos e semdireitos" (PAOLI, 2002, p. 414).

Referente ao papel das organizações da sociedade civil, estas contribuíram "para dar prosseguimento ao processo de descentralização política e à formação de instâncias colegiadas cuja função é auxiliar na formulação, no controle e na execução das políticas setoriais" (FERES FARIA, 2010, p. 191). Neste sentido, as OSCs se tornaram os novos agentes executores das políticas sociais, em um cenário onde o Estado transfere as responsabilidades públicas para as comunidades, famílias e indivíduos organizados pelas OSCs. Desta forma, as organizações sociais passam a ser apenas prestadoras de serviços do Estado, sem participação real na elaboração dos programas e projetos (TEIXEIRA, 2002; PINTO, 2004; FARIA, 2010).

Esta aproximação da sociedade civil com as comunidades locais onde ocorrem as políticas sociais focalizadas visa o que alguns autores entendem por desenvolvimento local, buscando melhorar as condições de vida da população que ali mora por meio de intervenções em regiões específicas, em troca de participação e corresponsabilidade. Aplicam-se programas e projetos que buscam fomentar o desenvolvimento de sujeitos individuais e coletivos, capazes de cuidar de sua própria vida e de sua comunidade de referência. Trata-se de criar estratégias de produção e reprodução da força de trabalho ligadas a novas formas de geração de trabalho e renda, em um contexto de mercado de trabalho cada vez mais fragmentado, e uma classe trabalhadora, cada vez mais flexível.

\section{A INTERVENÇÃO DO ESTADO E O NOVO ENFOQUE DAS POLÍTICAS PÚBLICAS NO EQUADOR}

A década de 90 também representou mudanças significativas na administração da questão social no Equador decorrentes das recessões econômicas que se iniciavam no cenário mundial. Apenas as áreas referentes à saúde com programas de prevenção e de educação básica permaneceram com pretensão de universalidade, tentando coexistir com as exigências de modernização.

Acompanhando a tendência do resto dos países da América Latina, o Equador promoveu a realização de programas focalizados e regionais, além de 
descentralizar suas funções para o setor das OSC. Por outro lado, os organismos de cooperação internacionais e de desenvolvimento, intervêm diretamente nas instâncias de elaboração e execução das políticas sociais (BUSTELO, 2003; VÁSCONEZ, 2003).

Estes produzem e impõem receitas unificadas para que os governos centrem sua ação social no combate à pobreza, concebendo-a como um fenômeno transitório que se pode prevenir com medidas de curto prazo, onde seria fundamental a focalização e a gestão compartilhada. Fazendo referência a esta incumbência dos organismos internacionais Stahl coloca:

Siguen apegados a su pensamiento neoliberal, el cual presupone que las fuerzas libres del mercado conjuntamente con un crecimiento económico continuo darán lugar casi automáticamente al bienestar social, es decir, que con un ajuste estructural exitoso los que fueron socialmente excluidos volverán a integrarse al circuito económico ${ }^{47}$ (STAHL, 1994, p. 50).

Os novos programas nascem reafirmando a concepção colocada anteriormente e se desenvolvem tendo como carro-chefe a focalização, que toma maior relevância a partir de 1996, no governo de Bucaram, o qual "marca la pauta de utilizar la focalización y la atención asistencial para el sostenimiento frente al ajuste, política que se mantendrá y profundizará en sucesivos gobiernos"48 (VÁSCONEZ, 2003, p. 44).

A segunda parte da década de 1990 representou um período no qual os presidentes que passaram pelo governo se preocuparam por oferecer um pacote de prestações que continha moradia, alimentação e material escolar, limitando a intervenção do Estado ao atendimento da emergência, porém com um discurso de acolher aos mais necessitados, fato que acabou por institucionalizar a pobreza.

De acordo com as novas diretrizes vindas dos organismos internacionais, cria-se no ano de 1998 o Programa de Transferência de Renda Bono Solidário, que consiste em um subsídio monetário destinado à população de baixa renda (LEÓN, 2003; ARMAS, 2004). Segundo Stahl,

\footnotetext{
${ }^{47}$ Tradução livre da pesquisadora - Continuam ligados ao seu pensamento neoliberal, o qual pressupõe que as forças livres do mercado conjuntamente com o crescimento econômico contínuo darão lugar quase de forma automática ao bem estar social, ou seja, que com o ajuste estrutural exitoso os que foram socialmente excluídos se reintegrarão no circuito econômico.

${ }^{48}$ Tradução livre da pesquisadora - Marca a pauta de utilizar a focalização e a atenção assistencial para a sustentabilidade frente ao ajuste, política que se manterá e aprofundará nos sucessivos governos.
} 
El principio del subsidiarismo corrobora por una parte la responsabilidad social del Estado frente a los miembros de la sociedad, y el derecho del individuo a la protección social a través de instancias superiores, cuando él no puede asegurar más su existencia a partir de su propia iniciativa ${ }^{49}$ (STAHL ,1994, p. 63).

Em 2003, no governo de Gutierrez, este programa se transforma em Bono de Desarrollo Humano e passa a ser um Programa de Transferência de Renda Condicionada, que inclui a corresponsabilidade, condicionando o beneficio ao uso de serviços de educação e saúde, pois há quem defenda que uma das razões fundamentais da reprodução da pobreza é a falta de investimento em capital humano (VILLATORO, 2005), principalmente no que diz respeito às duas áreas mencionadas. Nesse sentido, garantir o acesso à saúde e à educação seria uma via efetiva para minimizar os efeitos da pobreza. No entanto, estudos sobre estes programas são mais cautelosos quando analisam o real efeito desses tipos de programas.

É o caso de Vásconez quando disserta sobre estes tipos de programas, afirmando que contribuem para debilitar o já reduzido enfoque de cidadania como princípio de políticas, sem atingir soluções estruturais nem para a pobreza, nem para a desigualdade (VÁSCONEZ, 2003). São programas que expressam antes de tudo a ação de um Estado coercitivo e mínimo, que se apoia na execução de programas privados, terceirizados e de duvidoso impacto. Kingman reforça essa ideia ao anunciar que:

Estas compensaciones no responden a una búsqueda de desarrollo social, tampoco conducen a solucionar la pobreza. Al igual que la institución clerical de la Caridad, este tipo de acciones, propio de las políticas de ajuste, convive con la pobreza, no la elimina ${ }^{50}$ (KINGMAN, 2002, p. 8).

O campo laboral também foi amplamente afetado com a nova conjuntura econômica e com as medidas que foram adotadas pelos governos. Continuou-se um processo acelerado de flexibilização e se desmantelou o marco regulatório laboral. Exemplos disso foram: as limitações aos contratos coletivos, as reformas do Código do Trabalho, o surgimento da contratação por horas, a terceirização de serviços,

\footnotetext{
49 Tradução livre da pesquisadora - O princípio do subsidiarismo corrobora por um lado com a responsabilidade social do Estado perante os membros da sociedade e o direito do indivíduo à proteção social através de instâncias superiores, quando ele não pode assegurar mais sua existência a partir de sua própria iniciativa.

${ }_{50}$ Tradução livre da pesquisadora - Essas compensações não respondem a uma pesquisa para o desenvolvimento social, nem levam para a solução da pobreza. Como a instituição clerical da Caridade, este tipo de ação, próprio das políticas de ajuste, coexiste com a pobreza, não a elimina.
} 
entre outras medidas que decorriam da aceitação dos conteúdos dos tratados de livre comércio e os contratos com corporações internacionais, sendo que em 1999 o desemprego alcançou sua máxima expressão.

Os movimentos indígenas e de operários apresentavam suas demandas, porém os grupos organizados, leia-se sindicatos, não representavam uma possibilidade real de luta, cooptados, como no caso brasileiro, pelo poderes gremiais, corporativos e partidários.

\section{Segundo Vásconez,}

Estos procesos, así como la consecuente informalización de la economía, han desmantelado el movimiento sindical en Ecuador. Una mano de obra desprotegida y débil, ante la amenaza permanente de desempleo y una baja elasticidad frente al salario, permite que se fortalezca un modelo en el cual el salario ya no es más el referente ni del mercado ni de la productividad, sino únicamente del poder. La lucha sindical se da en el ámbito de las instituciones públicas y constituye un contrapeso para toda intención de reforma institucional y un elemento cíclico del proceso presupuestario, más que un agente de cambio ${ }^{51}$ (VÁSCONEZ, 2003, p. 46).

Em 2007, com a posse do atual Presidente, Rafael Correa, foram anunciadas novas determinações para a política social. Entre elas, o impulso ao plano de geração de emprego com créditos e apoio integral, a redução da brecha salarial ao reduzir os gastos que comprometem a renda familiar e a criação da Subsecretaria da Economia Social e Solidária sob a alçada do Ministério de Economia e Finanças.

Nesse sentido, o principal programa de transferência de renda, o Bono de Desarrollo Humano, incluiu algumas modificações, entre os quais se destaca o fato dos beneficiários serem priorizados em programas de micro-finanças, como forma de inclusão produtiva. Ao respeito, a Ministra de Bienestar Social, Janeth Sánchez, expressa que se trata de um avanço na forma de fazer política social. Segundo ela, "Es el hecho de salir del asistencialismo que ha conducido a las relaciones clientelares hacia el desarrollo social, a una política que promueva este desarrollo y construya ciudadanía" ${ }^{2}$ (HERNÁNDEZ, 2007).

\footnotetext{
${ }^{51}$ Tradução livre da pesquisadora - Estes processos, assim como a consequente informalização da economia, desmantelaram o movimento sindical no Equador. Uma mão de obra desprotegida e fraca, frente à ameaça permanente de desemprego e uma baixa elasticidade frente ao salario, permite que se fortaleça um modelo no qual o salário já não é mais referência nem no mercado nem da produtividade, senão unicamente do poder. A luta sindical se dá no âmbito das instituições públicas e constitui um contrapeso para toda intenção de reforma institucional e um elemento cíclico do processo orçamentário, mais do que um agente de câmbio.

${ }^{52}$ Tradução livre da pesquisadora - É o fato de sair do assistencialismo que conduziu as relações clientelistas para o desenvolvimento social, a uma política que promova este desenvolvimento e construa cidadania.
} 
A inclusão econômica da qual se fala contempla assistência técnica, acesso a créditos e trabalho, por meio do desenvolvimento de projetos produtivos inclusivos com potencial de mercado, porém que contenham a responsabilidade social e ambiental. O Estado se compromete a adquirir a produção local, garantindo a comercialização, através do sistema de compras públicas.

Pode se observar que a questão da geração de trabalho e renda entra nas agendas públicas, principalmente no decorrer do século $\mathrm{XXI}$, no caso do Equador, acoplada a programas focalizados de transferência de renda, visando ampliar seu alcance e resultados; e no caso do Brasil, em paralelo a estes, porém com claras intenções de se converter no novo guarda-chuva da questão social. Uma discussão mais detalhada sobre este assunto será realizada no próximo capítulo.

Assim, de acordo com Clevaer, "Ou o capital encontra novas maneira de impor o trabalho, e, portanto, de realizar o valor, ou a luta da classe operária contra o trabalho faz explodir o sistema e cria outro, novo" (CLEAVER, 1981, p. 101).

É sobre essas bases que se discute a seguir, como também sobre o papel da economia solidária, analisando se esta pode ou não ser entendida como uma dessas formas que o capital assume para garantir a produção e a reprodução da força de trabalho, seguindo a lógica de cooptação e repressão que o Estado vem desenvolvendo desde que se constituiu no principal coadjuvante do capitalismo. 


\section{CAPITULO III}

\section{AMÉRICA LATINA ECONOMICAMENTE SOLIDÁRIA: NOVAS FORMAS DE PRODUÇÃO E REPRODUÇÃO DA FORÇA DE TRABALHO?}

\section{ECONOMIA SOLIDÁRIA: PARA UMA GENEALOGIA DO CONCEITO}

Observou-se nos capítulos anteriores que a proteção social como política pública esteve sempre vinculada à relação com o trabalho assalariado. Porém, o que acontece quando o desemprego, a flexibilização, a expansão do trabalho parcial, temporário e itinerante assume uma expressão do tamanho que alcançou nos países da América Latina? Arriscando uma resposta, pode-se dizer que novas formas de produção e reprodução da força de trabalho tiveram de ser concebidas.

Sobre estes pilares são analisadas, neste capítulo, as políticas públicas relacionadas à economia solidária. Tem a economia solidária um potencial de transformação capaz de modificar as tradicionais formas de produção social ou se trata apenas de mais uma estratégia para minimizar os efeitos de um sistema excludente, de forma a garantir a produção e a reprodução da força de trabalho?

Frente às grandes e significativas mudanças que ocorreram no mundo do trabalho nas últimas décadas, quando o trabalho assalariado perde centralidade e o chamado trabalho "alternativo" e "informal" deixa de ser a exceção, a economia relacionada ao social e ao solidário ganha se não centralidade, pelo menos visibilidade.

As experiências de organização do trabalho sob princípios de solidariedade e intercâmbio não são fenômenos novos na história, porém, nas últimas décadas há um iminente interesse que as coloca novamente em questão. Assim, além de recriar práticas tradicionais, também emergem formas inovadoras de solidariedade, genericamente denominadas economia solidária.

A literatura oferece diversas formas de se referir à questão, utilizando termos tais como economia solidária, economia social, economia sócio-solidária, economia da solidariedade, economia comunitária, economia popular, economia do trabalho, economia alternativa, economia plural, entre outros. No presente trabalho se utiliza o 
termo economia solidária para facilitar a compreensão, porém assumindo os matizes que ela possui e os riscos que a escolha representa.

Segundo Eid, a origem da economia solidária em oposição à economia liberal pode-se encontrar no fim do século XVIII, na Inglaterra, e no início do século XIX, na França (EID, 2003). Assim, se impulsiona o cooperativismo na Europa como estratégia para fazer frente aos efeitos da segunda Revolução Industrial, como foi explanado no primeiro capítulo deste trabalho. Tratava-se de tentativas isoladas, precárias e focalizadas, incitadas pelos trabalhadores para recuperar o trabalho e a autonomia econômica guiados pelos valores básicos do socialismo: democracia e igualdade (SANTOS, 2002).

$\mathrm{Na}$ América Latina, as práticas nesta direção encontram suas primeiras manifestações no Chile, com as organizações econômicas populares (OEP) que, de acordo com Quijano (1998), evoluíram como forma de resistência ao governo ditatorial de Pinochet, e com as empresas de autogestão iniciadas no governo Frei, e impulsadas por Allende, porém estas não permaneceram. No Peru, também podem ser encontrados antecedentes quanto à existência de uma tradição de comunidade e de reciprocidade mais prolongada e mais viva, conformando uma rede pelo país, com associações de vendedores ambulantes, microempresas autogestionárias, constituídas por trabalhadores demitidos, etc. (PATEO E FORTETE, 2011).

No entanto, com o avanço do capitalismo, estas práticas ficaram marginalizadas, e vem a adquirir força novamente no fim do século $X X$, dentro do novo contexto da globalização neoliberal, quando o sistema capitalista deixa à mostra sua incapacidade de garantir a inclusão de uma ampla quantidade de população no mercado de trabalho formal. Este cenário coloca a necessidade de criar novas estratégias de produção e reprodução da força de trabalho, já que uma grande parte dela está desassistida, desempregada e precarizada.

Segundo Gaiger, a economia solidária pode ser vista:

Seja como um campo de trabalho institucional, seja um alvo de políticas públicas de contenção da pobreza, seja ainda uma nova frente de lutas de caráter estratégico, visões, conceitos e práticas cruzam-se intensamente, interpelando-se e buscando promover a economia solidária como uma resposta para os excluídos, como base de um modelo de desenvolvimento comprometido com os trabalhadores, como saída diante do aprofundamento das iniquidades, das políticas neoliberais, do próprio capitalismo (2003, p. 183-184). 
Com relação ao exposto por Gaiger, desde a metade da década de 1990, a economia solidária tem sido objeto de estudo, tanto no oriente quanto no ocidente, ganhando adeptos e também críticos das mais variadas vertentes teóricas, fazendo com que hoje esteja sujeita a múltiplas possibilidades de compreensão.

França Filho considera que há pelo menos cinco caminhos que parecem possíveis para abordar a questão: enquanto discussão conceitual, enquanto discussão contextual, como estudo de caso, enquanto metodologia de intervenção e enquanto política pública (FRANÇA FILHO, 2007).

Dados os limites deste trabalho, buscar-se-á em primeiro lugar fazer uma aproximação conceitual sobre o assunto para submergir logo na mais recente modalidade de tratamento da questão: a sua dimensão como política pública.

Buscando fazer a genealogia do conceito, mesmo que resumida, se escolhe a visão de três autores que dão conta das principais diferenças na forma de olhar esta questão.

Entre os autores que defendem a economia solidária de forma aguerrida, escolhe-se a visão de Paul Singer, atual Secretário de Economia Solidária do Brasil, e estudioso do assunto. Desde outra perspectiva, mais crítica, porém ainda crente nos aspectos positivos que a economia solidária oferece como nova forma de produção, menciona-se o pensamento de Luiz Inácio Gaiger. Finalmente, retratando um olhar mais cético do conceito e suas manifestações, expõe-se resumidamente o pensamento do pesquisador peruano Aníbal Quijano.

Segundo Paul Singer, a economia solidária se desenvolve em diversos países desde o século XVIII, incitada por trabalhadores na prática e por pensadores socialistas, na teoria, com resultados que ele sintetiza da seguinte forma:

1) homens e mulheres vitimados pelo capital organizam-se como produtores associados tendo em vista não só ganhar a vida, mas reintegrar-se à divisão do trabalho em condições de competir com as empresas capitalistas; 2) pequenos produtores de mercadorias, do campo e da cidade, se associam para comprar e vender em conjunto, visando economias de escala e passam eventualmente a criar empresas de produção socializada, de propriedade deles; 3) assalariados se associam para adquirir em conjunto bens e serviços de consumo, visando ganhos de escala e melhor qualidade de vida; 4) pequenos produtores e assalariados se associam para reunir suas poupanças em fundos rotativos que lhes permitem obter empréstimos a juros baixos e eventualmente financiar empreendimentos solidários; 5) os mesmos criam também associações mútuas de seguros, cooperativas de habitação, etc. (SINGER, 2000, p. 14). 
A partir da leitura de diversos textos do autor, pode-se observar que a economia solidária é por ele relacionada diretamente com a existência de cooperativas de produção, prestação de serviços, comercialização ou crédito, que teriam um papel fundamental na luta pela igualdade e pelos direitos dos trabalhadores. No entanto, a referência do autor tem raízes em uma vertente reformista do socialismo do século XIX, visto também em Owen, questão mais aprofundada no primeiro capítulo desta dissertação. Trata-se de um socialismo muito presente na chamada Ala Centrista do Partido Social-Democrata Alemão, da Segunda Internacional, representada por Kautsky e Bernstein, e à qual Rosa Luxemburgo e Karl Liebknecht criticaram duramente, até que, em 1914, ocorre a grande cisão do partido.

A orientação centrista defendia como um caminho para o socialismo a luta parlamentar e as reformas promovidas pelo Estado em benefício da classe trabalhadora, sendo nesta perspectiva, um agente central no processo de mudança. Neste sentido, ao considerar a autogestão o pilar fundamental da economia solidária - como deixa entrever nos seus textos - a organização da produção passaria pelos próprios trabalhadores, deixando a eles a capacidade de transformação quando a história vem demonstrando que, enquanto as relações de poder não forem modificadas, os efeitos também não o serão.

No entanto, na visão de Singer, a economia solidária e a autogestão podem conviver com o sistema capitalista imperante, procurando formas mais equitativas e inclusivas de desenvolvimento. Neste sentido, destaca a importância da vinculação entre diversos agentes: OSC, movimentos religiosos, incubadoras universitárias, sindicatos e movimentos sociais que atuam no setor rural e urbano, apoiando iniciativas associativas comunitárias. Fazendo referência ao Brasil, mesmo a questão podendo ser generalizada para o resto da América Latina, segundo Singer, a economia estaria experimentando uma sinergia que combina "uma certa presença do Estado, uma presença da economia socialista ou solidária forte, uma presença de produção simples de mercadoria e, quem sabe, até, uma presença grande de economia doméstica" (SINGER, 2000a, p. 165).

O autor se baseia em experiências que, segundo ele, "deram certo", e conseguiram viabilizar-se mesmo dentro do sistema capitalista. Refere-se não só às práticas iniciadas por Owen, senão também aos Pioneiros de Rochdale, e experiências como a de Mondragón na Espanha, os Kibbutzim em Israel, o Affaire 
Lip na França, o movimento de ocupação de empresas, as fábricas recuperadas, entre outras (FARIA, 2005).

Nesse sentido, Singer acredita nos potenciais da economia solidária e entende que se trata de "uma revolução social em potencial, cuja culminação ou 'vitória' é uma possibilidade futura" (SINGER, 1998, p. 12). O autor se baseia, para fazer esta defesa, na história das lutas operárias e suas conquistas, fazendo referência à criação de instituições que contradisseram a lógica intrínseca do capitalismo, tais como os sindicatos e ao movimento cooperativista, e as conquistas referentes ao sufrágio universal, as leis trabalhistas, e a seguridade social, entre outras (Ibidem).

A discordância com Singer inicia-se exatamente neste ponto, por entender que, se assim considerada, a economia solidária apenas fará implantes na economia capitalista, de forma a "aliviar" os efeitos negativos do sistema, porém sem chegar a se constituir em uma forma hegemônica e permanente de organização da sociedade.

Além disto, nas publicações de Singer, a autogestão é entendida como uma forma de organizar a produção. No entanto, dentro da perspectiva que assume esta pesquisa, entende-se que a autogestão é um ponto de partida e não um ponto de chegada e, por isso, não pode ser confundida como mais uma técnica de organização do trabalho.

Segundo Lúcia Bruno:

Autogerir não significa apenas gerir de forma diferente um capital produtivo para que o seu produto venha a ser distribuído de maneira mais equitativa entre os trabalhadores. As práticas autogestionárias têm de realizar uma alteração profunda ao nível das relações de trabalho, destruindo os processos de valorização do capital. Ela não é um objetivo a se atingido na sociedade capitalista. A autogestão é um meio de luta, através do qual os trabalhadores se conscientizam de que são capazes de gerir a produção, de criar novas formas de organização do trabalho, de colocarem em prática a democracia operária (BRUNO, 1990, p. 37).

Assim, se a economia solidária ainda for um desejo, o papel político dos indivíduos deve começar a ser parte das agendas e das prioridades. Enquanto isto não ocorrer:

Os senhores da terra e os senhores do capital usarão sempre seus privilégios políticos para a defesa e perpetuação de seus monopólios econômicos. Em vez de a promoverem, continuarão a colocar todos 
os obstáculos possíveis no caminho da emancipação do operariado (MARX, 1988, p. 320).

Por outro lado, Luiz Inácio Gaiger sugere que para desenvolver a economia solidária e para ampliar as formas sociais não capitalistas, é fundamental renovar o modo material de produção, de forma que, esta nova economia não tenha que se submeter às racionalidades capitalistas, pois para ele, não é possível a convivência de ambos os modelos. Nesse sentido, entende que a economia solidária não se constitui em uma ameaça à reprodução da forma tipicamente capitalista, sendo que a "base técnica permanece intocada ou superficialmente inalterada" (GAIGER, 2003, p.9).

Neste caminho, o autor identifica oito princípios norteadores dos empreendimentos solidários: autogestão, democracia, participação, igualitarismo, cooperação no trabalho, autossustentação, desenvolvimento humano e responsabilidade social. Desta maneira, o fator diferenciador entre a economia solidária e a economia capitalista é a sua gestão democrática (FARIA, 2005; GAIGER, 2000).

O autor analisa que, atualmente, os empreendimentos cooperativos de autogestão experimentam uma dupla submissão à economia capitalista:

De um lado, estão sujeitos aos efeitos da lógica de acumulação e às regras de intercâmbio impostas ao conjunto dos agentes econômicos, de conteúdo eminentemente utilitário; de outro, como forma de responder à premissa de produtividade competitiva, estão compelidos a adotar a base técnica do capitalismo, os processos materiais de produção por ele introduzidos continuamente, configurando-se com isso uma subsunção formal inversa, de uma base sobre uma forma, similarmente ao caso da economia camponesa. Essas coerções, naturalmente, cerceiam a lógica econômica solidária, pois a obrigam a conviver com tensionamentos e a conceder em seu princípio (GAIGER, 2003, p. 201).

Nesse sentido, Gaiger entende ser necessário que a forma social se anteponha às formas capitalistas, dando lugar à produção solidária, impulsionando a cooperação entre trabalhadores, evidenciando e legitimando a lógica cooperativa frente às relações tradicionais de intercâmbio. Para isto, ele conclui que é necessário desenvolver políticas de fomento à economia solidária e motivar a população a formar parte deste novo circuito de produção.

Segundo sua concepção, a autogestão e a cooperação como elementos essenciais na economia solidária devem levar a uma reconciliação do trabalhador 
com as forças produtivas que ele detém e utiliza. No caso dos empreendimentos solidários, eles possuem o potencial de permitir que o produtor não se separe do produto de seu trabalho, e dessa forma, recuperaria o status que perdeu com a evolução do capitalismo, quando passou a ser considerado apenas como mercadoria e valor de troca (GAIGER, 2003). Neste caso, "o trabalhador recupera as condições necessárias, mesmo se insuficientes, para uma experiência integral de vida laboral e ascende a um novo patamar de satisfação, de atendimento a aspirações não apenas materiais ou monetárias" (Ibidem, 2003, p.193)

Desta forma, a economia solidária seria uma possibilidade com potencial para contrariar a forma social de produção assalariada, oferecendo novas formas do trabalhador se vincular com o produto do seu trabalho. Nesse sentido, para Gaiger (2007), a economia solidária não constitui um modo de produção e sim uma formação social com potencial para estender as formas sociais não capitalistas.

Por último, entre os críticos da Economia Solidária, ou pelo menos, do modo em que ela é concebida atualmente, destaca-se a posição de Quijano. Segundo o autor, o que hoje se denomina como economia solidária:

Es un heterogéneo universo de prácticas sociales que por su
demostrada capacidad de perduración y de reproducción, por su
creciente expansión mundial y por la magnitud de las poblaciones
implicadas, constituye una de las expresiones vitales del no menos
heterogéneo y contradictorio y conflictivo movimiento de la sociedad
actual, y, en esa medida, también un modo de las alternativas de los
dominados/explotados en el más sombrío período del capitalismo
global ${ }^{53}$ (QUIJANO, 2008, p. 12).

Para este autor, o sistema alternativo de produção sempre responde ao sistema capitalista, e neste sentido, afirma que o movimento cooperativista se insere no fim do século $X X$ em um cenário de reformismo capitalista, apenas como uma estratégia de aliviar a exploração dos trabalhadores e/ou para moderar a relação capital-trabalho (QUIJANO, 2002; NOVAES, 2004).

Segundo Quijano, os empreendimentos de economia solidária surgem:

Por iniciativa ou com o apoio de instituições de ajuda assistencial aos pobres (igrejas ou organizações não governamentais ligadas a elas, como a Caritas, etc.) subsistem e até parecem ajudar no desenvolvimento da convivência social dos seus membros em

\footnotetext{
${ }^{53}$ Tradução livre da pesquisadora - É um universo heterogêneo de práticas sociais que pela sua demonstrada capacidade de perduração e de reprodução, pela sua crescente expansão mundial e pela magnitude das populações envolvidas, constitui uma das expressões vitais do não menos heterogêneo, contraditório e conflitante movimento da sociedade atual e, nessa medida, também um modo das alternativas dos dominados/explorados no mais sombrio período do capitalismo global.
} 
direção a uma ética de solidariedade. Mas quase todas elas desintegram-se logo que é interrompida a ajuda financeira externa. $\mathrm{E}$ as muito poucas que sobrevivem transformam-se em pequenas ou médias empresas dedicadas, explicita ou conscientemente, ao lucro individual sob o controle e em benefício dos que administravam essas organizações "solidárias" (QUIJANO 2002, p. 496).

Mesmo com essas colocações, o autor não desconhece efeitos positivos que estas experiências possam obter, expondo que as advertências que faz ao assunto não devem diminuir em absoluto a importância que elas adquirem para ajudar a sobreviver a um grande contingente de população empobrecida ou, em outros casos, a fazer com que melhorem suas condições de vida. Porém, isto "não pode ir mais longe do que meras estratégias de sobrevivência” (QUIJANO, 2002, p.486), reduzindo a conotação transformadora que outros autores ponderam.

Em um trabalho anterior, Quijano chamava a atenção para o fato de que não há espaço para o desenvolvimento de uma economia alternativa se não se constrói uma estrutura de autoridade também alternativa, diferente das estruturas do Estado capitalista. Nesse sentido, expõe:

Quizá cabe, pues, esperar que la mayoría admita ya que dentro del actual patrón de poder, la sociedad no ha dejado de ser heterogénea y discontinua, que se mueve en varias direcciones aunque bajo la hegemonía de los que controlan el patrón de poder en su globalidad. $Y$ que en consecuencia tiene que optar entre esas varias direcciones u orientaciones, porque cada una de ellas implica modos diversos de existencia social. Optar entre esos modos y decidir cómo, de cuáles modos, con cuáles elementos actuales o posibles, se puede defender y hacer valer la opción elegida respecto de las otras, no sólo sabiendo que no hay garantía histórica ninguna de victoria, sino también sabiendo que no se lucha sólo por el éxito, sino, ante todo, por el valor que una opción de existencia social tiene para la historia de la especie, y por la cual no se puede, por lo tanto, dejar de luchar bajo cualquier circunstancia ${ }^{54}$ (QUIJANO, 1998, 15).

Neste sentido, como diz Leite, Quijano considera a economia solidária mais como uma declaração de intenções do que a afirmação de uma política (LEITE, 2009).

\footnotetext{
${ }^{54}$ Tradução livre da pesquisadora - Talvez caiba esperar que a maioria admita, já que dentro do atual padrão de poder, a sociedade não deixou de ser heterogênea e descontínua, que se movimenta em várias direções embora sob a hegemonia dos que controlam o padrão de poder em sua globalidade. E que em consequência tem que optar entre essas várias direções ou orientações, porque cada uma delas implica modos diversos de existência social. Optar entre esses modos e decidir como, de quais modos, com quais elementos atuais ou possíveis, é possível defender e fazer valer a opção escolhida a respeito das outras, não só sabendo que não há garantia histórica nenhuma de vitória, senão também sabendo que não se luta sozinho pelo sucesso, senão, ante tudo, pelo valor que uma opção de existência social tem para a história da espécie e pelo qual não se pode, portanto, deixar de lutar sob qualquer circunstância.
} 
As relevantes colocações do autor também refletem outros aspectos colocados ao longo deste trabalho, principalmente no que diz respeito à constelação de agentes que se reúnem em torno destas iniciativas, em seus diferentes papéis. Por um lado, as OSCs que ocupam um lugar fundamental no surgimento e permanência destes empreendimentos; por outro, as incubadoras universitárias que têm a finalidade de dar suporte à formação e ao desenvolvimento de cooperativas populares criadas por iniciativa de grupos de desempregados ou daqueles que vivenciam situações de precarização do trabalho (HECKERT, 2004). E finalmente, o papel que assumem os governos municipais e nacionais os quais começaram a intervir ativamente para efetivar experiências de economia solidária, em suas diferentes formas.

Exemplo disto são os casos do Brasil e Equador, analisados a seguir, que têm avançado sobre a inserção da Economia Solidária, em matéria de legislação, caminhando para incluí-la nos planos de governo.

Finalmente, é importante colocar que os traços assinalados acima não pretendem dar conta da complexidade e controvérsias que há em torno da economia solidária. Teve apenas a intenção de desenhar uma visão geral da diversidade de olhares e posições que aparecem no debate da referida questão. Eles oferecerão embasamento para a discussão seguinte, quando serão abordados os mecanismos socioeconômicos que contribuirão, ou não, para o desenvolvimento de alternativas reais e sustentáveis às formas capitalistas de trabalho na América Latina.

\section{POLÍTICAS PÚBLICAS DE ECONOMIA SOLIDÁRIA: METAMORFOSE DA RELAÇÃO CAPITAL - TRABALHO?}

Como foram apresentadas anteriormente, as políticas sociais sofreram modificações no decorrer da história e no último tempo a sua função principal parece ser a de encontrar uma forma de minimizar os efeitos da política econômica, em um sistema no qual "la acumulación por desposesión debe ser compensada, necesariamente, por políticas sociales, porque estructuralmente la hegemonía del capital financiero genera exclusión y marginalización de la fuerza de trabajo"55 (ZIBECHI, 2010, p.34).

\footnotetext{
${ }^{55}$ Tradução livre da pesquisadora - A acumulação por desapropriação deve ser compensada, necessariamente, pelas políticas sociais, porque estruturalmente a hegemonia do capital financeiro gera exclusão e marginalização da força de trabalho.
} 
Porém, qual tipo de políticas sociais? Pois as que veem sendo desenvolvidas, de forma assistencialista, se dirigem apenas a compensar os estragos que gera a economia, sendo ineficazes, além de reproduzir e institucionalizar a pobreza (CORAGGIO, 2004).

O caminho parece ser segundo as tendências observadas no início do século $\mathrm{XXI}$, a de começar um percurso orientado a gerar capacidades produtivas e fortalecer a economia "desde abaixo" (ARROYO, 2009). Assim, muitas das propostas que surgem desde o Estado procuram fortalecer experiências de desenvolvimento local, que frequentemente são iniciativas dos próprios indivíduos ou de sujeitos coletivos, entendo que nem o método de "Distribuir para Crescer" que pregou a esquerda dos anos 70, nem a bandeira de "Crescer para Distribuir", da direita liberal, nem o "Concentrar para Crescer" do neoliberalismo são suficientes para dar conta da intensidade e da profundidade do problema da exclusão (DAGNINO, 2004).

Este cenário reforça a hipótese estabelecida no início da pesquisa de que as "novas formas" de atender a emergência, assim como de conceber as políticas públicas, estão diretamente vinculadas com as estratégias de produção e reprodução mencionadas acima e com o modo de funcionamento que o Estado adota, conforme o capitalismo amadurece.

O caráter redistributivo emergencial adotado pelos governos latinoamericanos no último tempo não consegue dar um passo a frente e faz da emergência uma situação permanente, insustentável. Nesta encruzilhada, surge a possibilidade, através da economia solidária, de agregar aos programas de renda condicionada a implementação de modelos mais amplos de geração de emprego e renda por meio da promoção do trabalho associativo e por conta própria, de modo a encontrar um caminho alternativo para o desenvolvimento das economias periféricas. Isto implica também o estabelecimento de novas relações entre sociedade e estado, mediadas em grande medida pelos movimentos sociais.

A inovação nas formas em que começa a ser concebida a política pública apresenta novos desafios para os movimentos sociais, convertidos em canais por meio dos quais o Estado chega aos territórios de baixa renda, sendo co-construtores de políticas públicas.

Assim, a responsabilidade pelo sucesso ou pelo fracasso das novas ações é também compartilhada, tendo os movimentos sociais na forma de organizações 
sociais "de relanzar un nuevo ciclo de luchas que abra las puertas para la superación del modelo extractivista que genera exclusión, polarización social y reduce el sistema democrático a un mecanismo de validación electoral de los equipos gobernantes" 56 (ZIBECHI, 2010, p. 32).

Nesse sentido, tiveram de inovar nos seus interesses e nas suas formas de agir visando se adaptar aos novos emergentes. Calderón e Jelin analisam que houve mudanças nas categorias temáticas dos novos movimentos sociais (PATEO, FORTETE, 2011) orientando-se para o:

Fortalecimento das unidades produtivas ou reprodutivas de pequena escala: oficinas artesanais, pequenos comércios, unidades ou associações de consumo, pequenas unidades produtivas diversificadas em espaços urbanos e/ou rurais, etc., que de alguma maneira buscam ideologias e formas de organização autogestionárias (CALDERÓN E JELIN, 1987, p. 13).

Assim, o que se inicia como uma experiência dos movimentos sociais, com apoio de OSC, sindicatos, incubadoras universitárias, instituições religiosas irá ganhar espaço, fundamentalmente, nos primeiros anos do século $X X I$, no terreno governamental, e com o tempo, as práticas incipientes de economia solidária se materializarão em política pública de geração de trabalho e renda.

Neste caso, a cooperação entre atores seguirá a linha iniciada na década de 90, com traspasso de recursos e funções que foram públicas para o setor privado, porém, soma-se a ingerência do Estado como um ator que toma para si ações que já estão sendo desenvolvidas por outros atores. Nesse sentido, "o fetiche do Estado é reforçado justamente porque a classe dirigente - num determinado momento histórico - tem de exercer o poder em seu próprio interesse de classe, mas camufla suas ações como sendo para o 'bem de todos', para a 'nação', para o bem estar do 'povo'." (NOVAES, 2011, p. 170).

Neste sentido, quando se analisa a economia solidária nas suas diversas dimensões, observa-se que se trata de um movimento social nascido contra o modelo, que passa a ser, atualmente, promovido como estratégia e política de desenvolvimento (ZIBECHI, 2010).

Nesse sentido, segundo Schiochet,

\footnotetext{
${ }^{56}$ Tradução livre da pesquisadora - De relançar um novo ciclo de lutas que abra as portas para a superação do modelo extrativista que gera exclusão, polarização social e reduze o sistema democrático a um mecanismo de validação eleitoral das equipes governantes.
} 
Uma conjuntura permeada pelo desemprego, precarização, exclusão, desigualdade, descenso da luta social e política neoliberal compõe o contexto da expansão da economia solidária, das experiências econômicas concretas, empreendimentos econômicos solidários e da crescente opção dos movimentos sociais, sindical, universidades e organizações populares por uma nova forma de luta social, a partir da organização econômica das pessoas (SCHIOCHET, 2011, p. 445).

De acordo com o exposto, cabe assinalar que estas mudanças se dão na América Latina em um contexto inédito politicamente, onde muitos países são representados (em um mesmo período) por governos de esquerda, justo após o início do período das grandes reformas neoliberais. Trata-se de governos que são legitimados pela maioria da população, a julgar pelos resultados que permitiram a reeleição seja do mesmo representante ou nos casos em que a legislação não o permitisse, pela permanência do partido no poder. $E$ trata-se também de governos que assumem como bandeira a gestão da emergência que incentiva "el desarrollo de diferentes capacidades que, si bien son propias de la gestión pública, no es habitual verlas en conjunto desplegadas en el campo de la política social" 57 (CLEMENTE E GIROLAMI, 2006, p. 92).

Assim, por meio destas iniciativas, o Estado começará a se ocupar por um setor da população com o qual não tinha se vinculado antes: a parcela de trabalhadores informais, que cresce desde o fim do século XX. Dessa forma, a economia solidária se tornou uma alternativa de inserção produtiva para muitos trabalhadores, alguns dos quais engrossaram as filas dos desempregados desde há muito tempo (CUNHA, 2007).

Entretanto, para legitimar este novo trabalhador, é necessário criar um novo cenário que demonstre as vantagens e atrativos de se converter em um "empresário de si mesmo". Neste sentido, e frente à emergência destes acontecimentos, o Estado pactua com o setor privado (empresarial e filantrópico) e com o âmbito familiar-comunitário, no desenvolvimento e na validação destas novas estratégias, fortalecendo o próprio Estado (PATEO, FORTETE, 2011). Desta forma, se tece no território o que se poderia desenhar como um "amplio tejido de contención al que se sumaron progresivamente actores sociales hasta el momento ausentes, como los

\footnotetext{
${ }^{57}$ Tradução livre da pesquisadora - O desenvolvimento de diferentes capacidades que, embora sejam próprias da gestão pública, não é habitual vê-las em conjunto espalhadas no campo da política social.
} 
empresarios y los gremios, y otros que estaban actuando desde la protesta, como el movimiento de desocupados"58 (CLEMENTE E GIROLAMI, 2006, p. 86).

Na prática, o Estado participa promovendo a ampliação do capital social por meio de apoio técnico e financiando outros atores que possam contribuir com capacitação e formação para os trabalhadores, e também com capital financeiro, isto é, apoio econômico e legislação que permita incluir estes sujeitos no campo da formalidade. Desta forma, tem a responsabilidade de fortalecer junto à sociedade civil os espaços associativos para a resolução de problemas de ordem local (ARROYO, 2009), aproveitando sua capacidade de canalizar ideias e recursos aos grupos e comunidades, ao mesmo tempo em que serve como intermediário destes com o mundo externo (CUNHA, 2007).

Se por um lado esta "conquista" pode ser vista como uma oportunidade de expandir em maior escala, o que em princípio seria uma iniciativa local que testaria uma nova relação entre capital-trabalho, por outro pode implicar na institucionalização destas estratégias perdendo, principalmente, o mérito da autonomia e a diferenciação. Segundo Coraggio, além de pretender institucionalizar os valores de solidariedade, "estamos buscando un nombre para una variedad de prácticas de construcción de formas económicas no capitalistas que intentan resolver el acuciante problema del sustento cotidiano inmediato" 59 (CORAGGIO, 2008, p. 8).

Nas andanças do imediatismo, corre-se o risco de permitir nova cooptação dos movimentos sociais que, frente às demandas cotidianas, encontram alianças estratégicas e podem facilmente esquecer de atentar para as entrelinhas da exploração e a desigualdade.

Nesse sentido, é difícil imaginar como o coração dos movimentos sociais se mantém latente quando tão seduzido pelas estratégias que lhes apresenta o Estado, e é fácil de compreender quando se pensa que demandas urgem e soluções devem de ser encontradas fazendo das alianças um instrumento. Ou como expressa Zibechi, "El problema más grave, que a menudo obtura la comprensión del dispositivo, es que las mallas de la dominación están tejidas ahora con las mismas

\footnotetext{
${ }^{58}$ Tradução livre da pesquisadora - Amplo tecido de contenção ao que se somaram progressivamente atores sociais até o momento ausentes, como os empresários e os sindicatos, e outros que estavam atuando a partir do protesto como o movimento dos desempregados.

${ }^{59}$ Tradução livre da pesquisadora - Estamos buscando um nome para uma variedade de práticas de construção de formas econômicas não capitalistas que tentam resolver o urgente problema do sustento cotidiano imediato.
} 
hebras que sustentaron la resistencia: los movimientos troquelados como organizaciones" ${ }^{\prime 60}$ (ZIBECHI, 2010, p.41). Sem conflito nas veias não é possível falar de movimento social e difícil pensar em emancipação.

A partir do exposto, pode-se assinalar que as políticas públicas de economia solidária são uma oportunidade que o Estado abraça para gerar novos canais de atenção das demandas insatisfeitas, e por isso, a participação do Estado neste contexto merece uma ampla reflexão e o cuidado necessário para que esta nova forma de atuar não vire um meio para "despolitizar a pobreza e a desigualdade transformando-as em 'problemas de administração"' (ZIBECHI, 2010; DE OLIVEIRA, 2007).

Para que as políticas públicas de economia solidária não sejam apenas formas de reproduzir as relações históricas de caridade e do assistencialismo, buscando novamente controlar as ações dos movimentos sociais (EID, 2003), é necessário que estas sejam capazes de "conformar um ciclo interativo e realimentado que combine as dimensões redistributivas e emancipatórias com os ideais de justiça social e desenvolvimento econômico" (DAGNINO, 2004). Se assim não for, elas só se converterão em táticas para retardar o processo de ruptura com o sistema, contribuindo para a gestão da crise capitalista fazendo novos pactos sociais (EID, 2003).

Assim, se as políticas de economia solidária se constituem, única e principalmente, em estratégias para minimizar a pobreza, terão um mérito nada desdenhável de melhorar as condições de vida de uma porção da população, porém carecerão do status de transformadoras, representando apenas uma metamorfose da relação capital-trabalho, mas não a sua superação.

\subsection{A ECONOMIA SOLIDÁRIA NO BRASIL}

O Brasil pode ser considerado um dos países da América Latina que mais tem explorado o desenvolvimento da economia solidária, inspirando a disseminação da experiência para outras regiões. As primeiras iniciativas se deram no âmbito estadual e municipal, inauguradas no Rio Grande do Sul, sendo que as primeiras

\footnotetext{
60 Tradução livre da pesquisadora - O problema mais grave, que geralmente obtura a compreensão do dispositivo, é que as malhas da dominação agora são tecidas com os mesmos fios que sustentaram a resistência: os movimentos carimbados como organizações.
} 
experiências de ações governamentais podem ser encontras em Porto Alegre, Belém, Santo André, Recife e São Paulo (PRAXEDES, 2009).

Entretanto, antes de começar a se falar em economia solidária, aconteciam no país, experiências importantes de cooperativismo. Estas iniciaram-se no meio rural, porém adquirem relevância no meio urbano na década de 1980, proliferandose na década de 1990, recuperando a herança do século XIX, porém sob novas bases. Assim, as cooperativas nasciam em um ambiente democrático que se iniciava no país, e trazia junto, uma crescente preocupação pelas questões do mundo do trabalho, fundamentalmente, o desemprego (LEITE, 2009).

Estas iniciativas partiam principalmente dos trabalhadores que enxergavam esta nova organização como uma forma de resistência, mas também, e principalmente, como uma maneira de fazer frente aos efeitos do desemprego, e assim, deram início a novas formas de manter os postos de trabalho nas indústrias, já não mais como funcionários e sim como associados. Torna-se, assim, uma oportunidade para se repensar a autogestão e a organização coletiva, isto é, as relações entre o capital e o trabalho.

Desta forma, o desenvolvimento da economia solidária no Brasil resulta:

Da sinergia entre dois processos históricos, um econômico e um social. O primeiro refere-se à reestruturação produtiva em conjunto com a reforma de Estado e as consequentes alterações no mercado de trabalho, já que tiveram como consequência o surgimento de um excedente de trabalhadores que se juntou aos tradicionalmente excluídos. O segundo processo - social - refere-se à experiências acumuladas por atores sociais no campo da organização popular, tais como movimentos sociais, organizações não-governamentais, partidos políticos, universidades e setores vinculados a Igreja católica (PINHEIRO, 2010).

Neste sentido, Leite (2009) menciona quatro iniciativas que considera os pilares fundamentais da economia solidária no Brasil. A saber: (1) A criação de incubadoras de cooperativas por todo o território, por parte da Caritas, a partir de 1990; (2) o nascimento da Associação Nacional de Trabalhadores em Empresas de Autogestão e Cogestão (ANTEAG) para assessorar tecnicamente projetos que estavam sendo desenvolvidos neste âmbito; (3) o surgimento das incubadoras universitárias a partir de 1998, que possibilitaram a disseminação e transferência de tecnologias e conhecimento entre as Universidades e os grupos de autogestão, e, finalmente; (4) a atuação da CUT, que possui três entidades que fomentam a economia solidária: a Agência de Desenvolvimento Solidário (ADS), a Central de 
Cooperativas e Empreendimentos Solidários (UNISOL) e a Cooperativa Central de Crédito e Economia Solidária (ECOSOL) ${ }^{61}$.

Pouco tempo depois, com o Brasil sedeando o Primeiro Fórum Social Mundial, no ano de 2001, entra na lista dos países com terra fértil para legitimar e desenvolver com mais força, projetos de economia solidária, que cativam a participação de OSC e movimentos sociais, porém que exigem também o envolvimento do Estado.

Motivados pela organização destes movimentos entorno de uma maior disseminação das experiências de economia solidária, e com a intervenção do Fórum Brasileiro de Economia Solidária (FBES), um espaço de articulação da sociedade civil, em junho de 2003, no segundo governo Lula, cria-se a Secretaria Nacional de Economia Solidária ${ }^{62}$ (SENAES/MTE), dentro da estrutura do Ministério do Trabalho e Emprego. Não casualmente, o seu Secretário Nacional é Paul Singer desde o início da função e que se mantém no cargo até a atualidade e quadro técnico da SENAES é composto por funcionários provenientes da Incubadora Tecnológica de Cooperativas Populares da USP (Universidade de São Paulo), do Programa de Economia Solidária do Rio Grande do Sul (SEDAI/RS), de outras universidades, igrejas e movimentos sociais (FARIA, 2005).

Singer menciona que a Secretaria surge:

Como defesa contra a exclusão social e a queda na indigência, as vítimas da crise buscam sua inserção na produção social através de variadas formas de trabalho autônomo, individuais e coletivas. Quando coletivas, elas optam, quase sempre, pela autogestão, ou

\footnotetext{
${ }^{61}$ Para aprofundar sobre o assunto, ver M. Leite, Revista Brasileira de Ciências Sociais, Vol. 24. N 69. 2009.

${ }^{62} \mathrm{O}$ Decreto 5063 , de 08 de maio de 2004, estabeleceu as seguintes competências da SENAES: I - subsidiar a definição e coordenar as políticas de economia solidária no âmbito do Ministério do Trabalho e Emprego; II articular-se com representações da sociedade civil que contribuam para a determinação de diretrizes e prioridades da política de economia solidária; III - planejar, controlar e avaliar os programas relacionados à economia solidária; IV - colaborar com outros órgãos de governo em programas de desenvolvimento e combate ao desemprego e à pobreza; V - estimular a criação, manutenção e ampliação de oportunidades de trabalho e acesso à renda, por meio de empreendimentos autogestionados, organizados de forma coletiva e participativa, inclusive da economia popular; VI - estimular as relações sociais de produção e consumo baseadas na cooperação, na solidariedade e na satisfação e valorização dos seres humanos e do meio ambiente; VII contribuir com as políticas de microfinanças, estimulando o cooperativismo de crédito, e outras formas de organização deste setor; VIII - propor medidas que incentivem o desenvolvimento da economia solidária; IX apresentar estudos e sugerir adequações na legislação, visando o fortalecimento dos empreendimentos solidários; X - promover estudos e pesquisas que contribuam para o desenvolvimento e divulgação da economia solidária; XI - supervisionar e avaliar as parcerias da Secretaria com outros órgãos do Governo Federal e com órgãos de governos estaduais e municipais; XII - supervisionar e avaliar as parcerias da Secretaria com movimentos sociais, agências de fomento da economia solidária, entidades financeiras solidárias e entidades representativas do cooperativismo; XIII - supervisionar, orientar e coordenar os serviços de secretaria do Conselho Nacional de Economia Solidária; XIV - apoiar tecnicamente os órgãos colegiados do Ministério do Trabalho e Emprego, em sua área de competência; e XV - articular-se com os demais órgãos envolvidos nas atividades de sua área de competência.
} 
seja, pela administração participativa, democrática, dos empreendimentos. São estes os que constituem a economia solidária. (SINGER, 2004, p. 1).

Nesse sentido, o texto considera a economia solidária como:

O conjunto de atividades econômicas - de produção, distribuição, consumo, poupança e crédito - organizadas sob a forma de autogestão, isto é, pela propriedade coletiva do capital e participação democrática (uma cabeça um voto) nas decisões dos membros da entidade promotora da atividade (SENAES/MTE, 2003. p. 7).

Entre os fatores que influenciaram a formação desta Secretaria encontram-se os programas regionais de economia solidária. Por um lado, o Programa Oportunidade Solidária levado a cabo pela Secretaria do Desenvolvimento, Trabalho e Solidariedade (SDTS) da Prefeitura de São Paulo, que teve lugar durante a gestão petista de Marta Suplicy nos anos 2001 a 2004; e por outro, a experiência do governo do Rio Grande do Sul, chamado Programa de Economia Popular Solidária realizado entre os anos 1999 e 2002 com o governo Olívio Dutra, no âmbito da Secretaria do Desenvolvimento e dos Assuntos Institucionais (SEDAI) (GAIGER, BESSSON, LARA, SOMMER, 1999).

Apesar de ambas as experiências apresentarem diferenças importantes entre si, as duas procuraram apoiar a constituição de "empreendimentos econômicos solidários", principalmente as cooperativas. No caso de São Paulo, a iniciativa também visava o apoio a empreendimentos individuais e buscava se vincular com os programas de redistribuição de renda implementados pelo governo local. No caso do Rio Grande do Sul, só apoiavam projetos coletivos, focando em empresas falidas com potencial de serem recuperadas e cooperativas (FARIA, 2005; POCHMANN, 1999).

Mesmo com suas diferenças, estas práticas influenciaram diretamente o desenvolvimento de uma política pública nacional sobre a economia solidária, e a SENAES, ao se constituir, estabelece os seguintes objetivos:

Objetivo geral: viabilizar e coordenar atividades de apoio à economia solidária em todo território nacional.

Objetivos específicos:

- Elaborar e propor medidas para a articulação de Políticas de Finanças Solidárias em suas múltiplas modalidades, ampliando a escala de suas operações, os serviços financeiros prestados e legitimando novas 
institucionalidades econômicas;

- Intervir na reformulação do arcabouço legal que regula as cooperativas e propor a adoção de um Estatuto do Empreendimento Autogestionário, que permita consolidar sua identidade, implementar um sistema de proteção a seus trabalhadores e orientar as ações de fiscalização;

- Difundir e fortalecer os empreendimentos autogestionários, com a promoção do desenvolvimento de tecnologia adequada; apoiar materialmente as agências de fomento da economia solidária; articular cadeias produtivas, ampliando a produção, distribuição e consumo dos produtos da economia solidária, apoiando o consumo ético e o comércio justo;

- Estimular e promover a produção de conhecimento voltado para a Economia Solidária, articulando para tanto políticas de educação e de pesquisa; definir um sistema de acompanhamento e de avaliação de seu desenvolvimento; disseminar experiências bem sucedidas e disponibilizar um sistema de informações ${ }^{63}$.

Para isto, define como estratégia: "fortalecer e divulgar a economia solidária nacional, mediante políticas integradas, visando a geração de trabalho e renda, a inclusão social e a promoção do desenvolvimento justo e solidário" (SENAES/MTE, 2003. p. 13).

Paralelamente ao surgimento da Secretaria, cria-se o Fórum Brasileiro de Economia Solidária, doravante FBES, que por meio de fóruns estaduais se conecta com a SENAES "com o compromisso de promover um intercâmbio qualificado de interesses econômicos, sociais e políticos, numa perspectiva de superar práticas tradicionais de dependência" (FBES, 2003). Vinculado a este, forma-se a Rede Nacional de Gestores Públicos de Economia Solidária, realiza-se a Conferência Nacional de Economia Solidária e se instala o Conselho Nacional de Economia Solidária.

Este conjunto de atores e iniciativas vem dando corpo à política pública de economia solidária no Brasil, que como foi mencionado, nasce como

resposta e/ou resistência dos setores organizados da sociedade civil
aos impactos das transformações econômicas e sociais para a
esfera do trabalho e suas repercussões para pior das condições de
grande parcela da população brasileira (GAIVIZZO, 2006, p. 39).
${ }^{63}$ Fonte: Ministério do Trabalho e Emprego / Secretaria Nacional de Economia Solidária, 2006. Disponível em
www.mte.gov.br. Acesso em julho de 2010. 
No entanto, é abraçada e desenvolvida pelo Estado brasileiro ao reconhecer na economia solidária uma possibilidade de desenvolver a capacidade produtiva da grande parcela da população que se encontra fora do mercado de trabalho.

\subsection{A ECONOMIA SOLIDÁRIA NO EQUADOR}

No caso do Equador, país escolhido para realizar a pesquisa (ao lado do Brasil), a Economia Solidária vem de longa data, encontrando seus antecedentes na forma de organização pré-incásica, no Tahuantinsuyo e nas formas de reciprocidade andina arraigadas nas comunidades indígenas, campesinas e nos bairros populares urbanos.

Já a partir da década dos 60, as experiências associativas adquirem visibilidade nas comunas e cooperativas, porém, é em 1970 que estes movimentos são impulsionados, principalmente, por OSC, movimentos sociais, igrejas e também com a participação do Estado, com experiências concretas como as cooperativas rurais e urbanas constituídas por famílias ou grupos indígenas que se valem do intercâmbio e da solidariedade para sobreviver aos impasses que apresenta o desenvolvimento do sistema capitalista.

$\mathrm{Na}$ atualidade, os empreendimentos solidários se encontram em todo o território, em suas diversas formas, porém se concentram na região da Serra, como consequência da densidade populacional e das prioridades de atores como as OSCs e a cooperação internacional.

Segundo Rosero e Regalado (2003), os atores destes empreendimentos podem ser classificados de acordo com suas características sociais (campesinos, pescadores, artesãos, mulheres, jovens); econômicas (trabalho por conta própria, multiemprego, baixa renda) e culturais (índios, afro-equatorianos, montubios e mestiços).

O surgimento da economia solidária no Equador se aproxima das outras iniciativas semelhantes que surgiram no continente, no que diz respeito ao contexto no qual ganha importância, e as razões que a legitimam se destacam com um importante diferencial: o sistema de economia solidária equatoriano está previsto e garantido pela Constituição Nacional a partir do ano de 2008. 
Nesse sentido, a legislação é avançada se comparada às regulamentações de outros países latino-americanos; vários artigos a mencionam, porém há de se destacar o art. 283, no qual expressa:

El sistema económico es social y solidario; reconoce al ser humano como sujeto y fin; propende a una relación dinámica y equilibrada entre sociedad, Estado y mercado, en armonía con la naturaleza; y tiene por objetivo garantizar la producción y reproducción de las condiciones materiales e inmateriales que posibiliten el buen vivir. El sistema económico se integrará por las formas de organización económica pública, privada, mixta, popular y solidaria, y las demás que la Constitución determine. La economía popular y solidaria se regulará de acuerdo con la ley e incluirá a los sectores cooperativistas, asociativos y comunitarios ${ }^{64}$ (CONSTITUCIÓN DE LA REPÚBLICA DEL ECUADOR, 2008).

Esta forma social que assume o Estado visa à transição para um modelo mais justo e solidário, apontando para a democratização dos meios de produção, a redistribuição de renda e o respeito pela natureza. No país chama-se de modelo sumak kausai, que significa modelo orientado ao "bom viver" (ROSERO E REGALADO, 2008). Desta forma,

La vida y el vivir han sido colocados como asuntos centrales: conectan tiempos, experiencias, visiones de futuro. Desde su pluralidad, tensiones y contradicciones, el desafío es encontrar el cauce institucional y social para transformaciones que proyecten el 'buen vivir' incipiente, embrionario de hoy hacia un futuro cierto (LEÓN, 2008).

Neste caminho, iniciado com a posse do Presidente Rafael Correa em 2007, começam as negociações para a criação de uma nova Constituição, que inclua reformas políticas e incorpore também reformas de cunho social. Para contribuir com este processo e fazê-lo, de fato, participativo, em novembro de 2007 se designou um novo ator: a Assembleia Constituinte. Esta contou com a participação de 130 membros eleitos por voto popular e assumiu funções legislativas, finalizando sua função em julho de 2008, com a aprovação do novo texto da Constituição para o qual foi instituída.

Neste contexto e em consonância com as diretrizes que apresenta a nova Constituição, no ano de 2009, criou-se o Instituto Nacional de Economia Popular y

\footnotetext{
64 Tradução livre da pesquisadora - O sistema econômico é social e solidário; reconhece ao ser humano como sujeito e fim, tende a uma relação dinâmica e equilibrada entre sociedade, Estado e Mercado, em harmonia com a natureza e tem o objetivo de garantir a produção e reprodução das condições materiais e imateriais que possibilitem o "bom viver". O sistema econômico se integrará pelas formas de organização econômica pública, privada, mista, popular e solidária e as outras que a Constituição determine. A economia popular e solidária se regulará de acordo com a lei e incluirá aos setores cooperativos, associativos e comunitários.
} 
Solidária (IEPS), por meio de um Decreto Executivo, e na estrutura do Ministério de Inclusión Económica y Social, com jurisdição nacional, pessoa jurídica e independência técnica, administrativa e financeira.

Desta forma, o IEPS é o responsável por organizar, aplicar e executar os programas e projetos relacionados à economia solidária. Segundo o mesmo decreto, o IEPS terá a missão de:

Impulsar el crecimiento y la consolidación de la economía popular y solidaria en el contexto del sistema económico previsto en la Constitución y estará integrado por la Subsecretaría de Desarrollo Social, la Dirección de Gestión y Desarrollo Comunitario, Dirección de Desarrollo Rural, Dirección Nacional de Cooperativas del MIES, Programa de Desarrollo Rural Territorial y el Proyecto de Desarrollo del Corredor Central del Ministerio de Agricultura $^{65}$ (MIES-IEPS, 2011).

Desta forma, o Estado equatoriano se mostra em uma posição ativa para o desenvolvimento deste tipo de economia, e sendo assim, elaborou e aprovou em abril de 2011, a Lei de Economia Popular e Solidária e Finanças Populares e Solidárias do Equador. Ao adquirir estas dimensões, a economia solidária não se limita as formas associativas populares, senão que inclui as formas públicas e formas de solidariedade assimétrica, próprias da filantropia empresarial e da ação de organizações da sociedade civil (CORAGGIO, 2007b).

Foi uma construção conjunta entre universidades, OSC, governo e pesquisadores, reunindo na sua construção, aproximadamente, 1800 representantes. A lei de economia solidária tem o objetivo de reconhecer, fomentar e fortalecer a economia popular e solidária e o setor financeiro popular e solidário equatoriano, além de estabelecer as normas para a sua constituição e funcionamento, assim como instituir a institucionalidade pública que exercerá o monitoramento e controle (MIES-IEPS, 2011).

Trata-se de uma lei que incorpora a regulamentação das organizações de finanças populares e da economia popular solidária e distingue quatro formas de organização: Setores Comunitários, Associativos e Cooperativistas, as três são coletivas, e as "Unidades Econômicas Populares", contêm a forma individual ou familiar de organização.

\footnotetext{
${ }^{65}$ Tradução livre da pesquisadora - Impulsar o crescimento e a consolidação da economia popular e solidária no contexto do sistema econômico previsto na Constituição e estará integrado pela Subsecretaría de Desarrollo Social, a Dirección de Gestión y Desarrollo Comunitario, Dirección de Desarrollo Rural, Dirección Nacional de Cooperativas do MIES, Programa de Desarrollo rural Territorial e o Proyecto de Desarrollo del Corredor Central do Ministério da Agricultura.
} 
É importante mencionar que a economia solidária no Equador, mesmo sendo regulamentada e promovida pelo Estado a partir de 2008, não nasce no país, como foi visto anteriormente, nesse período e sim muito antes. Nesse sentido, o que a Constituição traz é a possibilidade do Estado assumir "una política activa de desarrollo de la economía popular y solidaria como forma orgánica emancipadora de los trabajadores"66 (CORAGGIO, 2007) e junto com essa possibilidade, o desafio de “sortear la tentación burocrática de 'poner orden' en un mundo básicamente informal”"67 (CORAGGIO, 2007).

Neste contexto, é possível observar que tanto o Equador quanto o Brasil são países que estão se atendo à questão da economia solidária, a partir de uma visão política, construindo enquadramentos legais e efetivando alianças com os setores sociais, que deram origem a estas iniciativas. Na continuação desta pesquisa, serão analisadas duas experiências concretas de Bancos Comunitários de Desenvolvimento como iniciativas originadas na economia solidária que procuram caráter de política pública e vinculam os mais diversos atores, mencionados no decorrer da dissertação.

\section{FINANÇAS SOLIDÁRIAS E BANCOS COMUNITÁRIOS DE DESENVOLVIMENTO NA AMÉRICA LATINA}

Diversas são as instituições financeiras de caráter solidário que existem e se desenvolvem na América Latina, principalmente a partir da década de 80 , como anteriormente mencionado. Elas surgiram como resposta ao momento político e econômico pelo qual os países latino-americanos transitavam, promovendo a responsabilidade comunitária e individual, caraterística das ações neoliberais que se iniciavam deste lado do globo.

Neste contexto surgem iniciativas com pretensão de democratizar o sistema financeiro, as quais são chamadas de finanças solidárias. Em uma visão ampliada, procuram:

La adecuación de productos financieros a las necesidades básicas de la población y al fortalecimiento del trabajo social acumulado en cada territorio, dando prioridad a los excluidos del sistema bancario tradicional y constituyendo un eslabón de integración y sustentación

\footnotetext{
${ }^{66}$ Tradução livre da pesquisadora - Uma política ativa de desenvolvimento da economia popular e solidária como forma orgânica emancipatória dos trabalhadores.

${ }^{67}$ Tradução livre da pesquisadora - Sortear a tentação burocrática de pôr em ordem em um mundo basicamente informal.
} 
de una relación más duradera entre economía y sociedad. Relación construida bajo la protección de la ética y de la solidaridad para crear las condiciones para un desarrollo humano que necesariamente tendrá que ser integrado y sustentable ${ }^{68}$ (COELHO, 2004, p. 261).

Neste contexto, surgem os Bancos Comunitários de Desenvolvimento, doravante BCD, primeiro na Ásia e nos Estados Unidos e logo na América Latina, os quais procuram intensificar e multiplicar este tipo de prática econômica de caráter social.

Nascem no seio da economia solidária, como formas inovadoras de integração econômica e social, que permitiriam aos setores de baixa renda que habitam comunidades locais de alto risco voltar ao circuito da produção e do consumo, contribuindo com o ciclo da produção e reprodução da força de trabalho.

Entretanto, conceder-Ihes o status de "solucionadores" de todos os problemas econômicos de uma comunidade se torna tão atrativo quanto perigoso, mesmo que os resultados atingidos no curto prazo encorajem a considerá-los uma potencial fonte de desenvolvimento econômico local. Entendendo este como:

El empoderamiento de las capacidades locales, que posibilita a los agentes locales intervenir sobre si mismos (operar su propio desarrollo) principalmente el desarrollo económico basado en la búsqueda de acumulación local, la que es posible promoviendo la integración del tejido productivo local, elemento organizador del quehacer es el territorio ${ }^{69}$ (CEPESIU, 2009, p. 6).

Na América Latina se utiliza um grande leque de denominações para fazer referência a instituições financeiras solidárias, segundo suas características e regiões. Termos tais como Bancos Comunales, Bancos Comunitários de Desenvolvimento, Banca Comunal, Banco de Confiança, Bancomunal, Sistemas Autogestionados de Crédito Comunal (SACC) são os mais utilizados. Por terem diferenças muito sutis, às vezes escolhidas apenas por causa de regionalismos e preferências dos grupos, para este trabalho considerar-se-á a denominação Bancos

\footnotetext{
${ }^{68}$ Tradução livre da pesquisadora - A adequação de produtos financeiros às necessidades básicas da população e ao fortalecimento do trabalho social acumulado em cada território, priorizando os excluídos do sistema bancário tradicional e constituindo um elo de integração e sustentação de uma relação mais duradora entre economia e sociedade. Relação construída sob a proteção da ética e da solidariedade para criar as condições para um desenvolvimento humano que necessariamente terá que ser integrado e sustentável.

${ }^{69}$ Tradução livre da pesquisadora - O empoderamento das capacidades locais, que possibilitam aos agentes locais intervir sobre si mesmos (operar seu próprio desenvolvimento), principalmente o desenvolvimento econômico baseado na procura da acumulação local, a que é possível promovendo a integração do tecido produtivo local, elemento organizador dos afazeres no território.
} 
Comunitários de Desenvolvimento, pois se entende que atende aos aspectos principais que caracterizam este grupo de iniciativas.

Assim, definem-se os BCD como projetos de apoio a economias populares de municípios de baixo Índice de Desenvolvimento Humano que prestam serviço financeiro solidário em rede de natureza associativa e comunitária, voltados para a geração de trabalho e renda promovendo a economia solidária (MELO NETO, 2008).

As duas experiências analisadas diferem enquanto à metodologia utilizada, ao público alvo (algumas priorizam mulheres, têm as que trabalham apenas no setor rural ou apenas no urbano, e as que atendem a ambos) e, fundamentalmente, quanto ao tipo de agente que as gerencia. Existem os bancos que nasceram a partir de iniciativas pessoais e, posteriormente, se constituíram em OSC, os que foram criados por iniciativa de alguma corporação internacional e os que surgem no seio da própria comunidade local, como poderá se observar no transcurso da pesquisa.

Entretanto, o seu principal diferencial frente a outros tipos de finanças solidárias radica na importância concedida à comunidade. Mesmo nos casos onde a gestão inicial parte de grupos privados, com ou sem fins de lucro, os BCDs passam a ser de propriedade da comunidade a quem compete a responsabilidade de sua administração.

De acordo com Santos:

As atividades econômicas fornecem o sustento e incentivo material, enquanto o sentimento do vínculo e os processos de educação e integração social, gerados em torno delas fornecem a energia e o entusiasmo necessário para que os participantes persistam e a alternativa não desmorone ou se desvirtue (SANTOS, 2002, p. 65).

Os bancos comunitários de desenvolvimento se servem de diversas alternativas para providenciar formas de geração e ampliação de renda e têm como objetivo promover o desenvolvimento de territórios de baixa renda, através do fomento à criação de redes locais de produção e consumo.

Para esses fins, articulam-se o fundo de crédito solidário, moeda social circulante local, feiras de produtores locais e capacitação em economia solidária. Os BCDs financiam e orientam a construção de empreendimentos sócio-produtivos e de prestação de serviços locais, bem como o próprio consumo local. Além da disseminação de microcréditos com múltiplas finalidades conforme as linhas de crédito definidas por cada banco, o seu maior compromisso é com a construção de 
redes locais de economia solidária através da articulação de produtores, prestadores de serviços e consumidores locais (FRANÇA FILHO E SILVA JUNIOR, 2006).

De qualquer forma, por sobre todos esses aspectos, que às vezes assemelham ou se diferenciam, um banco comunitário que une - simultaneamente produção, comercialização, financiamento e formação da comunidade local se constitui no produto articulador das ações de organização, mobilização e capacitação dos territórios (SILVA JÚNIOR, 2006).

Observa-se como o comportamento do mercado encontra solidez no desempenho de outros agentes, sejam estes: Estado, instituições, comunidade ou indivíduos, que em conjunto vão fazendo com que a cadeia encontre novos elos que contribuem para o dinamismo do mercado, que incluem, sempre, consciente ou inconscientemente um comportamento de aceitação perante as formas que se apresentam, de forma mais ou menos atrativa, mais ou menos encoberta. A respeito disto, resulta significativa a reflexão que aparece no texto Freedom from Hunger, fazendo referência ao processo de trabalho realizado entre os $B C D$ e as comunidades.

Al ayudar a los pobres a manejar exitosamente sus propios grupos de autoayuda y ayudarse unos a otros para utilizar el crédito a fin de aumentar sus ingresos y comenzar a ahorrar, estos programas hacen que ellos participen en actividades vitales que mejoran su confianza, su autoestima y el control de su propio ámbito. Experimentan una transformación psicológica profunda que muchos escritores llaman hoy "empoderamiento": una transformación de la actitud que pasa del "no puedo" a "puedo". [...] los pobres aumentan su conciencia de la posibilidad de mejorar su vida ${ }^{70}$ (FREEDOM FROM HUNGER, 1996 apud WESTLEY GLENN D, 2003, p. 5).

Entretanto, mesmo que a concepção de finanças solidárias ${ }^{71}$ procure expandir as concepções de microfinanças que começavam a ser muito difundidas nas últimas décadas do século $X X$, a influência dos microcréditos não pode ser ignorada. Estes se tornaram as primeiras estratégias de cunho financeiro a se manifestarem como solução ante os altos níveis de pobreza e desemprego que afetavam cruelmente os

\footnotetext{
${ }^{70}$ Tradução livre da pesquisadora - Ao ajudar os pobres a conduzir com sucesso seus próprios grupos de autoajuda e se ajudarem uns aos outros para utilizar o crédito a fim de aumentar suas rendas e começar a poupar dinheiro, estes programas fazem que eles participem de atividades vitais que melhorem sua confiança, sua autoestima e o controle de seu próprio âmbito. Experimentam uma transformação psicológica profunda que muitos escritores chamam hoje de "empoderamento": uma transformação da atitude que passa do "não posso" ao "posso" [...] os pobres aumentam sua consciência da possibilidade de melhorar sua vida.

${ }^{71}$ As primeiras experiências surgiram na Europa nos séculos XVIII em Londres (Lending Charity) e durante o século XIX na Irlanda (movimentos de cooperativas de crédito) e na Alemanha, Irlanda e Itália (HOLLIS, 1998).
} 
países latino-americanos. Segundo o economista colombiano Jaime Villarraga e o filósofo argentino Emilio Pauselli,

A ideia de que o microcrédito constituía uma estratégia exitosa na superação da pobreza esteve unida ao predomínio de ideias denominadas neoliberais, que interpelavam a pobreza como um resultado da falta de acesso a mercados dessa população marginalizada, entendendo que a possibilidade destas de oferecer bens e serviços deveriam terminar com essa situação de marginalidade e o crédito se tornava uma condição imprescindível -e em muitos casos entendida como suficiente- para concretar essa oferta. [...] Desde esta visão, os pobres podem financiar o seu desenvolvimento (VILLARRAGA; PAUSELLI, 2006, p. 1).

O transcurso dos fatos demonstrou que o microcrédito por ele mesmo não resolveria as questões de fundo que estavam inseridas na realidade socioeconômica latino-americana. Com a disseminação desta estratégia haveria mais quantidade de produtores, porém, nada assegurava que haveria condições de consumir a produção, a menos que se criassem estratégias para fazer com que a oferta e a demanda efetivamente correspondessem. De acordo com Villarraga e Pauselli, "la idea de que los pobres resolverán su situación transformándose en individuos que pasen a competir entre sí para aprovechar las escasas oportunidades a su alcance es fantasiosa, cuando no malintencionada"72 (2006, p. 3).

\subsection{Influência que vem da Ásia}

O primeiro banco de microcrédito no mundo e também o que mais tem transcendido fronteiras fora é o Grameen Bank, fundado na década de 70 em Bangladesh por Muhammad Yunus ${ }^{73}$, e que serviu de referência para a criação de outras experiências similares nos outros continentes.

Segundo Yunus, a motivação para desenvolver esse projeto nasce da constatação dele e de mais um grupo de estudantes das dimensões que a pobreza e a fome estavam alcançando no país. De acordo com o autor mencionado, as pessoas que se encontravam em condições de pobreza extrema:

Não eram pobres por estupidez ou por preguiça, elas trabalhavam o dia inteiro, realizando tarefas físicas muito complexas. Eram pobres porque as estruturas financeiras de nosso país não tinham a

\footnotetext{
72 Tradução livre da pesquisadora - A ideia de que os pobres resolverão sua situação transformando-se em indivíduos que passem a competir entre eles para aproveitar as escassas oportunidades a seu alcance é fantasiosa, quando não, mal intencionada.

${ }^{73}$ Muhammed Yunus é um economista formado em Bangladesh, doutorou-se nos EUA e foi professor na Universidade de Dhaka. Em 2006 recebeu o Prêmio Nobel da Paz pela criação do Grameen Bank.
} 
disposição de ajudá-los a melhorar sua sorte. Era um problema estrutural e não um problema individual (YUNUS, 2001, p. 24).

O Grameen Bank é uma organização de microfinanças popular que concede créditos baseados na confiança mútua, participação e responsabilidade à população rural daquele país - fundamentalmente mulheres - com dificuldades de acesso aos canais tradicionais de crédito. Vale destacar que se trata de uma empresa privada lucrativa e não de uma organização social sem fins de lucro, como é o caso dos BCDs latino-americanos, que serão estudados a seguir. De acordo com Yunus, "o empréstimo do Grameen não é apenas dinheiro, é uma espécie de passaporte para a autodescoberta e a auto-exploração. Quem o recebe começa a explorar seu potencial e a perceber sua criatividade oculta" (Ibidem, p. 139).

Em linhas gerais, todas as receptoras dos recursos são responsabilizadas pelo reembolso, assim como, se tornam sócias do Grameen Bank. Os créditos não ultrapassam US\$200 e foram oferecidos na tentativa de dinamizar a economia local, mitigar a pobreza e incluir socialmente a população mais marginalizada daquele país. A taxa de inadimplência é de apenas 1,15\%. Segundo Yunus, as somas de dinheiro emprestado são pequenas, porém fazem a diferença para as pessoas que recebem o crédito, além de que, desta forma, podem ser pagos em pequenos montantes, sem criar dificuldades para o seu pagamento (YUNUS, 2001, p. 145).

O Grameen Bank tomou grandes dimensões e, desde sua fundação, emprestou o equivalente a 5,72 bilhões de dólares para 6,61 milhões de mutuários, $97 \%$ dos quais são mulheres ${ }^{74}$. Desde o início, o Grameen Bank priorizou a concessão de créditos para mulheres, já que eram as mais excluídas do mercado de crédito, além dos administradores entenderem que:

Ser pobre em Bangladesh é duro para todo mundo, mas é pior ainda quando se é mulher. $E$ quando as mulheres veem surgir uma possibilidade, por modesta que seja, de sair da pobreza, elas se revelam mais combativas que os homens. [...] $O$ dinheiro, quando utilizado por uma mulher numa família, beneficia mais o conjunto dos membros do que quando é utilizado por um homem (YUNUS, 2001, p. 116).

Os créditos são concedidos a grupos e não a pessoas de forma individual. Isto porque se entende que em grupo cada um dos integrantes se sentiria mais seguro, beneficiando-se do apoio e estímulo de todos. Além de que desta forma

\footnotetext{
${ }^{74}$ Informação disponível em http:// www.grameen-info.org >. Acesso em março de 2011.
} 
haveria maiores possibilidades de pagar o empréstimo, seja porque o grupo se faz cargo da dívida em caso de desistência de algum membro ou porque a coesão do grupo geralmente faz com que não haja renúncias.

Descobrimos inicialmente que a constituição de um grupo era
essencial ao sucesso de nossa empresa. Individualmente, um pobre
se sente exposto a todos os tipos de perigos. O fato de pertencer a
um grupo lhe dá uma sensação de segurança. O indivíduo isolado
tem a tendência a ser imprevisível e indeciso. Num grupo ele se
beneficia do apoio mais regular e ele passa a ser um financiado mais
confiável. A pressão mutuamente exercida - de modo às vezes sutil,
às vezes nem tanto - mantém os membros do grupo em
consonância com os objetivos mais amplos do programa de crédito.
[...] É difícil controlar indivíduos isolados, é muito mais fácil fazê-lo se
eles integram um grupo (YUNUS, 2001, p. 135).

No caso dos bancos comunitários que se desenvolvem na América Latina, existe a modalidade mista, onde o crédito é concedido para grupos, porém também podem acessar pessoas de forma individual.

O tipo de atividade econômica apoiada difere em cada caso. No caso do Grameen Bank, os empréstimos apoiam atividades de encadernação, recauchutagem de pneus, produção de cosméticos, brinquedos, perfumes, velas, sapatos, conservas, pães, barcos, relógios, refrescos, temperos, dentre muitos outros (YUNUS, 2001). "Queremos liberar a criatividade dos indivíduos, a fim de criar uma vida melhor para eles. Não pretendemos forçar as pessoas a fazer o que elas não querem" (Ibidem., p. 177).

Desta forma, os créditos são especialmente dirigidos para que as pessoas possam criar novas oportunidades de autoemprego, o que lhes permitirá consequentemente melhorar suas condições de vida. A experiência de Bangladesh mostra que há melhorias nas moradias, na alimentação e na vestimenta das famílias que participam do projeto, além de um aumento da autoestima e mudanças nas relações interpessoais e familiares. Este último é fundamentalmente importante ao considerar que se trata de uma população altamente submetida ao poder patriarcal e masculino, onde os direitos das mulheres são altamente vulneráveis.

O aspecto inovador dessa iniciativa inspirou indivíduos e instituições no mundo todo; atualmente há réplicas do Grameen em mais de 80 países. Na América Latina encontram-se na Argentina, Bolívia, Colômbia, México e Uruguai. No caso do Brasil, atualmente está em curso uma negociação entre bancos privados e 
organizações não governamentais para incorporar a metodologia, sem resultados definidos até o momento da pesquisa. No entanto, o Brasil conta com uma rede de bancos comunitários que teve início em 1998, com a implementação do Banco Palmas, no Ceará, objeto deste estudo.

Se bem que os BCDs vêm se desenvolvendo de forma heterogênea e nem todos seguem a metodologia do Grameen. Esta é uma experiência que marca o início de uma nova concepção de inclusão econômica dos setores de baixa renda e, de acordo com a perspectiva de quem pesquisa, nisso radica a sua importância e sua pertinência para a análise dos bancos comunitários latino-americanos.

\subsection{Influência que vem dos Estados Unidos}

Assim como Yunus, o americano John Hatch foi um ator importante no desenvolvimento de iniciativas de finanças solidárias e bancos de desenvolvimento comunitário e, em ambos os casos, as iniciativas provêm de motivações pessoais. Em 1984, Hatch trabalhava com agricultores bolivianos em um projeto da USAID desenvolvendo um projeto que oferecia empréstimos para pequenos produtores agricultores de baixa renda. O programa era atraente, pois não requeria garantias reais, como exigem os programas de crédito convencionais dificultando o acesso aos grupos pobres. Além desta vantagem, as taxas de juros eram adequadas e poderiam ser pagas pelos agricultores. O programa foi posteriormente conhecido como Banca Comunal.

A partir deste antecedente, em 1985, criou-se a Fundação para a Assistência Comunitária internacional $^{75}$ (FINCA), com sede em Washington, que dissemina até hoje a metodologia e conta com uma rede mundial de 21 países na América, Ásia, África e Europa. Na América Latina atua em El Salvador, Peru, Costa Rica, México, Equador, Nicarágua, Guatemala, Honduras e Haiti.

A missão da FINCA é proporcionar serviços financeiros aos empreendedores de baixa renda no mundo para que possam criar empregos, construir ativos e melhorar o seu nível de vida. Nesse sentido, a fundação exige a constituição de BCD para a concessão dos créditos, pois estes contribuem para melhorar o desembolso, cobrança, poupança interna e seguimentos de empréstimos (MENA, 2008).

\footnotetext{
${ }^{75}$ Nome original: Fundación para la Asistencia Comunitaria internacional
} 
Estes BCDs devem ser constituídos por pelo menos oito pessoas que possuam um empreendimento em funcionamento e morem há pelo menos um ano na mesma região, priorizando as iniciativas compostas por membros que se conheçam e se vinculem solidariamente. Além disto, prioriza-se a população feminina, já que, de acordo com o seu fundador, trabalhar com as mulheres garantiria o bem-estar das crianças e suas famílias.

O sistema inclui pequenos empréstimos, poupança, microsseguros e outros serviços não financeiros para população pobre, fechando o ano de 2010 com 765 mil clientes em nível mundial.

O BCD é gerenciado por uma comissão diretiva do próprio banco, a FINCA acompanha o andamento da iniciativa durante os seis primeiros meses, ou até eles se estabelecerem de forma independente, por meio de um assessor financeiro. Este assessor faz a divulgação do projeto na comunidade e realiza reuniões com os interessados, explicando a metodologia e os requisitos para a criação e funcionamento do BCD. Havendo interessados, constitui-se uma comissão diretiva e se abre uma carteira de poupança, pois cada sócio deverá começar com um pequeno investimento. Após estas primeiras instâncias, há uma capacitação na metodologia e, posteriormente, se concedem os créditos individuais. $O$ assessor acompanha as atividades semanal, quinzenal ou mensalmente, dependendo da região.

Os BCDs são frequentemente atraentes para a população pobre por exigirem requisitos de fácil cumprimento e prescindirem de garantias individuais. Também se premia o cumprimento, o que faz ter pequenos índices de inadimplência; assim, quem mantém o pagamento em dia recebe um montante maior no seguinte crédito, obtendo um fluxo constante de dinheiro. No mesmo sentido, entre os aspectos que interessam aos associados, encontra-se o fato do banco nascer e se desenvolver na própria comunidade e o acompanhamento por parte da FINCA ser feito in loco.

Abordados os antecedentes que, se entende, influenciaram a formação destas iniciativas na América Latina, no próximo capítulo analisar-se-á o caso concreto do Banco Palmas, no Estado de Ceará, no Brasil, e o caso da CEPESIU, organização social que dissemina pelo território equatoriano, a proposta de Iniciativas Populares de Inversión.

Ambas são experiências inovadoras em seus territórios, e na última década, adquiriram maior relevância em um contexto sócio-político e econômico que 
possibilita sua existência e disseminação. Trata-se assim de iniciativas de economia solidária que excedem a formação de cooperativas ou a organização de grupos produtivos,para serem uma prática associativa que envolve moradores em um determinado contexto territorial, os quais buscam a resolução de problemas públicos concretos relacionados à sua condição de vida no cotidiano, através do fomento à criação de atividades socioeconômicas (FRANÇA FILHO E SILVA JÚNIOR, 2006).

Desta forma, os BCDs constituem um sistema mais aprimorado que une relações de reciprocidade e solidariedade, escolhida ou instituída, com possibilidades de gerar emprego e renda para setores que se encontram fora do mercado de trabalho, utilizando as possibilidades que oferece a comunidade local onde os bancos comunitários surgem e se desenvolvem. 


\section{CAPÍTULO IV}

\section{EXPERIÊNCIAS DE FINANÇAS SOLIDÁRIAS NO BRASIL E NO EQUADOR: A REPRODUÇÃO NA PRÁTICA}

Neste capítulo, busca-se exemplificar, a partir de duas experiências práticas, a discussão abordada no decorrer da dissertação sobre as novas formas de produção e reprodução da força de trabalho e as relações de poder que as intermediam.

Para isso, neste momento, interessa analisar comparativamente duas experiências latino-americanas de BCD: o Banco Palmas do Brasil e o CEPESIU do Equador com seu programa de Sociedades Populares de Inversión. O primeiro está localizado na cidade de Fortaleza, no Estado de Ceará e o segundo tem sede em Quito, mas também atua em grande parte do território equatoriano.

$\mathrm{Na}$ continuação deste capítulo, far-se-á a descrição das principais características de cada experiência para, posteriormente, aprofundar nos elementos que as diferenciam e nas muitas questões que as aproximam, de forma a interligálas com os aspectos teóricos expostos no decorrer da presente dissertação.

\section{1. "SOMOS POBRES PORQUE NÃO TEMOS DINHEIRO": A HISTÓRIA DO BANCO PALMAS}

O Banco Palmas foi criado em janeiro de 1998 no Conjunto Palmeira, um bairro da periferia de Fortaleza, onde, atualmente, vivem aproximadamente 32.000 habitantes.

O Conjunto Palmeira se constituiu a partir de 1973 com moradores vindos de despejos realizados na região litorânea da cidade, a partir de uma ação de desapropriação realizada pelo poder público municipal que expulsou os pescadores da orla marítima e os alocou em três bairros da cidade, um deles, o Palmeira. Assim, os novos habitantes da região em situação de extrema pobreza, segundo contam os gestores do Banco Palmas, foram construindo suas casas de papelão ou plástico, resultando em uma grande favela, sem serviços básicos, tais como rede de saneamento, água tratada, energia elétrica, escola ou outro serviço público. 
A partir de 1981, fundou-se a Associação dos Moradores do Conjunto Palmeira (ASMOCONP) e dez anos depois, organizados em mutirões, deram início ao processo de urbanização. Assim, em 1991, realizaram um seminário chamado "Habitando o inabitável", que chamava a responsabilidade da comunidade e do poder público para melhorar a estrutura do local. Isto incluía a implantação das redes de água tratada e energia elétrica, canal de drenagem e a rede de esgoto sanitário, pavimentação das ruas, construção de praças e creches comunitárias.

Este processo também contou com a cooperação da Sociedade Alemã de Cooperação Técnica (GTZ), que possuía um programa de urbanização de favelas, para o qual selecionou algumas áreas, uma delas a do Conjunto Palmeira. Fato este que vem ao encontro da tendência que se vivenciava na década de 90 nos países latino-americanos sobre a intervenção de organizações internacionais, assunto abordado no capítulo II deste trabalho.

Em 1997, foi realizado outro seminário para avaliar o primeiro. Segundo conta Joaquim de Melo Neto, o fundador do Banco Palmas ${ }^{76}$, foi neste momento que perceberam que tinham conseguido urbanizar a favela em um período de sete anos, mas mesmo assim, muitas famílias estavam se mudando para outras comunidades. A partir desta constatação, a Associação realizou uma pesquisa na qual, segundo uma moradora:

\begin{abstract}
Identificamos que $30 \%$ das famílias tinham menos de dois anos de residência no bairro. Isso trazia à tona uma realidade nova: os moradores do Conjunto Palmeira, que durante 20 anos lutaram pela urbanização, não podiam mais viver no próprio bairro que construíram. Antes não existiam taxas de luz, água, esgoto, telefone ou IPTU. Agora, tudo fazia com que morar no Palmeira fosse luxo para uma população desempregada, vivendo de biscates $\mathrm{e}$ subempregos (NETO II E MAGALHÃ̃ES, 2008. p. 16).
\end{abstract}

Com estes dados, a ASMOCONP que desde a sua criação possuía experiência de mobilização e de luta, como tantas outas organizações que surgem na década de 80 , entende que o fim da década de 90 exigia dela uma nova posição. Resolve iniciar um processo de geração de emprego e renda porque do contrário, os moradores não conseguiriam permanecer na comunidade.

Era o momento no qual:

\footnotetext{
76 Entrevista realizada a Joaquim de Melo Neto pelo Museu da Pessoa. Disponível em: http://www.museudapessoa.net/MuseuVirtual/hmdepoente/depoimentoDepoente.do?action=ver\&idDepoenteHom e $=11204 \&$ key $=7821 \&$ forward=HOME_DEPOIMENTO_VER_GERAL\&tipo $=\&$ pager. offset $=4$
} 
A questão social que caracterizava a conjuntura nacional na década de 1990 tem seu contexto permeado pela derrota do projeto democrático popular (com perspectivas de reformas estruturais profundas) em 1989 e com consequente descenso da luta de massas, a desmobilização e fragmentação do movimento sindical e popular (SCHIOCHET, 2011, p. 444).

Nesse sentido, as primeiras consequências do novo modelo econômico começavam a aparecer no país e se manifestavam também no nordeste, território historicamente punido pelas leis naturais e o esquecimento do governo central.

Diante desse cenário, a primeira ideia que teve a ASMOCONP foi promover a produção e o consumo local, fortalecendo o que havia na comunidade.

Não coincidentemente era o momento em que o Brasil começava a se aproximar do que, na sua fase mais avançada, foi chamado de Economia Solidária, "dando azo a um campo de experiências e iniciativas de produção e reprodução dos meios de vida estruturados a partir da propriedade coletiva dos meios de produção, da autogestão, da solidariedade e do coletivismo" (FARIA E SANCHEZ, 2011, p. 413).

Estes exemplos que se observam na prática, além de mostrar o papel fundamental que as organizações da sociedade civil tiveram no desenvolvimento da economia solidária, trazem um elemento importante para a discussão: é a crise e o desemprego que impulsionam estas estratégias e não a consciência de que o capitalismo é um sistema manco e que só serve a uma parte da população. Evidentemente, isto não tira os seus méritos, mas invalida muitos dos discursos que fazem com que se encontre na economia solidária a receita para um bolo que não pretende ser dividido

Joaquim de Melo Neto II, em diversas palestras e apresentações que realiza, costuma dizer que a pergunta que se faziam na época era: Por que nós somos pobres?

Os moradores respondiam: "Somos pobres porque não temos dinheiro". Era tão óbvio que não podia ser verdade. Daí, então, fizemos o Mapa da Produção e do Consumo. Saímos perguntando para as famílias o que elas consumiam e em que quantidade, qual a marca dos produtos e em que local realizavam suas compras. O resultado desse mapeamento nos mostrou que mensalmente os moradores consumiam em produtos, ou seja, gastavam com alimentação, vestuário, produtos de limpeza e de higiene e beleza, um total de $\mathrm{R} \$ 1.200 .000,00$ (um milhão e duzentos mil reais). $\mathrm{O}$ problema era que todas as compras eram feitas fora do bairro. Então dissemos para os moradores: não somos pobres porque não temos 
dinheiro, e sim, porque perdemos nossa base monetária, ou seja, perdemos o dinheiro que temos ${ }^{77}$.

A partir deste movimento, a ASMOCONP se propõe a iniciar um projeto de geração de emprego e renda que juntasse duas dimensões: o estímulo à produção local por meio de financiamento em formato de microcrédito e a promoção do consumo local através de um cartão de crédito. Desta forma, o desafio era fazer com que o consumo local resultasse tão atrativo quanto o consumo fora da comunidade. De acordo com Neto II e Magalhães, a maneira como se faz o consumo define o tipo de sociedade que se quer construir, e expressam: "Consumir não é somente uma atitude econômica, é, também, uma atitude política. Quando consumimos produtos feitos na comunidade, estamos gerando trabalho e renda para os moradores do bairro" (NETO II E MAGALHÃES, 2008, p. 16).

Mas, para produzir localmente, era necessário ter um capital que permitisse essa produção, e assim surgiu a ideia de fazer um Banco. De acordo com informação dos gestores, após aproximadamente 40 reuniões realizadas entre moradores e a ASMOCONP, deu-se início ao Banco Palmas, em 1998. Tratava-se de um Banco popular que tinha como missão: implantar programas e projetos de trabalho e geração de renda, utilizando sistemas econômicos solidários, na perspectiva de superação da pobreza urbana (NETO II E MAGALHÃES, 2008).

Os conhecimentos para se iniciar este projeto provinham do que os moradores sabiam deles mesmos e de seus vizinhos, da realidade que lhes pertencia, e da miséria que lhes afetava a cada dia. Resulta ilustrativo o discurso de Neto II e Magalhães ao expressarem:

Somente a convivência cotidiana com as contradições geradas pelas situações de extrema exclusão é capaz de possibilitar conhecimento e sabedoria para se fazer, de forma eficaz, a mais desafiadora de todas as gestões: a gestão da pobreza [...] A todo momento chegavam na Associação pessoas desempregadas, alcoólatras, desabrigados, famílias passando fome, jovens drogados, mulheres sem nenhuma formação profissional, analfabetos e outros completamente à margem do mundo do trabalho. Todos a procura de uma alternativa de vida (2008, p. J - I 16).

\footnotetext{
${ }^{77}$ Informação obtiva de entrevista realizada pelo Instituto Ressoar a Joaquim de Melo Neto II. Disponível em <http://www.ressoar.org.br/dicas_sustentabilidade_bancos_comunitarios_entrevista.asp >. Acesso em março de 2011.
} 
Além disso, as inspirações provinham da Teologia da Libertação e dos estudos de Paul Singer, principalmente de suas iniciativas de cooperativismo que tinham iniciado no país na década de 80 , como foi visto no capítulo II deste trabalho.

Assim que a ASMOCONP decidiu criar o Banco Palmas, foi em busca de capital para iniciar a atuação, primeiramente se dirigiram à Prefeitura da cidade e depois ao Governo do Estado, sem sucesso. Foi a ONG Ceará Periferia, também da cidade de Fortaleza, que emprestou $\mathrm{R} \$ 2.000,00$ com os quais iniciaram sua carteira de créditos. Este recurso vinha do Fundo de Apoio a Projetos de Autogestão FAPAG direcionado a iniciativas de associações comunitárias. Era um empréstimo e, portanto, devia ser reembolsado no prazo de um ano, pagando $1 \%$ de juros. 0 montante deu para apoiar os cinco primeiros clientes, e não havia mais dinheiro a ser emprestado. Tempos depois, os tomadores de crédito pagaram e a Agência Alemã de Cooperação Técnica, a ONG Internacional $\mathrm{OXFAM}^{78}$ e a cooperação internacional forneceram recursos para continuar a atividade.

Assim, tinha-se o cartão de crédito e um pequeno montante destinado aos empréstimos. Posteriormente, surgiram grupos produtivos que foram apoiados pelo Banco, assim organizaram-se pequenas empresas as quais serão descritas no decorrer deste capítulo.

Não se desconhecem os efeitos positivos que estas formas de geração de emprego e renda tiveram nas comunidades de baixa renda e sua evolução enquanto estratégias de finanças solidárias. É importante abordar alguns aspectos que constituem a complexidade do assunto. A reflexão feita pela comunidade sobre a relação da pobreza com a esfera da distribuição merece fazer uma pausa. Entendese, que a questão não pode ser olhada apenas pela lente da distribuição, a pobreza não tem relação unicamente com a desigualdade distributiva, ela está diretamente vinculada com a exploração e a falta de acesso às fontes de dinheiro, isto é, à terra, ao trabalho, aos meios de produção. Se a análise não envolver estes elementos, confirmará o discurso neoliberal da responsabilidade individual, aceitando a falta de compromisso do Estado com a sociedade.

Afirmar que uma comunidade é pobre apenas porque o dinheiro de seus moradores não circula dentro dela é desconhecer a problemática que se inicia no

\footnotetext{
${ }^{78}$ A ONG Oxfam foi fundada na Grã-Bretanha em 1995 e é uma confederação internacional de 14 organizações não governamentais independentes, que trabalham conjuntamente com sócios e colaboradores em 98 países em ações dirigidas a diminuir a injustiça social.
} 
momento em que o trabalhador se divorcia dos seus meios de produção, e as consequências que este fato trouxe para a humanidade; e nesse sentido, é aceitar que a gestão da pobreza deve vir das próprias comunidades, instituições e gestores, provocando um consentimento coletivo que contribui para "assegurar a preservação de um tipo de predomínio econômico e político" (NOVAES, 2011, p. 181) que se mantém século após século.

\subsection{Os gestores do Banco Palmas}

\subsubsection{Para um banco, um banqueiro}

Como já foi visto, a existência de uma associação local possibilitou a criação de um Banco Comunitário de Desenvolvimento, porém, o papel e a trajetória do Joaquim de Melo Neto II, citado anteriormente e considerado o idealizador do Banco Palmas, desenha em grande medida, os rumos deste projeto.

Joaquim nasceu no ano de 1962, em Recife, morou em vários lugares do Brasil até se radicar em Belém, onde iniciou seu curso de seminarista e simultaneamente foi militante do Movimento da Libertação dos Presos do Araguaia. Filho de um funcionário público e uma dona de casa, conta que não sabe exatamente de onde nasceu sua motivação para o sacerdócio, mas disse que foi no seminário que encontrou espaço para a militância.

Com 22 anos foi morar em Fortaleza motivado pela possibilidade de trabalhar "pelos pobres", como ele mesmo conta, primeiro passou por outras comunidades de baixa renda até se instalar no Conjunto Palmeira e uniu-se ao trabalho da ASMOCONP.

Em 1998, formou o Banco Palmas e desde lá vem se desenvolvendo como líder comunitário que tem inspirado muitas iniciativas e pessoas, não só no Brasil, mas também pelo mundo.

Seis anos depois, havendo passado por outras experiências como a formação do Instituto Palmas e depois de o Banco Palmas ser conhecido e reconhecido pelos promissores efeitos que apresentava, em 2004, a organização internacional Ashoka, especializada em empreendedorismo social e com forte atuação no Brasil, o integra na sua rede. A partir desse momento, Joaquim é reconhecido como fellow de 
Ashoka, o que, segundo ele, abriu-lhe outros horizontes, gerando novas oportunidades para ampliar as parcerias.

Em 2008 foi finalista do Premio Empreendedor Social realizado pela Fundação Schwab, e recebeu durante esta última década diversos prêmios e reconhecimentos.

No decorrer desta trajetória, Joaquim tem sido o principal disseminador da ideia publicamente, e a figura mais conhecida e procurada quando se quer informação sobre o Banco Palmas. Morando no Conjunto Palmeiras até hoje, é quem apresenta a iniciativa no Brasil e em outros continentes, e é também quem recebe as mais diversas visitas feitas ao Banco Palmas. Forma parte da ASMOCONP desde que chegou ao bairro e também dirige o Instituto Palmas ${ }^{79}$.

Em entrevista concedida ao Jornal Folha de São Paulo, no ano de 2008, Joaquim expressava: "O Instituto Palmas é a minha vida. Abdiquei da vida pessoal, nunca tirei férias, não tive filhos, casei, descasei, casei de novo (...). Mas me considero privilegiado por conhecer minha missão"80.

Quando analisadas iniciativas deste tipo, é possível observar semelhanças entre os perfis dos idealizadores. Foram mencionadas no capítulo III as histórias de Muhammad Yunus e John Hatch, ambas inspiradas também em descobertas pessoais e desejos de mudança, experimentados após se depararem com situações de miséria e precarização. Isto demonstra também a identificação dos gestores com as causas que defendem e talvez isso explique a exposição deles como os principais e, às vezes, únicos disseminadores, mesmo que no discurso façam referência à gestão participativa e democrática dos bancos por parte de seus membros.

\subsubsection{Uma andorinha só não faz verão}

Além do papel principal que cumpre Neto II, a gestão e administração do Banco Palmas são realizadas pela ASMOCONP, e seu quadro de funcionários composto majoritariamente por voluntários.

\footnotetext{
79 O Instituto Palmas é uma organização da sociedade civil, responsável por disseminar a metodologia dos BCD. Mais informação sobre eles encontra-se no decorrer deste capítulo.

${ }^{80}$ Trecho de entrevista concedida por Joaquim de Melo Neto II à Folha de São Paulo. Disponível em www2.uol.com.br/empreendedorsocial/2008-joaquim.shtml. Acesso em setembro de 2011.
} 
A Associação entende que os gestores do Banco Palmas devem ser pessoas da própria comunidade, "tanto para viabilizar as ações do BCD como para gerar cidadania no próprio bairro". O desafio consiste em capacitar uma equipe local que possa responder às exigências técnicas de gestão que o Banco Palmas enfrente no seu cotidiano (NETO II E MAGALHÃES, 2008, p. 83).

Nesse sentido, a equipe administradora é capacitada pela Escola Comunitária de Sócioeconomia Solidária (Palmatech), um dos projetos que se derivam do Banco responsável pela gestão do conhecimento do Banco Palmas a partir da elaboração de materiais pedagógicos e publicações. De acordo com Marcos Arruda ${ }^{81}$ :

\begin{abstract}
A escola tem como valor central o controle da sociedade sobre a economia e o mercado como espaço de cooperação, colaboração e satisfação das necessidades humanas. Nela a comunidade aprende a organizar, planejar e administrar seu próprio desenvolvimento. Aprende a pôr em prática os valores da cooperação e da solidariedade no espaço familiar e local, e também a trabalhar e superar, através do respeito e aceitação do outro e do diálogo com ele, os desacordos e conflitos que aparecem naturalmente em toda relação entre pessoas e grupos humanos. [...] Isto dá à Associação e à comunidade poder para negociar com agentes governamentais buscando captar apoio e recursos sem arriscar perder o controle sobre a gestão do seu próprio desenvolvimento (ARRUDA apud NETO II E MAGALHÃES, 2008, p. 83).
\end{abstract}

Segundo integrantes da Associação, a formação de uma boa e permanente equipe administrativa também é um desafio latente na dinâmica dos bancos, pois muitas vezes não há na comunidade grande número de pessoas com bom nível de escolaridade e os recursos para pagar os salários não são suficientes, além de que, nem todas as pessoas possuem espírito dinâmico e comunitário, cooperativo e solidário, requisitos que a ASMOCONP considera fundamentais para formar parte da equipe.

\title{
1.2 Principais linhas de atuação do Banco Palmas
}

O Banco Palmas busca, como já mencionado, intervir no desenvolvimento da comunidade local e, por isso, desenvolve diferentes linhas de atuação: têm as que o aproximam mais de um Banco convencional e as que o caracterizam como um

\footnotetext{
${ }^{81}$ Marcos Arruda é sócio-economista e educador, coordenador geral do Instituto de Políticas Alternativas para o Cone Sul (PACS). Membro do Instituto Transnacional e da equipe internacional de animação do Polo de Sócioeconomia Solidária, da Aliança por um mundo responsável e solidário. Integra a secretaria do Fórum de Cooperativismo Popular do Rio de Janeiro.
} 
projeto social, pois no fim, é para o desenvolvimento local que surge e não para a especulação financeira.

Assim, podem ser identificadas quatro principais linhas de atuação, todas descritas a seguir: sistema integrado de microcréditos, microsseguros, empreendimentos produtivos solidários e projetos sociais.

\subsubsection{Sistema integrado de microcréditos}

Até a definição do marco legal no Brasil, no ano de 1999, o microcrédito era operado principalmente por iniciativas de ONGs, mas hoje são vários tipos de agentes financeiros que atuam no processo de intermediação do microcrédito: Agências de Fomento, Agente de Intermediação, Bancos Comerciais, Bancos Cooperativos, Bancos de Desenvolvimento, Cooperativas de Crédito, Instituições Financeiras Oficiais, Instituições de Microcrédito Produtivo Orientado, Organizações da Sociedade Civil de Interesse Público e Sociedade de Crédito ao Microempreendedor.

Cacciamali e Braga, em estudo realizado para o MTE no ano de 2002 informavam que o baixo desempenho dos programas de microcrédito se derivava da falta de prioridade no atendimento da população de baixa renda a não existência de linhas de crédito para a abertura de negócios (CACCIAMALI E BRAGA, 2002).

Já a partir de 2003, com o governo Lula
O conceito de acesso ao crédito passou a ser entendido como o conceito de microfinanças, em sentido mais amplo, principalmente com a bancarização das camadas mais baixas da população (base da pirâmide social) e a concessão de crédito indistintamente para consumo ou produção, pelo sistema financeiro nacional. Os bancos públicos - Caixa Econômica Federal, por meio do Caixa Aqui, e o Banco do Brasil, por meio do Banco Popular do Brasil - tiveram papel fundamental nesse processo, operando grande rede de correspondentes bancários, em padarias, mercados e farmácias, por meio de POS (point of sale) (BARONE E SADER, 2008, p. 1251).

Estas mudanças contribuíram com o sistema de créditos que vinha desenvolvendo o Banco Palmas, o qual se viu favorecido com o apoio financeiro das instituições mencionadas para ampliar suas linhas de crédito.

Desta forma, o Banco Palmas desenvolveu um sistema financeiro solidário, adaptado à realidade da comunidade, que atua de forma integrada nos quatro 
pontos da cadeia produtiva: capital solidário, produção sustentável, consumo ético e comércio justo (NETO II E MAGALHÃES, 2008).

O Banco de Palmas proporciona dois tipos de créditos: um para produção, introduzindo esta modalidade, não comumente encontrada em Bancos convencionais e outro para consumo. O primeiro atende aos pequenos empreendedores e o segundo viabiliza o consumo da produção que é gerada dentro da comunidade. Desta forma, se organizam os agentes econômicos locais fomentando o desenvolvimento da comunidade.

Para ter acesso às linhas de crédito, as pessoas devem ser moradores da comunidade e sócio ativo da ASMOCONP; ser reconhecido pelos vizinhos como uma pessoa responsável e assinar um contrato social com o Banco através do qual se compromete a comprar e vender no próprio bairro sempre que possível (NETO II E MAGALHAES, 2008).

Existem cinco linhas de crédito:

- Microcrédito para produção, comércio ou serviço. Este tipo de microcrédito é concedido para pequenos empreendedores que precisam de dinheiro para criar ou aprimorar seu negócio, porém não cumprem com as condições exigidas pelos bancos convencionais para concessão de créditos, no que tange a fiador, nível de renda, patrimônio e outras normas bancárias. As garantias cadastrais exigidas pelo Banco são as que pode oferecer a vizinhança; enquanto a responsabilidade, o nível de comprometimento e a experiência no ramo da atividade para a qual se pede o crédito são do tomador de empréstimo. Não são cobradas taxas administrativas e os juros variam de $0,5 \%$ a $3 \%$, segundo os valores do crédito concedido.

- Palmacard. A linha de microcrédito para consumo consiste na concessão de um cartão de crédito criado pelo Banco Palmas para estimular o comércio local, com funcionamento apenas no bairro. Não tem taxa de juro e o montante inicial pode ser aumentado de acordo com o cumprimento do pagamento. Segundo os idealizadores do Banco, a utilização do palmacard faz com que o dinheiro circule no próprio bairro e estimule as relações de solidariedade entre produtores e consumidores locais. Por outro lado, ao ser aceito por diversos comerciantes do bairro, estes permitem o acesso imediato a bens e serviços mesmo sem possuir dinheiro "vivo" no momento que se apresenta a 
necessidade. O pagamento da fatura é feito no Banco no mês seguinte à compra.

- Microcrédito para mulheres. A linha de crédito específica para mulheres está conectada com sua participação no projeto Incubadora Feminina (descrito mais adiante) e procura atender a mulheres que se encontram em risco social.

- PalmaCasa. A linha de crédito PalmaCasa é dirigida para famílias que desejam fazer pequenas reformas em suas moradias que lhes permitam melhorar suas condições de produção. As compras de materiais devem ser feitas no próprio bairro. O Banco intermedia a compra pagando à vista para o vendedor, enquanto o cliente paga para o Banco em seis meses, com juros mensais de $1,5 \%$.

- Agricultura Urbana. Consiste em uma linha de crédito que tem por objetivo promover a produção familiar nos quintais das residências. Como o microcrédito para mulheres, esse também está ancorado em outro projeto do Banco, neste caso, a Incubadora de Agricultura Urbana. É disponibilizado um espaço na sede da ASMOCONP para cultivo de plantas medicinais, hortaliças, frutas, flores e criação de galinha caipira, além de contar com um minhocário e um tanque de compostagem de lixo, onde se aprendem as técnicas para logo serem replicadas. No caso em que as famílias decidam desenvolver alguma das práticas agrícolas nos seus quintais, terão acesso a um crédito com dois meses de carência e quinze meses para sua liquidação total. Nesse caso também se priorizam as mulheres, porém não exclusivamente.

A combinação de créditos para consumo e créditos para produção vem para suprir uma necessidade antes identificada por especialistas na área sobre as armadilhas que o crédito para consumo apresentaria para a população de baixa renda. A expansão deste tipo de créditos inclui as pessoas na sociedade de consumo, ampliando a demanda por bens e serviços, porém não gera empregos, pois a população empregada nas firmas demandantes de mão de obra não é a de 
baixa renda, que possui níveis muito baixos de escolarização (BARONE E SADER, 2008, p. 1264). Os créditos que gerariam emprego são os chamados créditos de produção, através dos quais se podem criar empreendimentos produtivos, utilizando as habilidades que os trabalhadores possuem e não exclusivamente a sua formação.

Em meados dos anos 2000, este tipo de crédito teve maior desenvolvimento no Brasil, principalmente a partir da criação do Programa Nacional de Microcrédito Produtivo Orientado, através da promulgação da Lei no 11.110, de 25 de abril de 2005, na orbita do MTE.

\subsubsection{Empreendimentos produtivos solidários}

Tendo como base a disponibilidade de oferecer créditos para produção, o Banco Palmas promove a criação de empreendimentos produtivos que venham a suprir alguma necessidade no bairro. Para isto, proporciona crédito e capacitação (oferecida pelo Palmatech ${ }^{82}$ ou outras organizações de capacitação) para grupos de empreendedores locais. "Os empreendimentos são independentes e interligados por instrumento e regras de solidariedade do sistema Palmas, (...) Utilizam a logomarca e as estruturas do Banco" (NETO II E MAGALHÃES, 2008, p. 52).

Buscando promover os valores de solidariedade e como forma de reduzir gastos operacionais, os projetos funcionam na sede da ASMOCONP, porém cada unidade produtiva é responsável pela sua administração.

Atualmente, funcionam cinco empreendimentos:

- Palmafashion. Trata-se de um grupo produtivo de costura do vestuário envolvendo mulheres da comunidade.

- Palmart. Pequeno grupo produtivo de mulheres que desenvolvem técnicas de artesanato para produção e venda.

- Palmalimpe. Consiste em um pequeno empreendimento para a produção de material de limpeza doméstica. Foi criada em dezembro de 2001 por um grupo de jovens do bairro e funciona sob o modelo de autogestão.

\footnotetext{
82 Escola Comunitária de Sócio-economia Solidária do Banco Palmas.
} 
- Palmanatus. Criado no ano de 2005 trabalha com sabonetes artesanais e fitoterápicos.

- Palmatur. É o mais recente empreendimento do Banco Palmas e consiste em uma empresa de turismo comunitário urbano, que surgiu a partir da incubadora feminina do Banco. Participam 20 mulheres do Conjunto Palmeira e adjacências, as quais se iniciam no caminho de reintegração no mercado de trabalho.

A promoção destes empreendimentos tem se constituído em fonte de renda para pessoas da comunidade, permitindo a produção e reprodução da força de trabalho que, embora no setor informal, movimenta a economia local.

\subsubsection{Microsseguro Palmas}

Em parceria com a CAMED Corretora de Seguros e a Zurich Seguros, empresa suíça com presença em 170 países, o Banco Palmas criou, em setembro de 2010, o Microsseguro Palmas. Consiste em um seguro completo, que garante proteção financeira aos seus contratantes, oferecendo cobertura de vida, funeral e plano de capitalização. De acordo com o coordenador geral do Banco Palmas, "Trata-se de um serviço financeiro que foca no fortalecimento das poupanças locais, oxigenando as redes locais de economia solidária" ${ }^{\text {"33 }}$. A pretensão é que a iniciativa seja implantada em toda a Rede Brasileira de Bancos Comunitários.

Cada contratante paga $\mathrm{R} \$ 27,30$ ao ano e procura diminuir os riscos produzidos pelos efeitos de situações inesperadas, como as mencionadas acima. Além disto, os assegurados participam de um sorteio mensal de $R \$ 5.000$. Importante destacar que os corretores de seguro são pessoas da própria comunidade, selecionadas e treinadas pelo Instituto Palmas. No ano de 2011, foram vendidos 2.211 microsseguros.

\footnotetext{
${ }^{83}$ Entrevista realizada pelo jornal O Estado com o Sr. Joaquim de Melo Neto II, idealizador e coordenador geral do Banco Palmas, no dia 20 de outubro de 2010. Disponível em: www.oestadoce.com.br/?acao=noticias\&subacao=ler_noticia\&cadernolD=8\&noticialD=35816 Acesso em março de 2011.
} 


\subsection{4 . Projetos sociais}

O Banco Palmas também elabora projetos sociais que procuram melhorar a qualidade de vida dos moradores da região, descritos brevemente a seguir:

Academia de Moda Periferia. É um espaço de formação e produção na área de moda destinado a mulheres e jovens da periferia de Fortaleza e Região Metropolitana, que busca melhorar a qualidade técnica e profissional de mulheres e jovens, promovendo a inclusão social desses no mundo do trabalho, baseado nos princípios da economia solidária.

- Bairro Escola de Trabalho. Trata-se de um projeto de capacitação profissional e geração de trabalho e renda dirigidos a jovens de 16 a 24 anos. Os empreendimentos do bairro, tais como comércios, indústrias e serviços capacitam e empregam os jovens da comunidade.

- Incubadora Feminina. Consiste em um projeto de geração de emprego e renda, exclusivamente para mulheres em situação de risco. O principal objetivo é proporcionar-Ihes a reinserção social e econômica, aumentando a autoestima, a capacidade de trabalho e o exercício da cidadania (NETO II, 2008). Aproveitando a estrutura da ASMOCONP, são realizadas oficinas, cursos profissionalizantes, ateliê de produção e um laboratório de agricultura urbana.

- Bate-palmas. Trata-se de uma companhia de música da qual participam jovens da comunidade, que inclui um estúdio de música, uma banda e uma oficina para criação de instrumentos musicais. Realiza atuações dentro e fora do bairro.

- Palmatech. Escola Comunitária de Socioeoconomia Solidária que oferece oficinas e cursos abordando os temas: gestão de empresas solidárias, criação de redes e instrumentos de Economia Solidária. As capacitações são dirigidas a produtores, consumidores, técnicos do poder público e OSC. Tem como valor central o controle da sociedade sobre a economia e o mercado como 
espaço de cooperação, colaboração e satisfação das necessidades humanas. (NETO II; MAGALHÃES, 2008)

- Escola Popular Cooperativa Palmas. Cursos de seis meses dirigidos aos jovens do Conjunto Palmeiras, providenciando preparação para o vestibular, assim como promoção do empreendedorismo e sensibilização para a participação em atividades comunitárias e de proteção ambiental.

Por ser constituída como uma organização da sociedade civil, para a efetivação destes projetos, realiza parcerias com os diversos setores, tais como governo, empresas privadas, organizações internacionais e outras OSC.

\subsection{Pagar com outra moeda.}

A moeda social surge na economia como meio de efetivar e contribuir com o desenvolvimento de experiências alternativas e solidárias de troca, entendidas como iniciativas que "buscan por medio del intercambio de bienes y servicios subsumidos a determinadas normas y valores, satisfacer una pluralidad de necesidades [...] de participación, de gestión con otros, etc." 84 (GUERRA, 2003, p. 42).

As trocas, em suas primeiras versões, são uma prática recorrente na América Latina que remonta séculos em formato de tokens, vales, entre outros instrumentos que mediaram às relações de trabalho.

Los economatos de la empresa [pulpería], que tenían especial mala fama en México y en la zona del nitrato en Chile, provocaban especial enojo. Las empresas utilizaban estos economatos como instrumento complementario para ejercer control por medio de las deudas y, también, para reducir más sus costes. Pagando con vales que sólo podían utilizarse en estos establecimientos, que con frecuencia cobraban precios exorbitantes, lo que en realidad hacían los propietarios era rebajar los salarios de los trabajadores e incrementar sus propios beneficios ${ }^{85}$ (HALL E SPALDINGD 1991, p. 290).

\footnotetext{
${ }^{84}$ Tradução livre da pesquisadora - Buscam por meio do intercâmbio de bens e serviços subsumidos a determinadas normas e valores, satisfazer a uma pluralidade de necessidades [...] de participação, de gestão com outros, etc.

${ }^{85}$ Tradução livre da pesquisadora - Os economatos da empresa [pulpería], que tinham especial má fama no México e na região do nitrato, no Chile, provocavam especial rejeição. As empresas utilizavam estes economatos como instrumento complementar para exercer controle por meio das dívidas e também para reduzir mais seus custos. Pagando com vales que somente poderiam ser utilizados em estabelecimentos, que com frequência cobravam preços exorbitantes, o que na verdade faziam os proprietários era diminuir os salários dos trabalhadores e incrementar seus próprios benefícios.
} 
Já no fim do século $X X$, o formato das trocas muda significativamente, legitimando a criação e difusão dos "clubes de troca" que promoveriam valores de autogestão, autonomia e o intercâmbio de bens e serviços através de relações reciprocas de solidariedade.

$\mathrm{Na}$ América Latina, os primeiros clubes de troca nasceram na Argentina, no ano de 1995, difundindo-se no Uruguai, Brasil, Equador, Peru, Colômbia, Chile, Bolívia e América Central, em 1998. Porém, seu momento de auge foi a partir dos anos 2000 e, principalmente, desde o ano 2003, como instrumentos para paliar as consequências da crise que afetava os países, principalmente os do Cone Sul.

Nessa época também aparecem as moedas sociais, complementando o sistema caracterizando-se por: "Nacer al interior de grupos sociales organizados con el fin de intercambiar bienes y servicios sobre la base del trueque y de valores sociales alternativos a los de la competitividad individualista, mas propia del homo oeconomicus, que genera el mercado de intercambio"86 (GUERRA, 2003, p. 37).

De acordo com Menezes e Crocco (2009), moedas sociais ou circulantes locais são:

\begin{abstract}
Instrumentos utilizados como meio de conta e de pagamento e que convivem paralelamente às moedas nacionais, mas sem concorrer com estas, apenas as complementando. Sua validade é limitada, a priori, seja por um certo conjunto de bens ou serviços ou pessoas, seja um espaço específico ou fixada em um horizonte temporal dado (...) os aspectos mais importantes dessa moeda são: (i) iniciam-se no terceiro setor, isto é fora do Estado e do mercado capitalista; (ii) têm restrição do uso no espaço e (iii) inexiste a incidência de juros (MENEZES E CROCCO, 2009, p. 378-381).
\end{abstract}

Neste sentido, trata-se de um instrumento que promove um nível de relação mais estreito entre consumidores e produtores em uma região determinada, fazendo com que o dinheiro circule na comunidade, suprindo a sua escassez.

No ano de 2000, acompanhando o movimento que se podia visualizar na América Latina, o Banco Palmas cria seu próprio clube de troca: o Palmares. A falta de variedade na oferta de produtos e a divergência entre as expectativas de quem pretendia trocar e os produtos a serem efetivamente intercambiados fez com que a iniciativa ficasse pouco atraente e se encerrasse ao longo de dois anos.

\footnotetext{
86 Tradução livre da pesquisadora - Nascer no interior de grupos sociais organizados com o fim de trocar bens e serviços sobre a base da permuta e de valores sociais alternativos à competitividade individualista, mais própria do homo oeconomicus, que gera o mercado de troca.
} 
A cada dia ficava mais claro que o nosso clube de trocas não apontava qualquer perspectiva de desenvolvimento econômico capaz de fazer com que o poder aquisitivo das famílias fosse se fortalecendo na perspectiva de, gradativamente, melhorar a qualidade de vida das mesmas. [...] Estando dentro de um bolsão de pobreza, a simples troca de produtos e serviços entre os próprios pobres jamais seria capaz de gerar e atrair novos recursos necessários para fazer a comunidade crescer e se desenvolver (NETO II E MAGALHÃES, 2005, p. 15).

Estas constatações abriram caminho para o que seria denominado posteriormente como o Sistema de Moeda Social Circulante no Conjunto Palmeira.

Em 2002, o Banco Palmas assume mais um desafio para o seu sistema de finanças solidárias e desenvolvimento local: a passagem de um clube de troca para um sistema de moeda social local circulante. Trata-se de uma moeda complementar ao Real, criada pelo Banco Palmas, que pretende fazer com que o "dinheiro" circule na própria comunidade, e desta forma, amplia-se o poder de comercialização local, aumenta-se a riqueza que circula na comunidade e também gera trabalho e renda (NETO II E MAGALHÃES, 2005).

Segundo os mesmos autores, as principais caraterísticas da moeda social Palmas são:

- Lastro em Real. Para cada moeda emitida, existe no banco comunitário um correspondente em Real.

- Possuem componentes de segurança para evitar falsificação.

- Circulação livre no comércio local e, geralmente, quem compra com a moeda social recebe um desconto promovido pelos comerciantes e produtores para incentivar o uso da moeda no bairro;

- Qualquer produtor/comerciante cadastrado no Banco Comunitário pode trocar moeda social por reais, caso necessite fazer uma compra ou pagamento fora do bairro.

- Ao se relacionar diretamente com o sistema de créditos do Banco Palmas, os tomadores de créditos podem escolher este tipo de moeda para quitar seus débitos e a quem adquirir um empréstimo em moeda social não Ihes será cobrada nenhuma taxa de juros.

- Os Palmas podem ser trocados por Reais, nos casos em que se justifique que esse dinheiro será utilizado para equipar e/ou inovar no empreendimento que é desenvolvido na própria comunidade. 
- O Banco Palmas tem uma parceria com o Banco Popular do Brasil, ${ }^{87}$ que permite o pagamento de contas, títulos bancários, duplicatas e outros serviços financeiros com Palmas no caixa do BCD para a população da comunidade.

Pode se observar na pesquisa que há uma grande tendência a ampliar os lugares que aceitam e os que providenciam a moeda social. Isto é, constantemente, trabalha-se para que cada vez sejam mais os produtores locais (comerciantes de todo tipo) que aceitem o pagamento em Palmas, e por outro lado, há evidentes esforços para fazer com que outros agentes se integrem neste circuito, como expressado por Neto II e Magalhães, na seguinte passagem:

É preciso sermos criativos e tentarmos convencer a todas as instituições e empresas que atuam no bairro a realizarem parte do pagamento de salários, bolsas, ajudas de custo, prestação de serviços e outras contribuições em circulante palmas (NETO II, 2005, p. 46).

Como acontece no Banco Palmas, todos os BDCs que constituem a Rede de Bancos Comunitários do Instituto Palmas contam com a sua moeda local, criada sempre em função de características locais que, segundo os idealizadores do Banco Palmas, promovem o resgate da identidade da comunidade.

\subsection{A experiência que transcendeu o Conjunto Palmeira: o Instituto Palmas}

Após cinco anos de existência do Banco Palmas e já com certa visibilidade por ter se constituído em uma experiência inovadora no país e na região, outras instituições manifestaram a intenção de criar novos Bancos Comunitários em outros bairros e cidades.

Para isso, em 2003, constituiu-se o Instituto Palmas que é uma organização da sociedade civil, sem fins lucrativos, cujo objetivo é fazer a gestão do conhecimento e a difusão das práticas de economia solidária do Banco Palmas.

\footnotetext{
${ }^{87}$ O Banco Popular do Brasil é uma instituição financeira brasileira, subsidiária integral do Banco do Brasil, fundada em 2003, destinada exclusivamente a atender pessoas de baixa renda. É importante destacar que o Banco Popular do Brasil foi incorporado pelo Banco do Brasil, em 2008. Em 2009, a bandeira Banco Popular do Brasil foi substituída pela bandeira Banco Mais, do Banco do Brasil.
} 
Segundo Neto II, "o foco da ação está voltado para implantação de sistemas econômicos alternativos na perspectivada da inclusão social".

No ano de 2005, o Instituto Palmas assinou um convênio com a SENAES para apoiar tecnicamente a criação de mais BCD e fazer a transferência de tecnologia.

Em 2006, realizou uma parceria com o Banco Popular do Brasil (BPB) ${ }^{88}$ para fazer a difusão da sua metodologia. Os recursos eram oriundos do PNMPO ${ }^{89}$. Também no ano de 2006, a Petrobras apoiou a criação de mais doze BCD (Neto II e Magalhães, 2006).

Partindo desta experiência para a criação de novos BDC, o Instituto Palmas organizou e gerencia um Fundo de Crédito que repassa um recurso inicial de $R \$$ 30.000,00 (trinta mil reais) e facilita a implantação dos correspondentes bancários (da Caixa Econômica Federal ou do BB) em cada novo banco comunitário criado.

Atualmente, existem 55 BCDs localizados em 12 dos 27 estados brasileiros, como mostra o mapa abaixo. A maioria deles se concentra no Ceará, sendo que São Paulo, Bahia e Espírito Santo são os Estados que Ihe seguem em quantidade.

\footnotetext{
${ }^{88}$ O Banco Popular do Brasil, subsidiário integral do Banco do Brasil surge em 2003, visando a inclusão bancária da população de baixa renda.

${ }^{89}$ O Programa Nacional de Microcrédito Produtivo Orientado - PNMPO foi instituído pela Lei 11.110, de 25 de abril de 2005, e tem os seguintes objetivos gerais: incentivar a geração de trabalho e renda entre os microempreendedores populares; disponibilizar recursos para o microcrédito produtivo orientado; oferecer apoio técnico às instituições de microcrédito produtivo orientado, com vistas no fortalecimento institucional destas para a prestação de serviços aos empreendedores populares. No âmbito do PNMPO, são considerados microempreendedores populares as pessoas físicas e jurídicas empreendedoras de atividades produtivas de pequeno porte, com renda bruta anual de até $\mathrm{R} \$ 120$ mil. Informação obtida no site oficial do Ministério de Trabalho e Emprego: www.mte.gov.br
} 


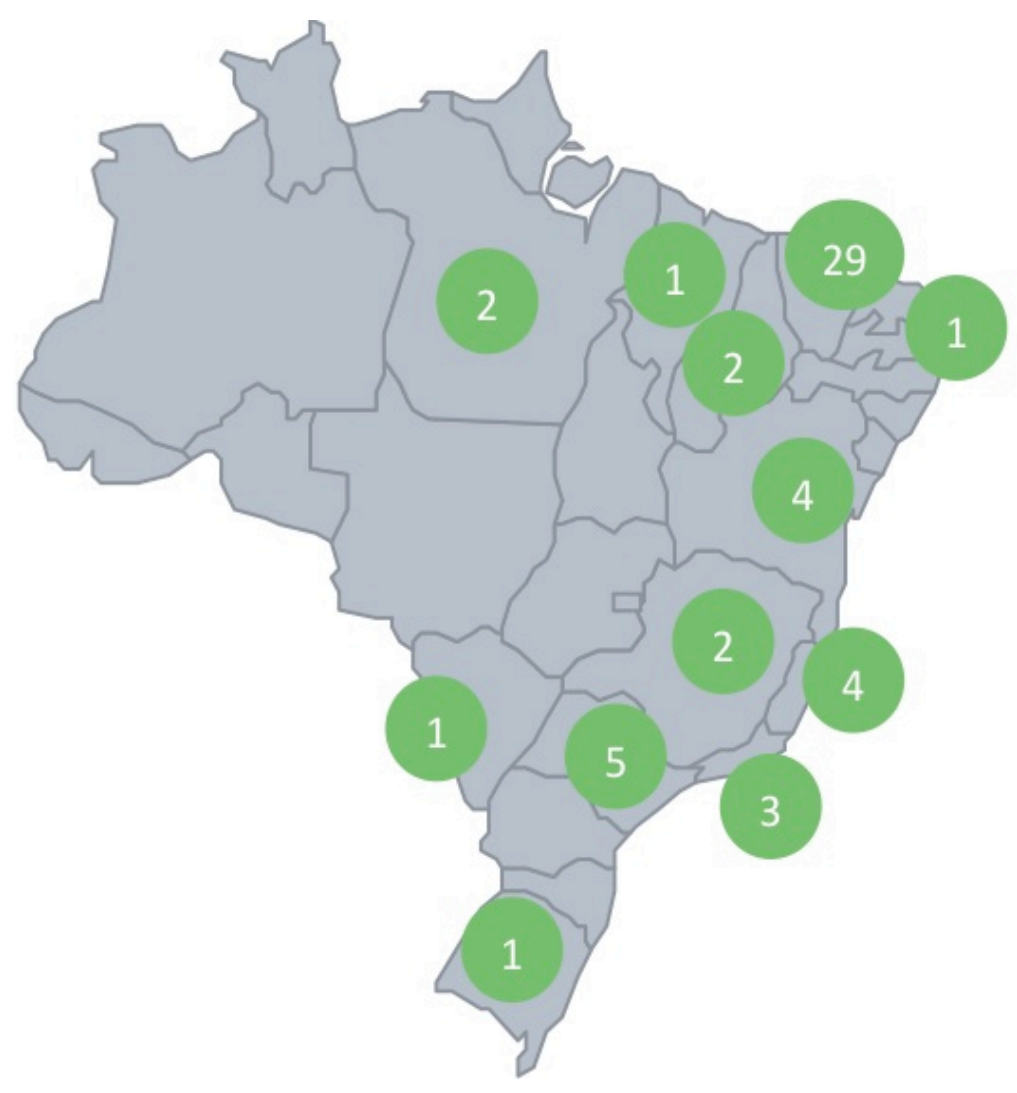

Figura 1 - Mapa: Rede de Bancos Comunitários. (Elaboração própria)

Para criar um BCD, precisa, segundo seu idealizador, de três requisitos primordiais: ter demanda da comunidade, um local com estrutura adequada que inclui um espaço físico com telefone e internet e um ator local que desenvolverá a iniciativa. Em muitos casos, quem proporciona a infraestrutura são as Prefeituras.

O Instituto opera também a Rede Brasileira de Bancos Comunitários, na qual se articulam todos os BCDs do Brasil. Cadastram-se na Rede todos os Bancos que, após um processo de formação, recebem o selo de certificação da Rede de Bancos Comunitários. Todos os BCDs têm obrigação de "prestar contas" de suas atividades anualmente no Encontro Nacional da Rede de Bancos Comunitários.

Para finalizar, é importante fazer algumas considerações. O conjunto destas atividades, programas e projetos realizados pelo Banco Palmas, trazem, sem sombra de dúvida, mudanças nas condições de vida da população local que se beneficia com eles e atinge patamares de bem-estar antes não vivenciados. No entanto, com base nestes elementos, interessa observar o movimento quase contraditório da proposta, incluída no que vem sendo chamado de economia 
solidária, quando coloca "os empreendimentos ditos solidários na condição de funcionalidade ao sistema orgânico do capital” (BENINI, 2011, p. 76).

Havendo um estímulo constante ao consumo, muitas vezes estas propostas atuam como mediadoras de relações capitalistas de produção, sem conseguir transcendê-las. Além disso, busca-se emplacar a autogestão no capitalismo, sendo que, como já foi observado no decorrer deste trabalho, não há possibilidade destes dois dividirem o mesmo espaço. A autogestão é uma forma de organização da sociedade, não um modo de produção, e enquanto isto não for compreendido, não é possível visualizar formas não alienantes de produção e reprodução da força de trabalho.

\section{NO EQUADOR: A CEPESIU E AS SOCIEDADES POPULARES DE INVERSIÓN}

O CEPESIU é uma organização civil sem fins lucrativos fundada em 1983 na cidade de Guayaquil, no Equador, com o objetivo de oferecer apoio às pessoas que se encontravam desenvolvendo projetos produtivos de maneira informal nas regiões urbanas e rurais do país.

A missão da organização é, segundo seus fundadores, a de

Impulsar el desarrollo sostenible -con equidad- a través de la promoción e implementación de programas y proyectos de apoyo al desarrollo de las unidades económicas de pequeña escala, en los ámbitos urbano y rural en el Ecuador ${ }^{90}$ (CEPESIU, 2010).

No começo, dedicava-se à pesquisa do setor informal urbano nas cidades de Guayaquil e Quito, mas, posteriormente, começou a desenvolver programas mais amplos que incluíam serviços financeiros e serviços empresariais não financeiros. Os primeiros buscavam fortalecer a autogestão dos microempreendedores individuais, e os segundos focavam no apoio ao desenvolvimento tecnológico, à comercialização, capacitação, assistência técnica, articulação e fortalecimento de atores e iniciativas locais.

Os programas são dirigidos a pessoas de baixa renda (renda menor do que o valor de uma cesta básica) que possuem uma família com cinco ou mais membros,

\footnotetext{
${ }^{90}$ Tradução livre da pesquisadora - Promover o desenvolvimento sustentável com equidade, por meio da promoção e implementação de programas e projetos de apoio ao desenvolvimento das unidades econômicas de pequena escala, em âmbitos urbanos e rurais do Equador.
} 
atendendo ao redor de 8.500 microempreendedores, dos quais 65 \% são mulheres chefes de família.

Para atingir estes resultados, o CEPESIU (2010) estabelece cinco objetivos estratégicos:

(1) Procurar a melhoria das economias locais através de serviços integrais, como o fortalecimento dos atores locais, disseminação de instrumentais e ferramentas para o desenvolvimento econômico.

(2) Promover o acesso das unidades econômicas de pequena escala às microfinanças e expandir a cobertura e qualidade do serviço de microcrédito.

(3) Procurar o desenvolvimento das Unidades Econômicas de Pequena Escala ${ }^{91}$ (UEPE), por meio dos serviços de desenvolvimento empresarial e de fortalecimento de sua organização e institucionalidade.

(4) Fortalecer a institucionalidade de apoio às UEPE e fazer a gestão do conhecimento sobre as UEPE e o Programa de Fomento do Desenvolvimento Econômico Local ${ }^{92}$ (DEL).

(5) Fazer com que o CEPESIU se desenvolva institucionalmente de forma constante.

$A$ atuação da CEPESIU é ampla e variada. Ela atua nas províncias ${ }^{93}$ de Esmeraldas, Guayas, Santa Elena, Pichincha, Santo Domingo de los Tsáchilas, Tungurahua, Chimborazo, Bolívar e Napo, ocupando três das quatro regiões em que se divide o Equador, como ilustra o mapa abaixo.

\footnotetext{
${ }^{91}$ Nome original: Unidades Económicas de Pequeña Escala - UEPE

${ }^{92}$ Nome original: Programa de Fomento del Desarrollo Económico Local - DEL

${ }^{93}$ Província é a denominação utilizada no Equador para identificar a divisão territorial do Estado.
} 


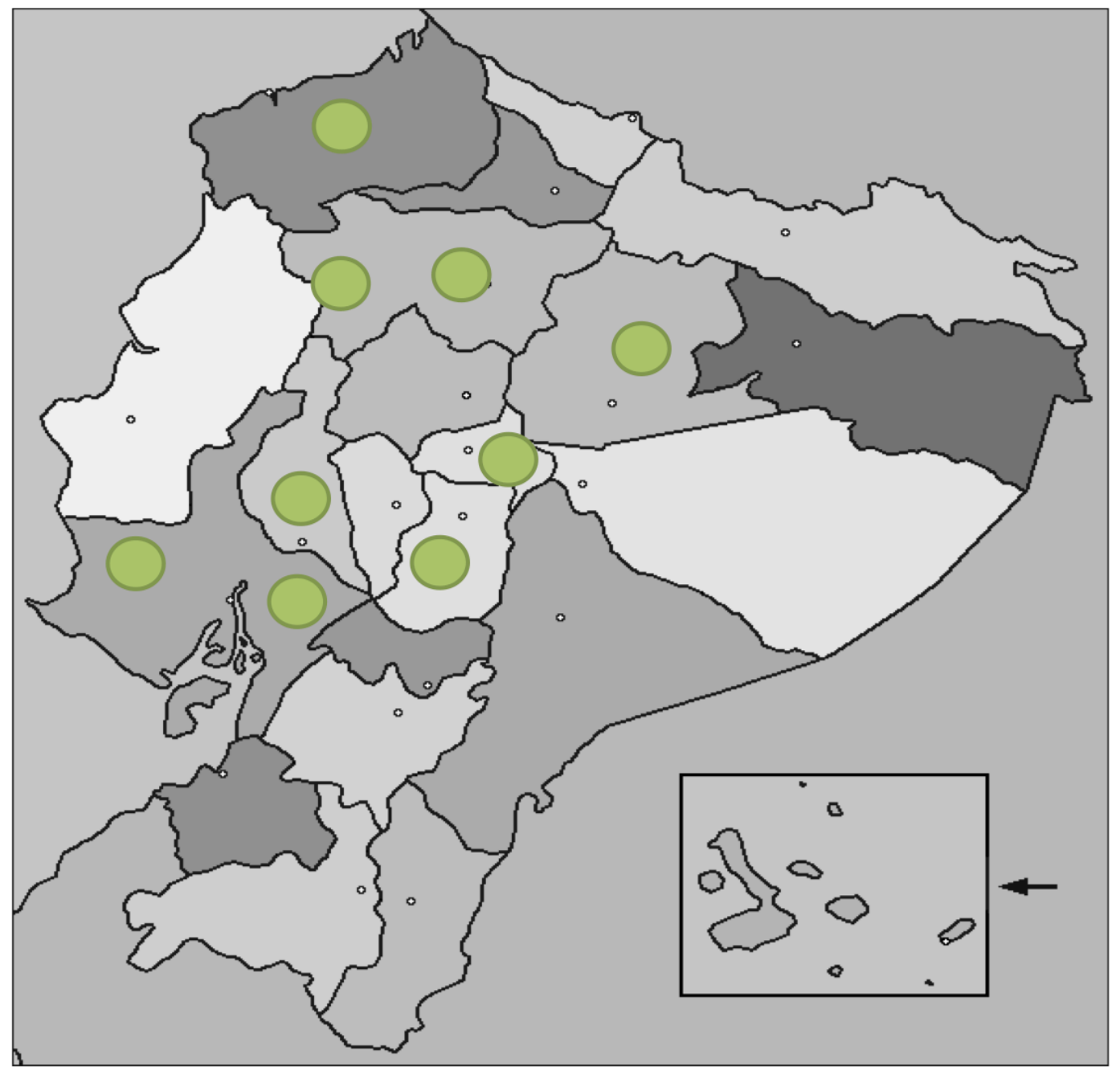

Figura 2 - Mapa: Rede de SPI no Equador. (Elaboração própria)

No decorrer de sua atuação, a organização desenvolveu diversos programas de finanças solidárias. Para efeito desta pesquisa, serão destacadas asas SPIs, pela sua semelhança com os Bancos Comunitários de Desenvolvimento que atuam na América Latina. No entanto, a seguir, serão mencionados os principais programas desenvolvidos pelo CEPESIU e seus traços mais característicos.

\subsection{Principais programas desenvolvidos pelo CEPESIU}

Assim como o Banco Palmas, o CEPESIU contém uma carteira de produtos financeiros que atende diferentes necessidades da população de baixa renda. Entre eles se destacam: o Programa de Fomento do Desenvolvimento Econômico Local, Serviços de Microfinanças, Serviços de Desenvolvimento Empresarial e serviços de 
apoio para a reinserção econômica e social de emigrantes e para a melhoria habitacional popular, todos citados a seguir.

A) Programa de Fomento do Desenvolvimento Econômico Local

Consiste em um programa para dinamizar as médias e pequenas economias. O objetivo central é:

Contribuir a la reducción de la pobreza, a través de varios componentes que inciden en el mejoramiento de las actividades económicas de pequeña escala, en las cadenas productivas conformadas por micro y pequeñas unidades económicas y en la producción y capitalización de los excedentes en el propio espacio geográfico ${ }^{94}$ (CEPESIU, 2010, p. 32).

Buscando aperfeiçoar as capacidades locais para o desenvolvimento econômico, utiliza três estratégias principais, resumidas a seguir: (1) Fortalecimento da institucionalidade local - consiste na articulação de atores locais para a elaboração de um diagnóstico e um plano de desenvolvimento integral da economia local, além de oferecer capacitação e assistência técnica às equipes regionais. (2) Melhoramento das atividades econômicas locais - trata-se de fortalecer as cadeias produtivas e promover vínculos entre elas, que possibilitem a maior dinamização do mercado local. (3) Implementação de sistemas e instrumentos de suporte buscando reter e capitalizar os excedentes para a sustentabilidade da economia local, o CEPESIU promove a inserção dos microempreendedores em institutos de ensino em áreas afins ao empreendimento, e facilita o acesso a redes de conectividade e informação para aprimorar a inserção no mercado.

B) Serviços de Microfinanças

O Serviço de créditos é, como visto para o caso brasileiro, um eixo fundamental no desenvolvimento destes projetos. O CEPESIU oferece este produto, desde 1987, para a população que não tem acesso a créditos na banca convencional.

Trabalha-se com quatro tipos de microcrédito:

\footnotetext{
94 Tradução livre da pesquisadora - Contribuir para a redução da pobreza, através de vários componentes que incidem no melhoramento das atividades econômicas de pequena escala, nas cadeias produtivas formadas por micro e pequenas economias e na produção e capitalização dos excedentes no próprio espaço geográfico.
} 
- Programa de Crédito Direto (PCD): Requer um acordo entre uma organização microempresarial formalmente constituída e o CEPESIU. Para ter acesso, é necessário constituir um comitê de crédito, um fundo de garantia e a concessão e registro dos créditos individuais com garantia de grupos solidários.

- Programa de Crédito Autoadministrado (PCA): Este tipo de crédito é concedido a uma organização de base comunitária a fim de que esta realize uma intermediação financeira efetiva com assessoria do CEPESIU.

- Programa de Grupos Solidários (PGS): Créditos individuais com garantia de grupos solidários, de três a cinco membros que depositam um fundo de garantia, liberado só quando todos os membros cancelaram os empréstimos.

- Programa de Crédito Individual (PCI): Consiste em uma linha de créditos dirigida a clientes que requerem quantias maiores, e neste caso, se requerem garantias pessoais e prendarias.

Antes de continuar, é importante destacar que o Equador tem avançado no que diz respeito à oferta de serviços microfinanceiros, condicente com uma política de desenvolvimento baseada nos princípios do bom-viver, como visto no capítulo III deste trabalho. Isto é significativamente importante e se apresenta como uma possibilidade de inclusão financeira e social para os setores mais empobrecidos, é necessário ser cuidadoso na hora do otimismo indiscriminado.

Além de possibilidades de progresso econômico, estas alternativas podem trazer o endividamento massivo da população, se apresentando como a solução para os problemas da pobreza, responsabilizando, novamente, os indivíduos pela sua própria sorte (ou falta dela).

Segundo Gómez Gil,

El argumento de que contra la pobreza no hay nada mejor que créditos trata de romper el compromiso político y moral de la AOD, pretendiendo encubrir las verdaderas causas que están en la base de la pobreza y el subdesarrollo en el mundo y convirtiendo a los pobres en responsables últimos de su situación. Al mismo tiempo, sirve para anular las políticas de cooperación internacional, transformándolas en políticas de bancarización y convirtiendo la pobreza inmensa en deuda eterna, ya que a mayor número de pobres, mayor número de créditos concedidos, con lo que aseguramos una clientela prácticamente ilimitada que permita 
engrasar un sistema capitalista que habrá entrado así hasta en los países más empobrecidos ${ }^{95}$ (GÓMEZ GIL, 2011, p. 16).

Assim, é importante também colocar estes elementos na discussão, quando se trata de analisar os efeitos não sempre visíveis destas estratégias, para que não se convertam no fim, em meras estratégias de colaboração para a expansão do capitalismo global.

C) Serviços de Desenvolvimento Empresarial

Buscando contribuir com o desenvolvimento dos empreendimentos que foram postos em funcionamento, o CEPESIU desenvolve uma carteira de serviços de desenvolvimento empresarial que consistem em:

- Assistência técnica e assessoria financeira. O programa tem o objetivo de melhorar as capacidades dos microempreendedores para administrar e melhorar seus negócios, com assessorias in loco, prévias à concessão do crédito.

- CESPROE. O Centro de Serviços Produtivos para Marcenaria ${ }^{96}$ é um serviço de desenvolvimento para a indústria de mobília, dirigido a microempresários na área de marcenaria especializada. Consiste em uma planta semi-industrial, que facilita a inserção dos marceneiros no mercado e implica na melhoria da produção por meio de utilização de novas tecnologias e aprimoramento dos seus processos produtivos.

- Assistência técnica para novos empreendimentos. Dirigido a empreendedores que desejem implementar novas atividades, individual ou grupalmente. A atividade prevê a assessoria para a escolha do negócio, assistência técnica para a realização do plano de negócios, análise de mercado, e assessoria para a implementação da iniciativa.

A partir da identificação destes serviços, é possível constatar que os mesmos acompanham a tendência que aparece nos anos 90 e se perpetua no século XXI,

\footnotetext{
95 Tradução livre da pesquisadora - O argumento de que contra a pobreza no há nada melhor que créditos, trata de quebrar o compromisso político e moral da AOD, pretendendo encobrir as verdadeiras causas que estão na base da pobreza e o subdesenvolvimento no mundo e convertendo aos pobres em responsáveis últimos de sua situação. Ao mesmo tempo, serve para anular as políticas de cooperação internacional, transformando-as em políticas de bancarização e convertendo a pobreza imensa em dívida eterna, já que a maior número de pobres, maior número de créditos concedidos, com o asseguramos uma clientela praticamente ilimitada que permita engraçar um sistema capitalista que haverá entrado assim até aos países mais empobrecidos.

${ }^{96}$ Nome original: CESPROE - Centro de Servicios Productivos para la Ebanistería
} 
quanto à profissionalização dos setores de baixa renda. As instituições financeiras incluíram nas suas atividades programas de formação e capacitação que promovem o ensino de técnicas e ferramentas para fomentar 0 "empreendedorismo". Assim, propõem assessoria, capacitação e a promessa de um empreendimento de sucesso, dando ao setor informal maiores possibilidades de crescimento, caso as indicações sejam adotadas. No entanto, o que garantem, em primeira e última instancia, são as condições para a reprodução do capital e é neste aspecto que radica uma das principais críticas feitas à economia solidária, a partir da pesquisa das experiências práticas expostas neste trabalho.

D) Apoio para a reinserção econômica e social de emigrantes

Segundo o Instituto Nacional de Estadísticas y Censo, em proporção à sua população, o Equador é o país sul-americano de maior emigração, sendo que o 8 \% dos habitantes moram no exterior. A escassa possibilidade de mobilidade social, a instabilidade política e por fim, a grande crise que o país enfrentou entre 1982 e 1991, e com isto o fim dos programas e políticas sociais, fizeram com que emigrar se tornasse a melhor saída para muitos dos equatorianos. O jornalista e escritor peruano, González Manrique, opina sobre o caso da imigração equatoriana:

La emigración se ha convertido en una extensión radical de la emigración interna a las ciudades, pero que no depende del manejo de las políticas económicas nacionales: las remesas no son controladas por el gobierno -como el petróleo- ni sus receptores se ven forzados a esperar el goteo de los auges de la exportación del plátano o el camarón ${ }^{97}$ (GONZÁLEZ MANRIQUE, 2006).

Assim, pessoas de baixa renda contraiam dívidas e buscavam o futuro nos países europeus e nos Estados Unidos, que mesmo oferecendo trabalhos precários, Ihes permitiam se sustentar e enviar dinheiro para as suas famílias. As chamadas "remessas" são, junto ao petróleo, os dois principais componentes do PIB do país.

No ano de 2007 e de 2008, já no período do atual Presidente Rafael Correa, o CEPESIU em parceria com a Coordenação e Iniciativas para Refugiados e Estrangeiros da Bélgica (CIRE) e a Hebrean Inmigrant Aid Society (HIAS) do

\footnotetext{
${ }^{97}$ Tradução livre da pesquisadora - A emigração se há convertido em uma extensão radical da emigração interna às cidades, mas que não depende do manejo das políticas econômicas nacionais: as remessas não são controladas pelo governo - como o petróleo- nem seus receptores se vêm forçados a esperar o goteio dos auges da exportação do plátano ou do camarão.
} 
Equador; iniciam o projeto "Assistência para a Reinserção de equatorianos que retornam voluntariamente desde a Bélgica" 98 , visando a reinserção dos emigrantes equatorianos.

O projeto consiste em fornecer informações, oferecer apoio psicossocial e familiar e dar assessoria e apoio para a inserção empresarial, por meio de pequenos empreendimentos a serem criados, ou apoiando os já existentes nas famílias que ficaram no Equador.

Pode-se observar que os projetos de inserção produtiva são vistos como uma forte alternativa ao desemprego e uma oportunidade para redesenhar as estratégias do Estado equatoriano para o desenvolvimento do país.

E) Apoio para a melhoria habitacional popular

Em parceria com os governos locais e com o Consórcio ETIMOS da Itália, destinam-se créditos a microempreendedores de baixa renda, sem salário fixo, das áreas rurais para construção ou melhorias habitacionais, para uso da família ou para uso produtivo. Segundo seus idealizadores:

Este programa tiene una especial preocupación por consolidar políticas públicas incluyentes, en términos de género, al prever -con singular atención- el otorgamiento de microcréditos a mujeres, jefas de familia, población mayormente afectada por la falta de vivienda, quienes lideran cotidianas iniciativas y aportan todos sus ingresos a la economía familiar de subsistencia ${ }^{99}$ (CEPESIU, 2010, p. 75).

Este tipo de crédito é mais um exemplo de cooperação e intervenção de organizações internacionais no desenvolvimento destas estratégias. Enquanto isso, não existe no Equador uma política de Estado que garanta o acesso à moradia, embora esteja instituído na sua Constituição. Assim, mais uma vez, os créditos e as dívidas contraídas pelos indivíduos cumprem um papel fundamental na garantia de direitos sociais.

\footnotetext{
${ }^{98}$ Nome original do projeto: Assistência para la Reinserción de ecuatorianos que retornam voluntariamente desde Bélgica.

${ }^{99}$ Tradução livre da pesquisadora - Este programa tem uma preocupação especial por consolidar políticas públicas inclusivas em termos de gênero, ao prever - com singular atenção - o outorgamento de microcréditos a mulheres, chefes de família, população majoritariamente afetada pela falta de moradia, que lideram iniciativas cotidianas e aportam toda a sua renda à economia familiar de subsistência.
} 


\subsection{A gestão do CEPESIU}

O CEPESIU é financiado por fundos reembolsáveis da cooperação internacional. Os principais financiadores são: Consorcio ETIMOS, Oikocredit, Banco Interamericano de Desenvolvimento, Cresud, Alterfin, FOGAL, Envest Inc, Babylon; em nível nacional: Coodesarrollo, Cooperativa Jardín Azuayo, Fondos del Sistema Nacional de Microfinanzas Economía Solidária (do qual são operadores diretos). Além desta cooperação financeira, contam com cooperação técnica de especialistas ibero-americanos, incluindo Espanha, México, El Salvador, Nicarágua, Argentina e Uruguai com quem constituem a RAYAS ${ }^{100}$.

Segundo os seus criadores: o CEPESIU, desde seu início, se concebe como uma organização que articula esforços coletivos para impactar de forma transcendente no desenvolvimento do país e da América Latina. Para isso, busca não superpor ações, e sim estabelecer alianças estratégicas com organizações que tenham a mesma visão de desenvolvimento. Para eles, o desenvolvimento se entende como a conjunção da participação ativa e protagonista das organizações de base comunitária, os beneficiários dos programas, os governos locais, o setor acadêmico, as OSCs e as agências de cooperação (CEPESIU, 2010).

\subsection{As sociedades populares de inversión}

Inspirados no modelo de Bancos Comunitários de Desenvolvimento criado e disseminado pela Finca, organização descrita no capítulo III, em 1998, o CEPESIU criou as Sociedades Populares de Inversión, localizadas em grande parte do território equatoriano, definidas pelos fundadores como:

Organizaciones independientes y autónomas, de tipo empresarial, de carácter local y popular, propiedad de personas que -generalmentetienen actividades económicas de pequeña escala y que constituyen un capital mediante aportes patrimoniales individuales. Están dirigidas y controladas por los socios, su finalidad principal es brindar servicios financieros (inversión, crédito y ahorro) a sus integrantes, y también a otras personas no socias de los ámbitos geográficos (localidades, barrios, comunidades) donde operan ${ }^{101}$ (CEPESIU, 2010, p.40).

\footnotetext{
100 A Rede Rayas é uma rede iberoamericana para o fomento do desenvolvimento local transfronteiriço.

101 Tradução livre da pesquisadora- Organizações independentes e autônomas, do tipo empresarial, de caráter local e popular, propriedade de pessoas que - geralmente - desenvolvem atividades econômicas de pequena escala e constituem um capital por meio de aportes patrimoniais individuais. São dirigidas e controladas pelos
} 
Nesse sentido, trata-se de uma "estrategia de promoción de sistemas autogestionados de ahorro, crédito y capitalización local para la población de menores ingresos"102 (CEPESIU, 2010, p. 40).

Os créditos concedidos são para o desenvolvimento de atividades econômicas, capital de trabalho e também para necessidades familiares ou pessoais. O valor é, aproximadamente, de U\$S 200 e cada pessoa atendida tem recebido, em média, três créditos.

Mesmo tornando-se uma estratégia que gera resultados em curto prazo, as SPIs pretendem gerar bases sustentáveis para criar estratégias de crédito de longo prazo. Nesse sentido, os créditos são concedidos a pessoas que oferecem confiança, disposição para trabalhar e baixo risco de inadimplência. Ao ser um projeto que se realiza na comunidade, os vizinhos se tornam os maiores informantes sobre os comportamentos dos tomadores de crédito.

Segundo o CEPESIU:

El modelo implica que el grupo debe diseñar, constituir y manejar una organización específica e independiente para operar los servicios de ahorro, crédito y capitalización. Se trata de una institucionalidad con una clara definición de la propiedad y de los derechos y deberes de sus miembros sobre el capital y sobre la empresa $^{103}$ (CEPESIU, 2010, p. 41).

Estas iniciativas surgem a partir da concepção de que o progresso só será atingido se vier acompanhado de estratégias que possibilitem o desenvolvimento econômico local, o que implica no reconhecimento do território como eixo organizador da atividade econômica e o envolvimento dos agentes e atores locais como protagonistas do seu desenvolvimento (CEPESIU, 2009)

Segundo CEPESIU, o desenvolvimento econômico local significa:

El empoderamiento de las capacidades locales, que posibilita a los agentes locales intervenir sobre si mismos (operar su propio desarrollo) principalmente el desarrollo económico basado en la búsqueda de acumulación local, la que es posible promoviendo la

sócios, sua finalidade principal é fornecer serviços financeiros (investimento, crédito e poupança) aos seus integrantes e também a outras pessoas não sócias dos âmbitos geográficos (localidades, bairros, comunidades) onde operam.

102 Tradução livre da pesquisadora - Estratégia de promoção de sistemas autogeridos de poupança, crédito e capitalização local para a população de baixa renda.

${ }^{103} \mathrm{O}$ modelo implica que o grupo deve desenhar, constituir e dirigir uma organização específica e independente para operar os serviços de poupança, crédito e capitalização. Trata-se de uma institucionalidade com uma clara definição da propriedade e dos direitos e deveres de seus membros sobre o capital e sobre a empresa. 
integración del tejido productivo local, elemento organizador del quehacer es el territorio ${ }^{104}$ (CEPESIU, 2009, p. 6).

Para isto, as SPIs atuam como uma ferramenta de inclusão econômica e social entre pessoas que já desenvolvem algum tipo de atividade econômica de pequeno porte e que dividem um mesmo espaço geográfico, além de possuir vínculos entre eles. A intenção é que não sejam trabalhadores informais isolados, mas grupos autogeridos, que lhes dê a possibilidade de obter serviços de investimento para eles e para outras pessoas da localidade.

O grupo de microempreendedores, como são chamados pelo CEPESIU, passa a se constituir em uma empresa que operacionaliza serviços financeiros, bem próximo do que se entende por uma instituição financeira do tipo dos Bancos tradicionais.

Os sócios são os proprietários do Banco, e para formalizá-lo devem constituir um fundo que é composto por pequenos aportes individuais de cada integrante. É com este capital inicial que podem realizar os primeiros empréstimos. A qualidade de sócio-proprietário Ihes proporciona o direito de participar na tomada de decisões, e de participar das utilidades e do risco de perdas que possam ter e o direito de solicitar crédito, o qual muitas vezes é o principal motor para a integração dessas iniciativas.

O CEPESIU oferece assistência técnica e acompanhamento das iniciativas, porém cada SPI é responsável por estabelecer suas regras de funcionamento e pela organização interna, de forma tal que cada uma mantenha sua autonomia. Segundo o CEPESIU:

El grupo, en colectivo, establece sus propias reglas de participación (reglamentos), tanto de la empresa cuanto de los servicios financieros que la empresa les brinda. Cada grupo define la forma de organización interna con la que va a funcionar su SPI: las condiciones para el ingreso y salida de socios, el monto y condiciones de los aportes de capital, las condiciones y requisitos de los créditos y la forma de operar los servicios ${ }^{105}$ (CEPESIU, 2009, p. 14).

\footnotetext{
104 Tradução livre da pesquisadora - O empoderamento das capacidades locais, que possibilita aos agentes locais intervir sobre si mesmos (operar seu próprio desenvolvimento) principalmente o desenvolvimento econômico baseado na procura de acumulação local, a qual é possível promovendo a integração do tecido produtivo local, elemento organizador do afazer no território.

${ }^{105}$ Tradução livre da pesquisadora - O grupo, coletivamente, estabelece suas próprias regras de participação (regulamentos), tanto da empresa quanto dos serviços financeiros que a empresa lhes oferece. Cada grupo define a forma de organização interna sob a qual vai funcionar a SPI: as condições para o ingresso e a saída de sócios, o montante e condições dos aportes de capital, as condições e os requisitos dos créditos e a forma de operar os serviços.
} 
Desta forma, elas operam como um mecanismo de recirculação, resignação e otimização dos fluxos que gera a economia familiar dos setores onde elas se desenvolvem.

\subsubsection{Consórcios de SPI}

Os Consórcios são uma associação voluntária entre SPI que surgem para conformar uma sociedade mercantil de serviços e para fortalecer seus membros, visando constituir sistemas que facilitem o acúmulo de capital, e assim "constituirse en sistemas que facilitan incursionar en otras formas de inversión, y contribuir a la retención, capitalización y acumulación local de los pequeños excedentes de las actividades económicas de las familias" (CEPESIU, p. 31) ${ }^{106}$.

O capital das SPIs destina-se quase exclusivamente a outorgar créditos, por isso pensou-se nos consórcios como forma de incrementar os lucros e de poder fazer outros investimentos. Por meio dos consórcios se busca instalar de maneira mais sólida, estável e permanente um instrumento local que vise a sustentabilidades, consolidação, desenvolvimento e expansão destas iniciativas (CEPESIU, 2009).

Desta forma, os consórcios se caracterizam por ser uma forma de cooperação empresarial que mediante a interação se complementam em atividades e recursos. Segundo seus idealizadores, eles possuem benefícios sociais, econômicos e administrativos. Entre os primeiros se identifica o fato de "contar con sistemas locales de autogestión y conceder a las organizaciones un destacado reconocimiento que se traduce también en una elevación de la autoestima colectiva al reconocer su verdadero papel de impulsadores de desarrollo" ${ }^{107}$ (CEPESIU, 2009, 32). A respeito do segundo grupo de benefícios:

Las implicaciones del modelo toman especial connotación porque representan un mecanismo de capitalización e inversión, con lo cual aumentan las posibilidades reales de elevar el nivel y la calidad de vida de sus protagonistas y redunda en un fortalecimiento general de las economías locales al retener en su entorno la circulación efectiva

\footnotetext{
${ }^{106}$ Tradução livre da pesquisadora - Constituir-se em sistemas que facilitam incursionar em outras formas de investimento e contribuir à retenção, capitalização e acumulação local dos pequenos excedentes das atividades econômicas das famílias

107 Tradução livre da pesquisadora - Contar com sistemas locais de autogestão e conceder às organizações um destacado reconhecimento que se traduz também em uma elevação da autoestima coletiva, ao reconhecer seu verdadeiro papel de impulsores de desenvolvimento.
} 
de los capitales consolidados ${ }^{108}$ (CEPESIU, 2009, p.33).

Quanto aos benefícios administrativos, os consórcios permitem às SPls se legitimar como sócios empresariais, com todos os direitos e obrigações que isso traz.

\section{O QUE APROXIMA E O QUE DISTANCIA AS EXPERIÊNCIAS ANALISADAS}

Primeiramente, é importante mencionar que a experiência de Bancos Comunitários de Desenvolvimento como vista no Instituto e no Banco Palmas, é única no continente, tem um funcionamento amplo e diverso que não se encontrou na pesquisa realizada sobre este tipo de iniciativas na América Latina.

No entanto, o Equador, por meio de diversas organizações financeiras solidárias, em especial o CEPESIU e seu programa de SPI, escolhido para a pesquisa, apresenta-se como uma experiência igualmente rica pelo caráter inovador de seus programas, e pelo viés político que estas experiências estão atingindo.

A primeira diferenciação que precisa ser feita é que, no caso brasileiro, foi a experiência de um Banco Comunitário, criado por uma associação de bairro, que inspirou a criação de uma instituição para disseminar as experiências: o Instituto Palmas.

No entanto, no caso equatoriano, o primeiro passo foi criar uma organização da sociedade civil que teve como objetivo apoiar pessoas que se encontravam desempregadas ou no setor informal. Somente 15 anos depois de sua inauguração, é que surgiu o Programa Sociedades Populares de Inversión, aproveitando a experiência acumulada pela organização com os outros programas já descritos. Cabe destacar que os créditos formaram parte do trabalho feito pela CEPESIU, desde 1987. Ou seja, o processo deu-se de forma inversa.

Decorrente desta, outra diferenciação importante é que as SPIs são formadas por pessoas que já desenvolvem alguma atividade econômica, mesmo que de forma precária. No caso do Banco Palmas, ele oferece créditos para que, com esses recursos, se formem grupos produtivos.

\footnotetext{
108 Tradução livre da pesquisadora - As implicâncias do modelo tomam especial conotação porque representam um mecanismo de capitalização e investimento, com o qual aumentam as possibilidades reais de elevar o nível e a qualidade de vida de seus protagonistas e redunda em um fortalecimento geral das economias locais, ao reter em seu entorno a circulação efetiva dos capitais consolidados.
} 
No caso do Equador, as ações são feitas em conjunto pelo CEPESIU e as SPI, por isso, em alguns momentos, não há como diferenciar uma da outra, embora as SPIs se originem a partir de outras ações realizadas pelo CEPESIU.

Seguindo com as diferenças, a metodologia de formação da iniciativa também difere em ambos os casos. No caso das SPI, a CEPESIU intervém desde a primeira etapa, na qual identifica, seleciona e propõe o programa para a comunidade, organizações ou grupos e logo apoia tecnicamente por um período de tempo. No caso brasileiro, esse papel é cumprido pelo Instituto Palmas, porém é a base de demanda das comunidades e não há um processo de identificação e proposta que nasça do Instituto Palmas.

Outro aspecto que os distingue é que o Banco Palmas possui um sistema de moeda social circulante local que procura aprimorar o sistema de comercialização local e que segue os padrões de moedas alternativas experimentados em países europeus ou nos Estados Unidos, outros lugares com reconhecido sucesso ${ }^{109}$. A experiência equatoriana não apresenta esse diferencial.

Assinaladas as principais diferenças, a seguir serão mencionados os aspectos que mesmo sem ser exatamente iguais em ambos os casos, aproximam as duas experiências escolhidas.

Tanto o Banco Palmas quanto o Programa Iniciativas Populares de Inversión nasceram no ano de 1998, em meio a um período de reestruturação econômica de grande significado em ambos os países e que iria desenhar os alinhamentos para as próximas décadas, como aprofundado no terceiro capítulo deste trabalho.

Ambas as experiências reconhecem o território como um eixo organizador da atividade econômica e consideram como indispensável o envolvimento dos agentes e atores locais como protagonistas do seu desenvolvimento. Neste sentido, as duas iniciativas mostram ampla abrangência se comparadas dentro de suas características territoriais, concentrando-se em regiões de menor renda. As duas se iniciaram no âmbito urbano, porém o CEPESIU ampliou sua atuação para o setor rural.

Quanto ao financiamento, as SPIs buscam ser autossustentáveis por meio de processos de autogestão, no entanto, em certas ocasiões, recebem apoio financeiro

\footnotetext{
${ }^{109} \mathrm{Na}$ França existe a moeda social SOL, que consiste em um cartão de fidelidade que busca contribuir com o desenvolvimento da economia local, social e solidaria. Outro exemplo são as moedas territoriais como o Berckshare nos Estados Unidos ou as moedas Inter empresas como a WIR na Suiça.
} 
externo para incrementar o fundo de operações, proveniente do CEPESIU que, como foi visto anteriormente, recebe financiamento de diversas fontes. No caso do Banco Palmas, também recebe apoio de diversas fontes e amplia sempre que possível, suas fontes de renda.

Em relação à gestão, as duas são administradas por grupos locais. No caso das SPI, é por grupos de sócios e diretivos de forma voluntária, porém com acompanhamento da CEPESIU e, no caso do Banco Palmas, a administração é feita pela ASMOCONP.

No mesmo plano da gestão, no Brasil, embora formalmente seja administrada por uma organização gestora, há uma liderança clara que idealizou e atualmente é responsável, mesmo que de forma implícita, por disseminar as experiências. No caso das SPIs, também possuem uma liderança local, porém quem faz a disseminação das experiências é a organização que as incubou, no caso a CEPESIU

Em ambos os casos, o crédito é o principal elemento das iniciativas. As duas coincidem no tipo de crédito concedido: para produção e para consumo. Assim, ele se torna um recurso para desenvolver atividades econômicas e também para as necessidades familiares ou pessoais. No entanto, as SPIs visam gerar um sistema de poupança e capitalização, no qual os sócios podem ter acesso a utilidades distribuíveis, em caso de rentabilidades do investimento, e isto não está entre os objetivos do Banco Palmas.

Em ambos os casos, tem o controle da comunidade local que acompanha o processo e os empréstimos. Dado que as garantias que as duas iniciativas exigem são imateriais, a vizinhança cumpre um papel fundamental, pois é ela quem define se o crédito será ou não consignado, em decorrência do tipo de comportamento do tomador do crédito. Os gestores entendem que esta estratégia contribui para garantir o cumprimento no pagamento. Isto é corroborado quando analisadas as taxas de inadimplência, que no caso do Banco Palmas, não supera $2 \%$, e no caso equatoriano é de $6 \%$. Ao respeito disso, Moreno explica que isto:

Ha generado además un descubrimiento revolucionario para el sector financiero: que los pobres pueden ser muy buenos clientes de las entidades financieras. Frecuentemente, mejores que los clientes con mayores ingresos: devuelven más puntualmente y mejor sus 
créditos, soportando condiciones de precios y plazos más exigentes $^{110}$ (MORENO, 2011, p. 3).

Além dos serviços financeiros do tipo bancários, as duas experiências desenvolvem outros tipos de programas e projetos como foram descritos acima. $O$ Banco Palmas, por sua vez, tem uma linha ativa de apoio e desenvolvimento de projetos sociais, que busca melhorar a qualidade de vida das pessoas da comunidade e que vai além da concessão de empréstimos. Desde que foi reconhecido pelo poder público como uma iniciativa de caráter inovador e que apresenta resultados positivos, ganhou novas parcerias e se vinculou ao principal Programa de Transferência de renda do país; sendo que das 5.300 operações de créditos que foram realizadas no ano de 2011, 3.126 foram para mulheres beneficiárias do Programa Bolsa Família.

No caso do Equador, são desenvolvidos projetos sociais que visam a reintegração dos imigrantes e a construção de moradia, entre outros que buscam oferecer assistência que vá além da possibilidade de gerar emprego e renda. Neste caso não se conhecem ações associadas diretamente ao programa Bono de Desarrollo Humano, descrito no capítulo anterior, porém a população atendida pelos programas coincide com a que é beneficiada pelo programa de transferência de renda, já que o CEPESIU atende pessoas com renda abaixo do valor de uma cesta básica, requisito necessário para participar do programa de transferência de renda.

A respeito do papel do Estado, o Banco Palmas conquistou a boa vontade política e, como foi descrito anteriormente, foi este o motivo que incentivou a criação do Instituto Palmas, de forma a replicar a experiência em outras regiões, além de estabelecer estreitas relações com a SENAES. No caso das SPIs, desde 2009 contam com o apoio do Programa Nacional de Finanzas Populares, Emprendimentos y Economia Solidária, pertencente ao governo nacional para consolidar a iniciativa. Através deste programa, se busca potenciar as atividades e capacidades empreendedoras da população, apoiando técnica e financeiramente as iniciativas de finanças populares e fomentando a cooperação de novos e melhores serviços financeiros, de acordo com as diretrizes que o governo equatoriano instaurou a partir do início do atual governo de Rafael Correa.

\footnotetext{
110 Tradução livre da pesquisadora - Há gerado um descobrimento revolucionário para o setor financeiro: que os pobres possam ser muito bons clientes das entidades financeiras. Frequentemente, melhores que os clientes com maiores ingressos: devolvem mais pontualmente e melhor seus créditos, suportando condições de preços e prazos mais exigentes.
} 
Cabe assinalar que ambas as práticas buscam desenvolver projetos produtivos solidários, com a promoção das atividades econômicas locais e, por isso, trata-se de fortalecer as cadeias produtivas e promover vínculos entre elas que possibilitem a maior dinamização do mercado local.

Quando analisados os resultados, tanto o Banco Palmas quanto o CEPESIU e, especialmente as SPIs, mostram-se como alternativas viáveis para atender as necessidades das famílias de baixa renda, permitindo o acesso regular a crédito para pessoas e grupos que não têm acesso ao mercado financeiro formal, suportando o desenvolvimento e a reprodução da economia familiar.

Nos documentos aos quais se teve acesso, ambas as experiências destacam que há uma nova percepção do ser sujeito econômico, contribuindo para o aumento da participação e a autoestima, principalmente no caso das mulheres, que no caso equatoriano, são $65 \%$ dos tomadores de crédito.

Permite, segundo a bibliografia consultada, a possibilidade das famílias planejarem a médio e longo prazo, além de desenvolver habilidades de gestão financeira, administrativa e empresarial por parte dos sócios, que pode ser aplicada em outros âmbitos.

Também se ressalta que estas iniciativas permitiram desenvolver de forma mais articulada a região, estimulando a mobilização de recursos locais, facilitando e dinamizando de fluxos de capital entre as economias regionais baseadas em atividade de autoemprego. Contribuem assim com o desenvolvimento dos mercados financeiros locais e o fortalecimento da organização e do tecido institucional local.

Para finalizar, a aproximação dessas duas experiências traz à tona uma série de questões e algumas perguntas, as quais, nem sempre respondidas, buscaram dar luz a análise.

\section{ECONOMIA SOLIDÁRIA, ECONOMIA DOS GESTORES?}

Não é possível pensar hoje na economia solidária, nem no desenvolvimento de iniciativas de finanças solidárias do tipo do Banco Palmas ou dos Programas de Sociedades Populares de Inversión sem associá-las diretamente aos gestores. As experiências estudadas, assim como outras com as quais se teve contato durante a vida profissional, apresentam uma organização ou pessoa que tutela e media os processos, quando não os faz nascer. 
Segundo Bernardo, e considera-se que os gestores fazem parte, junto com a burguesia, da classe capitalista e são definidos "em função do funcionamento das unidades econômicas enquanto unidade em relação com o processo global" (BERNARDO, 1991, p. 202). Desta forma, são os grupos de gestores que controlam cada instituição que se apropria coletivamente do capital, organizando os processos de trabalho. Com o avanço do capitalismo, os gestores foram assumindo novos papéis e substituindo as funções da burguesia que, como expressa Bernardo, convertera-se em rentistas. "Esta transformação representa uma interiorização porque, sendo o processo de trabalho o mecanismo motor de toda a sociedade, quem prevalecer no seu controle deterá a hegemonia" (BERNARDO, 1987, p. 214).

Quando se pensa em economia solidária e seus gestores, a questão da hegemonia pareceria contraditória, pois no fim, está se falando de processos que visam à democratização e participação. No entanto, se assiste nos últimos anos a uma ampliação exacerbada de instituições que procuram trabalhar neste setor e que ao mesmo tempo fazem a ponte entre as iniciativas locais e o poder público na tentativa de torná-las políticas públicas. Isto torna a economia solidária um campo propício para o desenvolvimento dos gestores e alvo de análise.

Assim, por trás de iniciativas de economia solidária podem ser observados diversos gestores: OSC, instituições de assessoria e fomento, incubadoras universitárias, organizações internacionais, Fóruns, Redes e também o Estado. São instituições que contribuem direta ou indiretamente para a efetivação e desenvolvimento destas experiências, elaborando projetos de geração de emprego e renda destinados a desempregados e/ou população de baixa renda.

Segundo Faria,

Formulam iniciativas de constituição de redes, organizam empreendimentos precários, como os de reciclagem de lixo, propõem programas de capacitação pautados nos valores do empreendedorismo e, enquanto gestores, materializam essas experiências em metodologias e projetos para apresentação às fontes de financiamento públicos e privados (FARIA, 2005, p.360).

Nas experiências estudadas, visualiza-se claramente a atuação dos gestores, mostrando como eles contribuem para a decolagem dos processos. No caso do Banco Palmas, identificam-se dois grandes gestores: a ASMOCONP como associação que gere o Banco e o seu idealizador, Joaquim de Melo Neto, que tem sido muito importante no transcurso do processo e para a disseminação da 
experiência, além de ser quem lidera e quem fala no Brasil e no exterior sobre esta iniciativa. Vale destacar que em diversas oportunidades foi homenageado e tem disputado prêmios em seu nome pela experiência que idealizou e ainda lidera, mesmo sob o discurso de que o Banco é da comunidade. Assim, o Banco é da comunidade, porém é um líder que fala sobre ele.

No caso das SPIs, são iniciativas geridas pelo grupo que as administra, porém há um gestor principal que é o CEPESIU, que, como foi mencionado acima, é uma organização social que nasce por iniciativa de três profissionais que buscavam, 27 anos atrás, oferecer alternativas para a população desempregada do Equador. Da mesma forma que no Banco Palmas, há lideranças fora do grupo de trabalhadores que operam como tutores.

Este contexto deixa difusos os limites entre o que os gestores 'defendem' e o que 'perpetuam', pois no fim, acabam assumindo um papel de controle dos processos produtivos, mesmo sob os princípios da economia solidária, em um procedimento que tende a colocá-los do lado dos exploradores e contra os EXPLORADOS (BRUNO, 1986).

Assim, se hierarquizam novamente os processos produtivos, os gestores se tornam mediadores e se desenvolvem enquanto pessoas e enquanto instituições, porém o processo de emancipação fica, de novo, truncado. As comunidades locais que participam dos Bancos se submetem conscientes, ou não, aos processos dirigidos pelos gestores que acreditam no potencial destas iniciativas e realizam a estrutura para que sejam efetivas. Formas mais legítimas talvez, porém, que reproduzem o sistema de dominação e contribuem de forma direta, para esta nova forma de governar e de reprodução da força de trabalho.

É o fenômeno da cooptação tomando corpo, como já o fez com o movimento operário, com os sindicatos, e com os movimentos sociais que inicialmente destinados para a destruição do modo de produção capitalista, acabaram convertendo-se em formas novas de dominação e realização do próprio capitalismo. 


\section{SER SOLIDÁRIO: COISA DO DESTINO?}

Outro aspecto muito relevante que aparece quando estudadas as experiências de finanças solidárias dentro do fenômeno do empreendedorismo é o que pode ser chamado de "imposição da solidariedade". A solidariedade aparece como um acontecimento implícito dentro desta dinâmica, como se ela fizesse parte de um processo natural que se dá entre os seres humanos e que viria a contracenar com os princípios individualistas do capitalismo.

A criação, por parte das organizações gestoras, de veículos que potencializem a comunicação entre os indivíduos, o incentivo para a formação de grupos produtivos coesos, a integração de pessoas e projetos em redes locais, globais e virtuais, permite ver o amplo investimento que está sendo feito para potencializar esta questão e que vem ao encontro dos princípios que predominam na economia solidária, já descritos no capítulo III.

O caráter de solidariedade nos empreendimentos se evidencia em diferentes dimensões, tais como na distribuição equitativa dos resultados alcançados; nas oportunidades que levam ao desenvolvimento de capacidades e da melhoria das condições de vida dos participantes; no compromisso com o meio ambiente; nas relações que se estabelecem com a comunidade local; na participação ativa nos processos de desenvolvimento sustentável de base territorial, regional e nacional; nas relações com os outros movimentos sociais e populares de caráter emancipatório; na preocupação com o bem-estar dos trabalhadores e consumidores; e no respeito aos direitos dos trabalhadores e trabalhadoras.

Resulta ilustrativa a história de Maria, contada por uma equipe de gestores e resumida a seguir:

A dura rotina de Maria, porém, não apaga de seu rosto o ar de alegria e felicidade, pelo simples fato de estar vivendo. Maria Alves dos Santos, 47 anos, duas filhas e três netos convive com o mal de Chagas e a disritmia. Quando a dor vence sua obstinação pela produção de farinha, ela para e vai costurar em casa. Mas, já que não pode carregar peso, carrega a certeza de que o trabalho é o melhor remédio para mantê-la de pé. A história de Maria não é exclusiva, há outras bem parecidas no grupo de 26 mulheres que mantêm viva uma tradição secular: a fabricação da farinha de mandioca e do polvilho. Enquanto trabalham, contam histórias, dão boas risadas e vão tocando a vida. Juntas, formam a Associação das Mulheres de Santa Fé, cidadezinha com pouco mais de $7 \mathrm{mil}$ habitantes, a $260 \mathrm{~km}$ de Goiânia. Incentivadas por uma freira dominicana, as mulheres começaram a fazer colchas de retalho 
recebendo doações da comunidade local e apoio de organizações internacionais que doaram máquinas e tecido. Mesmo com toda a dedicação, a tentativa esbarrou na falta de prática das associadas e no fraco mercado para o produto. Foi então que surgiu a ideia da farinha, já que todas sabiam como se fazia. Em mutirão, construíram um rancho de palha e chão batido e lá fincaram as raízes da associação. Naquele tempo, a ideia de se trabalhar em parceria era vista como subversiva, e elas não contavam nem com a simpatia dos próprios maridos. Contudo, a amizade entre elas se fortaleceu, e a associação ganhou respeito. Como em um formigueiro, cada uma sabe muito bem da sua missão, num verdadeiro exemplo de como viver em harmonia numa comunidade. ${ }^{111}$

Assim, como no caso da Maria, é comum ver como muitos dos empreendimentos coletivos surgem a partir de estímulos de grupos externos, como é o caso claro da CEPESIU, que enxergam uma necessidade que nem sempre é sentida pela comunidade, porém aceita e bem recebida. No decorrer desta pesquisa foi possível constatar que a formação de grupos empreendedores se origina muitas vezes a partir da exigência que colocam os grupos gestores para conceder microcréditos, já que eles entendem que o trabalho coletivo geraria maior sustentabilidade para as iniciativas. No caso de ambas as experiências, os créditos para produção são sempre concedidos a grupos de pessoas.

No entanto, muitas vezes, trata-se de pessoas que mesmo morando na mesma comunidade não se conhecem, embora compartilhem uma mesma situação: a miséria e a falta de emprego. Porém, isto não as faz pessoas parecidas nem com afinidade o ponto de dividir um empreendimento e uma vida.

O simples fato de compartilharem uma situação econômica e social parecida não transforma indivíduos em coletivos, do mesmo modo como integrar programas de geração de emprego e renda ancorados em iniciativas de economia solidária não faz as pessoas serem solidárias por natureza. Este sentimento é muitas vezes imposto pela necessidade. Uma necessidade criada pelos atores que dividem o campo de atuação e que em algum momento, baseados em condições internas e externas, acreditaram que a solidariedade também tem preço. $E$ talvez de fato o tenha, pois em troca de melhores condições de vida, os indivíduos compram o discurso e se empenham em colocá-lo em prática, testemunhando mais uma estratégia que contribui nesta arte de governar os sonhos, os desejos e o mero viver.

111 Revista SEBRAE n. 7 nov.-dez./2002, seção "Uma história de vida", disponível em www.sebrae.com.br/revistasebrae/07/index.htm. Acesso em novembro de 2010 
Em palavras de Foucault:

(...) É necessário por tanto, ao mesmo tempo em que se implanta uma política tal que a concorrência possa agir economicamente, organizar "um quadro político e moral" diz Ropke, um quadro político e moral que comporte o quê? Primeiro, um Estado que seja capaz de se manter acima dos diferentes grupos concorrenciais e das diferentes empresas em concorrência umas com as outras. É necessário que esse quadro político e moral assegure uma comunidade não desagregada e enfim, garanta uma cooperação entre os homens naturalmente enraizados e socialmente integrados (FOUCAULT, 2008a, p.333).

As políticas sociais do século XX e começo do século XXI atuam claramente no sentido descrito acima. Parcerias estabelecidas entre o poder público e as organizações da sociedade civil garantem a atenção da população de baixa renda, por meio de programas assistenciais que se complementam com outros mais audaciosos, como são os de geração de emprego e renda. No entanto, nas últimas décadas, os conceitos de autogestão, empreendedorismo, cooperação e redes vêm sendo discursiva e operacionalmente aplicados em cada uma destas iniciativas, responsabilizando os seus "beneficiários" pela "sorte" de seu acaso, legitimados com valores instituídos e necessários para uma correta administração e principalmente, gestão da pobreza.

E assim, por fim, numa complexa trama, atores diversos fazem da arte de governar a forma discreta e menos custosa de administrar os desejos e produzir novos sonhos. Fabricam-se novos indivíduos que em uma constante relação de força aceitam as predições do "destino", numa sociedade que cria e recria novas formas de interagir e sobreviver, investindo em estratégias alternativas que exijam mínima intervenção financeira do Estado, porém máxima no quesito "intervir para prevenir".

\section{SER EMPREENDEDOR: OPÇÃO OU IMPOSIÇÃO?}

Entre as mutações observadas no mundo do trabalho e nas relações que se estabelecem em torno delas, pode se observar, a partir do início do século $\mathrm{XXI}$, o surgimento do empreendedorismo como um fenômeno atual, relativamente pouco estudado e que é responsável por assegurar a participação no mercado de trabalho de um contingente importante de indivíduos. 
Desde o século XVIII, época que pode ser encontrada sua origem, eram chamadas de empreendedoras as pessoas que por elas mesmas tomavam a iniciativa de alguma empresa ou negócio, enfrentando os riscos e a incerteza frente aos rendimentos e retornos futuros (PUELLO SOCARRÁS, 2010).

No entanto, na atualidade, esta consideração ressuscitou e coube também para um novo público: desempregados ou trabalhadores informais que desenvolvem atividades de forma autônoma ou coletiva, criando pequenos empreendimentos produtivos. É esta concepção que pode ser encontrada quando analisadas as experiências de finanças solidárias destacadas neste trabalho.

Entre as variadas dimensões que adota a economia solidária, foi possível observar anteriormente que ela inclui o trabalho autônomo de indivíduos e/ou de coletivos, sendo que se diferencia da economia tradicional por envolver valores e princípios cooperativos e solidários. Se bem que não se possa atribuir o surgimento do empreendedorismo às políticas de economia solidária, se entende que ela favorece o desenvolvimento destes empreendimentos, já que parte de suas estratégias é gerar mecanismo de geração de trabalho e renda que contribuam para melhorar a qualidade de vida de setores vulneráveis. Neste contexto, é que se observa a relevância da passagem da figura do trabalhador que cede espaço para a do empreendedor.

Empreendedor que deve ser inovador, criativo e parceiro. Atributos fundamentais para fazer parte da nova estrutura, e se essas são características que não possui, haverá organizações que o ajudem a descobri-las. Espalhadas por todo o país, como o caso do CEPESIU e do Instituto Palmas, elas oferecem programas de qualificação que abordam temas tais como: empreendedorismo, administração, gestão do dinheiro, negócios, entre outros. Também faz parte de suas atividades o apoio, consultoria e acompanhamento na formalização destes empreendimentos, que muitas vezes se constituem em microempresas, inclusive contribuem na busca pelo microcrédito e capital de giro inicial, como visto anteriormente.

Assim, as habilidades exigidas para este novo papel serão aquelas que lhes permitirão definir claramente seus objetivos, os meios para alcançá-los e as formas de abordar eficientemente os riscos em um entorno socioeconômico complexo (FIGUEROA, 2003).

Isto faz supor que todos os membros da sociedade são potenciais competidores, e que o sucesso está assegurado pelo esforço pessoal, mudando o 
tipo de relações de intercâmbio estabelecidas. Neste contexto, o sujeito precisa se enxergar e instituir como empreendedor responsável pelo seu sucesso e seu fracasso numa sociedade ocidental moderna disposta a recebê-los.

Neste sentido, embora nestes programas, tanto no Equador como no Brasil, (e também em outros países que as desenvolvem), a concessão dos créditos e os outros serviços do banco privilegiem a atuação em grupos, percebe-se que a responsabilização individual está presente em todo o processo, reproduzindo assim, um dos corolários do neoliberalismo que é a responsabilização do individuo. Desta forma, o grupo é utilizado como uma garantia para o Banco, mas, ao mesmo tempo, responsabiliza-se unicamente o indivíduo que tomou o crédito pelo desenvolvimento de um negócio que dê lucro, pelo cumprimento com o grupo, pela sustentação do seu 'status de pagador' frente à comunidade, conformando o quadro disciplinar do capitalismo contemporâneo presente na vida cotidiana.

Junto com isso, conforma-se um modelo de sujeito que este quadro disciplinar determina. Os efeitos disciplinares do trabalho fabril cedem espaço aos efeitos disciplinares do trabalho por conta própria. O chefe continua existindo: é ele mesmo. As oito horas de trabalho viram doze, e as horas extras não entram na folha de pagamento.

No entanto, para muitos, ser um empreendedor significa uma oportunidade de inserção econômica, mas também de inserção social. Muitos dos participantes desta nova cadeia produtiva são inseridos em redes sociais, estabelecem novos e diversos vínculos, conquistam a independência econômica, adquirem diversas habilidades e ampliam o leque de oportunidades. Paralelamente, o Estado direta ou indiretamente mantém estas iniciativas e cria necessidades que garantam a permanência destes projetos, deixando em evidência o que magistralmente Foucault expõe: "o poder é cada vez menos o direito de fazer morrer e cada vez mais o direito de intervir para fazer viver, e na maneira de viver, e no "como" da vida" (FOUCAULT, 2005, p. 295).

Neste sentido, é importante retomar a concepção de homo oeconomicus trazida por Foucault, entendendo o individuo, no neoliberalismo, como um empresário de si mesmo e já não mais como um parceiro de troca. O atual homo oeconomicus é por ele mesmo capital, produtor e fonte da própria renda; produtor, em primeira e última instância, de sua própria satisfação (Foucault, 2008). Assim, ele se torna governável, "aparece justamente como o que é manejável, o que vai responder sistematicamente a modificações sistemáticas que serão introduzidas 
artificialmente no meio" (FOUCAULT, 2008, p.369). Neste sentido, as políticas públicas adotadas pelo governo em relação ao assunto abordado chamam a atenção por promoverem formas que individualizam as responsabilidades em detrimento de ações sociais coletivas que poderiam ter maior capacidade de garantir direitos sociais. No dizer de Meneleu Neto, "Do mesmo modo que o capital financeiro se libertou do controle do Estado Nação, o capital produtivo passou a exigir um mercado de trabalho o mais possível desregulamentado" (1998. p. 80).

Trata-se assim, de uma forma de governar implícita, difusa, diferente daquela do século $X V$ que se baseava fundamentalmente no governo do espírito por meio da religiosidade, diferente também da que exibiam os professores, agentes de segurança, diferente das convencionais formas de dirigir as ações dos seres humanos. Esta é uma nova forma, também eficaz, que enquanto desvenda novas alternativas frente a velhos problemas, impede a revolta e minimiza os efeitos do desconforto, até porque este, muitas vezes, nem é percebido, assistindo assim à

Transição de um poder de Estado soberano, que operava negativamente pela colocação de limites e coerções, para um poder disciplinar descentralizado que penetra nossas almas, corpos e mentes, transformando-os ativamente e produzindo efeitos positivos que nos tornam a todos cidadãos autodominados (KRIEKEN, 1996, p. 155).

Colocada esta série de questões, entende-se que é na observação crítica dos fatores que constituem as novas formas de trabalho, onde radica a importância de analisar a passagem do indivíduo trabalhador para o indivíduo empreendedor, atendendo às mudanças significativas que aconteceram desde a década de 1990, com o auge do neoliberalismo, e olhando para os limites e possibilidades que as novas formas de produção e reprodução da força de trabalho, oferecem. Trata-se de uma passagem complexa, de múltiplas interpretações, não imune às relações de poder que permeiam a vida econômica, social e política de um Estado e de uma sociedade. 


\section{CONSIDERAÇÕES FINAIS}

A pesquisa realizada evidenciou que o processo de produção e reprodução da classe trabalhadora adotou diferentes estratégias, segundo os períodos analisados, porém sempre esteve vinculado com formas de governo que se adaptam e contribuem para o seu sucesso. Formas estas, não sempre aparentes, nas quais participa um conjunto de agentes, uns mais ativos que outros, dependendo do momento de referência e que no fim, contribuem para perpetuar o funcionamento do sistema capitalista e suas estratégias de sobrevivência.

No fim do século XX e início do século XXI, é possível observar uma grande sofisticação das técnicas de controle, que tem ao Estado como aliado, mas não só. Organismos internacionais, organizações sociais, corporações empresariais e gestores, fazem parte da constelação de agentes, necessárias para sua mutação e disseminação, como abordado no capítulo II deste trabalho. Deste modo, de acordo com Novaes: "ao longo dos períodos históricos, as coalizões que comandam o Estado passam a difundir nas suas diversas instituições uma determinada ideologia coerente com as suas necessidades" (NOVAES, 2011, p. 181). E, mesmo quando surgem movimentos que procuram caminhar no sentido contrário são cooptados, tornando-se, de uma u outra forma, úteis ao sistema capitalista.

O caminho da economia solidária ainda é curto, não há como afirmar que ela é mais um aliado do sistema capitalista, nem que vai se deixar cooptar, porém as experiências analisadas oferecem elementos que mais aproximam do que distanciam da hipótese de que seria, no fim, mais uma forma de produção e reprodução da força de trabalho, tutelada e assistida, constituindo-se na mais nova (e aceita) forma de gestão da pobreza.

A questão está longe de ser simples, e menos ainda, resolvida. Assim, por um lado, há tendências fortes que levam a pensar este fenômeno como mais um elemento que consolida as novas formas de governo, diferentes das conhecidas no capitalismo tanto nas suas fases iniciais como no pós-segunda guerra, como pode ser visto nos dois primeiros capítulos desta dissertação. Por outro lado, a economia solidária está no começo e vem apresentando resultados alentadores quanto às mudanças imediatas na qualidade de vida da população de baixa renda que a ela adere. 
No entanto, esta última constatação não invalida a primeira, já que o fato dos empreendimentos de economia solidaria serem promissores enquanto a resultados, não deveria surpreender, pois se tratando de uma estratégia de produção e reprodução, ela tem que poder modificar. A melhoria na qualidade de vida dos trabalhadores é condição necessária para a produção e reprodução acontecer, e por isto, é necessário garantir, em primeiro lugar, um certo nível de sobrevivência para a classe trabalhadora, já que só assim, ela poderá continuar existindo e servindo ao capital.

Esse nível de sobrevivência tem sido garantido por políticas sociais, que como amplamente abordado no capítulo II, mudaram seu perfil nos últimos 20 anos, e em especial na última década. Estas vêm apresentando uma grande tendência a se agrupar em programas de renda condicionada e as que dirigidas å classe trabalhadora, a se unificar em programas de geração de emprego e renda, que seguem os padrões internacionais.

Exemplo disto é a popularização dos créditos para a população de baixa renda e que se tornaram o principal produto financeiro dos BCD estudados, como pode ser visto no capítulo IV deste trabalho. $\mathrm{O}$ crédito para produção e o crédito para consumo formam um par inseparável que faz com que as pessoas passem de pobres para endividadas, sob a sedução de ser empreendedor e logo, consumidor. O trabalhador é atraído por estes incentivos que não são apenas midiáticos, (embora a mídia contribua para seu convencimento), trata-se, muitas vezes, da única opção. A falta de alternativa vira sinônimo de imposição, e é este jogo que faz aparecer uma nova forma de controle e coerção. Nem sempre existe no crédito o fim da pobreza, mas sempre existe o início de um ciclo de dívidas, e também a possibilidade de sobreviver, e aqui radica mais uma das múltiplas contradições que apresenta a economia solidária no sistema capitalista. E assim, o capital define, como em todos os séculos anteriores, a forma como se organiza a vida.

Além disto, observou-se durante a pesquisa que as experiências estudadas acontecem no mundo inteiro. No caso do Equador, por exemplo, a inspiração provém de uma experiência realizada por um estadunidense nas comunidades andinas. Trata-se de práticas globais que acontecem no mundo todo e que trazem à tona a mundialização da classe trabalhadora, do capital e também de suas estratégias. 
No entanto, é a participação ativa dos Estados Nacionais que as viabiliza e sustenta, incluindo-as em seu plano de contenção e controle. Nesse sentido, Dagnino expressa:

A condição do Estado como fiador e organizador da sociedade capitalista e do processo de reprodução do capital tende a ser mascarada (e, no limite, negada) pela mediação que estabelece com a sociedade. Elas minimizam (ou ignoram) as clivagens da classe e confinam à sociedade ao "privado" e ao econômico (mercado) e reserva ao Estado o domínio sobre o público e o político. O Estado capitalista é, então, a expressão político-ideológica da agenda produzida pela relação social que garante a reprodução e a naturalização de uma ordem social necessária à acumulação de capital (DAGNINO, 2011, p. 362-363).

Desta forma, a participação do Estado nestas iniciativas é de fundamental importância, como se pode constatar nas práticas analisadas. Isto acontece por meio de parcerias com OSC e corporações empresariais, mas também por meio de ações estatais como no caso do Brasil, que foi criada uma Secretaria de Economia Solidária para cuidar destes assuntos, não casualmente na órbita do TEM, ou, como no caso do Equador, onde a concepção de economia solidária é incluída na Constituição do país. Isto pode ser visto como um avanço quanto ao compromisso do Estado com o bem-estar da classe trabalhadora que não tem emprego, mas também pode ser entendido como uma forma eficaz de cumprir seu papel de organizador da sociedade, neste caso a capitalista, evitando o caos e garantindo sua reprodução.

Reprodução que requer um exército industrial de reserva preparado para trabalhar, uma estrutura que lhe permita sobreviver até o momento em que seja "o escolhido" e uma condição que o mantenha satisfeito, para que não pense em reclamar, menos ainda, em se mobilizar. Melhor se pensa que é livre porque isso significaria que acreditou em um dos principais legados do neoliberalismo difundido desde o final do século $X X$.

O que é isto senão, novas formas de governo? É o governo das subjetividades, o governo dos sonhos, dos desejos, mediado pelas relações de poder que mudam de forma, mas não mudam de objetivo.

Esta forma (de poder) exerce-se sobre a vida quotidiana imediata, que classifica os indivíduos em categorias, os designa pela sua individualidade própria, liga-os a sua identidade, impõe-lhes uma lei de verdade que é necessário reconhecer e que os outros devem reconhecer neles. É uma forma de poder que transforma os 
indivíduos em sujeitos. Há dois sentidos para a palavra "sujeito": sujeito submetido a outro pelo controle e a dependência e sujeito ligado à sua própria identidade pela consciência ou pelo conhecimento de si. Nos dois casos a palavra sugere uma forma de poder que subjuga e submete (Foucault, 1995, p. 235).

E enquanto isso, o Estado cumpre seu papel regulador, governante dos seus governados, que na arte de governar exerce o poder segundo o modelo econômico imperante, no caminho de "Utilizar mais tácticas do que leis ou utilizar ao máximo as leis como táticas. Fazer por vários meios que determinados fins possam ser atingidos" (FOUCAULT, 1979, p. 284). Desta forma, desejos são instituídos pela própria sociedade, ao mesmo tempo em que o Estado procura garantir as condições para fazer deles, um projeto de vida.

Assim, a sociedade contemporânea desfruta de um governo menos explícito, mais barato e mais coercitivo, que investe em criar necessidades que suprirá por meio dos seus próprios demandantes, de forma tal que possa atingir os melhores resultados econômicos. Para isto, utiliza-se do "indivíduo empresa" onde a pessoa se gere a si própria e à sua vida, sendo responsável primeiro e último pela sua sorte (ou a falta dela).

Para finalizar, interessa destacar que esta dissertação buscou mostrar as diferentes fases da produção e da reprodução da força de trabalho e as estratégias que mediaram este processo e o fizeram acontecer nos diferentes períodos históricos. Mas, principalmente, se propôs a colocar em evidência as estratégias utilizadas na atualidade, para "estender sobremaneira o controle do capital sobre todos os que só podem sobreviver colocando sua capacidade de trabalho a serviço de outrem" (BRUNO, 2012, sem publicar).

Outros poderiam ter sido os exemplos, mas foi encontrado no BCD e na economia solidária um terreno fértil para analisar estes elementos. A questão é complexa e possui muitas faces, e o objetivo desta análise não é invalidar os avanços que vêm tendo a economia solidaria, até porque se trata de um processo em construção.

No entanto, o olhar e a análise crítica permite estarmos alerta frente às possibilidades da economia solidária ser utilizada como uma forma de eliminar as responsabilidades políticas e institucionais existentes, sob a sedução de suas oportunidades. Nesse sentido, e de acordo com o estudado durante esta pesquisa, é 
preciso considerar uma vertente não só presente, como muito forte nessas experiências de economia solidária, que é a de reduzi-las a novas estratégias de produção e reprodução da força de trabalho vivificando o capital e adormecendo os trabalhadores. 


\section{REFERÊNCIAS BIBLIOGRÁFICAS}

ARENDT, H. La condición humana. Barcelona: Editorial Paidós, 1993.

ARMAS, A. La equidad de género y el programa del bono de desarrollo humano. Informe de Investigación, Quito: CEPAL-CONAMU, 2004.

ALARCON COSTTA, C. Sector Informal ¿Problema o Solución? Quito: Editorial Sandoval Hnos, 1989.

ALARCON COSTTA, C. Al Futuro con la Microempresa. 1ed. Quito, 2001.

ALVES, F. Políticas de apoio à economia solidária no Brasil. In: FRANÇA FILHO \& OUTROS, Ação pública e economia solidária: uma perspectiva internacional. Porto Alegre: UFRGS, 2006.

ALVES, O.; BURSTYN, M. Raízes e Prática de Economia Solidária: articulando economia plural e dádiva numa experiência do Ceará. Revista Econômica do Nordeste. v. 40, n. 03, jul./ set. 2009.

ANTUNES, R. Neoliberalismo, Trabajo e Sindicatos, Reestructuração produtiva no Brasil e na Inglaterra. São Paulo: Ed. Boitempo, 1997.

ANTUNES, R. Adeus ao Trabalho? Ensaio sobre as metamorfoses e a centralidade do mundo do trabalho. São Paulo: Ed. Cortez-UNICAMP, 1995.

ARCE C, C.; PALOMEQUE V, E. Del mito al debate. Las ONG en Ecuador. Quito: Ediciones Abyayala, 1997.

BALBIS, J. ONGs, Gobernancia y Desarrollo en América Latina y el Caribe. Gestión de las Transformaciones Sociales (MOST). Documentos de debate - $n^{\circ} 53$. UNESCO, 2001

BANCO MUNDIAL. Informe Anual. 1997. Disponível em: <www.worldbank.org> Acesso em: jan de 2011.

BANCO MUNDIAL. Las políticas de transferencia de ingresos en Uruguay: cerrando las brechas de cobertura para aumentar el bienestar. Oficina Regional para América Latina y el Caribe. Buenos Aires, Argentina. Banco Mundial, 2007. 
BARAIBAR, X. Aptitud e inaptitud para el trabajo: transformaciones en los sistemas de protección social. Revista Serviço Social e Sociedade, n 72. São Paulo: Cortez, 2002.

BARAIBAR, X. Las Paradojas de la Focalización. Revista Ser Social, n 12. Brasília, 2003

BARAIBAR X. Avance insuficiente: el caso del Ingreso Ciudadano en el Uruguay. Revista Políticas Públicas São Luis, v. 13, n. 2, p. 161-171, jul./dez. 2009.

BARBA, C. La reforma social en América Latina: regímenes de bienestar en transición. Quito: FLACSO, Quito, 2003.

BARBOSA, R. A economia solidária como política pública. São Paulo: Cortez, 2003.

BARONE, F. M.; SADER, E. Acesso ao crédito no Brasil: evolução e perspectivas. Rev. Adm. Pública, Rio de Janeiro, v. 42, n. 6, dez 2008. Disponível em: $<$ http://www.scielo.br/scielo.php?script=sci_arttext\&pid=S0034-

$76122008000600012 \&$ Ing=en\&nrm=iso>. Acesso em: jan. 2012.

BARROS DE CASTRO, A.; PIRES DE SOUZA, F. A economia brasileira em marcha forçada. Rio de Janeiro: Paz e Terra, 1985.

BENINI, E. A. Sistema Orgânico do Trabalho: uma perspectiva de trabalho associado a partir das práxis de Economia Solidária. In: BENINI, E \& OUTROS (orgs.) Gestão Pública e sociedade: fundamentos e políticas públicas de economia solidária. São Paulo: Outras Expressões, 2011.

BEHRING, E. R. Política Social no Capitalismo Tardio. São Paulo: Cortez Editora, 2002.

BERNARDO, J. Estado: a silenciosa multiplicação do poder. São Paulo: Escrituras Editora, 1998.

BERNARDO, J. Capital, sindicatos e gestores. São Paulo: Vértice, 1987.

BERNARDO, J. Economia dos conflitos sociais. São Paulo: Cortez, 1991.

BERTAUX, D. Destinos Pessoais e Estruturas de Classe. Rio de Janeiro, Zahar, 1979.

BERTUCCI, J de O. A produção de sentido e a construção social da economia solidária. Tese de doutorado - Brasília, Universidade de Brasília, 2010. 
BID. La política de las políticas públicas: Progreso económico y social en América Latina, 2006. Disponível em: <www.iadb.org>. Acesso em: dez. 2010.

BIHR, A. Da grande noite à alternativa: o movimento operário em crise. São Paulo: Boitempo, 1998.

BOITO Jr, A. O sindicalismo brasileiro nos anos 80. Rio de Janeiro, Paz e Terra, 1991.

BOITO Jr. A. Estado e burguesia no capitalismo neoliberal. Revista Sociologia Politica Curitiba, n. 28, 2007.2 Disponível em: www.scielo.br/scielo.php?script=sci_arttext\&pid=S0104-

44782007000100005\&lng=en\&nrm=iso>. Acesso em: jun. 2011.

BOSI A de P. Ré-forma Sindical do Governo Lula/CUT. Observatório do Mundo Contemporâneo. Ed. $06 . \quad$ Disponível em: <http://www.unioeste.br/projetos/observatorio/reforma_sindical.asp/>. Acesso em: set. 2011.

BRESSER PEREIRA, C; CUNILL GRAU, N. Entre el Estado y el mercado: lo público no estatal. In: Lo público no estatal en la reforma del Estado. Buenos Aires: Editorial Paidos, 1998.

BRESSER PEREIRA, L. A Reforma do Estado dos Anos 90. Brasília: Cadernos do Mare, 1997.

BRUNO, L. O que é Autonomia Operária. 1ª. ed. São Paulo: Brasiliense, 1983.

BRUNO, L. Gestores: a prática de uma classe no vácuo de uma teoria. In: BRUNO L.; SACCARDO, C (orgs.). Organização, Trabalho e Tecnologia. $1^{a}$ ed. São Paulo: Atlas, v. 1, p. 115-149, 1986.

BRUNO, L. Poder Político e Sociedade: qual sujeito, qual objeto? In: FERREIRA BARTOLOZZI, E.; ANDRADE OLIVEIRA, D. (orgs.). Crise da escola e políticas educativas. $1^{\text {a }}$ ed. Belo Horizonte: Autêntica, v. 1, p. 81-139, 2009.

BRUNO, L. Reestruturação capitalista e Estado Nacional. In: OLIVEIRA, D. A. E DUARTE, M. R. T. (orgs.). Política e trabalho na escola. Belo Horizonte: Autêntica, 1999 , p. $13-41$

BUSTELO, E. ¿ ¿Retornará lo social?, Iconos 17, Quito: FLACSO, 2009. 
CACCIAMALI, M.C. Mudanças na Natureza da Política Pública e do Mercado de Trabalho na América Latina. In: KON \& OUTROS (orgs.) Costos sociales de las reformas noeliberales en América Latina. Pontifícia Universidade Central de Venezuela. p. 67-76, 2000.

CACCIAMALI. M. C.; BRAGA, T. Políticas públicas voltadas para o setor informal. In: CHAHAD, J. P. Z. (orgs.). Estudos e análise com vistas à definição de políticas, programas e projetos relativos ao mercado de trabalho brasileiro. São Paulo: FIPE/MTE. Relatório de Pesquisa, 2002.

CACCIAMALI, M. C.; JOSE-SILVA, M. de F. Mais informalidade, menos cidadania. Os efeitos criados por esse circulo vicioso sobre a formulação da Politica Social na América Latina. Cadernos PROLAM/USP. Ano 2. v 02. n 2. 2003.

CALDERÓN, F.; JELIN, E. Classes sociais e movimentos sociais na América Latina: perspectivas e realidades. Revista Brasileira de Ciências Sociais, n 5, v 2, out, p. 6785. 1987.

CANDIA, J.M. Exclusion y pobreza. La focalizacion de las politicas sociales. Nueva Sociedad. Caracas, n. 156, p.116-126, jul./ago. 1998

CASTEL, R. De la exclusión como estado a la vulnerabilidad como proceso. Revista Archipielago n 21. Barcelona: Archipiélago, 1995.

CASTEL, R. As Metamorfoses da Questão Social. Petrópolis: Vozes, 1998.

CASTEL, R. La inseguridad social. ¿Qué es estar protegido? Buenos Aires: Manantial, 2004.

CASTELLS, M. Globalización, Identidad y Estado en América Latina. PNUD, 1999.

CATTANI, A. D. Trabalho e autonomia. Petrópolis: Vozes, 2000.

CATTANI, A. D. A outra economia. Porto Alegre: Veraz, 2003.

CEPAL. Focalización y Pobreza. Cuadernos de la CEPAL. 71. Santiago de Chile: CEPAL. 1995.

CEPESIU. La microempresa de los 90 en Ecuador. 2001. Disponível em: <www.cepesiu.org>. Acesso em: mar. 2011.

CEPESIU. Las Sociedades Populares de Inversión. 2009. Disponível em: <www.cepesiu.org> Acesso em: mar. 2011. 
CEPESIU. Memoria de Gestión 1983-2009. 2010. Disponível em: <www.cepesiu.org>. Acesso em: mar. 2011.

CleAVER, H. Leitura Política de O Capital. Trad. Waltensir Dutra. Rio de Janeiro: Zahar, 1981.

CLEMENTE, A.; GIROLAMI, M. Territorio, emergencia e intervención social. Buenos Aires: Espacio, 2006.

COELHO, F. D. ; FONTES, A. Expansão do Setor de Microfinanças no Brasil.. Rio de Janeiro: IBAM/Fundação FORD. v. 1. 2003.

COELHO, F. D. Finanças Solidárias. In: CATTANI, A, D. (org.). La otra economía. Buenos Aires: Altamira. p. 261-276, 2004.

COELHO, M.P.; DINIZ, E. Gobernabilidad, gobierno local y pobreza en Brasil, In: A. RODRÍGUEZ; L. WINCHESTER (orgs.) pp. 99-152, 1997.

COGGIOLA, O. Da revolução industrial ao movimento operário. As origens do mundo contemporâneo. Artigo publicado no Grupo de Pesquisa História e Economia Mundial Contemporâneas. $1997 . \quad$ Disponível em: <http://www.scribd.com/doc/64922573/1/A-Historia-Muda-de-Rumo>. Acesso em: ago. 2011.

COGGIOLA, O. Os inícios das organizações dos trabalhadores. Aurora, ano IV, n 6, ago. 2010.

COGGIOLA, O. (org.). América Latina e a globalização. São Paulo: PROLAM/FFLCH/USP, 2004.

CORAGGIO, J. L. Da economia dos setores populares à economia do trabalho, In: KRAYCHETE, G.; LARA, F e COSTA, B. (orgs.). Economia dos setores populares: entre a realidade e a utopia. Petrópolis: Vozes, 2000.

CORAGGIO, J. L. De la emergencia a la estrategia. Más allá del 'alivio a la pobreza'. Buenos Aires: Espacio, 2004.

CORAGGIO, J. L. Economía social, acción pública y politica: hay vida después del neoliberalismo. Buenos Aires: Circus, 2007.

CORAGGIO, J. L. La economía social y la búsqueda de un programa socialista para el siglo XXI. Revista Foro, Los socialismos del Siglo XXI. Opciones en debate, n 62, pág. 43-44. Bogotá. 2007b. 
CORAGGIO, J. L. La economía popular solidaria en el Ecuador. 2010 (s/d).

COSTA, M. A. N. As mudanças empresariais no Brasil Contemporâneo: o investimento social privado é uma nova forma de solidariedade? Tese de Doutorado - Instituto de Planejamento Urbano e Regional (UFRJ/IPPUR). 2006.

COSTA M da S. O Sistema de Relações de Trabalho no Brasil: alguns traços históricos e sua precarização atual. Revista brasileira de Ciencias Sociais, São Paulo, $\quad$ v. 20, $\quad \mathrm{n} \quad 59, \quad 2005$. Disponível em: <http://www.scielo.br/scielo.php?script=sci_arttext\&pid=S010269092005000300008\&Ing=en\&nrm=iso>. Acesso em: set. 2011.

CUNHA, G. Políticas Públicas de economia solidária enquanto ressignificação das relações Estado - Sociedade: alguns elementos teóricos e empíricos. Anais do II Seminário Nacional Movimentos sociais, participação e democracia. Núcleo de Pesquisa em Movimentos Sociais. NPMS. UFSC, Florianópolis, 2007.

DAGNINO, R. Em direção a uma estratégia para a redução da pobreza: a Economia Solidária e a adequação sócio-técnica. 2004. Disponível em: <http://www.campusoei.org/salactsi/rdagnino5.htm>. Acesso em: jul. 2011.

DAGNINO, R. Gestão social e gestão pública: interfaces, delimitações e uma proposta. In: BENINI, E \& OUTROS (orgs.) Gestão Pública e sociedade: fundamentos e políticas públicas de economia solidária. São Paulo: Outras Expressões, 2011.

DAGNINO, E.; TATAGIBA, L. Democracia, sociedade civil e participação. Chapecó: Argos, 2007.

DE LA TORRE A. Lo público y lo privado en el Estado Ecuatoriano: la Junta de Beneficiencia de Guayaquil; Quito: Abya Ayala, 2000.

DEMOS. Gobernar la Globalización. La política de la inclusión: el cambio de responsabilidad compartida (Cumbre Regional para el Desarrollo Politico y los principios democráticos. Brasilia, jul. 1997). México, Proyecto DEMOS- UNESCO.

DE OLIVEIRA, F. Hegemonia as avessas, Revista Piauí. n 6, São Paulo, 2007.

DI STEFANO, R e outros. De las cofradias a las organizaciones de la socieidad civil. Historia de la Iniciativa asociativa en Argentina 1776 - 1990. Argentina: Gadis, 2007.

DUSCHATZKY, S.; REDONDO, P. Las marcas del plan social educativo o los indicios de ruptura de las políticas públicas. In: DUSCHATZKY, S (orgs.) Tutelados y 
Asistidos. Programas Sociales, políticas públicas y subjetividade. Buenos Aires, Paidos, 2000.

EID, F. Descentralização do Estado, Economia Solidária e Políticas Públicas: construção da cidadania ou reprodução histórica do assistencialismo? Anais do XI FIEALC - Federação Internacional de Estudos sobre América Latina e Caribe, Osaka, Japão. In: Educação e Sócio-Economia Solidária - Paradigmas de Conhecimentos e de Sociedades, 1, Cácares: UNEMAT Editora, 2004, v1, p. 156172.

ENGELS, F. A situação da classe trabalhadora na Inglaterra. São Paulo: Global, 1986.

ESPING-ANDERSEN, G. As Três Economias Políticas do Welfare State, Revista Lua Nova, n 24, set. 1991.

ESPING - ANDERSEN, G. Los tres mundos del Estado de Bienestar. Valencia: Editorial Alfons el Magnanim, 1993.

EQUADOR. Governo Equatoriano. Decreto de Creación del IEPS de 2009. Disponível em: <www.economiasolidaria.org>. Acesso em: mar/2011.

EQUADOR. MIES - Ministerio de coordinacion de desarrollo social, - IEPS. Proyecto de Ley de la Economia Popular y Solidária. Disponível em: <www.mies.gov.ec>. Acesso em: mar/ 2011.

FARIA, C. F. Estado e organizações da sociedade civil no Brasil contemporâneo: construindo uma sinergia positiva?. Revista Sociologia Política. Curitiba, v 18, n 36, 2010. Disponível em: <http://www.scielo.br/scielo.php?script=sci_arttext\&pid=S0104$44782010000200012 \&$ lng=en\&nrm=iso>. Acesso em: jul/ 2011.

FARIA, M. S de. Autogestão, cooperativa, economia solidária: avatares do trabalho e do capital. Florianópolis, UFSC, Tese de Doutorado em Sociologia Política. 2005.

FARIA, M. S de....Se a coisa é por aí, que autogestão é essa? Um estudo da experiência "autogestionária" dos trabalhadores da Makerli Calçados. Florianópolis, UFSC, Dissertação de Mestrado em Administração. 1997.

FARIA, M. S de; SANCHEZ, F. A economia solidária no Governo Federal: intersetorialidade, transversalidade e cooperação internacional. In: BENINI \& OUTROS (orgs.) Gestão Pública e sociedade: fundamentos e políticas públicas de economia solidária. São Paulo: Outras Expressões, 2011. 
FBES. Carta de princípios. 2003. Disponível em: <www.fbes.org.br>. Acesso em jan/2011.

FILGUEIRA, F. Ciudadanía y Políticas sociales Latino-americanas. Costa Rica: FLACSO, 1998.

FILGUEIRA, F. El nuevo modelo de prestaciones sociales en América Latina: eficiencia, residualismo y ciudadanía estratificada. In: ROBERT, B. (editor). Ciudadanía y Política Social. San José Costa Rica: FLACSO, 1998b.

FILGUEIRAS, L. O neoliberalismo no Brasil: estrutura, dinâmica e ajuste do modelo econômico. In: BASUALDO, E. M.; ARCEO, E. Neoliberalismo y sectores dominantes. Tendencias globales y experiencias nacionales.. CLACSO, Buenos Aires, 2006. Disponível em:

<http://bibliotecavirtual.clacso.org.ar/ar/libros/grupos/basua/C05Filgueiras.pdf> Acesso em: jun/2010.

FIORI, J. L Estado do Bem-estar social: padrões e crises - Textos para DiscussãoUFRJ/IEI, n 340, 1995.

FONSECA, M. O Banco Mundial como referência para a justiça social no Terceiro Mundo: evidências do caso brasileiro. Revista de Educação, v 24.1, jan/jun, 1998.

FOUCAULT, M. Governamentalidade. In: Machado, R (ed.), Microfísica do poder. Rio de Janeiro: Graal, 1979.

FOUCAULT, M. O sujeito e o poder. In: DREYFUS, H; RABINOW, P. Michel Foucault. Uma trajetória filosófica: para além do estruturalismo e da hermenêutica. Rio de Janeiro: Forense Universitária, 1995.

FOUCAULT, M. O que é a crítica? Cadernos da FCC, v 9, n 1. Faculdade de Filosofia e Ciências, UNESP Marília, 2000.

FOUCAULT, M. Em defesa da sociedade. São Paulo: Martins Fontes, 2005.

FOUCAULT, M. Nascimento da biopolítica. São Paulo: Martins Fontes, 2008.

FOUCAULT, M. Segurança, território, população. São Paulo: Martins Fontes, 2008b.

FRANÇA FILHO, G. A problemática da economia solidária: um novo modo de gestão pública? Cadernos Ebape, FGV-RJ, v 2, n 1, mar, 2004.

FRANÇA FILHO, G. Políticas públicas de economia solidária no Brasil: características, desafios e vocação. In FRANÇA FILHO, G.; LAVILLE, J.; 
MEDEIROS, A.; MAGNEN, J. P. (Orgs.). Ação pública e economia solidária: uma perspectiva internacional. Porto Alegre/Salvador: Edufrgs-Edufba, 2006.

FRANÇA FILHO, G; SILVA Jr. Uma dinâmica associativa emblemática no nordeste brasileiro, In: FRANÇA FILHO, G.; LAVILLE, J.; MEDEIROS, A.; MAGNEN, J. P. (orgs.). Ação pública e economia solidária: uma perspectiva internacional. Porto Alegre/Salvador: Edufrgs-Edufba, 2006.

FRANÇA FILHO, G. C. Considerações sobre um marco teórico-analítico para a experiência dos Bancos Comunitários. Encontro Nacional de Pesquisadores em Gestão Social I, 23-25 de maio de 2007, Juazeiro do Norte, Ceará.

FRANCO, R. Los paradigmas de la política social en América Latina. Argentina: CEPAL, 1996.

FURTADO, C. Formação Econômica da América Latina. Rio de Janeiro: LIA, 1969.

FURTADO, C. O Mito do Desenvolvimento Econômico. Rio de Janeiro: Paz e Terra, 1995.

GAIGER, L. I. Os caminhos da economia solidária no Rio Grande do Sul. In: SINGER, P, SOUZA, A R de (orgs.) A economia Solidária no Brasil. São Paulo: Contexto, p. 267-86, 2000.

GAIGER, L. I. Sentido e possibilidades da economia solidária hoje, In: KRAYCHETE, G; LARA, F e COSTA, B. (orgs.). Economia dos setores populares: entre a realidade e a utopia, Petrópolis, RJ: Vozes, 2000b.

GAIGER, L. I. A economia solidária diante do modo de produção capitalista. Caderno CRH, Salvador, n. 39, p. 181-211, jul/dez 2003. Disponível em $<w w w . e c o s o l . o r g . b r>$. Acesso em: fev/2011.

GAIGER, L. I. Economía solidaria y capitalismo en la perspectiva de las transiciones históricas. In: CORAGGIO, J. L. (org.). La Economía Social desde la Periferia: contribuciones latino-americanas.. Colección de lecturas de economía social. Buenos Aires: UNGS-Altamira Ed, 2007.

GAIGER, L. I ; BESSON, M; LARA, F; SOMMER, I. A. Economia Solidária no RS: viabilidade e perspectivas. Cadernos Cedope, UNISINOS. Ano 10, n 15, 1999.

GAIVIZZO, S. B. Limites e possibilidades da economia solidária no contexto das transformações do mundo do trabalho: a experiência da incubadora de cooperativas populares da Universidade Católica de Pelotas. Dissertação de Mestrado. Porto Alegre, PUCRS, 2006. 
GARCIA, D. Bancos Comunitários de Desenvolvimento: um estudo sobre a implementação dos Bancos Comunitários ligados ao movimento de moradia no município de São Paulo. Dissertação de Mestrado. FGV. São Paulo, 2010.

GEREMEK, B. A piedade e a forca: história da miséria e da caridade na Europa. Lisboa: Terramar, 1986.

GIANNOTTI, V. História das Lutas dos Trabalhadores no Brasil. Rio de Janeiro: Muad, 2007.

GLENN, D. W. Relato de cuatro programas de banca comunal: mejores prácticas en América Latina. BID, 2003. Disponível em: <www.iadb.org> Acesso em: mar/2011

GÓMEZ GIL, C. Precauciones y cautelas en los microcréditos como instrumentos de desarrollo. Economistas sin Fronteras. Dossieres EsF. n 3, out/ 2011. Madrid.

GONZÁLEZ MANRIQUE, L. E. La inmigración transnacional latinoamericana. EI caso de Ecuador. Revista Ómnibus n 11, ano II, set/ 2006. Madrid. Disponível em: <http://www.omni-bus.com>. Acesso em: jan/2012.

GUERRA, P. Clubes de trueque: análisis socioeconòmico y jurídico, Montevideo: FCU, 2003.

GUERRA, P. Crisis y empresas alternativas en Uruguay: el caso de las cooperativas de produccion como emergentes de un sector solidario de la economia. UDELAR FCCSS- Departamento Sociologia, 1997. Disponível em: $<$ http://pabloguerra.tripod.com/Crisis.htm>. Acesso em: jan/2011.

HALL, M; SPALDINGD, H. La Clase Trabajadora Urbana y los Primeros Movimientos Obreros en América Latina. In: BETHELL, L (ed) 1991. Historia de América Latina, Tomo 7: América Latina: Economía y Sociedad, 1870-1930, Cambridge University Press, Barcelona: Editorial Crítica.

HERNÁNDEZ, V. La Patria vuelve: una posibilidad para construir nueva hegemonía. Una lectura al Gobierno de Rafael Correa en Ecuador. Revista Entre Voces. Grupo Democracia y Desarrollo Local, Ecuador, 2007.

HERRERA GÓMEZ, M; CASTÓN BOYER, P, Las políticas sociales en las sociedades complejas. Editorial Ariel, S.A, 2003.

HUMPHREY, J. Fazendo o "milagre": controle capitalista e luta operária na indústria automobilística brasileira. Petrópolis: Vozes, 1982.

HOBSBAWN, E. Historia del Siglo XX. Barcelona: Crítica, cap. XIV, 1995. 
HOLLIS, A; SWEETMAN, A. Microcredit: What can we learn from the past? In: World Development, Elsevier Science, v 26, n10, 1998.

IRIBARREN, C. ¿Ciudadanías Asistidas?: Discusión a partir de una Política concreta: El Ingreso Ciudadano. FCS-UDELAR. Montevideo, 2008.

IVO, A. B. L. Metamorfoses da questão democrática: governabilidade e pobreza. Buenos Aires: CLACSO, 2001.

KINGMAN, E. El imaginario de la pobreza y las políticas de ajuste en Ecuador. Revista Proposiciones n 34, Santiago de Chile, Ediciones Sur, 2002.

KLIKSBERG, B. Falências e Mitos do Desenvolvimento Social. São Paulo: Cortez, 2001.

KLIKSBERG, B; SOTTOLI, S. Cambios estructurales, situación social y dimensiones para el análisis y diseño de políticas sociales en América Latina. Papeles de población, out/dez 2002. n 34, p 9 - 43. Universidad Autónoma del Estado de México. Toluca, México.

KORNIS, G. A Crise do Estado de Bem-Estar: Problemas e Perspectivas da Proteção Social, Tese de Doutoramento, IEI/UFRJ, Mimeo, 1994.

KRIEKEN, R. V. A organização da alma: Elias e Foucault sobre a disciplina e o eu. Plural, Sociologia - USP. n 1, semestre. p. 153 - 180, 1996.

KROPOTKIN, P. El apoyo mutuo: un factor de la evolución. Madrid: Zero, 1970.

LEITE. M. A Economia Solidária e o Trabalho Associativo: Teorias e Realidades. Revista Brasileira de Ciências Sociais, v. 24, n 69, 2008.

LEÓN, M. Los beneficiarios del bono solidario ante la crisis. Documentos de trabajo del SIISE, n 10, Quito, 2000.

LEÓN, M. El 'buen vivir': objetivo y camino para otro modelo. 2008. Disponível em: <http://alainet.org/active/26638\&lang=es>. Acesso em: set/2011.

LICHTHEIM, G. Los orígenes del socialismo. Barcelona: Editorial Anagrama, 1968.

LOJKINE, J. O tabu da gestão: a cultura sindical entre contestação e proposição. Rio de Janeiro: DP\&A, 1999. 
LO VUOLO, R. La nueva oscuridad de la política social: del estado populista al neoconservador. Buenos Aires: CIEPP, 1998.

MAGILL, J. H; SWANSON, D. A. Diagnostico del sector microempresarial del Ecuador. Equador: Gemini, 1991.

MARCHÁN, C. Ecuador. Crisis, ajuste y política social en los años 80, Fundación Grupo Esquel Ecuador, UNICEF, 1992.

MARQUES, E. Notas críticas a literatura sobre Estado, políticas estatais e atores políticos. BIB - Boletim Bibliográfico de Ciências Sociais, n 43, p. 67- 102, 1997.

MARQUES, R.M; MENDES, Á. O social no governo Lula: a construção de um novo populismo em tempos de aplicação de uma agenda neoliberal. Revista Economia Política, São Paulo, v 26, n 1, mar/2006. Disponível em: <http://www.scielo.br/scielo.php?script=sci_arttext\&pid=S0101$31572006000100004 \&$ Ing=en\&nrm=iso>. Acesso em: set/2011.

MARTINEZ, A. Microcredito y pobreza en Venezuela: Un caso de estudio. Revista Mexicana de Ciencias Politicas y Sociales. Ano XL V III, n 198, 2006.

MARTINS, P. H.; WINOGRD, A.; SALLES, R. C. Regulamentação das microfinanças. Rio de Janeiro: BNDES, 2002.

MARX, K. El Capital. Fondo de Cultura Económica: Bogotá, 1952.

MARX, K. O Capital: crítica da economia política. Livro Primeiro. v I. São Paulo: Civilização Brasileira, 1992.

MARX, K. Manifesto de lançamento da Associação Internacional dos Trabalhadores, In: MARX, K.; ENGELS, F. Obras escolhidas. São Paulo: AlfaOmega, 1988.

MARX, K. O 18 de Brumário de Louis Bonaparte. Lisboa: Ed. Avante, 1982[1869.

MARX, K; ENGELS, F. O manifesto do Partido comunista. Moscou: Ed. Progresso, 1987[1872]

MATHEWS, J.T; HAKIM, P. Prólogo a "El disenso de Washington". Fondo Carnegie para la Paz Internacional y Diálogo Interamericano. Washington, 2002.

MEDEIROS, A; SCHWENGBER, A; SCHIOCHET, V. Políticas públicas de economia solidária: por um outro desenvolvimento. Recife: Editora Universitária UFPE, 2006.

MEDEIROS, A. As organizações internacionais e a cooperação técnica. In: 
MARCOVITCH, J (org.). Cooperação internacional: estratégia e gestão. São Paulo: USP, 1994.

MELO, M. A. Federalismo e política social: as vicissitudes da descentralização. In: MELO N. L; LEAL S. M. R (org) Relacão público - privado: do local global. Recife: Edufpe, 1997.

MENELEU NETO. Desemprego e luta de classes: As novas determinidades do conceito marxista de exército industrial de reserva. In: TEIXEIRA, F.J. S. DE OLIVEIRA, M. A. Neoliberalismo e Reestruturação Produtiva: As novas determinações do mundo do trabalho. São Paulo: Ed.Cortez, 1998.

MENEZES, M M; CROCCO, M A. Sistemas de moeda local: uma investigação sobre seus potenciais a partir do caso do Banco Bem em Vitória/ES. Economia \& Sociedade, v. 18, n. 2 (36), pp. 371-398, ago/2009.

MELTZER, A; CHRISTIE, S. Anarquismo v lucha de clases, Buenos Aires, 1970.

MIDAGLIA, C. Reforma del Estado: un análisis alternativo. Revista Fronteras $n 1$. Departamento de Trabajo Social-Facultad de Ciencias Sociales- Universidad de la República. Editorial FCU. Montevideo, Uruguay, 1995.

MIDAGLIA, C. Alternativas de protección a la infancia carenciada. La peculiar convivencia de lo público y privado en el Uruguay. Colección Becas de CLACSO Asdi. Buenos Aires: CLACSO, 2000.

MIDAGLIA, C. La ciudadanía social en debate. In: GIOSCIA, L (comp), Ciudadanía en Tránsito. Perfiles para el debate. Montevideo: Editorial Banda Oriental. 2001.

MIDAGLIA, C. La izquierda y las Políticas Sociales. In: Las claves del cambio. Ciclo electoral y nuevo gobierno 2004/2005. Montevideo: Banda Oriental, 2005.

MIDAGLIA, C.; ANTIA, F. La izquierda en el gobierno: ¿cambio o continuidad en las políticas de bienestar social?. Revista Uruguaya de Ciencia Política, n 16. Montevideo: ICP/FCS, 2007.

MILK, R. Movimiento obrero ecuatoriano: el desafío de la integración. Pontificia Universidad Católica del Ecuador Instituto de Investigaciones Económicas. Quito: Abya-Yala Editing, 1997.

MORAES FILHO, E de. O problema do Sindicato Único no Brasil. São Paulo: AlfaOmega, 1978. 
MORENO, J. A. Sombras en las microfinanzas. In: Economistas sin Fronteras. Dossieres EsF. n 3, out/ 2011. Madrid.

MUHAMMAD, Y. Hacia un Mundo sin Pobreza. Banco Gramen, 1997.

MUHAMMAD, Y. O Banqueiro dos pobres. Sao Paulo: Editora Atica, 2001.

NAVARRO, J.C. Las ONGs y la prestación de servicios sociales en América Latina: el aprendizaje ha comenzado, In: Lo público no estatal en la reforma del Estado. BRESSER PEREIRA \& CUNILL (editores). Buenos Aires: CLAD PAIDOS, 1998.

NETO II, J J. M. Entrevista concedida ao Museu da Pessoa. Museu da Pessoa, São Paulo, 2008. Disponível em:

$<$ http://www.museudapessoa.net/MuseuVirtual/hmdepoente/depoimentoDepoente.do ?a ction=ver\&idDepoenteHome=11204>. Acesso em: ago/2010.

NETO II, J J. M; MAGALHÃES, S. O Poder do circulante local. A moeda social no Conjunto Palmeira. Fortaleza, 2005.

NETO II, J J. M; MAGALHÃES, S (orgs). Bairros pobres - ricas soluções: Banco Palmas ponto a ponto. Fortaleza: Lamparina, 2008.

NETO II, J. J. M; MAGALHÃES, S. Banco comunitário e cooperativa de crédito: uma relação necessária para potencializar as finanças da periferia. Fortaleza: Expressão Gráfica, 2005.

NETO II, J J. M; MAGALHÃES, S. Bancos Comunitários de Desenvolvimento. Uma rede sobre controle da comunidade, 2006.

NOGUEIRA BATISTA Jr, P. O Consenso de Washington: A visão neoliberal dos problemas latino-americanos. 1994.1 Disponível em: <tarcisiodezena.sites.uol.com.br/apostila/conswash.htm>. Aceso em: dez/ 2010

NOGUEIRA, M. A. Um Estado para a sociedade civil: temas éticos e políticos para a gestão democrática. São Paulo: Cortez, 2004.

NORONHA, E. A explosão das greves na década de 80, In: BOITO JR. (org.), O sindicalismo brasileiro nos anos 80, São Paulo, Paz e Terra, 1991.

NORONHA, E. O modelo legislado de relações de trabalho e seus espaços normativos. Tese de doutorado, São Paulo, Universidade de São Paulo, 1998.

NOVAES, H. T. Os Simões Bacamarte da Economia Solidária. Campinas: Incubadora Tecnológica de Cooperativas Populares. 2004. Disponível em: 
$<$ http://www.itcp.unicamp.br>. Acesso em ago/2011.

NOVAES, H.T Algumas notas sobre a concepção marxista do Estado capitalista no século XX. In: BENINI, E \& OUTROS (orgs). Gestão Pública e sociedade: fundamentos e políticas públicas de economia solidária. São Paulo: Outras Expressões, 2011.

NOVELLI, J. M. N. A questão da continuidade da política macroeconômica entre o governo Cardoso e Lula (1995-2006). Rev. Sociol. Polit., Curitiba, v 18, n 36, Jun/2010. Disponível em http://www.scielo.br/scielo.php?script=sci_arttext\&pid=S0104$44782010000200014 \&$ Ing=en\&nrm=iso. Acesso em: set/2011.

NUNES, C. M. A. Tese de doutorado: Mudanças empresariais no Brasil Contemporáneo: O investimento social privado na saúde é uma nova forma de solidariedade?. Universidade Federal de Rio de Janeiro, 2006. Disponível em: <teses.ufrj.br/IPPUR_D/MariaAliceNunesCosta.pdf>. Acesso em: fev/ 2011

O'DONNELL, G. ¿Democracia Delegativa? Cuadernos del Claeh, n 61, Montevideo, 2da. Serie, ano 17/1, p. 5-20, 1992.

O'DONNELL, G. Acerca del Estado, la democratización y algunos problemas conceptuales. Una perspectiva latino-americana con referencias a países postcomunistas. In: Desarrollo Económico v 33, n 130, p 125 a 159, 1993.

OFFE, C. Contradicciones en el Estado de Bienestar. Madrid, Alianza, 1990.

OLIVEIRA, J. A. de A; TEIXEIRA, S. M. F. (Im)previdência social: 60 anos da história da previdência no Brasil. Petrópolis: Vozes; 1985.

OLIVEIRA, D; ROSAR M (orgs.) Política e Gestão da Educação. Belo Horizonte: Autentica, 2002.

PAOLI, M. C. Empresas e responsabilidade social: os enredamentos da cidadania no Brasil. In: SANTOS, B. S. (org.) Democratizar a democracia: os caminhos da democracia participativa. Rio de Janeiro: Civilização Brasileira, 2002.

PAREDES, P. El movimiento obrero en el Ecuador. La Internacional Sindical Roja 1, p 76-81, 1928.

PARETO, V. As Elites e o uso da força na Sociedade. Trad. Rangel, A. In: SOUZA, A de (org). Sociologia política. Rio de Janeiro, Zahar, 1966. 
PASIN, J. A. B.; BORGES, L. F. X. A nova definição de parceria público-privada e sua aplicabilidade na gestão de infraestrutura pública. Revista do BNDES. Rio de Janeiro, v 10, n 20, p. 173-196, 1993.

PATEO, F.; FORTETE, K. Desafios e potenciais da economia solidária como estratégia de geração de trabalho emancipado na América do Sul. Anais de Congresso, Fomerco, Rio de Janeiro, 2011.

PAUSELLI, E.; VILLARRAGA, J. Microfinanzas Vinculadas al Desarrollo de Población Pobre y Excluida: Otra Visión. Reflexiones para que las microfinanzas contribuyan efectivamente al desarrollo de Nuestra América. Buenos Aires: Documento Organización Poleas, 2006.

PEREIRA, P. La política social en el contexto de la seguridad social y del Welfare State: la particularidad de la asistencia social. In MONTAÑO, C; BORGIANNI, E. La política social hoy.. São Paulo: Editorial Cortez, 2000.

PINHEIRO, V. C. Modelos de desenvolvimento e políticas sociais na América Latina em uma perspectiva histórica. In: Planejamento e Políticas Públicas, n.12, jun./dez. p. 63-88, 1995.

PINTO, J. R. Economia solidária: de volta à arte da associação. Porto Alegre: UFRGS, 2006.

PINTO, C. R. J. A sociedade civil "institucionalizada". Política e Sociedade, Florianópolis, $\quad \mathrm{V}$ 1, $\mathrm{n} \quad 5$, p. 101-117, 2004. Disponível em: <http://www.periodicos.ufsc.br/index.php/politica/article/viewFile/1981/1730>. Acesso em: jun/ 2011.

POLANYI, K. La gran transformación. Crítica del liberalismo económico. Apresentação e tradução: Várela, J; Álvarez-Uría, F. Las Ediciones de La Piqueta: Madrid, 1989.

POULANTZAS, N. O Estado, o poder e o socialismo. Rio de Janeiro: Graal, 1985.

POULANTZAS, N. Poder político e classes sociais. São Paulo: Martins Fontes, 1986.

PRAXEDES, S. Políticas Públicas de economia solidária: novas práticas, novas metodologias. In: Mercado de trabalho, Brasília. IPEA, p. 57 a 62, 2009.

PREBISCH, R. Dinâmica do Desenvolvimento latino-americano. CEPAL. Rio de Janeiro/São Paulo: Fundo de Cultura, 1968. 
PUELLO-SOCARRÁS J. F. Del homo œconomicus al homo redemptoris: Emprendimiento y Nuevo Neoliberalismo. Revista Otra Economía, v IV, n 6, 1er semestre/ 2010. Disponível em: <http://www.riless.org/otraeconomia>. Acesso em nov/2011.

RAMA, C; CAPPELLETTI, A (eds.) El anarquismo en América Latina. Venezuela: Biblioteca Ayacucho, 1990.

ROSERO, F; REGALADO, F. Enfoques, formas de producción y elementos de política de Estado de la economía popular solidaria en Ecuador. SUBSECRETARÍA DE ECONOMÍA SOCIAL SOLIDARIA, MINISTERIO DE INCLUSIÓN ECONÓMICA Y SOCIAL CENTRAL ECUATORIANA DE SERVICIOS AGRÍCOLAS INTERCOOPERACIÓN. Proyecto poder. Quito, 2008.

QUIJANO, A . Otra noción de lo privado, otra noción de lo público. Revista de la CEPAL, n 35, Chile, 1988.

QUIJANO, A. Colonialidad del poder, eurocentrismo y América Latina, In: LANDER, E (comp.) La colonialidad del saber: eurocentrismo y ciencias sociales. Perspectivas Latino-americanas. Buenos Aires: CLACSO, Consejo Latino-americano de Ciencias Sociales, 2000.

QUIJANO, A. Colonialidad del poder, globalización y democracia. In: Tendencias básicas de nuestra época: globalización y democracia. Caracas: Instituto de Altos Estudios Diplomáticos Pedro Gual (Ed.), 2001.

QUIJANO, A. ¿Sistemas alternativos de producción? In: CORAGGIO, J L (Org), La economía social desde la periferia. Contribuciones latino-americanas, Universidad Nacional de General Sarmiento-Altamira, Buenos Aires, 2007.

QUIJANO, A. "Solidaridad" y capitalismo colonial/moderno. Otra Economía - Revista Latino-americana de Economía Social y Solidaria, n 2, 2008. Disponível em $<w w w . e c o n o m i a s o l i d a r i a . o r g>$. Acesso em: nov/2010.

QUIJANO, A. Sistemas alternativos de produção?, In: SOUZA SANTOS (org.), Produzir para viver, São Paulo: Civilização Brasileira, 2002.

ROUQUIÉ, A. América Latina: introducción al Extremo Occidente. México: Siglo XXI, 1994.

RUTHERFORD, S. Los Pobres y su Dinero. México: Colmena Milenaria / Unión de Esfuerzos para el Campo AC, 2002. 
SALAZAR, G. De la participación ciudadana: capital social constante y capital variable (Explorando senderos transliberais), In: Proposiciones, Santiago do Chile, $\mathrm{n}$ 28, 1998.

SANTOS, B. S. (org.) Produzir para viver: os caminhos da produção não capitalista. Rio de Janeiro: Civilização Brasileira, 2002.

SCHIOCHET V. Políticas Públicas de Economia Solidaria- breve trajetória e desafios. In: BENINI, E \& OUTROS (orgs.). Gestão Pública e sociedade: fundamentos e políticas públicas de economia solidária. São Paulo: Outras Expressões, 2011.

SEINTENFUS, R; VENTURA, D. Introdução ao Direito Internacional Público. Porto Alegre: Livraria do Advogado Editora, 1999.

SENAES/MTE. Atlas da Economia Solidária no Brasil 2005. Secretaria Nacional de Economia Solidária, Ministério do Trabalho e Emprego. Brasília, 2005.

SENAES/MTE. Sistema Nacional de Informações em Economia Solidária (SIES): Guia de orientações e procedimentos do SIES 2009/2010.

SERRANO, C. La política social en la globalización. Programas de protección en América Latina. Serie Mujer y Desarrollo n. 70. Santiago, Chile: CEPAL, 2005.

SIERRA, E. Ecuador, la política social en el marco de las políticas de ajuste y los câmbios neoliberales, CORDES, Quito, 1994.

SILVA JÚNIOR, J. T. Os bancos comunitários como instrumento de desenvolvimento socioeconômico de territórios: investigando as singularidades destas experiências de finanças solidárias. In: Encontro Nacional da Anpad, XXXI, 22-26 de set/2007, Rio de Janeiro, 2007.

SINGER, P. Uma utopia militante: repensando o socialismo. Petrópolis: Vozes, 1998.

SINGER, P. Economia dos setores populares: propostas e desafios, In: KRAYCHETE, G; LARA, F \& COSTA, B (orgs.), Economia dos setores populares: entre a realidade e a utopia, Petrópolis, RJ: Vozes, 2000a.

SINGER, P. Economia solidária: um modo de produção e distribuição, In: SINGER, $\mathrm{P} \&$ SOUZA A. de S (orgs.). A economia solidária no Brasil. São Paulo: Contexto, $2000 b$.

SINGER, P. A Economia Solidária. Td Teoria e Debate, 47 fev/mar/abr, 2001. 
SINGER, P. A recente ressurreição da economia solidária no Brasil. In: SANTOS, B. De S (org). Produzir para viver. Os caminhos da produção não capitalista. Rio de Janeiro: Civilização Brasileira, 2002.

SINGER, P. Introdução à Economia Solidária. São Paulo: Fundação Perseu Abramo, 2002.

SINGER, P. A experiência brasileira da SENAES, In: FRANÇA FILHO \& OUTROS, Ação pública e economia solidária: uma perspectiva internacional, Porto Alegre: UFRGS, 2006.

SINGER, P. Economía Solidaria. Un modo de producción y distribución. In: CORAGGIO, J. L (org.). La Economía Social desde la Periferia: contribuciones latino-americanas. Buenos Aires: UNGS-Altamira, 2007.

SINGER, P.; SOUZA, A. R. (orgs.). A economia solidária no Brasil: a autogestão como resposta ao desemprego. São Paulo: Contexto, 2000.

SIQUEIRA NETO. Flexibilização, desregulamentação e o direito do trabalho no Brasil, In C. OLIVEIRA \& J. MATTOSO, Crise e trabalho no Brasil, São Paulo, Scritta, 1996.

STAHL, K. Política Social en América Latina. La privatización de la crisis. Revista Nueva Sociedad, n 131, Caracas, 1994.

TEIXEIRA, A. C. C. A atuação das organizações não-governamentais: entre o Estado e o conjunto da sociedade. In: DAGNINO, E. (org.) Sociedade civil e espaços públicos no Brasil. Rio de Janeiro: Paz e Terra, 2002.

THEODORO, M.; DELGADO, G. Política social: universalização ou focalização subsídios para o debate. Políticas sociais: acompanhamento e análise. Brasília, Ipea, DF, n.7, ago, 2003.

THOMPSON, E. P. A formação da classe operária inglesa. III - A força dos trabalhadores. Rio de Janeiro: Paz e Terra, 1989.

TORRES, L. La Microempresa en el Ecuador. Quito, Equador, 2000.

TORRES, L. El Crédito Microempresarial en el Ecuador. 1ed. Quito, Equador, 2000.

VALDIVIA, M. Acerca de la dinámica de los bancos comunales y la sostenibilidad de las instituciones financieras que las promueven: Aprendiendo de la experiencia de FINCA- Perú. 2004. 
VALLEJO BAEZ, C. Elementos del sindicalismo, Quito, 1967.

VÁSCONEZ, A. La política social en Ecuador 80-90: sentidos, contextos y resultados, Serie Política Sociales de la CEPAL 82, Chile, 2003.

VÁSCONEZ A; VOS R. \& OUTROS. Política Social y Tendencias en el Gasto Social: Ecuador 1970-2002, Eficiencia y Equidad Social. Informe n.1, SIISE, Quito, 2003.

VÁSCONEZ, A.; CÓRDOBA, R.; MUÑOZ, P. La construcción de las políticas sociales en Ecuador durante los años ochenta y noventa: sentidos, contextos y resultados, Santiago de Chile: CEPAL, 2005.

VILLATORO, P. Programas de reducción de la pobreza en América Latina. Un análisis de cinco experiencias, Santiago de Chile: CEPAL, 2004.

VIÑAS, D. Anarquistas en América Latina, México: Katan, 1983.

Vío GROSSI, F. (ed.) Primero la gente. ONG, Estado y cooperación internacional en el tercer Mundo. Santiago de Chile, Consejo de educación de Adultos de América Latina- CEAA, 1989.

WILLIAMSON, J. What Washington Means by Policy Reform. In: Latin American Adjustment: How Much Has Happened?, Washington: Institute for International Economics, 1990.

ZIBECHI, R. Políticas sociales, gobiernos progresistas y movimientos antisistémicos. Revista Otra Economía, v IV, n 6, 1er semestre/ 2010. Disponível em: $<$ http://www.riless.org/otraeconomia>. Acesso em nov/2011. 